CAMILA FRANCHITTO CECARELLI

\title{
PROVA ILÍCITA POR DERIVAÇÃO NO DIREITO PROCESSUAL PENAL BRASILEIRO
}

Dissertação apresentada ao curso de PósGraduação da Faculdade de Direito da Universidade de São Paulo, área de concentração em Direito Processual, como requisito parcial à obtenção do título de Mestre em Direito.

Orientador: Professor Doutor José Raul Gavião de Almeida.

FACULDADE DE DIREITO DA UNIVERSIDADE DE SÃO PAULO

SÃO PAULO

2011 
Banca examinadora 


\section{AGRADECIMENTOS}

A concretização desta dissertação não seria possível não fosse o apoio de diversas pessoas a quem, de forma singela, demonstro minha eterna gratidão nesse espaço.

Primeiramente agradeço a Deus, pelo dom da vida e pela graça de estudar (novamente) na melhor Faculdade de Direito da América Latina.

De forma muito especial agradeço ao Professor Doutor José Raul Gavião de Almeida que me concedeu a honra de ser sua orientanda, conferindo-me essa valiosa oportunidade, ao depositar em sua aluna, recém egressa da graduação, a confiança necessária para a realização deste trabalho.

Agradecimentos especiais são devidos também ao Professor Titular Antonio Scarance Fernandes e ao Professor Associado Maurício Zanoide de Moraes pelas aulas enriquecedoras ministradas no Curso de Pós Graduação.

Devo agradecer também às importantes observações feitas pelo Professor Titular Antonio Scarance Fernandes e pelo Professor Doutor Gustavo Henrique Righi Ivahy Badaró durante o meu Exame de Qualificação. Ainda a estes dois ilustres professores agradeço, ao primeiro pela leitura do meu trabalho e considerações feitas e ao segundo pelas obras bibliográficas que me foram disponibilizadas para consulta.

Agradeço ainda aos amigos que colaboraram com a leitura deste trabalho e com o fornecimento de material bibliográfico para estudo.

Aos colegas do Curso de Pós Graduação pelas dicas e conversas sempre muito interessantes.

À minha família, pela alegria do seu convívio e pelo apoio incondicional neste e em tantos outros projetos.

Muito obrigada! 


\section{RESUMO}

O presente trabalho versa sobre a ilicitude probatória por derivação (também chamada de teoria dos frutos da árvore envenenada) e suas mitigações no sistema processual penal brasileiro.

A fim de viabilizar essa abordagem, contudo, é necessário rever alguns temas que se colocam como antecedentes lógicos à análise do assunto principal.

Nesse sentido, aborda-se a relação existente entre busca da verdade, processo penal e provas. O direito à prova é estudado mediante a apresentação de distintos conceitos que lhe são atribuíveis.

A temática da prova ilícita se insere nas limitações impostas ao exercício do direito à prova. Nesse ponto, é feita a distinção entre provas ilegais, provas ilícitas e provas ilegítimas.

Em seguida faz-se uma breve incursão na temática da ilicitude da prova penal ao redor do globo, a fim de verificar as principais influências estrangeiras sobre o regramento interno. De forma sucinta, aborda-se o tratamento dispensado à prova ilícita, e em especial à ilicitude derivada, no ordenamento dos Estados Unidos da América, na Alemanha, em Portugal, na Espanha, na Itália e na Inglaterra.

Posteriormente trata-se da prova ilícita no Brasil, iniciando-se com uma abordagem histórica da evolução legislativa do tema, para ser feita, a seguir, uma análise detalhada do dispositivo constitucional que veda no sistema pátrio a admissibilidade das provas ilícitas nos autos do processo. Passa-se então a analisar a disciplina legal infraconstitucional das provas ilícitas e as novidades inseridas pela Lei n ${ }^{\circ} 11.690 / 08$ acerca da matéria no Código de Processo Penal vigente, bem como o tratamento dado ao tema no Projeto de Novo Código de Processo Penal.

Por fim, volta-se o objeto de estudo para as provas ilícitas por derivação no sistema processual penal brasileiro. Nesse ponto, são apresentados o conceito de ilicitude derivada e a evolução do tratamento dispensado ao tema internamente. 
A seguir é abordada a questão das atenuações à ilicitude por derivação, começando pela análise dos limites existentes à imposição de restrições legais ao quanto previsto no artigo $5^{\circ}$, inciso LVI, da Constituição Federal.

$\mathrm{Na}$ seqüência são estudadas as hipóteses de mitigação à ilicitude derivada inseridas no Código de Processo Penal de 1941 pela Lei n ${ }^{\circ}$ 11.690/08, fazendo-se a necessária confrontação com o quanto fixado constitucionalmente.

Por fim, aborda-se o tratamento conferido à ilicitude probatória por derivação no Projeto de Novo Código de Processo Penal.

Ao final são apresentadas as conclusões do trabalho. 


\section{RIASSUNTO}

Questa dissertazione discute la prova illecita per la derivazione (chiamata anche la teoria del frutto dell'albero velenoso) e la sua mitigazione nel processo penale brasiliano.

Al fine di facilitare questo approccio, tuttavia, è necessario rivedere alcuni questioni che sorgono come antecedenti logici per l'analisi del soggetto principale.

Di conseguenza, esploriamo il rapporto tra ricerca della verità, la procedura penale e le prove. La prova è studiata con la presentazione di diversi concetti che le sono attribuibili.

La questione della prova illecita si pone nei limiti imposti all'esercizio del diritto alla prova. A questo punto, viene fatta una distinzione tra elementi di prova illegale, prove illecite ed illegittime.

Poi facciamo una breve incursione nel merito di illiceità del materiale probatorio in tutto il mondo, per verificare le principali influenze straniere sul regramento interno. Brevemente, si discute il trattamento riservato alla prova illecita, e in particolare all'illiceità derivata, sull'ordinamento degli Stati Uniti, Germania, Portogallo, Spagna, Italia ed Inghilterra.

Più tardi si occupa della prova illecita in Brasile, a partire di un approccio storico degli sviluppi legislativi del tema, viene poi fatta una dettagliata analisi della norma costituzionale che vieta la utilizzabilità nel sistema brasiliano della prova illecita nel processo. Poi, si passa ad esaminare la disciplina giuridica fissata dalla legge sulle prove illecite e le innovazioni inserite da Legge 11.690/08 circa la questione nel Codice di Procedura Penale vigente, nonché il trattamento del tema nel Nuovo Progetto di Codice di Procedura Penale.

Infine, diventa l'oggetto di studio la derivazione della prova illecita nel sistema processuale penale brasiliano. A questo punto, si introduce il concetto di illiceità derivata e l'evoluzione del trattamento del problema internamente.

Qui di seguito, viene discussa la questione della mitigazione all'illiceità derivata, a partire di una analisi sui limiti esistenti in materia di imposizioni di restrizioni legali all'articolo $5^{\circ}$, comma LVI, della Costituizione Federale. 
Nella sequenza sono studati i casi di attenuazioni dell'illiceità derivata che sono inseriti nel Codice di Procedura Penale del 1941 da Legge 11.690/08, facendo i confronti necessari con quello costituzionalmente prescritto.

Infine, si discute il trattamento dato alla prova illecita per la derivazione dal Nuovo Progetto di Codice di Procedura Penale.

Le conclusioni della tesi sono riportate all finale. 


\section{SUMÁRIO}

Introdução

p. 10

1. Premissas teóricas e conceitos

p. 13

1.1. Considerações sobre verdade, processo penal e provas

p. 13

1.2. A superação da dicotomia entre verdade material $X$ verdade formal e a construção do conceito de verdade processual

p. 19

1.3. $\mathrm{O}$ direito à prova

p. 23

1.3.1. Objeto de prova e ônus da prova no processo penal brasileiro

p. 25

1.3.2. Definições doutrinárias em matéria de prova

p. 30

1.3.3. Provas ilegais, ilícitas e ilegítimas

p. 32

1.3.4. Limites ao direito à prova

p. 36

1.4. Eficiência e garantismo e as provas ilícitas

p. 41

1.5. Defeitos dos atos jurídicos. Distinções entre o regime das nulidades processuais e a inadmissibilidade de provas

p. 43

1.6. Correntes acerca da ilicitude probatória

p. 46

2. A prova ilícita no direito comparado

p. 49

2.1. Prova ilícita nos Estados Unidos

2.2. Prova ilícita na Alemanha

p. 61

2.3. Prova ilícita em Portugal

p. 69

2.4. Prova ilícita na Espanha

p. 74

2.5. Prova ilícita na Itália

p. 78

2.6. Prova ilícita na Inglaterra

p. 82

3. A disciplina da prova ilícita no Brasil

p. 88

3.1. Histórico e evolução

p. 88

3.2. Análise do artigo $5^{\circ}$, inciso LVI, da Constituição Federal

p. 92

3.2.1. Considerações prévias

p. 92

3.2.1.1. Regras e princípios

p. 93 
3.2.1.2. Proporcionalidade p. 98

$\begin{array}{ll}\text { 3.2.2. Natureza jurídica } & \text { p. } 103\end{array}$

3.2.3. Classificação p. 107

3.2.4. Alcance p. 111

3.3. Disciplina legal das provas ilícitas no Código de Processo Penal p. 114

3.3.1. Definição legal e interpretação p. 115

3.3.2. Desentranhamento e inutilização p. 120

3.3.3. Julgamento e imparcialidade p. 123

3.4. Projeto de Novo Código de Processo Penal e as provas ilícitas p. 125

$\begin{array}{ll}\text { 4. Provas ilícitas por derivação } & \text { p. } 128\end{array}$

$\begin{array}{ll}\text { 4.1. Conceito } & \text { p. } 128\end{array}$

4.2. Evolução p. 130

4.3. Mitigações à ilicitude por derivação p. 133

4.3.1. Limites à imposição de restrições legais p. 134

4.3.2. Análise das hipóteses trazidas pelo Código de Processo Penal p. 138

4.3.2.1. Fonte independente p. 139

4.3.2.2. Inexistência de nexo de causalidade entre as provas ilícitas e as provas secundárias p. 141

4.3.2.3. Descoberta inevitável p. 146

4.4. Projeto de Novo Código de Processo Penal e as provas ilícitas por derivação p. 153

$\begin{array}{ll}\text { Conclusões } & \text { p. } 155\end{array}$

$\begin{array}{ll}\text { Bibliografia } & \text { p. } 161\end{array}$

$\begin{array}{ll}\text { Outras referências } & \text { p. } 174\end{array}$ 


\section{INTRODUÇÃO}

O presente trabalho trata da temática das provas ilícitas e sua inadmissibilidade no ordenamento jurídico brasileiro. De forma particular versa acerca da questão da ilicitude por derivação, também chamada de teoria dos frutos da árvore envenenada e suas mitigações no sistema pátrio.

O tema da ilicitude por derivação é costumeiramente abordado pela doutrina nacional de maneira bastante sucinta, como mero acessório à temática da prova ilícita, inexistindo obras que tratem especificamente da questão.

Entretanto, a falta de cuidado comumente verificada na abordagem do tema não se traduz na irrelevância da matéria, mas ao revés, conduz à necessidade de elaboração de um estudo pormenorizado sobre as provas ilícitas por derivação no sistema processual penal brasileiro.

A importância da matéria é ressaltada, ademais, em face da constatação de estar o assunto na pauta das discussões travadas no Congresso Nacional.

De fato, o tema recentemente foi objeto da Lei $n^{\circ} 11.690 / 08$ e novamente é abordado no PLS n ${ }^{\circ}$ 156/09, aprovado em seu substitutivo em dezembro de 2010 no Plenário do Senado, seguindo para a Câmara dos Deputados.

Assim, não há que se perder de vista que o tema central objeto deste trabalho são as provas ilícitas por derivação e o tratamento a elas dispensado pelo ordenamento jurídico brasileiro. Contudo, com vistas a viabilizar essa abordagem é necessário revisitar alguns pontos que se colocam como antecedentes lógicos à boa análise do assunto principal do trabalho.

O tema se insere dentro de um ponto central no Direito Processual Penal: o estudo das provas. Logo, no primeiro capítulo serão desenvolvidas premissas teóricas e apresentados conceitos acerca da temática probatória imprescindíveis ao desenvolvimento do trabalho.

Nesse sentido, será abordada a relação existente entre busca da verdade, processo penal e provas, passando pela superação da dicotomia entre verdade material e 
verdade formal, até culminar no conceito de verdade processual, amplamente dominante nos dias de hoje.

O direito à prova será estudado mediante a apresentação de distintos conceitos que lhe são atribuíveis e outros à ela relacionados, sem a pretensão de esgotar o tema, mas com o intuito de impor rigor científico ao seu estudo, quais sejam: objeto de prova, ônus da prova, elemento de prova, resultado da prova, fonte de prova, meio de prova, meio de investigação de prova etc.

No que tange às limitações impostas ao exercício do direito à prova insere-se a temática da prova ilícita. Nesse ponto, será feita a sua distinção em relação às provas ilegais, também chamadas de provas vedadas ou proibidas, e também em relação às provas ilegítimas.

Ainda neste capítulo preliminar serão apresentadas as correntes preponderantes acerca da ilicitude probatória, além de ser feita uma breve abordagem acerca da eficiência e do garantismo em matéria de prova ilícita.

No segundo capítulo do trabalho será feita uma breve incursão na temática da ilicitude da prova penal ao redor do mundo, a fim de verificar as principais influências estrangeiras sobre o tratamento interno e melhor entender a opção legislativa pátria.

Será abordado de forma sucinta o tratamento dispensado à prova ilícita, e em especial à ilicitude derivada, no ordenamento dos Estados Unidos, na Alemanha, em Portugal, na Espanha, na Itália e na Inglaterra.

O capítulo seguinte será reservado para o tratamento da prova ilícita no Brasil. Inicia-se com uma abordagem histórica da evolução legislativa do tema internamente, para ser feita, a seguir, uma análise detalhada do dispositivo constitucional que veda no sistema brasileiro a admissibilidade das prova ilícitas nos autos do processo.

Com vistas a municiar de elementos seguros esta análise, classificação e alcance de proteção do quanto disposto no artigo $5^{\circ}$, inciso LVI, da Constituição Federal, fazse uma sucinta abordagem no trabalho acerca da distinção existente entre normas regras e normas princípios e sobre a proporcionalidade.

Em seguida passe-se a analisar a disciplina legal infraconstitucional das provas ilícitas e as novidades inseridas pela Lei $\mathrm{n}^{\mathrm{o}}$ 11.690/08 acerca da matéria no Código de Processo Penal vigente, bem como o tratamento conferido ao tema no Projeto de Novo Código de Processo Penal. 
O quarto capítulo do trabalho tem como objeto as provas ilícitas por derivação no sistema processual penal brasileiro. Nesse ponto, apresenta-se o conceito de ilicitude derivada e a evolução do tratamento dispensado ao tema pela legislação, doutrina e Jurisprudência pátrias.

A seguir é abordada a questão das mitigações à ilicitude por derivação, começando pela análise dos limites existentes à imposição de restrições legais ao quanto previsto no artigo $5^{\circ}$, inciso LVI, da Constituição Federal.

Na sequiência serão estudadas as hipóteses de atenuação à ilicitude derivada inseridas no Código de Processo Penal de 1941 pela Lei no 11.690/08, fazendo-se a necessária confrontação com o quanto fixado constitucionalmente.

Ao fim será destacado o tratamento dado ao tema pelo Projeto de Novo Código de Processo Penal, em trâmite no Congresso Nacional.

Superados esses pontos serão apresentadas as conclusões do trabalho. 


\section{PREMISSAS TEÓRICAS E CONCEITOS}

\subsection{Considerações sobre verdade, processo penal e provas}

A busca da verdade sempre foi uma questão intrigante e de grande relevo nos mais diversos ramos do saber.

Em razão disso, no movimento da História inúmeras teorias foram desenvolvidas no campo da Filosofia a esse respeito. Também numerosas são as classificações feitas por processualistas penais acerca dessas teorias filosóficas.

Antonio Magalhães Gomes Filho ${ }^{1}$ trata dos "céticos", dos subjetivistas e dos objetivistas. Segundo menciona, os primeiros negavam de forma categórica qualquer possibilidade de se obter um saber absoluto. Os subjetivistas, por sua vez, chamados também de psicológicos ou epistemológicos entendiam que a verdade seria um estado da mente. Por fim, os objetivistas viam a verdade como sendo uma relação de correspondência com os fatos.

Cleunice Aparecida Valentim Bastos Pitombo ${ }^{2}$ aborda as teorias da correspondência, da coerência, teoria pragmática e teoria semântica. Afirma ainda que alguns filósofos que se dedicaram ao estudo da verdade não podem ser encaixados em nenhuma dessas subdivisões pela especificidade de seu pensamento.

Conforme menciona, para a teoria correspondencialista uma proposição será verdadeira se houver correspondência entre ela e um fato. Já para a teoria da coerência tal proposição será dita verdadeira se for considerada coerente com um sistema de proposições. A teoria pragmática, por sua vez, entende que uma proposição somente será verdadeira a partir de sua efetiva utilidade. E a teoria da semântica atribui a definição de verdade ao uso de determinada linguagem.

\footnotetext{
${ }^{1}$ GOMES FILHO, Antonio Magalhães. Sobre o direito à prova no processo penal. 1995. 195 f. Tese (Livredocência do Departamento de Direito Processual) - Faculdade de Direito, Universidade de São Paulo, São Paulo, p. 35 .

2 PITOMBO, Cleunice Aparecida Valentim Bastos. Processo Penal: Prova e Verdade. 2003. 209. f. Tese (Doutorado em Direito) - Faculdade de Direito, Universidade de São Paulo, São Paulo, p. 71-95.
} 
Não é objeto deste trabalho fazer um estudo aprofundado sobre as correntes filosóficas acerca da verdade. Entretanto, não se pode deixar de mencionar que também no âmbito do processo penal, a busca da verdade se mostra de primordial relevância ${ }^{3}$.

A principal função do Direito Processual Penal consiste em viabilizar a aplicação da lei penal ao caso, após tomar curso o devido processo legal ${ }^{4}$. Ou seja, é no curso do processo penal que se possibilita às partes (acusação e defesa) trazer suas versões sobre os fatos ocorridos, a partir do exercício do direito à prova, antes da concretização da lei penal no caso sub judice.

O direito à prova se mostra crucial para a efetivação da garantia de um processo devido e justo, juntamente com outras garantias constitucionais e processuais penais, como a paridade de armas entre acusação e defesa, a imparcialidade judicial, a ampla defesa, o contraditório, a motivação obrigatória das decisões judiciais, a celeridade processual etc.

Só haverá a possibilidade de se fazer justiça no caso concreto se as partes tiverem assegurado o direito de serem ouvidas pelo órgão jurisdicional competente, fazendo afirmações e comprovando o quanto alegado, a partir de todos os meios de prova em direito admitidos.

De fato, para que se obtenha uma correta aplicação do direito material ao caso concreto é necessário buscar, por todos os meios em direito admitidos, a "verdade dos fatos" trazidos à análise judicial. Há que se perquirir a mais fiel reprodução possível dos fatos ocorridos, narrados nos autos do processo para serem levados a julgamento. Essa "verdade dos fatos" será traduzida para o processo a partir dos elementos de prova insertos nos autos, ou seja, a partir do efetivo exercício do direito à prova pelas partes.

\footnotetext{
${ }^{3}$ Predomina o entendimento de que a teoria acerca da verdade melhor adaptável à realidade processual é a da verdade como correspondência. Nesse sentido vide: TARUFFO, Michele. La prueba de los hechos. Tradução de Jordi Ferrer Beltrán. Madrid: Editorial Trotta, 2002, p. 170 ss.

${ }^{4}$ Outros essenciais escopos do processo são a busca da justiça e a pacificação social. Na Exposição de Motivos do Código de Processo Penal Português, no item 8 estão elencadas algumas das principais finalidades do Processo Penal: realização de justiça, tutela de bens jurídicos, estabilização das normas e obtenção de paz jurídica para os cidadãos. DINAMARCO, Cândido Rangel. Instituições de Direito Processual Civil. 4. ed. São Paulo: Malheiros Editores, 2004. v. I, p. 125-137, versando acerca dos escopos do processo civil, aponta as seguintes finalidades processuais: pacificação social e educação e respeito para os direitos alheios e o exercício dos direitos próprios pelos indivíduos, que seriam os escopos sociais; determinação da estabilidade das instituições políticas e participação dos cidadãos na vida e no destino do Estado, compreendendo os escopos políticos; e o escopo jurídico, identificado pela justa composição da lide ou pela atuação da vontade concreta do direito, conforme a corrente axiológica adotada.
} 
Logo, percebe-se que o direito à prova há que ser o mais amplo possível, pois é a partir dele que se possibilita a realização do grande escopo do Direito: a efetivação de Justiça no caso concreto.

Por certo, a busca da verdade, entendida como meio apto a fomentar a boa aplicação do direito e a concretização de uma decisão justa, em conjunto com o respeito aos direitos individuais, deve ser o norte a guiar o processo penal.

Contudo é preciso notar que, conforme a visão adotada sobre a função da prova, diferirá o entendimento acerca da busca da verdade no curso do processo ${ }^{5}$.

De fato, podem ser destacados três grupos de posicionamentos principais.

Um primeiro entendimento rechaça, em absoluto, a idéia de verdade no processo penal. Defende esta teoria que epistemologicamente, ideologicamente ou por outros motivos, seria impossível considerar que a verdade dos fatos postos sub judice fosse estabelecida no curso do processo de um modo racional. Assim, o processo não poderia e sequer deveria orientar-se pela determinação da verdade. Conforme tal entendimento, a prova teria uma função meramente ritual, com vistas a fazer crer que os procedimentos penais são racionalmente determinados e conduzem à justiça das decisões.

Antonio Magalhães Gomes Filho a esse respeito chega a afirmar que "a difundida afirmação segundo a qual a função da prova é a de estabelecer a verdade dos fatos, antes de representar uma conclusão fundada na natureza dos procedimentos probatórios, configura uma vinculação de caráter persuasivo, através da qual a confusão entre elementos descritivos e emotivos é empregada com o fim de obter a adesão a certo ponto de vista, no caso a idéia de que as decisões judiciais, fundadas que são em provas, são verdadeiras e, por isso, justas". 6

Michele Taruffo ${ }^{7}$ aponta que, de acordo com esse primeiro entendimento, as provas serviriam para forçar a crença de que o processo penal determina a verdade dos fatos. Segundo tal posicionamento, ainda que isso não ocorra na realidade, seria útil que os cidadãos acreditassem nessa tese. Ademais, até porque a indigitada verdade não pode ser obtida na realidade seria preciso reforçar essa crença nos destinatários do sistema judicial.

\footnotetext{
${ }^{5}$ Conforme TARUFFO, Michele. La prueba de los hechos, p. 80-87.

${ }^{6}$ GOMES FILHO, Antonio Magalhães. Sobre o direito à prova no processo penal, p. 35 .

${ }^{7}$ La prueba de los hechos, p. 81.
} 
Um segundo posicionamento considera que a prova tenha uma função predominantemente persuasiva no âmbito processual ${ }^{8}$. Considera também ser o escopo maior do processo a pacificação social, sendo que, desse modo, a busca da verdade poderia surgir como um obstáculo a mais rápida consecução do seu objetivo, qual seja: o de eliminar controvérsias 9 .

Assim, segundo esta visão, a prova passa a ter uma função predominantemente persuasiva e não de busca de conhecimento dos fatos narrados nos autos do processo. Não se pretende apurar o que de fato ocorreu, mas obter uma versão verossímil, que corresponda à normalidade de um comportamento ou evento ${ }^{10}$, capaz de convencer e solucionar o conflito jurídico. As provas são utilizadas pelas partes unicamente para dar suporte à sua versão dos fatos. Não é a verdade um elemento fundante do processo.

A prova não serve para determinar a verdade ou falsidade sobre o enunciado que se faz sobre um fato juridicamente relevante, mas para persuadir o magistrado sobre a plausibilidade ou não daquele enunciado fático ${ }^{11}$. Não é preciso provar o que de fato ocorreu desde que a prova seja crível e demonstre algo factível, capaz de convencer.

Antonio Magalhães Gomes Filho ${ }^{12}$ criticando esse posicionamento e filiando-se a terceira corrente a seguir apresentada, adverte que a idéia de verossimilhança não se aplica ao juízo criminal, uma vez que seria inimaginável a justificação de uma decisão penal resultante de um convencimento superficial, fundamentado tão só na aparência de verdade. Segundo o autor é a busca da verdade processual que legitima a atividade jurisdicional penal ${ }^{13}$.

\footnotetext{
${ }^{8}$ Explanando tal teoria sem a ele aderir TARUFFO, Michele. La prueba de los hechos, p. 349 ss. Em sentido contrário, adotando a teoria da função persuasiva da prova vide JÚNIOR, Aury Lopes. Direito Processual Penal e sua Conformidade Constitucional. 5. ed. Rio de Janeiro: Editora Lumen Juris, 2010, v. I, p. 559-560. O autor posiciona-se pela coexistência das duas primeiras correntes expostas, às quais adere, indicando que seriam complementares. Por outro lado, critica de forma veemente os autores que se orientam segundo a terceira vertente e a busca da verdade no processo penal. $\mathrm{O}$ autor defende abertamente uma postura cética em relação à verdade no direito processual penal, negando completamente a obtenção da verdade como função do processo ou adjetivo da sentença.

${ }^{9}$ TARUFFO, Michele. Consideraciones sobre prueba y verdad. Derechos y Libertades: Revista del Instituto Bartolomé de las Casas, Madrid, ano VII, n. 11, jan./dez. 2002, p. 110.

${ }^{10}$ TARUFFO, Michele. La semplice verità: Il giudice e la construzione dei fatti. Roma: Editori Laterza, 2009, p. 88.

${ }^{11}$ TARUFFO, Michele. Consideraciones sobre prueba y verdad, p. 116.

${ }^{12}$ Sobre o direito à prova no processo penal, p. 40.

${ }^{13}$ GOMES FILHO, Antonio Magalhães. Sobre o direito à prova no processo penal, p. 47.
} 
Assim uma terceira vertente - que é adotada nesse trabalho - busca na verdade processual $^{14}$, traduzida para os autos do processo pelo exercício do direito à prova, o fundamento de justiça das decisões penais.

Conforme sustenta Michele Taruffo ${ }^{15}$ a busca da verdade há que ser inserida dentre os objetivos institucionais do processo ou, de outro modo, não haverá como se explicar racionalmente a justiça das decisões judiciais.

Em outras palavras, para a aplicação do direito material ao caso concreto considera-se imprescindível buscar, com fulcro nos limites legais e constitucionalmente estabelecidos, a verdade dos fatos trazidos à análise judicial, com vistas a obter uma decisão equânime e racionalmente justificável ${ }^{16}$.

Não é que as partes não tenham interesse na demonstração de sua versão dos fatos. É que ao juiz também cumpre atuar, supletivamente, com vistas a melhor esclarecer o ocorrido e só então decidir a causa ${ }^{17}$. O julgador, resguardados os limites de sua imparcialidade e da própria estrutura acusatória vigente no processo penal brasileiro ${ }^{18}$, deve atuar de forma excepcional, residual e dentro dos parâmetros das atividades probatórias desenvolvidas pelas partes, buscando elucidar o caso e fazer Justiça ${ }^{19}$.

\footnotetext{
${ }^{14} \mathrm{O}$ conceito de verdade processual será melhor abordado no item 1.2, adiante.

${ }^{15}$ La pueba de los hechos, p. 168.

${ }^{16}$ Conforme UBERTIS, Giulio. La prova penale: Profili giuridici ed epistemologici. Torino: UTE, 1999, p. 7. Nas palavras do autor: "L'accertamento della verità non è quindi, in sé e per sé, il fine ultimo del processo, ma il presupposto per poter adeguatamente decidire quale sia la legge applicabile nel caso concreto".

${ }^{17}$ UBERTIS, Giulio. La prova penale: Profili giuridici ed epistemologici, p. 13-14. Segundo o autor: "L'esito del processo scaturisce non da uma passiva recezione delle risultanze istruttorie da parte del giudice, ma da un'attiva partecipazione di tutti i soggetti processuali che intervengono com la loro personalità e da diverse prospettive in ogni momento dello sviluppo procedimentale influenzandone inevitabilmente il corso". E complementa ainda: "Il processo è actus trium personarum: l'ufficio dell'accusa, quello della difesa e quello del giudice concorrono tutti a realizzare la giurisdizione".

${ }^{18}$ GOMES FILHO, Antonio Magalhães. Provas Lei 11.690, de 09.06.2008. In: MOURA, Maria Thereza Rocha de Assis (Coord.). As Reformas no Processo Penal: As novas Leis de 2008 e os Projetos de Reforma. São Paulo: Revista dos Tribunais, 2008, p. 259.

${ }^{19}$ Conforme OLIVEIRA, Eugênio Pacelli de. Curso de Processo Penal. 10. ed. Rio de Janeiro: Editora Lumen Juris, 2008, p. 8-10. Na página 9 prevê o autor: "A iniciativa probatória do juiz deve limitar-se, então, ao esclarecimento de questões ou pontos duvidosos sobre o material já trazido pelas partes nos termos da redação do art. 156, II, do CPP”. Há, porém, entendimento em sentido contrário na doutrina nacional, sustentando que o referido dispositivo fere a presunção de inocência constitucional e o próprio sistema acusatório, preconizando a impossibilidade de verificar-se a iniciativa probatória judicial no sistema processual penal brasileiro, pois a dúvida deve beneficiar a defesa. Nesse sentido vide, dentre outros: BARROS, Flaviane de Magalhães. (Re)forma do Processo Penal: Comentários críticos dos artigos modificados pelas Leis n. 11.690/08, n. 11.719/08 e n. 11.900/09. 2. ed. Belo Horizonte: Del Rey, 2009, p. 33-35.
} 
De fato, em se tratando de processo penal não basta a mera plausibilidade da alegação para a decisão da causa, eis que vige no sistema brasileiro o princípio constitucional da presunção de inocência, disposto no artigo $5^{\circ}$, inciso LVII, da Constituição Federal. Somente a prova cabal e robusta dos fatos alegados pela acusação é capaz de afastar a presunção constitucional.

Assim, é pelo exercício do direito à prova que as partes poderão demonstrar a correspondência de sua versão dos fatos com o que deveras ocorreu, ou seja, é por meio da instrução probatória que as partes poderão comprovar a veracidade de suas alegações. E apenas com base no quanto provado o Magistrado poderá fundamentar seu julgamento.

Marco Antonio de Barros, defendendo também uma visão correspondencialista acerca da verdade no processo penal, segundo a qual verdade é a adequação ou conformidade entre o intelecto e a realidade ${ }^{20}$, apresenta um posicionamento intermediário entre as duas últimas correntes abordadas. Afirma existir um "vínculo umbilical que liga a reconstituição histórica dos fatos ao dever estatal de responder com a prestação jurisdicional justa e adequada às provas dos autos". Sustenta ainda o autor ser "mister descobrir a verdade para que a lei possa ser aplicada corretamente. E descobrir a verdade é oferecer conhecimentos capazes de convencer alguém (no caso o julgador) da existência ou inexistência de determinado fato, ou seja, uma relação de identidade, de adequação ou de acordo entre nosso pensamento e as coisas que constituem seu objeto". ${ }^{21}$

Portanto, segundo o autor, a busca da verdade deve ser fomentada no processo penal a fim de que seja oferecida ao indivíduo uma prestação jurisdicional justa. Por outro lado, a verdade estará caracterizada no caso pelo simples convencimento do julgador. Entretanto não se pode desconsiderar que o julgador, eventualmente, possa vir a se convencer e tomar como certo aquilo que seja falso ${ }^{22}$.

Nesse ponto, é preciso salientar que verdade e certeza não se confundem.

\footnotetext{
${ }^{20}$ BARROS, Marco Antonio de. A busca da verdade no Processo Penal. São Paulo: Editora Revista dos Tribunais, 2002, p. 17. Segundo o autor: "A verdade é fruto da inteligência humana. (...) Logo, a verdade é atributo de um juízo, não de uma prova. E o juízo que serve de base à verdade revela o próprio horizonte da verdade jurídica, que é demarcado pela justiça como fundamento". Tal pensamento é complementado nas páginas 14 e 15: "O intelecto é a inteligência, o entendimento, a razão, o conhecimento intelectual. A realidade é o ser. $\mathrm{Na}$ correspondência entre o intelecto e o ser firma-se a adequação de idéias constitutivas do objeto. Assim sendo, a verdade exige só a adequação ao objeto formal considerado em cada caso".

${ }^{21}$ BARROS, Marco Antonio de. A busca da verdade no Processo Penal, p. 21.

${ }^{22}$ TARUFFO, Michele. La semplice verità: Il giudice e la construzione dei fatti, p. 85-86.
} 
Conforme preconiza Nicola Framarino dei Malatesta $^{23}$ verdade é a conformidade da noção ideológica com a realidade e certeza é a crença que se tem nesta conformidade.

Segundo Michele Taruffo ${ }^{24}$ a verdade é objetiva e determinada pela realidade dos fatos de que se trata. A certeza, por sua vez, corresponde a um status subjetivo, atinente a impressão psicológica do indivíduo, e corresponde a um grau elevado de intensidade de convencimento do sujeito em questão.

Para que o julgador decida um processo-crime ele precisa, com fundamento nas provas produzidas em juízo, formar sua convicção jurídica de que as alegações trazidas aos autos por alguma das partes corresponde ao que efetivamente ocorreu no mundo fático. $\mathrm{Ou}$ seja, baseado nas provas produzidas no caso, ele precisa efetivamente acreditar que o quanto alegado ocorreu no caso sub judice. Em outras palavras, ele precisa ter certeza ${ }^{25}$.

Ressalte-se, porém, que o magistrado não poderá fundamentar sua decisão na certeza adquirida, visto que essa é subjetiva, mas tão somente nas provas constantes dos autos, que retratam a verdade do caso, demonstrando em juízo os fatos narrados ${ }^{26}$.

Denota-se assim a íntima relação existente entre os conceitos de verdade, certeza e prova, ligados umbilicalmente, bem como a relevância de seu estudo no direito processual penal.

\subsection{A superação da dicotomia entre verdade material $X$ verdade formal $e$ a construção do conceito de verdade processual}

Inegavelmente, a busca da verdade no Processo Penal sempre foi um norte a guiar seu curso.

\footnotetext{
${ }^{23}$ MALATESTA, Nicola Framarino dei. A lógica das provas em matéria criminal. Tradução de J. Alves de Sá. Campinas: Servanda Editora, 2009, p. 31.

${ }^{24}$ La semplice verità: Il giudice e la construzione dei fatti, p. 85.

${ }^{25}$ Ressalve-se nesse ponto que, conforme será abordado no item 1.3.1 adiante, em face da garantia constitucional do in dubio pro reo vigente no sistema processual penal brasileiro, o Magistrado precisará ter certeza apenas para a condenação, sendo que, em caso de dúvida, deverá decidir pela absolvição do acusado.

${ }^{26}$ TARUFFO, Michele. La semplice verità: Il giudice e la construzione dei fatti, p. 86-87.
} 
Entretanto, a História mostrou que tal busca embora tivesse como ideal possibilitar a efetivação de Justiça, caso fosse feita sem critérios rígidos e parâmetros prédeterminados, acabava por se tornar, de forma contraditória, fonte incessante de arbitrariedades e injustiças.

Representação disso, aliás, está na distinção feita pela doutrina durante muito tempo entre "verdade material" e "verdade formal".

A verdade material também chamada de verdade real ou substancial, objeto de desejo do Processo Penal exigia uma verdade dita absoluta, por lidar, em última análise, com um dos bens jurídicos mais caros ao indivíduo: a sua liberdade. Em razão disso, em tal sistema “o juiz teria mais poderes de iniciativa probatória, destinados à investigação da verdade e a realização do interesse público exigido pela justiça penal". ${ }^{27}$

Já a verdade formal seria suficiente ao Processo Civil, no qual, em regra, as disputas giram em torno de bens disponíveis (patrimoniais), contentando-se apenas com o quanto alegado e provado pelas partes litigantes.

Tal distinção fazia com que se afirmasse que para bem decidir uma causa penal fosse necessário conhecer a verdade real dos fatos ocorridos ${ }^{28}$. E, para que se obtivesse tal "verdade", acabava-se por legitimar o uso de meios de obtenção de prova espúrios e degradantes, como: a tortura, o soro da verdade, a invasão de domicílio, o desrespeito à intimidade do indivíduo com gravações clandestinas de imagens e diálogos etc.

Assim, a chamada busca da verdade material terminou por consolidar a prática de arbitrariedades ao invés de trazer Justiça para as decisões. Tratava-se de uma visão segundo a qual a busca da verdade era o fim do processo e não um meio.

Nesse sentido afirma José Osterno Campos de Araújo que "a busca da verdade não pode ser considerada como um valor absoluto, não se admitindo, por isso mesmo, que a verdade possa ser procurada com uso de quaisquer meios, mas tão somente através de meios justos, ou seja, legalmente admissíveis". ${ }^{29}$

\footnotetext{
${ }^{27}$ ÁVILA, Thiago André Pierobom. Provas ilícitas e Proporcionalidade. Rio de Janeiro: Editora Lumen Juris, 2007, p. 73-74.

${ }^{28}$ Conforme CHIMENTI, Francesco. O processo penal e a verdade material: teoria da prova. Rio de Janeiro: Forense, 1995, p. 84. O autor chega a afirmar in verbis: "O fim evidente do processo penal é a verdade real; e nesse diapasão parece-nos que se deveriam posicionar os processualistas penais de nossas sociedades".

${ }^{29}$ ARAÚJO, José Osterno Campos de. Verdade Processual Penal: Limitações à Prova. Curitiba: ABDR, 2005, p. 145.
} 
Atualmente tal diferenciação entre verdade real e verdade formal parece não ter mais razão de $\operatorname{ser}^{30}$. Seja porque tem sido cada vez mais freqüentes disposições acerca dos poderes instrutórios do juiz no âmbito do Processo Civil, mostrando que em muitos casos não basta apenas a produção probatória das partes $^{31}$, seja porque existem também no Processo Penal mecanismos de transação e conciliação que deixam a solução do conflito a critério das partes envolvidas $^{32}$, não havendo propriamente uma decisão judicial do caso, mas uma mera homologação do quanto acordado entre as partes.

Sob outro enfoque, perde-se também o interesse na distinção comumente feita pela doutrina entre verdade material e verdade formal, pelo fato de que hoje se sabe ser a verdade una e inatingível.

De fato, o conceito de verdade não comporta adjetivações como formal ou material, posto que a verdade é única. Ademais, a verdade em seu conceito absoluto é inatingível.

Nas palavras de Marco Antonio de Barros: "a verdade é um elemento fundamental que o Direito persegue e visa atingir. Todavia, nem sempre o intento é alcançado com sucesso". 33

A verdade é uma só e nunca poderá ser transmitida de forma exata para os autos do processo $^{34}$. Não é possível retratar de maneira absolutamente fidedigna para os autos fatos

${ }^{30}$ PITOMBO, Cleunice Aparecida Valentim Bastos. Processo Penal: Prova e Verdade, p. 111.

${ }^{31}$ É o que ocorre, por exemplo, no artigo 130 do Código de Processo Civil in verbis: "Art. 130 do CPC: Caberá ao juiz, de ofício ou a requerimento da parte, determinar as provas necessárias à instrução do processo, indeferindo as diligências inúteis ou meramente protelatórias".

${ }^{32}$ Como ocorre, por exemplo, com os artigos 72 e 76 da Lei $n^{\circ}$ 9.099/95, in verbis: "Art. 72 da Lei $n^{\circ}$ 9099/95: $\mathrm{Na}$ audiência preliminar, presente o representante do Ministério Público, o autor do fato e a vítima e, se possível, o responsável civil, acompanhados por seus advogados, o Juiz esclarecerá sobre a possibilidade da composição dos danos e da aceitação da proposta de aplicação imediata de pena não privativa de liberdade"; "Art. 76 da Lei n 9099/95: Havendo representação ou tratando-se de crime de ação penal pública incondicionada, não sendo caso de arquivamento, o Ministério Público poderá propor a aplicação imediata de pena restritiva de direitos ou multas, a ser especificada na proposta".

${ }_{33}^{3}$ BARROS, Marco Antonio de. A busca da verdade no Processo Penal, p. 23.

${ }^{34}$ BARROS, Marco Antonio de. A busca da verdade no Processo Penal, p. 18-20. Conforme explana o autor: "A unicidade da verdade existe e existirá sempre, independentemente do valor que se lhe atribua para efeito de obtenção do resultado do processo. (...) Certo é que a verdade não admite graduação. Um juízo é verdadeiro ou falso. (...) Não há duas vertentes distintas circundando o mesmo fato. $\mathrm{O}$ que pode haver é mais de um conhecimento subjetivo parcial da verdade, pois cada um conhece à sua maneira". E complementa o autor: "mas a verdade só é considerada válida no processo quando construída sobre uma base sólida de legalidade. Isto significa que a verdade deve ser moldada sob critérios de um juízo racional, previamente balizado pelo ordenamento jurídico. Sem dúvida, o conhecimento é subjetivo, porém sua composição submete-se ao preenchimento de requisitos próprios do devido processo legal. Desse modo, é o elemento objetivo que convalida a substância do conhecimento". 
reais ocorridos no passado, apresentados em juízo, em regra, por sujeitos parciais e mediante o uso de linguagem escrita, de forma precípua.

Por certo, a verdade de um enunciado é absoluta, não admitindo graus distintos. A alegação sobre o fato será verdadeira ou não. Entretanto, o grau de confirmação a que o referido enunciado estará submetido poderá variar.

De acordo com o contexto em que está inserido o fato e as alegações que são feitas acerca dele, dependendo ainda da metodologia empregada para a apuração da verdade dos fatos narrados, além da quantidade e qualidade de informação acerca do fato probando é possível se aproximar ou se distanciar da verdade.

Portanto o conhecimento acerca da verdade é variável, mas esta é una e determinada pela realidade do evento, representado pelas alegações acerca dos fatos feitas nos autos do processo ${ }^{35}$.

Assim, modernamente abandona-se a antiga classificação dicotômica entre verdade material (ou real) e verdade formal, por encontrar-se ultrapassada, passando a vigorar no campo processual penal o conceito de "verdade processualmente atingível ${ }^{36 " . ~ O u ~ s e j a, ~}$ busca-se no curso do processo a reprodução dos fatos ocorridos da forma mais fiel em relação ao que efetivamente ocorreu, respeitadas as limitações naturais e metodológicas impostas a essa busca ${ }^{37}$.

Em outras palavras busca-se retratar nos autos a exata correspondência dos fatos verificados no caso concreto, sabendo-se de antemão que tal intenção dificilmente se efetivará com perfeição por imposições e impossibilidades lógicas e epistemológicas.

De todo modo, como afirma Gustavo Henrique Righi Ivahy Badaró "mesmo aceitando-se a impossibilidade de se atingir um conhecimento absoluto, ou uma verdade incontestável dos fatos, não é possível abrir mão da busca da verdade, que é o único critério aceitável como premissa para uma decisão justa. $\mathrm{O}$ juiz deve procurar atingir o conhecimento

\footnotetext{
${ }^{35}$ TARUFFO, Michele. La semplice verità: Il giudice e la construzione dei fatti, p.82-83.

${ }^{36}$ A doutrina difere quanto à denominação conferida a esse fenômeno. Fala-se em "verdade atingível", "verdade aproximativa", "verdade jurídica objetiva", predominando porém a nomenclatura "verdade processual".

${ }^{37}$ Nesse sentido FERRAJOLI, Luigi. Direito e Razão: Teoria do Garantismo Penal. 2. ed. rev. e ampl. Tradução de Ana Paula Zomer Sica (et al). São Paulo: Editora Revista dos Tribunais, 2006, p. 52-53. O autor define a verdade processual como uma verdade aproximativa. Nos dizeres do autor: "A idéia contrária de que se pode conseguir e asseverar uma verdade objetiva ou absolutamente certa é, na realidade, uma ingenuidade epistemológica”.
} 
verdadeiro dos fatos para, diante da certeza de sua ocorrência - ou inocorrência -, fazer justiça no caso concreto", 38

De fato, como aponta Luigi Ferrajoli "se uma justiça penal integralmente 'com verdade' constitui uma utopia, uma justiça penal integralmente 'sem verdade' equivale a um sistema de arbitrariedade". 39

Conseqüentemente, em que pese as dificuldades teóricas e vedações práticas existentes à busca da verdade, não se pode olvidar que a verdade processualmente atingível há que ser necessariamente almejada no curso do processo ${ }^{40}$, visto que a Justiça do caso dependerá do conhecimento da verdade acerca dos fatos objeto de discussão em juízo ${ }^{41}$.

\section{3. $\mathrm{O}$ direito à prova}

O direito à prova no ordenamento jurídico brasileiro emerge da garantia constitucional ao contraditório $^{42}$ (artigo $5^{\circ}$, inciso $\mathrm{LV}$, da $\mathrm{CF}$ ), adquirindo também status constitucional.

Trata-se do direito público e subjetivo conferido às partes no processo de atuar em seu curso e influir sobre o seu resultado ${ }^{43}$. É um direito público, na medida em que tem como destinatário principal o Estado, representado na pessoa do Estado-juiz e subjetivo, no sentido de que confere verdadeiro poder aos indivíduos de fazerem valer seus direitos individuais.

\footnotetext{
${ }^{38}$ BADARÓ, Gustavo Henrique Righi Ivahy, Provas típicas e provas anômalas: inadmissibilidade da substituição da prova testemunhal pela juntada de declarações escritas de quem poderia ser testemunha. In: YARSHELL, Flávio Luiz; MORAES, Maurício Zanoide de (Orgs.). Estudos em Homenagem à Professora Ada Pellegrini Grinover. São Paulo: Editora DPJ, 2005, p. 343.

${ }^{39}$ FERRAJOLI, Luigi. Direito e Razão: Teoria do Garantismo Penal, p. 48.

${ }^{40}$ TARUFFO, Michele. La semplice verità: Il giudice e la construzione dei fatti, p.79.

${ }^{41}$ TARUFFO, Michele. La semplice verità: Il giudice e la construzione dei fatti, p. 119.

${ }^{42}$ Nesse sentido vide DALIA, Andrea Antonio; FERRAIOLI, Marzia. Manuale di Diritto Processuale Penale. $4^{\mathrm{a}}$ ed. Padova: CEDAM, 2001, p. 203.

${ }^{43}$ GRINOVER, Ada Pellegrini; FERNANDES, Antonio Scarance; GOMES FILHO, Antonio Magalhães. As Nulidades no Processo Penal. 10. ed. São Paulo: Revista dos Tribunais, 2007, p. 145.
} 
É consubstanciado como conseqüência lógica do direito ao acesso ao Judiciário (artigo $5^{\circ}$, inciso XXXIV, alínea $a$, da CF), expresso nos direitos de ação e de defesa ${ }^{44}$.

O direito de ação consiste na possibilidade de se exigir do Estado a chamada prestação jurisdicional. Isto é, que o Estado, através de seus órgãos competentes, tome conhecimento de determinado problema jurídico concreto, promovendo a aplicação do Direito ao caso. Ao direito de ação contrapõe-se, por imposição constitucional da garantia ao contraditório, o direito de defesa, resguardado nos mesmos moldes do primeiro.

O direito de petição, por sua vez, refere-se ao direito de apresentar ao Judiciário suas pretensões, obrigando o Poder Público, em conseqüência, a ofertar uma resposta.

De fato, o direito de ser ouvido em juízo compreende o direito de aduzir suas pretensões e de demonstrar em juízo a veracidade de suas alegações, com a garantia de poder atuar de forma pró-ativa sobre o convencimento do julgador ${ }^{45}$.

Assim, pode-se afirmar que o direito à prova desdobra-se nos direitos à proposição da prova pelas partes, à sua admissão pelo Magistrado, à produção probatória quando da instrução processual e à valoração dos elementos de prova, no momento da decisão judicial $^{46}$.

Para um adequado estudo do tema serão abordados a seguir o objeto de prova, a questão do ônus da prova no processo penal brasileiro e demais definições em matéria probatória, tais como: elemento de prova, resultado de prova, fonte de prova, meio de prova e meio de investigação de prova, além de ser feita a necessária distinção entre provas ilegais, ilícitas e ilegítimas.

Como qualquer direito, cumpre salientar que também o direito à prova encontra limites ao seu exercício impostos pelo próprio ordenamento jurídico. Dentre tais limitações insere-se a prova ilícita e particularmente a prova ilícita por derivação, também chamada teoria dos frutos da árvore envenenada ${ }^{47}$, tema deste trabalho.

\footnotetext{
${ }^{44}$ ÁVILA, Thiago André Pierobom. Provas ilícitas e Proporcionalidade, p. 87.

${ }^{45}$ GOMES FILHO, Antonio Magalhães. Sobre o direito à prova no processo penal, p. 81.

${ }^{46}$ Para o conteúdo do direito à prova vide: GOMES FILHO, Antonio Magalhães. Sobre o direito à prova no processo penal, p. 82 ss.

${ }^{47}$ A doutrina é conhecida nos Estados Unidos da América como fruits of the poisonous tree doctrine. No Brasil é comumente traduzida por "teoria dos frutos da árvore envenenada", nomenclatura também adotada nesse trabalho por encontrar-se consagrada na doutrina e Jurisprudência pátrias. Entretanto há que se notar que em uma tradução literal poisonous significa venenosa e poisoned seria envenenada. Assim, ainda que pouco usual, tecnicamente, melhor seria a tradução de tal expressão para "teoria dos frutos da árvore venenosa". Note-se que em
} 


\subsubsection{Objeto de prova e ônus da prova no processo penal brasileiro}

Conforme a sistemática processual penal vigente no ordenamento jurídico brasileiro, em face dos elementos de prova insertos nos autos, caso haja dúvida no espírito do julgador da causa e não sendo esta sanada por mecanismos complementares de instrução probatória judicial (conforme previsto no inciso II do artigo 156 do Código de Processo Penal) ${ }^{48}$ deverá o juiz decidir favoravelmente ao réu (in dubio pro reo), como consequiência lógica da adoção do princípio constitucional da presunção de inocência no ordenamento pátrio ${ }^{49}$.

Como mencionado anteriormente, no processo penal não basta a verossimilhança da alegação, pois esta não é capaz de superar a presunção constitucional de inocência do réu. "Para proferir uma decisão condenatória, deve o juiz ter a certeza de que, dos elementos constantes do processo, surgiu a verdade acerca dos fatos apurados". 50

Assim, as alegações feitas em juízo devem ser objeto de prova a fim de poderem influenciar na livre convicção do Magistrado da causa.

Salvo poucas exceções, como os casos de fatos notórios, fatos impertinentes ou irrelevantes para o deslinde do feito, dentre alguns outros, a regra que vigora no sistema processual brasileiro é a de que, as alegações acerca dos fatos, que se diz terem ocorrido no caso concreto, e constam dos autos do processo, devem ser objeto de prova.

GRINOVER, Ada Pellegrini. Liberdades Públicas e Processo Penal: as interceptações telefônicas, 2. ed. São Paulo: Editora Revista dos Tribunais, 1982, p 126, a autora fala da proibição de se utilizar qualquer fruto de uma planta venenosa, tratando acerca da ilicitude por derivação.

48 “Art. 156 do CPP: A prova da alegação incumbirá a quem a fizer, sendo, porém, facultado ao juiz de ofício: (...)

II - determinar, no curso da instrução, ou antes de proferir sentença, a realização de diligências para dirimir dúvida sobre ponto relevante".

${ }^{49}$ JÚNIOR, Aury Lopes. Direito Processual Penal e sua Conformidade Constitucional. 3. ed. Rio de Janeiro: Editora Lumen Juris, 2010. v. II, p. 194.

${ }^{50}$ SIMONS, Christian Sthefan. A prova ilícita no direito processual penal norte-americano e alemão e as influências no processo penal brasileiro. 2007. 168 f. Dissertação (Mestrado em Direito) - Faculdade de Direito, Universidade de São Paulo, São Paulo, p. 18. 
De fato são objeto de prova em juízo as alegações feitas acerca de um fato e não o fato propriamente dito ${ }^{51}$.

Conforme explana Gustavo Henrique Righi Ivahy Badaró os fatos são acontecimentos que têm existência no mundo real. $\mathrm{O}$ fato não comporta adjetivações ou valorações, simplesmente ocorreu ou não. "Verdadeiros ou falsos só podem ser nossos conhecimentos, nossas percepções, nossas opiniões, nossos conceitos ou nossos juízos a respeito de um objeto. Os 'fatos' debatidos no processo são enunciados sobre os fatos do mundo real, isto é, aquilo que se diz em torno de um fato: é a enunciação de um fato e não o próprio fato. Em consequiência, o objeto de prova não é o próprio fato. $\mathrm{O}$ que se prova são as alegações dos fatos feitas pelas partes como fundamentos da acusação e da defesa". ${ }^{52}$

Logo, não basta a mera narrativa das versões dos fatos ocorridos e constante dos autos do processo, é preciso provar o quanto alegado.

É o que apregoa a regra de distribuição de ônus probatório, com suas especificações e mitigações em se tratando do processo penal brasileiro.

José Carlos Barbosa Moreira define ônus processual como sendo "o ato que alguém precisa praticar para tornar possível a obtenção de uma vantagem ou para afastar a consumação de uma desvantagem". ${ }^{53}$

Gustavo Henrique Righi Ivahy Badaró conceitua ônus "como uma posição jurídica na qual o ordenamento jurídico estabelece determinada conduta para que o sujeito

51 Conforme consta da obra de CINTRA, Antonio Carlos de Araújo; GRINOVER, Ada Pellegrini; DINAMARCO, Cândido Rangel. Teoria Geral do Processo. 20. ed. São Paulo: Editora Malheiros, 2004, p. 349 são objeto de prova as alegações feitas acerca dos fatos que se diz terem ocorrido no mundo fenomênico e introduzidas nos autos do processo por meio de narrativas escritas. De fato, predomina o entendimento de que no curso do processo ficam provadas as alegações feitas acerca dos fatos e não estes propriamente. Ademais, note-se que, em regra, todas as afirmações devem ser objeto de atividade probatória, para poderem influenciar na convicção do Magistrado da causa. Entretanto, usualmente algumas exceções a tal regra são trazidas pela doutrina. Assim, conforme dispõe NUCCI, Guilherme de Souza. Provas no Processo Penal. São Paulo: Editora Revista dos Tribunais, 2009, p. 16-17, não precisa ser provado o direito, salvo quanto à existência e o conteúdo de normas internacionais, estaduais ou municipais, desde que de unidades federativas diversas da do juiz do feito. Além disso, não são objeto de prova os fatos notórios, fatos atuais, de conhecimento geral em todo território nacional, bem como as ditas verdades sabidas, que englobam os fatos cientificamente demonstrados e universalmente aceitos e os fatos intuitivos, decorrentes da experiência consolidada do ser humano. Tampouco necessitam serem provados em juízo os fatos irrelevantes ou impertinentes, por não serem necessários à solução da causa. Em sentido contrário, sustentando que são objeto de prova os fatos propriamente e não as alegações feitas acerca dos fatos vide DALIA, Andrea Antonio; FERRAIOLI, Marzia. Manuale di Diritto Processuale Penale, p. 204.

52 BADARÓ, Gustavo Henrique Righi Ivahy. Ônus da Prova no Processo Penal. São Paulo: Editora Revista dos Tribunais, 2003, p. 159-160.

${ }^{53}$ MOREIRA, José Carlos Barbosa. Comentários ao Código de Processo Civil. 8. ed. Rio de Janeiro: Editora Forense, 1999. v. V, p. 235. 
possa obter um resultado favorável". ${ }^{54}$ Isto é, para que o sujeito onerado possa obter um resultado favorável, deverá praticar o ato previsto no ordenamento jurídico, de modo que a não realização da referida conduta implicará a exclusão do benefício, mas não configurará um ato ilícito.

Vale ressaltar que ônus processual se distingue de deveres e obrigações. ${ }^{55}$ Deveres são imperativos perante uma coletividade, já obrigações são imperativos do interesse do credor em face do devedor. Ônus, por sua vez, são imperativos do próprio interesse.

O ônus da prova constitui-se em uma determinação trazida pelo ordenamento jurídico para que a parte no processo produza provas em juízo com vistas a demonstrar a sua versão sobre os fatos probandos e influir na convicção judicial, visando obter uma sentença favorável.

O princípio da presunção de inocência, consubstanciado no direito fundamental inserto no artigo $5^{\circ}$, inciso LVII, da Constituição Federal, dispõe que "ninguém será considerado culpado até o trânsito em julgado de sentença penal condenatória” e traz como conseqüência prática, dentre outras implicações, a fixação de uma regra diferenciada para a questão probatória no processo criminal.

Assim, afirma-se que no Processo Penal o ônus probatório fica a encargo do órgão acusador, não possuindo a defesa qualquer ônus de fazer prova, pois é beneficiária da presunção de inocência constitucional.

Nesse sentido Maurício Zanoide de Moraes sustenta que o tema conta com significativo consenso doutrinário nos países em que o referido princípio está inserido em nível constitucional. "Para todos eles, o ônus de provar no processo penal é da acusação, uma vez que, partindo o órgão acusador do pressuposto juspolítico do 'estado de inocência' do

\footnotetext{
${ }^{54}$ BADARÓ, Gustavo Henrique Righi Ivahy. Ônus da Prova no Processo Penal, p. 173.

${ }^{55}$ Para mais explanações vide: BADARÓ, Gustavo Henrique Righi Ivahy. Ônus da Prova no Processo Penal, p. 176-177. Segundo diferenciação feita pelo autor: "Ao direito subjetivo corresponde uma obrigação. O poder tem como correlato a sujeição. Já perante o ônus não há qualquer posição contraposta. Não há um outro sujeito que não o próprio onerado. (...) A parte contrária não quer outra coisa senão que o onerado não se desincumba de seu ônus. O cumprimento do ônus interessa ao próprio sujeito onerado, enquanto, na obrigação, a sua satisfação interessa à outra parte (...). O inadimplemento de uma obrigação ou de um dever gera uma situação de ilicitude e traz como consequiência a possibilidade de uma sanção. Já o descumprimento de um ônus configura um ato lícito".
} 
cidadão, é a ele que caberá demonstrar sua tese pela culpa do indivíduo e, portanto, caberá a ele o ônus de demonstrar essa tese não proposta pela Constituição". ${ }^{56}$

Gustavo Henrique Righi Ivahy Badaró $^{57}$ no mesmo sentido preconiza que, em face do in dubio pro reo vigente no ordenamento brasileiro, o acusado jamais poderá ser prejudicado pela dúvida acerca de um fato relevante para a solução de um caso criminal. É que a presunção de inocência atribui o encargo probatório exclusivamente ao acusador.

Também para Antonio Magalhães Gomes Filho "em um processo penal orientado pela presunção de inocência, é evidentemente inadequado falar em ônus da prova, especialmente em relação à defesa, pois se o acusado é considerado inocente até que se comprove legalmente sua culpabilidade, é claro que o encargo de demonstrar os fatos incumbe integralmente à acusação: e, como consequiência, não atendido o referido ônus, a dúvida deve ser solucionada pro reo. E o mesmo deve ser dito a respeito de uma eventual incerteza sobre a ocorrência de uma causa de justificação ou exclusão de responsabilidade". ${ }^{58}$

Entretanto, é preciso notar que existe também na doutrina nacional posição minoritária contrária às acima trazidas, sustentando que, como ocorre no Processo Civil, a partir do quanto disposto no artigo 333 do $\mathrm{CPC}^{59}$, com disposição semelhante também no Código de Processo Penal atual ${ }^{60}$, a prova da alegação no âmbito do processo-crime caberá a quem a fizer.

Assim, Guilherme de Souza Nucci ${ }^{61}$ aduz caber inicialmente à acusação o ônus de provar ser o acusado culpado do crime que lhe é imputado, de modo que o réu que

\footnotetext{
${ }^{56}$ MORAES, Maurício Zanoide de. Presunção de Inocência no Processo Penal Brasileiro: análise de sua estrutura normativa para a elaboração legislativa e para a decisão judicial. 2008. 603. f. Tese (Livre- docência do Departamento de Direito Processual) - Faculdade de Direito, Universidade de São Paulo, São Paulo, p. 491.

${ }^{57}$ Ônus da Prova no Processo Penal, p. 239-240.

${ }^{58}$ GOMES FILHO, Antonio Magalhães. A presunção de inocência e o ônus da prova em processo penal. Boletim IBCCRIM, São Paulo, n. 23, nov. 1994, p. 03.

59 "Artigo 333 do CPC: O ônus da prova incumbe:

I - ao autor, quanto ao fato constitutivo do seu direito;

II - ao réu, quanto à existência de fato impeditivo, modificativo ou extintivo do direito do autor.

Parágrafo único. É nula a convenção que distribui de maneira diversa o ônus da prova quando:

I - recair sobre direito indisponível da parte;

II - tornar excessivamente difícil a uma parte o exercício do direito".

60 "Artigo 156 do CPP: A prova da alegação incumbirá a quem a fizer, sendo, porém, facultado ao juiz de ofício:

I - ordenar, mesmo antes de iniciada a ação penal, a produção antecipada de provas consideradas urgentes e relevantes, observando a necessidade, adequação e proporcionalidade da medida;

II - determinar, no curso da instrução, ou antes de proferir sentença, a realização de diligências para dirimir dúvida sobre ponto relevante".

${ }^{61}$ Provas no Processo Penal, p. 22-23.
} 
pretender apenas negar a imputação poderá permanecer inerte, pois seu estado de inocência prevalece. Por outro lado, segundo o mesmo autor, se a defesa alegar fato diferenciado daqueles constantes da peça acusatória trará para si o ônus da prova, como ocorre com a sustentação de um álibi ou quando o acusado invoca em seu favor alguma excludente de ilicitude ou de culpabilidade.

Para esta segunda vertente, portanto, o dever de provar caberá a quem alegar: à acusação ao imputar uma infração penal ao réu e ao acusado ao sustentar sua tese de defesa. A diferença principal entre acusação e defesa estará na conseqüência processual pelo não cumprimento de tal ônus probatório, ou seja, se o órgão responsável pela acusação não se desincumbir de forma satisfatória de seu ônus, gerando a dúvida no espírito do julgador este então deverá decidir favoravelmente à defesa, afinal in dubio pro reo.

Nascendo para o julgador dúvida com relação aos fatos alegados e não provados, de maneira que não lhe seja possível formar internamente a sua convicção e certeza jurídica necessária para julgar o caso, deverá decidir a favor do acusado e sempre em prol da liberdade.

De fato, em que pese a distinção doutrinária, certo é que, em vista do quanto determina a Constituição brasileira, não resta à defesa qualquer ônus probatório, pois ainda que o réu permaneça inerte na fase instrutória, terá sempre em seu favor o benefício da dúvida $^{62}$. Já o órgão de acusação, por sua vez, se não provar a contento suas alegações, terá como resultado prático a absolvição ${ }^{63}$.

Conforme explica Gustavo Henrique Righi Ivahy Badaró, “o ônus da prova funciona como um sucessor da verdade, isto é, um caminho a ser seguido pelo juiz que, ao

\footnotetext{
${ }^{62}$ É aliás o que propugna o artigo 386, inciso VI, parte final do CPP, com redação proposta a partir da Lei ${ }^{\circ}$ 11690/08. "Artigo 386 do CPP: O juiz absolverá o réu, mencionando a causa na parte dispositiva, desde que reconheça:

(...)

VI - existirem circunstâncias que excluam o crime ou isentem o réu de pena (arts. 20, 21, 22, 23, 26 e $\S 1^{0}$ do art. 28, todos do Código Penal), ou mesmo se houver fundada dúvida sobre sua existência" (grifo nosso).

${ }^{63}$ MORAES, Maurício Zanoide de. Presunção de Inocência no Processo Penal Brasileiro: análise de sua estrutura normativa para a elaboração legislativa e para a decisão judicial, p. 443-448. O autor critica a expressão "absolvição por não existir prova suficiente para a condenação" adotada pelo Código de Processo Penal no artigo 386, inciso VII, por entender que se a regra instituída pela Constituição Federal é a presunção de inocência não seria correto falar em insuficiência de provas para a condenação, pois esta seria exceção no âmbito do processo penal.
} 
término do processo, encontra-se em estado de incerteza, por não ter sido possível atingir o conhecimento verdadeiro sobre os fatos". ${ }^{64}$

Assim, em sede processual penal, em caso de dúvida deverá o juiz sempre decidir favoravelmente à defesa, por imposição constitucional.

\subsubsection{Definições doutrinárias em matéria de prova}

Em matéria probatória inexiste uniformidade terminológica dentre os juristas. Não havendo nem mesmo consenso acerca da própria definição de prova.

Conforme Eugenio Florian ${ }^{65}$ provar significa fornecer aos autos do processo o conhecimento de qualquer fato, de maneira que se adquira para si ou se engendre em outros a convicção da existência ou da verdade do fato objeto de prova.

Karl Joseph Anton Mittermaier ${ }^{66}$ define prova como sendo a soma dos motivos geradores de certeza acerca dos fatos.

Nicola Framarino dei Malatesta ${ }^{67}$ entende prova como a relação particular existente entre convicção e verdade.

Antonio Magalhães Gomes Filho ressalta a dificuldade de lidar com o tema em razão "do emprego nem sempre adequado, de certas expressões próprias da linguagem comum, da terminologia filosófica e científica ou mesmo elaboradas em outras culturas jurídicas, que nem sempre servem para esclarecer a natureza dos fenômenos ligados à prova judiciária, mas, ao contrário, muito contribuem para incertezas, equívocos e contradições" 68 Além disso, alerta para a natureza polissêmica do próprio termo prova, ora empregado pelo Código de Processo Penal brasileiro como "meio de prova", ora como "resultado de prova", ora ainda como "elemento de prova".

\footnotetext{
${ }^{64}$ BADARÓ, Gustavo Henrique Righi Ivahy. Ônus da Prova no Processo Penal, p. 20.

${ }^{65}$ FLORIAN, Eugenio. De las pruebas penales. Bogotá: Editorial Temis, 1968. tomo I, p. 3.

${ }^{66}$ MITTERMAIER, Karl Joseph Anton. Tratado de la prueba em materia criminal. Tradução de Primitivo González Del Alba. Buenos Aires: Hammurabi, 2006, p. 75.

${ }^{67}$ MALATESTA, Nicola Framarino dei. A lógica das provas em matéria criminal, p. 101-102.

${ }^{68}$ GOMES FILHO, Antonio Magalhães, Notas sobre a terminologia da prova (reflexos no processo penal brasileiro). In: YARSHELL, Flávio Luiz; MORAES, Maurício Zanoide de (Orgs.). Estudos em Homenagem à Professora Ada Pellegrini Grinover. São Paulo: Editora DPJ, 2005, p. 304.
} 
Assim, com vistas a possibilitar um estudo científico acerca do tema, mas sem o condão de pretender esgotar o assunto, serão apresentados alguns conceitos e definições predominantes na doutrina nacional acerca da temática da prova penal.

Preocupado com a falta de uniformidade e rigor técnico na utilização da linguagem processual penal é também de Antonio Magalhães Gomes Filho a proposta de distinção entre elementos de prova e resultado da prova, adotada neste trabalho.

Elementos de prova são "os dados objetivos que confirmam ou negam uma asserção a respeito de um fato que interessa à decisão da causa", por exemplo, "a declaração de uma testemunha sobre determinado fato, a opinião de um perito sobre a matéria de sua especialidade, o conteúdo de um documento etc.". 69

Resultados da prova são as conclusões extraídas pelos julgadores a partir dos diversos elementos de prova existentes no caso acerca de um fato probando ${ }^{70}$. Trata-se aqui de um processo mental e lógico desenvolvido pelos juízes ao analisarem os elementos de prova existentes no caso em análise para decidirem se as afirmações feitas em juízo são verdadeiras ou não e, então, bem decidir a causa. Esse raciocínio empregado há que ser obrigatoriamente demonstrado e especificado, a exceção dos jurados do Tribunal do Júri, que dispõem da prerrogativa da livre convicção, não precisando fundamentar suas decisões.

Antonio Magalhães Gomes Filho apresenta ainda as seguintes conceituações para fonte de prova, meio de prova e meio de investigação da prova ${ }^{71}$.

Fontes de prova são as pessoas ou coisas das quais se possa extrair o elemento de prova, por exemplo: testemunhas, vítimas, documentos etc.

Meios de prova, por sua vez, são os instrumentos ou atividades por intermédio das quais os elementos de prova são introduzidos e fixados no processo. São veículos de ingresso dos elementos de prova nos autos do processo ${ }^{72}$. Como por exemplo, um depoimento de uma testemunha, ou a admissão de um documento nos autos do processo.

\footnotetext{
${ }^{69}$ GOMES FILHO, Antonio Magalhães. Notas sobre a terminologia da prova (reflexos no processo penal brasileiro), p. 307.

${ }^{70}$ Nesse sentido também FELICIONI, Paola. Le ispezioni e le perquisizioni. Milano: Giuffrè, 2004, p. 26. A autora conceitua ainda fonte de prova como o sujeito ou objeto dos quais possa derivar ao menos um elemento de prova para o processo e meio de prova como a atividade consistente em introduzir no processo os elementos de prova.

${ }^{71}$ GOMES FILHO, Antonio Magalhães, Notas sobre a terminologia da prova (reflexos no processo penal brasileiro), p. 308-310.

${ }^{72}$ DALIA, Andrea Antonio e FERRAIOLI, Marzia. Manuale di Diritto Processuale Penale, p. 211.
} 
Meios de obtenção de prova, também chamados de meios de pesquisa ou meios de investigação de prova referem-se a certos procedimentos, em geral extraprocessuais, regulados por lei, com o objetivo de obter fontes de provas acerca de uma assertiva que seja objeto de prova, isto é, que se pretenda seja confirmada ou não em juízo. São exemplos de meios de obtenção de prova as buscas e apreensões.

Nos dizeres de Antonio Magalhães Gomes Filho e como será abordado no próximo tópico "na prática, essa diversidade terminológica também serve para identificar as possíveis repercussões das irregularidades verificadas em relação aos meios de prova e aos meios de investigação. No primeiro caso, a conseqüência do vício será a nulidade dos elementos de prova produzidos, enquanto no segundo tratar-se-á de prova inadmissível no processo, diante da violação de regras relacionadas à sua obtenção $\left(\operatorname{art.} 5^{\circ}, \mathrm{LVI} \text {, da CF }\right)^{73}$,"

Vale ressaltar que irregularidades cometidas na busca por fontes de prova, ou seja, nos meios de obtenção de prova, podem culminar na ilicitude da própria fonte de prova e dos elementos de prova dela extraídos, com a conseqüente inadmissibilidade no processo do respectivo meio de prova, conforme será visto em detalhes.

\subsubsection{Provas ilegais, ilícitas e ilegítimas}

Também em matéria de vedações probatórias não há uniformidade terminológica.

Manuel da Costa Andrade, tratando especificamente da questão assim se posiciona: "não se encontra zona da vida jurídica onde os caminhos da doutrina e jurisprudência se mostrem mais desencontrados e varridos pela controvérsia. Dificilmente, com efeito, o jurista conhecerá experiência mais próxima de Babel: falando todos do mesmo (proibições de prova), raros falam, afinal, da mesma coisa". ${ }^{74}$

\footnotetext{
${ }^{73}$ GOMES FILHO, Antonio Magalhães, Notas sobre a terminologia da prova (reflexos no processo penal brasileiro), p. 310.

${ }^{74}$ ANDRADE, Manuel da Costa. Sobre as Proibições de Prova em Processo Penal. Coimbra: Coimbra Editora, 2006, p. 19.
} 
Marcos Alexandre Coelho Zilli também se manifestou sobre o assunto. Segundo o autor: "qualquer incursão sobre a temática relativa à prova ilícita exige a superação de uma tarefa que lhe antecede, qual seja, a busca por uma precisão terminológica. No mais das vezes, expressões como prova ilegítima, proibida, vedada e ilegal são empregadas em um sentido equivalente, indicando a mesma fenomenologia. O rigor doutrinário, todavia, não admite tal confusão". ${ }^{75}$

De acordo com Fabricio Guariglia ${ }^{76}$ esta diversidade terminológica - que ora fala em proibições probatórias, ora em provas proibidas, exclusões de provas e provas ilícitas-, para além de uma questão semântica, denota uma real confusão verificada em torno do que seja proibido em matéria probatória no âmbito processual penal.

De fato, em que pese o desencontro terminológico referido pelos autores, alguns conceitos são definidos pela doutrina.

Pietro Nuvolone ${ }^{77}$ propôs conceituações para provas ilegais, ilícitas e ilegítimas, reproduzidas para o Brasil primeiramente por Ada Pellegrini Grinover ${ }^{78}$ e então acolhidas de forma majoritária pelos processualistas penais brasileiros.

De acordo com o referido autor as provas ilegais, também chamadas de provas vedadas ou proibidas, constituem o gênero das quais as provas ilícitas e ilegítimas são espécies.

A prova será considerada ilegal quando sua obtenção resultar em uma violação de normas legais ou de princípios gerais do ordenamento, de natureza processual ou material. Será considerada ilegítima quando contrariar uma lei processual e ilícita quando a proibição for de natureza material ${ }^{79}$.

Oswaldo Trigueiro do Valle Filho, por sua vez, apresenta classificação distinta. $\mathrm{O}$ autor fala em prova proibida ou prova vedada, referindo-se à dimensão mais ampla. Caso a

75 ZILLI, Marcos Alexandre Coelho. A prova ilícita e o Tribunal Penal Internacional: Regras de admissibilidade. 2006. 290 f. Tese (Doutorado em Direito) - Faculdade de Direito, Universidade de São Paulo, São Paulo, p. 173.

${ }^{76}$ GUARIGLIA, Fabricio. Las prohibiciones de valoración probatoria en el procedimiento penal. Jueces para la Democracia, Madrid, n. 26, jul. 1996, p. 77.

${ }^{77}$ NUVOLONE, Pietro. Le prove vietate nel processo penale nei paesi di diritto latino. Rivista di Diritto Processuale, Padova, v. XXI, 1966, p. 442-475.

${ }^{78}$ Conforme consta de GRINOVER, Ada Pellegrini. Liberdades Públicas e Processo Penal: as interceptações telefônicas, p. 93-103.

${ }^{79}$ GRINOVER, Ada Pellegrini; FERNANDES, Antonio Scarance; GOMES FILHO, Antonio Magalhães. As Nulidades no Processo Penal, p. 158-159. 
violação probatória seja a uma norma de ordem material teríamos a prova ilícita. Já "quando a violação fulmina a linha de estrutura processual, maculando a base de uma funcionalidade do processo, o termo que se apresenta mais funcional é a chamada prova ilegal". ${ }^{80}$

Guilherme de Souza Nucci ${ }^{81}$ sugere ainda uma terceira classificação, segundo a qual as provas ilícitas seriam divididas em ilegais, quando em sua obtenção houvesse violação de norma penal, e ilegítimas, no caso de infração a normas processuais penais.

No presente trabalho será adotada a classificação de Pietro Nuvolone, feitas algumas observações importantes.

Conforme o referido entendimento - e maiores explanações no item 1.5 - podese afirmar que nas provas ilícitas a ilegalidade advém de sua obtenção, enquanto nas provas ilegítimas a invalidade advém de sua produção. Os impeditivos legais surgem em momentos diversos em cada uma delas. Além disso, a conseqüência de tais vícios também se mostra variada: as ilícitas não são admitidas no processo e caso nele sejam inseridas deverão ser desentranhadas dos autos. Já as provas ilegítimas deverão ser refeitas sem o vício anterior e serão, então, plenamente válidas ${ }^{82}$.

Nas palavras de Ada Pellegrini Grinover "a prova será ilícita, infringindo, portanto, norma material, quando for 'colhida' de forma que transgrida regra posta pelo direito material; será ao contrário, ilegítima, infringindo norma de caráter processual, quando for 'produzida' no processo, em violação à regra processual'. ${ }^{83}$

Detalhando esta idéia, Ada, Scarance e Magalhães esclarecem que a prova deveria ser considerada ilícita e, logo, inadmissível no processo se "colhida infringindo-se normas ou princípios colocados pela Constituição e pelas leis, freqüentemente para a proteção das liberdades públicas e dos direitos da personalidade e daquela sua manifestação que é o direito à intimidade". ${ }^{84}$

É também nesse sentido a definição proposta por César Dario Mariano da Silva: “As provas ilícitas infringem normas ou princípios de direito material, sobretudo de direito

\footnotetext{
${ }^{80}$ VALLE FILHO, Oswaldo Trigueiro do. A ilicitude da prova: teoria do testemunho de ouvir dizer. São Paulo: Editora Revista dos Tribunais, 2004, p. 43-44.

${ }^{81}$ Provas no Processo Penal, p. 31.

${ }^{82}$ GOMES FILHO, Antonio Magalhães. Provas Lei 11.690, de 09.06.2008, p. 265-266.

${ }^{83}$ GRINOVER, Ada Pellegrini. Provas ilícitas. Separata da Revista da Procuradoria Geral do Estado, São Paulo, n. 16, jun. 1980, p. 98.

${ }^{84}$ GRINOVER, Ada Pellegrini; FERNANDES, Antonio Scarance; GOMES FILHO, Antonio Magalhães. As Nulidades no Processo Penal, p. 159.
} 
constitucional, ensejando infração de direito penal, civil ou administrativo. Consubstanciam-se em afronta às liberdades públicas protegidas pela Constituição Federal". ${ }^{85}$

Luiz Francisco Torquato Avolio define prova ilícita, como aquela colhida com infração a normas ou princípios de direito material, sobretudo de direito constitucional, pois segundo o autor "a problemática da prova ilícita se prende sempre à questão das liberdades públicas, onde estão assegurados os direitos e garantias atinentes à intimidade, à liberdade, à dignidade humana". 86

Segundo explicações de Marcos Alexandre Coelho Zilli ${ }^{87}$, tanto as provas ilícitas quanto as ilegítimas indicam a contrariedade ao direito. Entretanto, enquanto a prova ilícita relaciona-se diretamente com a violação de direitos fundamentais constitucionalmente assegurados, a ilegítima provém da inobservância de normas de caráter processual. Além disso, o momento de configuração da ilegalidade é distinto: a ilicitude vincula-se à obtenção de prova com o emprego de métodos lesivos aos valores ligados à preservação da dignidade humana (a integridade física, liberdade, intimidade do indivíduo, dentre outros). Já a ilegitimidade, por sua vez, é verificada na introdução ou na produção da prova no processo, mediante o descumprimento de formas estabelecidas em lei.

Percebe-se, portanto, uma inclinação da doutrina pátria moderna em identificar as provas ilícitas com àquelas obtidas em ofensa a direitos fundamentais e não meramente direitos materiais.

Christian Sthefan Simons, nesse sentido, propõe um conceito para as provas ilícitas como sendo "as provas obtidas mediante violação de normas processuais que tutelam direitos materiais de forma imediata e de índole constitucional". ${ }^{88}$

\footnotetext{
${ }^{85}$ SILVA, César Dario Mariano da. Provas Ilícitas. 4. ed. Rio de Janeiro: Editora Forense, 2005, p. 15-16.

${ }^{86}$ AVOLIO, Luiz Francisco Torquato. Provas ilícitas: Interceptações telefônicas, ambientais e gravações clandestinas. 3. ed. São Paulo: Editora Revista dos Tribunais, 2003, p. 43.

${ }^{87}$ A prova ilícita e o Tribunal Penal Internacional: Regras de admissibilidade, p. 174-175.

${ }^{88}$ SIMONS, Christian Sthefan. A prova ilícita no direito processual penal norte-americano e alemão e as influências no processo penal brasileiro, p. 111. Acerca do conceito proposto explica o autor: "As normas processuais tutelam o direito material, podendo esta tutela ser realizada de modo imediato ou mediato. Por tutela mediata, entenda-se a proteção que uma norma processual fornece à outra como forma de salvaguardar o direito material. Neste sentido, podem-se citar como exemplo as regras acerca das nulidades, que visam garantir a regularidade formal do processo como forma de garantir o direito material das partes (...). Por outro lado, as regras processuais podem tutelar o direito material de forma imediata, como por exemplo, a disciplina da busca e apreensão (...) (proteção à intimidade e à inviolabilidade do domicílio), a disciplina da lei 9296/96 acerca das interceptações telefônicas (proteção ao sigilo das comunicações)".
} 
Também para Thiago André Pierobom de Ávila “o direito cuja violação ensejará a ilicitude da prova há de ser um direito fundamental". ${ }^{89}$

Aliás, era também nesse sentido a redação originalmente sugerida para o artigo 157 do CPP pela Comissão constituída pelo então Ministro da Justiça, Senhor José Carlos Dias e presidida pela professora Ada Pellegrini Grinover, para propor reformas ao Código de Processo Penal.

De fato, atualmente, mesmo em face da confusa redação conferida ao artigo 157 do CPP que trata das provas ilícitas originais e derivadas, e que será oportunamente abordado, verifica-se forte tendência no sentido de definir provas ilícitas como aquelas que ofendam direitos fundamentais dos indivíduos, para além dos direitos materiais, já preconizados há tempos por Pietro Nuvolone. É este também o entendimento adotado por esse trabalho, como será explanado detalhadamente no item 3.3.1.

\subsubsection{Limites ao direito à prova}

Como ocorre com qualquer direito, também o direito à prova encontra limites ao seu exercício.

De fato, ainda que seja desejável a vigência da liberdade em matéria probatória a fim de se buscar a verdade processualmente atingível, tal liberdade necessita ser limitada com a imposição de parâmetros para o seu bom exercício. Dentre essas limitações, como será visto, estão as provas ilícitas.

Assim, se por um lado as provas ilícitas constituem uma importante exceção ao direito à prova, que deve ser o mais amplo possível, por outro se apresentam como sendo uma garantia imprescindível ao resguardo dos direitos fundamentais, ao ser vedada a sua admissibilidade no processo como meio de prova.

Fabricio Guariglia ${ }^{90}$ retrata as regras referentes à obtenção e coleta de prova como autorizações para que o Estado, no curso da investigação e do processo penal interfira na

\footnotetext{
${ }^{89}$ ÁVILA, Thiago André Pierobom. Provas ilícitas e Proporcionalidade, p. 95.
} 
esfera de direitos dos indivíduos com o fim de averiguar a verdade dos fatos narrados nos autos. Conforme seu entendimento tais regras fundadas no princípio da reserva legal estabelecem os pressupostos de ditas interferências estatais e regulamentam suas modalidades e alcance. Nesse sentido operam como normas limitadoras da produção probatória no âmbito processual.

Por certo, é razoável e necessária a imposição de regramentos e limites à busca da verdade, com vistas a compatibilizar direitos, interesses e bens jurídicos conflitantes em jogo.

É que a verdade processualmente atingível e o exercício do direito à prova não constituem valores absolutos e, por isso, não devem ser investigados a qualquer preço, especialmente quando tal fato implicar o sacrifício de direitos fundamentais.

Como ponto de partida às limitações probatórias e a busca da verdade pode-se salientar que ao juiz não é possível fazer uma observação direta dos fatos narrados em juízo. É que a atividade judicial, como já mencionado, vai se desenvolver em cima de fatos passados, que nunca poderão ser reproduzidos em sua totalidade, como efetivamente ocorreram, com riqueza de detalhes e objetividade, por uma impossibilidade lógica ${ }^{91}$.

Aliás, como bem lembra Antonio Magalhães Gomes Filho ${ }^{92}$, ainda que o juiz do feito tivesse presenciado os fatos trazidos a sua análise, estaria ele impedido de apreciar a causa, por ter sido testemunha dos mesmos. É que o juiz só pode julgar com base naquilo que se encontra nos autos e não a partir de suas próprias impressões. O julgador deve, por premissa, ser imparcial na apreciação do feito.

Ademais, podem ser colocadas também como limites à busca da verdade no processo penal a questão da admissibilidade do meio de prova, a sua pertinência e relevância para o caso sub judice $e^{93}$.

Segundo classificação desenvolvida por Eugenio Florian ${ }^{94}$ as restrições à liberdade probatória se dividem em limitações absolutas e limitações relativas. As primeiras se

90 GUARIGLIA, Fabricio. Concepto, fin y alcance de las prohibiciones de valoración probatoria en el procedimiento penal: Una propuesta de fundamentación. Buenos Aires: Del Puerto, 2005, p. 25.

91 JÚNIOR, Aury Lopes. Direito Processual Penal e sua Conformidade Constitucional. v. II, p. 521.

92 Sobre o direito à prova no processo penal, p. 36.

93 Conforme classificação sugerida por GOMES FILHO, Antonio Magalhães. Sobre o direito à prova no processo penal, p. 89 ss.

${ }^{94}$ De las pruebas penales. tomo I, p. 102. 
referem aos casos em que a prova é impedida de ser produzida tendo-se em conta a defesa de bens jurídicos considerados mais relevantes do que o direito de fazer prova no curso de um processo. Já as limitações relativas pró́bem que um fato seja provado a partir de certos meios de prova ou, por outro lado, determinam que o fato narrado no curso do processo seja provado apenas por certo meio de prova.

Tal concepção estava já presente em Ernst Beling ${ }^{95}$ sob a conceituação de proibições probatórias absolutas e proibições probatórias relativas.

Franco Cordero ${ }^{96}$, por sua vez, defende que a inadmissibilidade de valoração probatória pode ter distintas motivações. A prova poderá ser inadmissível nos autos em razão do tema probando, em função da pessoa que se constitui em fonte de prova no caso concreto ou ainda por conta do meio de prova utilizado.

Nas palavras de Hélio Bastos Tornaghi “as limitações ao princípio da liberdade de prova baseiam-se no fato de a lei considerar certos interesses de maior valor que o da prova de um fato, ainda que ele seja ilícito. Razão de política criminal ou processual". ${ }^{97}$ Segundo o mesmo autor as restrições à atividade probatória podem ter por fundamento o sujeito que traz o referido elemento de prova para os autos e a relação que tenha com as partes (como ocorre nos artigos $206^{98}$ e $207^{99}$ do atual Código de Processo Penal brasileiro), o objeto de prova ou ainda a idoneidade do meio para $\operatorname{provar}^{100}$.

Conforme classificação de Antonio Magalhães Gomes Filho ${ }^{101}$, os limites à liberdade probatória possuem também origens distintas. Podem ser de ordem extraprocessual (ou política), como ocorre com os privilégios e com a proibição da admissão de provas obtidas por meios ilícitos (em violação aos direitos fundamentais do indivíduo), ou ainda de ordem

\footnotetext{
${ }^{95}$ Vide nesse sentido: BELING, Ernst; AMBOS, Kai; GUERRERO, Óscar Julián. Las prohibiciones probatorias. Bogotá: Editorial Temis S.A., 2009, p. 05.

${ }^{96}$ CORDERO, Franco. Tre studi sulle prove penali. Milano: Giuffrè, 1963, p. 61.

97 TORNAGHI, Hélio Bastos. Curso de Processo Penal. São Paulo: Editora Saraiva, 1991. v. I, p. 302.

98 “Artigo 206 do CPP: A testemunha não poderá eximir-se da obrigação de depor. Poderão, entretanto, recusarse a fazê-lo o ascendente ou descendente, o afim em linha reta, o cônjuge, ainda que desquitado, o irmão e o pai, a mãe, ou o filho adotivo do acusado, salvo quando não for possível, por outro modo, obter-se ou integrar-se a prova do fato e de suas circunstâncias".

99 "Artigo 207 do CPP: São proibidas de depor as pessoas que, em razão de função, ministério, ofício ou profissão, devam guardar segredo, salvo se, desobrigadas pela parte interessada, quiserem dar o seu testemunho".

${ }^{100}$ Conforme TORNAGHI, Hélio Bastos. Curso de Processo Penal. v. I, p. 294-295.

${ }^{101}$ GOMES FILHO, Antonio Magalhães. Sobre o direito à prova no processo penal, p. 91.
} 
processual (também chamada de ordem lógica ou epistemológica), com a exclusão de provas impertinentes ou irrelevantes para o caso em análise.

As exclusões de provas por motivos processuais têm como finalidade possibilitar uma melhor avaliação pelo julgador acerca dos fatos trazidos para os autos, a fim de evitar decisões arriscadas (ou, em última análise, injustas). Essas regras visam que as provas juntadas aos autos sejam o mais próximas da realidade dos fatos possível e que apenas sejam considerados os elementos de provas que efetivamente sejam úteis a formação da decisão judicial (provas pertinentes e relevantes para o caso) ${ }^{102}$.

Para ilustrar tal modalidade de limite à produção probatória pode-se citar o artigo 158 do Código de Processo Penal brasileiro ${ }^{103}$, que exige a produção de prova técnica na apuração de infrações penais que deixam vestígios materiais. Se, entretanto, os vestígios tiverem já desaparecidos quando da notícia do crime ou não puderem ser encontrados pelos agentes policiais estará autorizada a realização do exame de corpo de delito indireto. Assim, se por um lado é afastada a confissão como meio de prova apto a provar que o referido fato criminoso deveras tenha ocorrido, restringindo-se sob esse aspecto as possibilidades de busca da verdade e a liberdade probatória da parte, por outro se pretende com isso garantir que a "prova da materialidade delitiva" seja a mais crível e robusta possível.

Outros exemplos de restrições da mesma natureza estão presentes nos artigos 155, $\S$ único $^{104}$ e artigo $62^{105}$ ambos do estatuto processual penal brasileiro. Também as previsões constantes dos artigos $208^{106}$ e artigo 232, § único ${ }^{107}$, a contrario sensu, ambos do CPP de 1941 vêm no sentido de que o julgador analise com parcimônia esses meios de prova

\footnotetext{
${ }^{102}$ É preciso notar que apenas serão inadmissíveis pelo juízo os meios de prova que sejam manifestamente supérfluos ou irrelevantes, sob pena de se incorrer em restrições probatórias indevidas. Nesse sentido DALIA, Andrea Antonio; FERRAIOLI, Marzia. Manuale di Diritto Processuale Penale, p. 205-206.

103 “Artigo 158 do CPP. Quando a infração deixar vestígios, será indispensável o exame de corpo de delito, direto ou indireto, não podendo supri-lo a confissão do acusado."

104 “Artigo 155 do CPP: O juiz formará sua convicção pela livre apreciação da prova produzida em contraditório judicial, não podendo fundamentar sua decisão exclusivamente nos elementos informativos colhidos na investigação, ressalvadas as provas cautelares, não repetíveis e antecipadas.

Parágrafo único. Somente quanto ao estado das pessoas serão observadas as restrições estabelecidas na lei civil".

105 "Artigo 62 do CPP: No caso de morte do acusado, o juiz somente à vista da certidão de óbito, e depois de ouvido o Ministério Público, declarará extinta a punibilidade".

106 “Artigo 208 do CPP: Não se deferirá o compromisso a que alude o art. 203 aos doentes e deficientes mentais e aos menores de 14 (quatorze) anos, nem às pessoas a que se refere o art. 206".

107 "Artigo 232 do CPP: Consideram-se documentos quaisquer escritos, instrumentos ou papéis, públicos ou particulares.

Parágrafo único. À fotografia do documento, devidamente autenticada, se dará o mesmo valor do original”.
} 
com relação ao grau de credibilidade ou correlação com a verdade dos elementos de prova que inserem nos autos.

Vale notar que no caso dos artigos 208 e 232, § único do CPP, que tratam, respectivamente, dos testemunhos de incapazes civis e da juntada de cópias de documentos não autenticadas, os elementos de prova chegam a ingressar nos autos e são valorados pelo juízo, sendo certo, entretanto, que o magistrado deverá avaliá-los cuidadosamente em conjunto com o restante do material probatório constante dos autos ${ }^{108}$.

Com relação à exclusão de provas determinada por razões extraprocessuais é preciso ressaltar que tal escolha do sistema se dá em razão da constatação de que o objetivo de apurar a verdade processualmente atingível deve conviver com demais bens e interesses dignos de tutela jurídica pelo ordenamento.

Assim, o limite à atividade probatória é legitimado pela tutela de outros valores dignos de proteção constitucional especial.

Fatores externos ao processo, da mais alta relevância para a vida em sociedade, vão legitimar certo sacrifício ao ideal de busca da verdade no caso concreto. São regras que, de um modo geral, impedem o ingresso nos autos do processo e a valoração de elementos de prova obtidos a partir de violações aos bens jurídicos mais caros aos indivíduos, tais como sua integridade física ou psíquica, sua dignidade, liberdade ou privacidade, ou até mesmo em relação à própria estabilidade das relações sociais e a segurança do Estado.

Nas palavras de Antonio Magalhães Gomes Filho essas regras de exclusão de provas buscam "preservar a esfera individual contra intromissões que, embora ditadas pelo interesse de eficiência do processo, poderiam ter um custo desproporcional, na ótica de uma organização social secularmente assentada na primazia do indivíduo". ${ }^{109}$

Os privilégios mais conhecidos referem-se às vedações aos testemunhos de pessoas que em função da profissão ou ofício desenvolvido obtiveram conhecimento do fato probando, bem como de parentes da parte que podem, em determinadas situações, recusaremse a testemunhar, conforme dispõem respectivamente os artigos 207 e artigo $206^{110}$ do Código de Processo Penal brasileiro.

${ }^{108}$ Exemplos trazidos por GOMES FILHO, Antonio Magalhães. Sobre o direito à prova no processo penal, $\mathrm{p}$. 96-97.

${ }^{109}$ GOMES FILHO, Antonio Magalhães. Sobre o direito à prova no processo penal, p. 99.

${ }^{110}$ Ambos os dispositivos encontram-se já transcritos no trabalho. 
Mas, certamente, o maior expoente desse conjunto de regras de exclusão de provas por razões extraprocessuais encontra-se nas chamadas provas ilícitas, objeto de estudo deste trabalho.

Porém, antes de seguir, convém abordar a relação existente entre eficiência e garantismo no Processo Penal, que permeia o pensamento de Antonio Magalhães Gomes Filho, acima exposto.

\subsection{Eficiência e garantismo e as provas ilícitas}

Conforme sustenta Antonio Scarance Fernandes, o processo penal no mundo todo e também no Brasil apenas será considerado eficiente e terá efetividade se for respeitador dos direitos e garantias fundamentais. É que, segundo sustenta o referido autor, o sistema processual penal deve ser pautado no equilíbrio entre eficiência e garantismo. Não deve haver uma busca incansável por condenações a qualquer custo e nem tampouco um sistema que impossibilite a efetivação da lei penal. Deve-se buscar um equilíbrio ${ }^{111}$.

Essa abordagem pautada por uma análise racional do caso concreto e a busca de um equilíbrio entre eficiência e garantismo deve iluminar também as considerações acerca das provas obtidas por meios ilícitos direta ou indiretamente.

De acordo com o autor o "garantismo no processo penal representa a efetivação do devido processo legal nos prismas subjetivo e objetivo, como garantia das partes, essencialmente do acusado, e como garantias do justo processo". ${ }^{112}$

Eficiente, por sua vez, será o processo que obtiver em um tempo razoável um resultado justo, "seja possibilitando aos órgãos da persecução penal agir para fazer atuar o direito punitivo, seja assegurando ao acusado as garantias do processo legal". ${ }^{113}$

\footnotetext{
${ }^{111}$ FERNANDES, Antonio Scarance. O equilíbrio na repressão ao crime organizado. In: FERNANDES, Antonio Scarance; ALMEIDA, José Raul Gavião de; MORAES, Maurício Zanoide de (Coords.). Crime Organizado Aspectos Processuais. São Paulo: Editora Revista dos Tribunais, 2009, p. 9-10.

${ }^{112}$ FERNANDES, Antonio Scarance. Reflexões sobre as noções de eficiência e de garantismo no processo penal. In: FERNANDES, Antonio Scarance; ALMEIDA, José Raul Gavião de; MORAES Maurício Zanoide de (Coords.). Sigilo no Processo Penal: eficiência e garantismo. São Paulo: Editora Revista dos Tribunais, 2008, p. 16.
} 
Assim, tendo em vista ser o processo uma entidade complexa, formada por uma relação jurídica e por um procedimento, também a eficiência do processo deverá ser analisada quanto a esses dois elementos que o compõem. Conforme Antonio Scarance Fernandes "a eficiência da relação jurídica leva em conta principalmente a eficiência na atuação dos sujeitos processuais (...). Já a eficiência do procedimento resulta da eficiência dos atos que o compõem, quando vistos principalmente na seqüência que devem seguir". ${ }^{114}$

Com relação à finalidade do processo, a análise em relação a sua eficiência depende de qual escopo processual se tem em mente.

Adotando-se, mais uma vez a idéia de equilíbrio entre eficiência e garantismo veiculada por Antonio Scarance Fernandes, a finalidade atribuída ao processo penal deve ser, nas palavras do autor, a de "obtenção de um resultado justo que se legitime pelo procedimento adequado", ou seja, deve-se primar pela concretização do devido processo legal que "assegure a ambas as partes os exercícios de seus direitos e as proteja com as garantias constitucionais". ${ }^{115}$ Isto implica dizer que há que se garantir às partes no processo o direito de apenas terem produzidas contra si provas conforme o Direito, ou seja, provas legais.

De fato, o sistema processual penal deve buscar a efetividade a partir da adoção de mecanismos eficientes e a obtenção de resultados eficazes ${ }^{116}$. Entretanto, isso apenas será possível se os direitos fundamentais dos indivíduos forem respeitados por se tratar de premissa básica em um Estado que se pretenda ser de Direito e Democrático.

Dentre esses direitos está, de maneira especial para este trabalho, o direito à obtenção de provas conforme os ditames legais e constitucionais.

A vedação à utilização da prova ilícita atua como limitador da busca da verdade dos fatos trazidos à judice. Por outro lado, trata-se de regra essencial para a promoção e

${ }^{113}$ FERNANDES, Antonio Scarance. Reflexões sobre as noções de eficiência e de garantismo no processo penal, p. 16.

${ }^{114}$ FERNANDES, Antonio Scarance. Reflexões sobre as noções de eficiência e de garantismo no processo penal, p. 24.

${ }^{115}$ FERNANDES, Antonio Scarance. Reflexões sobre as noções de eficiência e de garantismo no processo penal, p. 24-25.

${ }_{116}$ Conforme, FERNANDES, Antonio Scarance. Reflexões sobre as noções de eficiência e de garantismo no processo penal, p. 17 é importante distinguir eficiência, de eficácia e de efetividade."Eficiência é a ação, força, virtude de produzir efeito; a eficácia é a qualidade ou propriedade de produzir o efeito desejado, de dar um bom resultado; e efetividade é a qualidade daquilo que se manifesta por um efeito real, positivo, seguro, firme, que mereça confiança." 
preservação dos direitos fundamentais dos indivíduos. Nesse sentido traduz com exatidão a busca por equilíbrio entre eficiência e garantismo que deve vigorar no direito processual penal.

\subsection{Defeitos dos atos jurídicos. Distinções entre o regime das nulidades processuais e a inadmissibilidade de provas}

Usualmente os atos processuais imperfeitos são classificados nas seguintes categorias: meras irregularidades, nulidade relativa, nulidade absoluta e inexistência ${ }^{117}$. Além desses tratar-se-á também dos inadmissíveis.

Os atos meramente irregulares são aqueles praticados com defeitos de mínima ou nenhuma relevância, que não afetam em nada a validade do ato.

Já os atos inexistentes, por outro lado, são aqueles concebidos com a falta de algum elemento essencial que acaba por impedir o seu próprio ingresso no mundo jurídico. Não se discute aqui a validade ou não do ato pois o defeito da inexistência constituiu-se em antecedente lógico da produção de efeitos ${ }^{118}$.

No que tange a invalidade dos atos, a doutrina diferencia a nulidade absoluta da nulidade relativa. Tal classificação se apresenta absolutamente controversa no âmbito processual penal por razões que não cabem ser aduzidas nesse momento ${ }^{119}$. De qualquer modo será feita a apresentação sucinta dessas distintas classes de defeitos jurídicos.

A nulidade absoluta se verificaria no caso de uma violação de norma cogente, que tutele o interesse público. Pode ser declarada pelas partes ou de ofício e a qualquer tempo, sendo insanável. Já a nulidade relativa, por sua vez, ocorre com a transgressão de uma norma que tutele um interesse privado. Não pode ser conhecida de ofício pelo juiz, devendo ser alegada pela parte prejudicada ao momento certo, sob pena de preclusão temporal.

\footnotetext{
${ }_{117}$ Conforme JÚNIOR, Aury Lopes. Direito Processual Penal e sua Conformidade Constitucional. v. II, p. 418.

118 GRINOVER, Ada Pellegrini; FERNANDES, Antonio Scarance; GOMES FILHO, Antonio Magalhães. As Nulidades no Processo Penal, p. 20.

119 Favoráveis a aplicação da classificação dos atos com defeitos de validade em absolutamente nulos ou relativamente nulos vide: GRINOVER, Ada Pellegrini; FERNANDES, Antonio Scarance; GOMES FILHO, Antonio Magalhães. As Nulidades no Processo Penal, p. 22. Em sentido oposto, para as críticas feitas à classificação dos atos defeituosos em absolutamente nulos ou relativamente nulos no âmbito processual penal vide: JÚNIOR, Aury Lopes. Direito Processual Penal e sua Conformidade Constitucional. v. II, p. $422-429$.
} 
Assim, como já assinalado oportunamente, o regime das nulidades processuais não se confunde com o sistema da inadmissibilidade apregoado na Constituição Federal no artigo $5^{\circ}$, inciso LVI.

De fato, os atos praticados em contrariedade com a lei podem ser analisados de uma perspectiva ex ante, ou seja, antes de ingressarem nos autos ou ex post, após serem produzidos e inseridos no processo.

O sistema das nulidades impõe a análise pelos sujeitos do processo do ato praticado quanto a sua regularidade formal ou não, após sua introdução nos autos. Ademais, enquanto o ato não é julgado nulo, permanece produzindo seus efeitos jurídicos.

Conforme afirma Luiz Flávio Gomes: "Considerando-se que a nulidade ora é absoluta ora é relativa, pode ser que o julgamento (ex post) acabe (inclusive) por concluir pela irregularidade do ato processual (ou probatório), porém, sem retirar-lhe qualquer eficácia (ex.: nulidade relativa não argüida tempestivamente e que não tenha causado nenhum prejuízo)". ${ }^{120}$

Já o sistema da inadmissibilidade da prova, acolhido pelo legislador constituinte brasileiro no artigo $5^{\circ}$, inciso LVI, da $\mathrm{CF}$, difere das regras relativas à nulidade processual no sentido de que veda a própria introdução das provas consideradas ilícitas nos autos do processo. Assim, em sendo inadmissíveis pela Lei Maior, as provas ilícitas constituem na verdade um “não-ato", aproximando-se da inexistência jurídica ${ }^{121}$.

Conforme ensinamento de Antonio Magalhães Gomes Filho, a admissibilidade da prova trata-se de "um conceito de direito processual e consiste numa valoração prévia feita pelo legislador, destinada a evitar que elementos provenientes de fontes espúrias, ou meios de prova reputados inidôneos, tenham ingresso no processo e sejam considerados pelo juiz na reconstrução dos fatos; daí sua habitual formulação em termos negativos: inadmissibilidade, proibição de prova, exclusionary rules" ${ }^{\prime 22}$.

Assim, enquanto a nulidade pretende retirar a eficácia de uma prova, a inadmissibilidade orienta-se no sentido de impedir seu ingresso no processo. Caso essas

${ }^{120}$ GOMES, Luiz Flávio. Prova ilícita: direito à exclusão dos autos do processo ("exclusionary rule"). Disponível em: 〈http://www.lfg.com.br/public html/article.php?story=20041008122122480p >. Acesso em: 15 set. 2010.

${ }^{121}$ GRINOVER, Ada Pellegrini; FERNANDES, Antonio Scarance; GOMES FILHO, Antonio Magalhães. As Nulidades no Processo Penal, p. 170-171.

${ }^{122}$ GOMES FILHO, Antonio Magalhães. Sobre o direito à prova no processo penal, p. 94. 
provas sejam equivocadamente admitidas deverão ser desentranhadas não sendo consideradas no julgamento da causa.

Luiz Flávio Gomes a esse respeito assim se manifesta: "Se bem compreendida a regra (constitucional) da inadmissibilidade da prova ilícita logo se verifica que jamais seu substractum material (ressalvada a prova ilícita pro reo) pode permanecer nos autos do processo. A consequiência primeira (e mais irrefutável) do reconhecimento da ilicitude de uma prova consiste em sua (incontestável) exclusão dos autos do processo". E continua o autor: "No processo penal democrático (e de partes), regido por todas as garantias do fair trial (do justo processo), ao direito à prova (...) corresponde o direito à exclusão da prova ilícita" ${ }^{223}$.

Portanto, se a sentença judicial houver se embasado em prova obtida por meios ilícitos ou em provas dela decorrentes, deverá o Tribunal em sede de recurso desconsiderá-las, determinando seu desentranhamento e proferindo novo julgamento ${ }^{124}$.

No caso de decisão com trânsito em julgado será esta passível de desconstituição por meio de revisão criminal, de modo que a prova considerada ilícita, bem como as demais provas dela derivadas, não sejam nunca invocadas como razão de decidir ${ }^{125}$.

Entretanto, cumpre destacar, por oportuno, que conforme entendimento solidificado no Supremo Tribunal Federal ${ }^{126}$ caso não sejam as provas ilícitas (iniciais e derivadas) as únicas produzidas nos autos em desfavor do acusado, a condenação do agente deverá ser mantida. Ou seja, existindo nos autos do processo elementos de prova em desfavor do réu e que não derivem direta ou indiretamente da prova ilícita original, poderão estes ser considerados suficientes para sustentar a ação penal e até mesmo fundamentar a condenação do indivíduo ${ }^{127}$.

${ }^{123}$ GOMES, Luiz Flávio. Prova ilícita: direito à exclusão dos autos do processo ("exclusionary rule"). Disponível em: <http://www.lfg.com.br/public_html/article.php?story=20041008122122480p >.Acesso em: 15 set. 2010.

${ }^{124}$ GRINOVER, Ada Pellegrini; FERNANDES, Antonio Scarance; GOMES FILHO, Antonio Magalhães. As Nulidades no Processo Penal, p. 171. Em sentido contrário, sustentando que deverá o Tribunal anular a sentença, determinar o desentranhamento da prova e o retorno dos autos à primeira instância para que seja proferida nova sentença, sob pena de incorrer em supressão de instância, vide: BARROSO, Marcelo Lopes. Reformas no Processo Penal. Fortaleza: Editora Realce, 2009, p. 101.

${ }^{125}$ GRINOVER, Ada Pellegrini; FERNANDES, Antonio Scarance; GOMES FILHO, Antonio Magalhães. As Nulidades no Processo Penal, p. 171.

${ }^{126}$ STF RHC 74.807 MT, Relator Ministro Maurício Corrêa, DJ 20.06.1997; STF HC ED 84.679 MS Relator Ministro Eros Grau, DJ 30.09.2005; STF HC 77.147 BA, Relator Ministro Néri da Silveira, DJ 06.04.2001.

${ }^{127}$ GOMES, Luiz Flávio; CUNHA, Rogério Sanches; PINTO, Ronaldo Batista. Comentários às Reformas do Código de Processo Penal e da Lei de Trânsito. São Paulo: Editora Revista dos Tribunais, 2008, p. 286-287; PRADO, Leandro Cadenas. Provas Ilícitas: Teoria e Interpretação dos Tribunais Superiores. 2. ed. Niterói: 


\subsection{Correntes acerca da ilicitude probatória}

Existem duas correntes principais acerca da ilicitude probatória, a fundamentar, de maneira geral, o tratamento dispensado à prova ilícita nos diferentes ordenamentos jurídicos ao redor do globo ${ }^{128}$.

Para uma primeira linha de pensamento, a liberdade probatória abrangeria qualquer meio de prova, independentemente da forma de obtenção dos elementos probatórios. Segundo tal ponto de vista, eventuais transgressões às regras de direito material não comprometeriam o grau de veracidade das informações trazidas aos autos pela prova ilícita. Assim, provas obtidas ilicitamente seriam perfeitamente admissíveis no processo, sem prejuízo das sanções em âmbito civil, administrativo ou penal, eventualmente aplicáveis ao infrator $^{129}$.

Trata-se da máxima male captum, bene retentum, segundo a qual o que foi mal colhido no momento material (prova obtida ilicitamente) teria sido bem conservado, no momento processual, possibilitando seu ingresso nos autos do processo ${ }^{130}$. Tal visão tem por pressuposto a independência das esferas do direito material e processual.

De acordo com esse pensamento, a ilicitude da prova só acarretaria sua inadmissibilidade no processo se, no caso concreto, acabasse por violar também uma regra de direito processual, tornando-a ilegítima.

De fato, a admissibilidade da prova não diz respeito à maneira pela qual uma determinada prova foi obtida. Segundo essa corrente, o importante é atentar-se para o fato de ser sua introdução no processo consentida ou não, pois a admissibilidade das provas será determinada pela lei processual. Ou seja, quem agiu em contrariedade ao direito deverá ser

Editora Impetus, 2009, p. 22 e JÚNIOR, Aury Lopes. Direito Processual Penal e sua Conformidade Constitucional. v. I, p. 595-596.

${ }^{128}$ Ressalte-se tratar-se de uma classificação que divide os países em dois grandes grupos em relação ao tratamento conferido à temática da prova ilícita, sem levar em conta as especificidades de cada sistema. Uma abordagem mais detalhada em relação a alguns países selecionados -aqueles que exercem maior influência sobre o ordenamento jurídico brasileiro - será realizada no próximo capítulo.

${ }^{129}$ ÁVILA, Thiago André Pierobom. Provas ilícitas e Proporcionalidade, p. 92-93.

${ }^{130}$ CASTRO, Raimundo Amorim de. Provas Ilícitas e o Sigilo das Comunicações Telefônicas. Curitiba: Editora Juruá, 2008, p. 86. 
punido, mas a prova obtida, a despeito da ilegalidade cometida será valida, podendo ser introduzida no processo toda vez que a lei processual não o vede de forma expressa. Portanto, se o direito processual não vedar a utilização da prova obtida a partir de um ato ilícito, não haverá como rechaçar-se tal prova. ${ }^{131}$

Essa corrente doutrinária, a despeito de eventuais variações ${ }^{132}$, é a predominante no sistema da Common Law (com exceção dos Estados Unidos). Encontra-se atualmente um tanto mitigada na Inglaterra, mas ainda com forte predomínio no Canadá, na Austrália e na África do Sul.

Luiz Francisco Torquato Avolio, explanando tal pensamento doutrinário afirma que, de acordo com essa teoria "a prova obtida ilicitamente deveria ser válida e eficaz, sem prejuízo das sanções cabíveis aos responsáveis - policiais ou particulares - por sua obtenção. (...) Prescindir de provas formalmente corretas pela tão-só existência de fraude em sua obtenção seria prescindir voluntariamente de elementos de convicção relevantes para o justo resultado do processo". 133

Trata-se de uma concepção de processo segundo o qual a busca da verdade seria seu principal escopo, inserindo a reconstrução da realidade como princípio inspirador e motivador do processo penal.

Por outro lado, nos países de Civil Law, de um modo geral, e também nos Estados Unidos da América, o sistema dominante apregoa a inadmissibilidade das provas obtidas por meios ilícitos no processo, como forma de melhor tutelar os direitos fundamentais dos indivíduos, dentre outras finalidades.

A exclusão das provas consideradas ilícitas com a determinação, a priori, de sua inadmissibilidade, busca desencorajar as instâncias responsáveis pela repressão ao crime de se valerem de subterfúgios violadores de direitos dos cidadãos, especialmente dos direitos à intimidade e do direito à integridade física e moral dos indivíduos.

Além disso, essas conclusões parecem advir de um raciocínio lógico segundo o qual não seria ético que o Estado operasse o combate à criminalidade praticando atos ilegais

\footnotetext{
${ }^{131}$ GRINOVER, Ada Pellegrini. Liberdades Públicas e Processo Penal: as interceptações telefônicas, p. 105.

132 GRINOVER, Ada Pellegrini. Liberdades Públicas e Processo Penal: as interceptações telefônicas, p. 104108.

${ }^{133}$ AVOLIO, Luiz Francisco Torquato. Provas ilícitas: Interceptações telefônicas, ambientais e gravações clandestinas, p. 44.
} 
para tanto, sendo cometidos em alguns casos até mesmo atos criminosos (violação de sigilos de correspondência ou telefônicos sem a devida autorização, invasão de domicílios etc.) na busca por fontes de prova ${ }^{134}$.

É também neste sentido o pensamento de Christian Sthefan Simons. Segundo o autor "a questão da prevalência ética da atuação estatal impõe a inadmissibilidade da prova ilícita no processo penal devido à superioridade ética do Estado no combate à criminalidade". ${ }^{135}$ De fato, o Estado tem sua atividade persecutória limitada, em razão do compromisso firmado com a sociedade que o compõe, de desenvolver um comportamento ético, reconhecedor de que em inúmeros casos é necessário que outros direitos igualmente importantes prevaleçam em relação à atividade persecutória do Estado.

O Brasil adota por expressa previsão constitucional a segunda teoria apresentada, apregoando a inadmissibilidade das provas obtidas de maneira ilícita nos autos do processo.

Porém, antes de adentrar na análise do sistema brasileiro, convém fazer um breve estudo acerca do direito comparado, analisando o tratamento dispensado à prova ilícita em diferentes ordenamentos jurídicos estrangeiros, especialmente no que tange à prova ilícita por derivação, com vistas a melhor compreender o sistema pátrio.

${ }^{134}$ GRINOVER, Ada Pellegrini. Liberdades Públicas e Processo Penal: as interceptações telefônicas, p. 108111.

${ }^{135}$ SIMONS, Christian Sthefan. A prova ilícita no direito processual penal norte-americano e alemão e as influências no processo penal brasileiro, p. 108. 


\section{A PROVA ILÍCITA NO DIREITO COMPARADO}

De forma sucinta será feita uma análise do tratamento dispensado às provas ilícitas - em especial no tocante à ilicitude por derivação - nos ordenamentos jurídicos dos Estados Unidos da América, da Alemanha, de Portugal, da Espanha, da Itália e da Inglaterra.

Com relação a Inglaterra trata-se de um representante atual da teoria do male captum, bene retentum, com algumas mitigações em relação a idéia original.

Já os demais países abordados exerceram - e ainda exercem - grande influência sobre o ordenamento processual penal brasileiro no que tange a questão da prova ilícita e em particular em relação às provas ilícitas por derivação.

Como será visto, as provas ilícitas por derivação - desenvolvidas inicialmente nos Estados Unidos - recebem tratamento distinto nos países retratados, predominando em alguns a aceitação da ilicitude por derivação quase sem mitigações à regra e em outros países sendo tal doutrina praticamente rechaçada.

\subsection{Prova ilícita nos Estados Unidos}

País adepto do sistema da Common law, ao contrário dos demais, em que vigora a regra da admissibilidade da prova independente da forma como foi obtida ${ }^{136}$, nos Estados Unidos a Jurisprudência da Suprema Corte desenvolveu com base nos precedentes judiciais as chamadas exclusionary rules.

As regras de exclusão determinam a inadmissibilidade nos autos do processo de provas obtidas com violação às Emendas Constitucionais de números IV, V, VI e XIV. Assim, de acordo com tal regra deverão ser excluídas do processo provas obtidas em violação aos direitos garantidos pela Constituição Norte-Americana, antes do julgamento do caso em questão.

136 ÁVILA, Thiago André Pierobom. Provas ilícitas e Proporcionalidade, p. 135. 
As exclusionary rules foram inicialmente pensadas com vistas a desestimular a conduta de policiais que no exercício da atividade de investigação praticavam atos ofensivos a direitos constitucionais. Entendia-se que eventuais sanções nas esferas cível, administrativa e penal não eram suficientes para impedir o desrespeito a tais direitos pelos agentes policiais.

Assim, as exclusionary rules teriam como função primordial evitar a atuação ilegal dos policiais e, indiretamente, resguardar direitos fundamentais, consubstanciados nas Emendas Constitucionais, especialmente no que diz respeito à Quarta Emenda. Tanto é assim que provas ilícitas obtidas nos Estados Unidos por particulares não são excluídas dos autos, ressalvados os casos em que estes atuam a mando de agentes policiais ${ }^{137}$.

No que tange às exclusões de prova desenvolvidas em proteção ao quanto disposto na Quinta Emenda, teriam surgido inicialmente como um caso de exclusão fundado no caráter pouco confiável do meio de prova e só posteriormente a Corte Suprema teria se inclinado no sentido de, com essa exclusão, efetivamente tutelar direitos fundamentais ${ }^{138}$.

A Quarta Emenda à Constituição Norte-Americana ${ }^{139}$ trata do direito a privacidade. De acordo com o texto constitucional o direito do povo à inviolabilidade de suas pessoas, casas, documentos e haveres contra buscas e apreensões desarrazoadas, não será violado. Determina ainda que não sejam expedidos mandados a não ser diante de causas prováveis, confirmadas por juramentos ou declarações, e particularmente com a descrição do local da busca e a indicação das pessoas ou coisas a serem apreendidas.

A Quinta Emenda ${ }^{140}$ versa basicamente acerca do direito ao devido processo legal. Trata também do direito do indivíduo de não produzir provas contra $\mathrm{si}^{141} \mathrm{e}$ do direito à

${ }^{137}$ KAMISAR, Yale; LAFAVE, Wayne; ISRAEL, Jerold. Modern Criminal Procedure: Cases Comments and Questions. 8th ed. St. Paul: West Publishing Co, 1994, p. 155.

${ }_{138}$ GUARIGLIA, Fabricio. Concepto, fin y alcance de las prohibiciones de valoración probatoria en el procedimiento penal: Una propuesta de fundamentación, p. 16.

139 "U.S. Constitution: Amendment IV

The right of the people to be secure in their persons, houses, papers, and effects, against unreasonable searches and seizures, shall not be violated, and no warrants shall issue, but upon probable cause, supported by oath or affirmation, and particularly describing the place to be searched, and the persons or things to be seized".

140 "U.S. Constitution: Amendment V

No person shall be held to answer for a capital, or otherwise infamous crime, unless on a presentment or indictment of a Grand Jury, except in cases arising in the land or naval forces, or in the Militia, when in actual service in time of War or public danger; nor shall any person be subject for the same offence to be twice put in jeopardy of life or limb; nor shall be compelled in any criminal case to be a witness against himself, nor be deprived of life, liberty, or property, without due process of law; nor shall private property be taken for public use, without just compensation." 
propriedade privada. Afirma o dispositivo que ninguém será detido para responder por crime, salvo por denúncia ou acusação perante um Grande Júri e com exceção dos casos que ocorram nas forças de terra ou mar, ou na milícia, em tempo de guerra ou de perigo público, durante o serviço ativo. Ademais, garante que ninguém será processado pelo mesmo crime por duas vezes e nem tampouco será obrigado a servir de testemunha contra si mesmo em qualquer processo criminal. A Constituição Norte-Americana prevê ainda que os indivíduos não serão privados de sua vida, liberdade, ou bens, sem o devido processo legal; nem a propriedade privada poderá ser expropriada para uso público, sem justa indenização.

Segundo o quanto estabelecido na Sexta Emenda ${ }^{142}$, em todo e qualquer processo criminal, o acusado terá direito a um julgamento rápido e público, a ser realizado por Júri imparcial do Estado e distrito onde o crime houver sido cometido. Terá ainda o réu o direito a ser informado sobre a natureza e a causa da acusação, a realizar acareação com as testemunhas de acusação, bem como o direito de fazer comparecer, por meios legais, testemunhas de defesa e o direito de ser defendido por um advogado. Esse dispositivo garante, portanto, ao réu um julgamento célere e isento, bem como o direito a defesa técnica.

Por fim, a Décima Quarta Emenda ${ }^{143}$ à Constituição dos EUA, em sua Seção 1, estende a garantia do devido processo legal e demais prescrições do Bill of Rights aos Estados da Federação.

${ }^{141}$ De acordo com KAMISAR, Yale; LAFAVE, Wayne; ISRAEL, Jerold. Modern Criminal Procedure: Cases Comments and Questions, p. 823, a Quinta Emenda à Constituição Norte-Americana garante aos indivíduos a proteção a apenas uma das vertentes do princípio do nemo tenuter se detegere, qual seja, a garantia de que o indivíduo em seu interrogatório não será obrigado a fornecer informações auto-incriminatórias (nemo tenetur se ipsum accusare). Entretanto não protege o acusado do dever de produzir provas não orais contra si próprio (nontestimonial evidence). Nas palavras dos autores: "The Fifht Amendment's mandate that no person 'shall be compelled in any criminal case to be a witness against himself.' That mandate does not protect an accused from being compelled to surrender nontestimonial evidence against himself'.

142 "U.S. Constitution: Amendment VI

In all criminal prosecutions, the accused shall enjoy the right to a speedy and public trial, by an impartial jury of the State and district wherein the crime shall have been committed, which district shall have been previously ascertained by law, and to be informed of the nature and cause of the accusation; to be confronted with the witnesses against him; to have compulsory process for obtaining witnesses in his favor, and to have the Assistance of Counsel for his defence".

143 "U.S. Constitution: Amendment XIV

Section. 1. All persons born or naturalized in the United States and subject to the jurisdiction thereof, are citizens of the United States and of the State wherein they reside. No State shall make or enforce any law which shall abridge the privileges or immunities of citizens of the United States; nor shall any State deprive any person of life, liberty, or property, without due process of law; nor deny to any person within its jurisdiction the equal protection of the laws". 
O primeiro julgamento da Suprema Corte no qual se aventou a possibilidade de exclusão de provas adquiridas com violação da Quinta Emenda foi em Boyd v. United States, em $1886^{144}$.

Em que pese a Corte Superior ter posteriormente mudado seu entendimento em parte $^{145}$, o que sucedeu naquele caso foi o seguinte: "O réu foi obrigado pela corte distrital a apresentar documentos pessoais, sob pena de praticar contempt of court". ${ }^{146} \mathrm{O}$ acusado atendeu ao mandamento, entretanto foi condenado, tendo, portanto, recorrido à Suprema Corte.

O Tribunal máximo do país decidiu que existe distinção entre a busca e apreensão de objetos ligados ao crime e bens pessoais do indivíduo. De fato, a Suprema Corte estabeleceu no caso um vínculo íntimo entre o quanto disposto na Quarta e Quinta Emendas à Constituição. Assim, definiu que a obrigação imposta ao acusado de apresentar objetos pessoais não relacionados com o crime constitui uma busca e apreensão ilegal, em ofensa à Emenda IV. Ademais, concluiu que tal medida implicaria exigir que o acusado produzisse prova contra si, em violação ao privilégio contra a auto-acusação, garantido pela Emenda V. Portanto, a Suprema Corte resolveu submeter o condenado a novo julgamento, determinando a inadmissibilidade dos referidos documentos particulares nos autos do processo.

Em Weeks v. U.S. em $1914^{147}$ deu- se a consagração das exclusionary rules no sistema processual penal estadunidense. Nesse caso, a Suprema Corte constatou a ilegalidade da interceptação e apreensão de correspondência do acusado efetuada sem autorização judicial, em ofensa à Quarta Emenda. Determinou então a exclusão de tais elementos de prova. Entretanto a decisão ficou restrita a atuação de agentes federais, não se aplicando aos estaduais.

\footnotetext{
${ }^{144} 116$ U.S. 616. Disponível em:< http://supreme.justia.com/us/116/616/case.html $>$. Acesso em: 18 mar. 2010.

${ }^{145}$ Conforme afirma RAMOS, José Gualberto Garcez. Curso de Processo Penal norte-americano. São Paulo: Editora Revista dos Tribunais, 2006, p. 123: "Interessante notar que, décadas depois, embora mantivesse intocada a idéia-máter de que a prova ilícita é nula para todos os fins, a Suprema Corte, em Fisher v. United States, 425 US 391 (1976), alterou substancialmente a solução preconizada em Boyd. Em Fischer passou a considerar que a emissão de mandados (...) não atinge o privilégio contra a auto-incriminação forçada".

${ }^{146}$ SIMONS, Christian Sthefan. A prova ilícita no direito processual penal norte-americano e alemão e as influências no processo penal brasileiro, p. 39.

${ }^{147} 232$ U.S. 383. Disponível em: <http://supreme.justia.com/us/232/383/case.html> Acesso em: 18 mar. 2010.
} 
Com o caso Silverthorne Lumber Co. v. United States, de $1920^{148}$, a Corte Suprema criou o sustentáculo da famosa teoria da ilicitude por derivação, conhecida como fruits of the poisonous tree doctrine, em que pese não ter sido ainda cunhada tal expressão naquele julgamento, mas somente em decisão posterior ${ }^{149}$.

Em tal caso, os réus Frederick Silverthorne e seu pai foram presos por desobedecerem à ordem da Corte local, que determinou que eles entregassem ao Júri livros da empresa da qual eram sócios, a fim de fazerem prova contra si. Os acusados invocaram em seu favor o privilégio estabelecido na Emenda V. Após a prisão de ambos, representantes do Departamento de Justiça, valendo-se de tal situação, efetuaram a apreensão dos referidos livros contábeis, sem obter autorização judicial para tanto. Em razão disso, foi determinada a devolução de tais livros. Ocorre que, antes de proceder à devolução de toda documentação, agentes do governo extraíram cópias do material, que foram então utilizadas no processo em desfavor dos acusados.

Levado o caso à análise da Suprema Corte ficou decidido pelo desentranhamento do material dos autos do processo. Ademais sinalizou a Corte no sentido de que a proibição de obtenção de provas em violação às Emendas Constitucionais se estende para as provas não consideradas ilícitas em si, mas derivadas das obtidas com a ilegalidade inicial $^{150}$.

Constou da decisão que a essência da norma que proíbe a aquisição da prova de certa maneira não se limita a dizer que ela não pode ser utilizada em juízo, mas reza que ela não poderá ter efeito algum. Entretanto, conforme ressalva feita na mesma decisão, isso não significaria dizer que as provas obtidas ilegalmente seriam sagradas e inacessíveis ${ }^{151}$.

Portanto no mesmo julgamento em que foram delineadas as origens da teoria da ilicitude por derivação, acenou-se também com a possibilidade de serem aceitas mitigações a

\footnotetext{
${ }^{148} 251$ U.S. 385. Disponível em: <http://supreme.justia.com/us/251/385/case.html>. Acesso em: 18 mar. 2010.

${ }^{149} \mathrm{Tal}$ expressão foi utilizada pelo juiz Frankfurter na apreciação do caso Nardone v. U.S. de 1939 (308 U.S. 338).

${ }^{150}$ Conforme trecho do julgamento: "The essence of a provision forbidding the acquisition of evidence in a certain way is that not merely evidence so acquired shall not be used before the Court, but that it shall not be used at all. Of course, this does not mean that the facts thus obtained become sacred and inaccessible. If knowledge of them is gained from an independent source they may be proved like any others, but the knowledge gained by the Government's own wrong cannot be used by it in the way proposed". (grifo nosso)

${ }^{151}$ RAMOS, José Gualberto Garcez. Curso de Processo Penal norte-americano, p. 123-124.
} 
tal regra, fazendo-se menção expressa ao ideário que ficou posteriormente conhecido como independent source limitation (exceção da fonte independente) ${ }^{152}$.

Foi no caso Nardone v. U.S. ${ }^{153}$ em 1939, que a expressão fruits of the poisonous tree foi utilizada pela primeira vez pela Suprema Corte Norte Americana, tendo sido proferida naquela ocasião pelo juiz Frankfurter.

Em tal episódio o Tribunal entendeu pela exclusão de testemunhos prestados por agentes públicos que haviam conduzido e acompanhado a gravação de conversas decorrentes de interceptação telefônica ilegal do réu, por constituírem provas ilícitas por derivação ${ }^{154}$. Também no mesmo julgamento fez-se menção pela primeira vez a uma possível mitigação a tal teoria da ilicitude derivada a partir do desenvolvimento da idéia de que, se a ilegalidade da prova derivada encontra-se, no caso concreto, já atenuada em relação à ilicitude anterior, tal fato não seria suficiente para justificar a exclusão da segunda prova ${ }^{155}$.

No caso Walder v. United States ${ }^{156}$, em 1954, a Corte estadunidense desenvolveu a exceção à regra de exclusão da prova originalmente ilícita conhecida por impeachment exception (exceção de impugnação). Essa limitação à vedação da prova ilícita no processo visa permitir a inserção nos autos de prova viciada para impugnar a credibilidade das declarações do réu em seu interrogatório ${ }^{157}$. Tal fato decorre da previsão constante do ordenamento do país de que o réu tem direito ao silêncio, mas caso decida falar em juízo não poderá mentir sob pena de praticar o crime de perjúrio. Assim nesse caso seriam admissíveis

\footnotetext{
${ }^{152}$ Neste sentido RAMOS, João Gualberto Garcez. Curso de Processo Penal norte-americano, p. 124, bem como ÁVILA, Thiago André Pierobom. Provas ilícitas e Proporcionalidade, p. 152. Em sentido contrário, SIMONS, Christian Sthefan. A prova ilícita no direito processual penal norte-americano e alemão e as influências no processo penal brasileiro, p. 40 sustenta ter sido desenvolvida no precedente Silverthorne Lumber Co. v. United States, a origem remota da exceção da teoria dos frutos da árvore envenenada chamada de taint doctrine (exceção do vício atenuado).

${ }^{153} 302$ U.S. 338. Disponível em <http://supreme.justia.com/us/302/338/case.html $>$. Acesso em: 18 mar. 2010.

${ }^{154}$ Conforme trecho da decisão: "In a prosecution in a federal court, evidence procured by tapping wires in violation of the Communications Act of 1934 is inadmissible. This applies not only to the intercepted conversations themselves, but also, by implication, to evidence procured through the use of knowledge gained from such conversations" (grifo nosso).

${ }^{155}$ Segundo constou do julgamento: "Sophisticated argument may prove a causal connection between information obtained through illicit wiretapping and the Government's proof. As a matter of good sense, however, such connection may have become so attenuated as to dissipate the taint" (grifo nosso).

${ }^{156} 347$ U.S. 62. Disponível em: 〈http://supreme.justia.com/us/347/62/case.html〉. Acesso em: 28 maio 2010.

${ }^{157}$ BLOOM, Robert; BRODIN, Mark. Criminal Procedure: Examples and Explanatios. 4th ed. New York: Aspen Publishers, 2004, p. 252.
} 
as provas ilícitas apenas para o fim de demonstrar a falta de credibilidade do réu, mas não para provar sua culpabilidade no caso ${ }^{158}$.

Em Mapp v. Ohio, ${ }^{159}$ julgado em 1961, o Tribunal Superior decidiu que as regras de exclusão eram os remédios adequados também para as provas ilícitas produzidas em âmbito estadual ${ }^{160}$. Ou seja, a Corte passou a entender que "a regra de exclusão é parte do princípio do devido processo legal e, enquanto tal, aplicável não somente à União, mas também aos Estados-membros". 161

A Jurisprudência norte-americana desenvolveu a partir do julgamento do caso Wong Sun v. United States ${ }^{162}$, em 1963, a mitigação à teoria da ilicitude por derivação chamada de attenuated connection doctrine ${ }^{163}$ (exceção do nexo causal atenuado), já aventada em Nardone v. U.S e também conhecida como taint doctrine ou purged taint exception (exceção do vício ou mancha diluídos).

No caso Wong Sun v. U.S, policiais que investigavam o tráfico de drogas na região de São Francisco entraram na residência de Hom Way, durante a madrugada e sem mandado judicial, após terem realizado campana no local e terem vigiado Hom por cerca de seis semanas. Os agentes federais prenderam-no por possuir pequena quantidade de heroína em seu poder. Hom Way, após ser preso, declarou que havia comprado um grama da droga na noite anterior de um conhecido seu, que os policiais identificaram como sendo James Wah Toy.

Quando já amanhecia, os policiais adentraram na casa de James Wah Toy novamente sem mandado judicial e com fundamento apenas nas alegações de Hom Way. Efetuaram busca no local, não encontrando ali qualquer substância entorpecente. James esclareceu que não possuía droga consigo, mas sabia quem a teria, indicando então a pessoa de Johnny Yee.

\footnotetext{
${ }_{158}$ ÁVILA, Thiago André Pierobom. Provas ilícitas e Proporcionalidade, p. 148.

159367 U.S. 643. Disponível em: <http://supreme.justia.com/us/367/643/case.html〉. Acesso em: 19 mar. 2010.

${ }^{160}$ KAMISAR, Yale; LAFAVE, Wayne; ISRAEL, Jerold. Modern Criminal Procedure: Cases Comments and Questions, p. 130-135.

${ }_{161}$ RAMOS, José Gualberto Garcez. Curso de Processo Penal norte-americano, p. 124.

162371 U.S. 471. Disponível em: 〈http://supreme.justia.com/us/371/471/case.html〉. Acesso em: 27 maio 2010.

${ }^{163}$ Conforme RAMOS, João Gualberto Garcez. Curso de Processo Penal norte-americano, p. 124, bem como ÁVILA, Thiago André Pierobom. Provas ilícitas e Proporcionalidade, p. 155. Em sentido contrário, SIMONS, Christian Sthefan. A prova ilícita no direito processual penal norte-americano e alemão e as influências no processo penal brasileiro, p. 47 sustenta ter sido aplicada no caso Wong Sun v. United States, a exceção da teoria dos frutos da árvore envenenada chamada de independent source (fonte independente).
} 
Os agentes públicos dirigiram-se até a casa de Johnny Yee onde encontraram certa quantidade de heroína, que foi apreendida e Johnny foi preso.

Yee e Toy foram levados para o Instituto do Departamento de Narcóticos de São Francisco para serem interrogados. Yee, em seu interrogatório afirmou que a heroína encontrada com ele havia lhe sido entregue dias atrás por Toy e outro indivíduo chamado Wong Sun.

Os policiais deslocaram-se até a residência de Wong Sun, nada encontrando no local. Wong Sun foi liberado e em oportunidade posterior retornou ao Departamento Policial, voluntariamente, para prestar novo depoimento, tendo sido advertido na ocasião de seu direito de não produzir provas contra si, de se fazer acompanhar por advogado, dentre outros direitos consubstanciados nos Miranda warnings, mas ainda assim decidiu falar.

Levado o caso à Suprema Corte, esta decidiu pela ilegalidade da prisão de Toy em face da inexistência de razoabilidade para a sua decretação e da falta de mandado judicial naquele sentido. Assim, as declarações feitas por James Wah Toy em seu interrogatório foram excluídas dos autos, por serem fruto de uma prisão ilegal. Conseqüentemente a droga entregue por Johnny Yee à polícia também foi desconsiderada no caso, bem como as informações prestadas por ele em seu interrogatório, tendo em vista estarem viciadas por ilicitude derivada, pois apenas foram descobertas pela polícia em razão das declarações prestadas por Toy. Logo, a prisão de Yee foi também considerada viciada.

Wong Sun, entretanto, foi levado a novo julgamento, no qual foram consideradas válidas as apreensões de entorpecentes realizadas no caso. A Corte entendeu que, em relação a Sun, ao se dispor de forma voluntária a ser interrogado novamente, ele teria atuado no sentido de desfazer o nexo causal entre a ilicitude inicial das provas obtidas no caso concreto e as suas declarações ${ }^{164}$. Nasce então aí a mitigação à teoria da ilicitude derivada chamada de attenuated connection doctrine.

No precedente Chapman v. California ${ }^{165}$, de 1967, desenvolveu-se uma exceção à regra de exclusão de provas ilícitas originárias chamada harmless error exception

\footnotetext{
${ }^{164}$ Conforme constou da decisão: "For Wong Sun's unsigned confession was not the fruit of that arrest, and was therefore properly admitted at trial. On the evidence that Wong Sun had been released on his own recognizance after a lawful arraignment, and had returned voluntarily several days later to make the statement, we hold that the connection between the arrest and the statement had become so attenuated as to dissipate the taint".

165386 U.S. 18. Disponível em: 〈http://supreme.justia.com/us/386/18/case.html〉. Acesso em: 28 maio 2010.
} 
(exceção de erro inócuo), para ser aplicada nos casos em que tivesse ocorrido um erro sem importância durante o procedimento penal e este não tivesse causado lesão relevante aos direitos constitucionais das partes ${ }^{166}$. Aplica-se também essa mitigação nos casos em que a condenação do réu foi embasada por prova que deveria ser excluída dos autos, mas é corroborada por provas admissíveis, mantendo-se o resultado do julgamento.

$\mathrm{Na}$ verdade, em relação ao primeiro uso apontado, essa exceção aproxima-se das regras que versam sobre nulidade de provas ilegítimas no ordenamento brasileiro ${ }^{167}$. Já com relação ao segundo ponto, tal fato é também verificado na Jurisprudência brasileira, conforme mencionado no tópico 1.5 do capítulo anterior.

Foi em Nix v. Williams ${ }^{168}$, em 1984 que se desenvolveu a exceção à aplicação da fruits of the poisonous tree doctrine conhecida como inevitable discovery exception (exceção da descoberta inevitável), chamada também de hypothetical independent source doctrine $^{169}$ (doutrina da fonte independente hipotética).

Segundo tal formulação, demonstrado que no caso concreto a prova ilegal seria, mais cedo ou mais tarde, legalmente descoberta e colhida em razão de investigações já em curso e nas mesmas condições em que o foi em função da ilegalidade praticada, a prova ilícita não seria excluída dos autos, mas levada em conta pelo Júri na decisão do caso ${ }^{170}$.

No caso em questão, uma menina com 10 anos de idade havia desaparecido em Des Moines, Iowa, nos EUA. A polícia encontrou um indivíduo considerado suspeito do referido crime na cidade de Davenport, no mesmo Estado e decidiu levá-lo de volta a Des Moines.

No caminho, um dos policiais deu início a uma conversa informal com o indivíduo que culminou em sua confissão do crime de homicídio praticado contra a criança desaparecida, sem que ele estivesse, no momento da confissão, acompanhado de seu advogado ou houvesse sido advertido de seus direitos, constantes nos Miranda warnings. O suspeito, durante dada conversa, informou aos agentes a localização do corpo da vítima.

\footnotetext{
${ }^{166}$ BLOOM, Robert; BRODIN, Mark. Criminal Procedure: Examples and Explanatios, p. 253.

167 ÁVILA, Thiago André Pierobom. Provas ilícitas e Proporcionalidade, p. 149-150.

168467 U.S. 431. Disponível em: <http://supreme.justia.com/us/467/431/case.html〉. Acesso em 19 mar. 2010.

169 Conforme nomenclatura adotada por RAMOS, José Gualberto Garcez. Curso de Processo Penal norteamericano, p. 124.

${ }^{170}$ Conforme constou do julgamento do precedente: "The Court concludes that unconstitutionally obtained evidence may be admitted at trial if it inevitably would have been discovered in the same condition by an independent line of investigation that was already being pursued when the constitutional violation ocurred".
} 
Naquele exato momento, contudo, estava sendo realizada uma busca sistemática na cidade, conduzida com o auxílio de cerca de duzentos voluntários, e que apenas foi encerrada em razão da informação obtida pelos policiais dando conta do local preciso em que o corpo havia sido ocultado.

Assim, a Corte Suprema estadunidense entendeu que no referido caso, se não tivesse sido interrompida a busca realizada por populares, a localização do corpo teria sido obtida em um curto período de tempo, de forma inevitável e independente da confissão feita pelo indivíduo, em ofensa ao quanto previsto na Sexta Emenda à Constituição.

Ademais, a Corte Suprema considerou que o corpo teria sido encontrado nas mesmas condições de conservação em que o foi tendo em vista o inverno rigoroso que vivenciavam $^{171}$. Portanto decidiu a Corte pela manutenção do laudo acerca da morte da criança nos autos, pois tal elemento de prova não teria sido afetado pela ilegalidade da confissão do réu.

Em United States v. Leon ${ }^{172}$ (1984), a Corte Superior introduziu no ordenamento jurídico norte americano nova mitigação à prova ilícita original chamada good faith exception (exceção da boa-fé policial) ${ }^{173}$.

Nesse caso a Suprema Corte do país reconheceu como válida uma busca e apreensão de certa quantidade de entorpecente realizada por policiais com base em uma autorização judicial, que posteriormente se verificou carente de indícios razoáveis (probable cause). Entendeu o Tribunal que a boa-fé dos policiais, representada pela razoável confiança de que possuíam uma causa provável para a busca e de que portavam um mandado válido justificava o procedimento adotado, não sendo razoável ou sequer necessária a exclusão da $\operatorname{prova}^{174}$.

A partir dessa decisão verifica-se um declínio gradual na adoção da regra de exclusão das provas ilícitas pelos tribunais norte-americanos ${ }^{175}$.

Aliás, como justificativa para a decisão proferida no caso United States v. Leon, a Suprema Corte dos EUA invocou o argumento de que as regras de exclusão teriam como

\footnotetext{
${ }_{171}^{17}$ BLOOM, Robert; BRODIN, Mark. Criminal Procedure: Examples and Explanatios, p. 210.

172468 U.S 897. Disponível em: <http://supreme.justia.com/us/468/897/case.html>. Acesso em: 27 maio 2010.

${ }^{173}$ KAMISAR, Yale; LAFAVE, Wayne; ISRAEL, Jerold. Modern Criminal Procedure: Cases Comments and Questions, p. 135-146.

174 ÁVILA, Thiago André Pierobom. Provas ilícitas e Proporcionalidade, p. 147.

175 ÁVILA, Thiago André Pierobom. Provas ilícitas e Proporcionalidade, p. 147.
} 
finalidade precípua evitar que policiais, no desenvolvimento de suas atividades de investigação, praticassem condutas ofensivas aos direitos fundamentais dos indivíduos. Assim, quando os policiais atuassem de boa-fé, não haveria razão para a exclusão da prova, em que pese fosse verificado no caso a infração de direitos constitucionais.

Conforme explica Thiago André Pierobom de Ávila: “Considerando que a regra de exclusão é vista como um remédio para dissuadir as violações policiais (deterrence of policial misconduct), quando o agente policial atuasse de boa-fé, os custos da aplicação da regra não excederiam seus benefícios, sendo, portanto, admissível a utilização da prova". ${ }^{176}$

Entretanto, de acordo com a Corte Suprema Norte-Americana, a good faith exception não poderá ser aplicada, prevalecendo portanto a regra de exclusão, nos casos em que o policial, de forma intencional ou não, induzir o magistrado em erro ao requerer mandados judiciais; ou ainda na hipótese da autorização judicial ser inválida e tal fato ser de tão óbvia constatação que não se possa considerar que algum agente policial poderia acreditar que o mandado obtido fosse válido e regular; bem como no caso de autorizações judiciais fornecidas por juízes que atuem no processo abandonando a imparcialidade que lhes é exigida $^{177}$. Em outras palavras, se o erro policial não puder ser considerado razoável, a exceção não poderá ser invocada e a prova será inadmissível ${ }^{178}$.

O caso Hudson v. Michigan ${ }^{179}$, julgado em 15 de maio de $2006^{180}$ pelo Tribunal Superior dos EUA é emblemático e marca definitivamente uma mudança de entendimento pela Corte Suprema no que tange à questão das regras de exclusão de provas no país.

No referido caso agentes de polícia obtiveram mandado judicial para realizar uma busca e apreensão de drogas e armas de fogo, na residência do Senhor Hudson. Chegando no local, os policiais anunciaram sua presença e, logo após, adentraram a casa, visto que a porta não estava trancada. No interior da residência encontraram grande quantidade de droga e uma arma municiada, tendo sido referidos objetos apreendidos e Hudson preso.

\footnotetext{
176 ÁVILA, Thiago André Pierobom. Provas ilícitas e Proporcionalidade, p. 147.

${ }^{177}$ BLOOM, Robert; BRODIN, Mark. Criminal Procedure: Examples and Explanatios, p. 241.

${ }^{178}$ BLOOM, Robert; BRODIN, Mark. Criminal Procedure: Examples and Explanatios, p. 242.

${ }^{179}$ Disponível em: <http://www.law.cornell.edu/supct/html/04-1360.ZS.html>. Acesso em: 28 maio 2010.

${ }^{180}$ Vale lembrar que o momento histórico vivido pelos Estados Unidos mostrava-se favorável ao recrudescimento penal, com a redução de garantias penais e processuais penais, como ocorreu com a publicação do USA Patriot Act, apenas 45 dias após os ataques terroristas em Nova York e Washington, em 11 de setembro de 2001.
} 
Após tramitar pelas instâncias judiciais inferiores sem sucesso, o réu recorreu à Suprema Corte alegando que a busca realizada em sua casa teria violado a regra do "knockand-announce" inserta, de forma implícita, na Emenda IV à Constituição dos EUA. Segundo sustentou, os policiais deveriam bater na porta antes de entrar de forma açodada em sua casa, pleiteando, em razão disso, a inadmissibilidade dos corpos de delito apreendidos no caso.

A Corte Suprema, entretanto, rechaçou tal argumento, declarando que a exclusão de provas seria o último recurso e não o primeiro impulso a ser adotado no caso ${ }^{181}$.

Ademais, a Suprema Corte afirmou na mesma oportunidade que a responsabilização civil dos oficiais de polícia que afrontem direitos constitucionais no exercício de suas atividades seria uma medida efetiva, parecendo inclinar-se para outras soluções que não a exclusão de $\operatorname{provas}^{182}$.

Desde então, tal decisão tem sido utilizada como precedente por tribunais inferiores do país para embasar a não exclusão de provas obtidas em ofensa às Emendas Constitucionais nos EUA em casos variados, inclusive em situações que se distanciam em muito da não observância da regra do "knock-and-announce" 183 .

Interessante notar ainda que a Suprema Corte poderia ter adotado na decisão do caso Hudson v. Michigan a exceção à regra de exclusão de provas do erro inócuo, por ser aí plenamente aplicável. No entanto a Corte Superior dos Estados Unidos houve por bem introduzir nova exceção no caso concreto, sem construir qualquer tese jurídica nesse sentido, apenas sob a rubrica de que as regras de exclusão não seriam mais necessárias para a polícia norte-americana.

Outro subterfúgio que tem sido utilizado pela Suprema Corte dos Estados Unidos a fim de limitar as regras de exclusão de provas nos casos levados à sua análise é o de restringir ao máximo a legitimidade de quem possa requerer a exclusão de provas. Apenas o indivíduo diretamente atingido pela infração às Emendas Constitucionais poderia requerer a exclusão da prova dos autos.

\footnotetext{
${ }^{181}$ DÍEZ, Carlos Gómez-Jara. Nuevas tendencias en materia de prueba ilícita: El caso Hudson v. Michigan y el caso da la Exclusionary Rule en EE.UU. Revista de Derecho y Proceso Penal, Navarra, n. 20, 2008, p. 34.

${ }^{182}$ DEU, Teresa Armenta. La prueba ilícita (un estudio comparado). Madrid: Marcial Pons, 2009, p. 31.

${ }^{183}$ Conforme, por exemplo, United States v. Southerland e United States v. Hector.
} 
Restringe-se a legitimidade para requerer a exclusão de provas ilícitas dos autos do processo e com isso amplia-se a possibilidade de que no caso concreto sejam valoradas tais provas. Essa limitação tem sido chamada de standing for motion to supress ${ }^{184}$.

Além disso, vale ressaltar que o entendimento atual amplamente dominante na Suprema Corte Norte-Americana é o de que as regras de exclusão de provas apenas são aplicáveis em processos criminais, não podendo ser invocadas em habeas corpus ou em processos cíveis $^{185}$.

Tal tese encontra fundamento no fato de que, modernamente, as exclusionary rules têm sido consideradas como um remédio judicial criado pelos Tribunais que somente deve ser aplicado após ser feita uma análise de "custo-benefício" do caso em questão.

$\mathrm{Ou}$ seja, atualmente tem prevalecido que as provas ilícitas apenas serão excluídas dos autos do processo se, no caso concreto, tal exclusão for considerada realmente necessária. Este entendimento tem ganhado força, se sobrepondo à idéia de que as regras de exclusão se constituiriam elas próprias em mandamentos constitucionais ${ }^{186}$. Assim, essa nova visão acaba por mitigar, em muito, a própria tese das exclusionary rules, desenvolvida inicialmente naquele país.

\subsection{Prova ilícita na Alemanha}

O tema das provas ilícitas é tratado no ordenamento alemão como proibições de provas (die Beweisverbote). Entretanto é preciso pontuar que sob a mesma nomenclatura (provas proibidas) são abarcadas situações bastante distintas.

Não há na Lei Fundamental alemã ou mesmo no Código de Processo Penal do país (StPO) regramento normativo geral proibindo a utilização das provas obtidas por meios ilícitos no processo ${ }^{187}$. Assim a Jurisprudência da Corte Suprema Alemã considera que a prova

\footnotetext{
${ }^{184}$ BLOOM, Robert; BRODIN, Mark. Criminal Procedure: Examples and Explanations, p. 223.

${ }_{185}$ BLOOM, Robert; BRODIN, Mark. Criminal Procedure: Examples and Explanations, p. 235.

${ }^{186}$ BLOOM, Robert; BRODIN, Mark. Criminal Procedure: Examples and Explanations, p. 236 e KAMISAR, Yale; LAFAVE, Wayne; ISRAEL, Jerold. Modern Criminal Procedure: Cases Comments and Questions, p. 129.

${ }^{187}$ ROGALL, Klaus. Questioni fondamentali in tema di divieti probatori. L'indice penale, Padova, ano I, n. 3, set./dez. 1998, p. 1085-1086.
} 
será inadmissível ou não valorada no curso do processo somente quando a lei, expressamente e de forma excepcional o determinar, como ocorre com o artigo 136a do StPO, ou diante de motivos superiores verificados no caso concreto ${ }^{188}$.

De fato, o StPO no artigo $136 \mathrm{a}^{189}$ estabelece métodos de interrogatório proibidos, que se forem utilizados implicarão a exclusão das declarações do interrogado, mesmo que no caso o indivíduo tenha consentido em sua utilização. Trata-se do uso de coação psíquica, maus tratos, exaustão, interferência corporal, utilização de drogas, tortura, meios que propiciem o engano, hipnose, promessas ilegais ou qualquer outro método que atente contra a livre determinação de vontade do declarante ${ }^{190}$.

Modernamente, o Superior Tribunal Federal Alemão tem entendido que caso o interrogado não seja advertido de seus direitos, como acerca do seu direito ao silêncio, ou de se fazer acompanhar por advogado durante sua inquirição, o conteúdo das declarações por ele proferidas não poderá ser valorado pelo juiz ${ }^{191}$. Entretanto, se ficar demonstrado que no caso em apreço o interrogando conhecia seus direitos ou que estava assistido de seu advogado, mas não requereu a exclusão da prova tempestivamente (por exemplo no caso de não ter sido alertado do seu direito de se manter silente), o interrogatório será validado.

188 GUARIGLIA, Fabricio. Concepto, fin y alcance da las prohibiciones de valoración probatoria en el procedimiento penal: Una propuesta de fundamentación, p. 8, nota de rodapé n. 4.

189 " 136 a. StPO

(1) Die Freiheit der Willensentschließung und der Willensbetätigung des Beschuldigten darf nicht beeinträchtigt werden durch Mißhandlung, durch Ermüdung, durch körperlichen Eingriff, durch Verabreichung von Mitteln, durch Quälerei, durch Täuschung oder durch Hypnose. Zwang darf nur angewandt werden, soweit das Strafverfahrensrecht dies zuläßt. Die Drohung mit einer nach seinen Vorschriften unzulässigen Maßnahme und das Versprechen eines gesetzlich nicht vorgesehenen Vorteils sind verboten.

(2) Maßnahmen, die das Erinnerungsvermögen oder die Einsichtsfähigkeit des Beschuldigten beeinträchtigen, sind nicht gestattet.

(3) Das Verbot der Absätze 1 und 2 gilt ohne Rücksicht auf die Einwilligung des Beschuldigten. Aussagen, die unter Verletzung dieses Verbots zustande gekommen sind, dürfen auch dann nicht verwertet werden, wenn der Beschuldigte der Verwertung zustimmt".

${ }^{190}$ Tradução livre feita do texto legal em inglês.

"Section 136a. StPO

Prohibited Methods of Examination.

(1) The accused's freedom to make up his mind and to manifest his will shall not be impaired by ill-treatment, induced fatigue, physical interference, administration of drugs, torment, deception or hypnosis. Coercion may be used only as far as this is permitted by criminal procedure law. Threatening the accused with measures not permitted under its provisions or holding out the prospect of an advantage not envisaged by statute shall be prohibited.

(2) Measures which impair the accused's memory or his ability to understand shall not be permitted.

(3) The prohibition under subsections (1) and (2) shall apply irrespective of the accused's consent. Statements which were obtained in breach of this prohibition shall not be used, even if the accused agrees to their use".

${ }^{191}$ ÁVILA, Thiago André Pierobom. Provas ilícitas e Proporcionalidade, p. 165. 
A despeito da falta de previsão legal, tem se sustentado que a questão da proibição de provas tem fundamento constitucional, justificada especialmente nos princípios inerentes ao Estado de Direito e na ponderação dos interesses envolvidos ${ }^{192}$.

A doutrina tedesca classifica as proibições de prova em: proibições de produção da prova e proibições de valoração da prova ${ }^{193}$. Assim, a proibição de produção de uma prova não acarretará necessariamente a proibição de valoração da mesma ${ }^{194}$. A proibição de valoração da prova (ou de sua utilização) requer disposição legal expressa ou fundamentação teórica consistente nesse sentido, empregando para tanto sobretudo a idéia de ponderação de interesses $^{195}$.

As proibições de produção probatória se subdividem em: proibições de temas probatórios, proibições de meios de prova, proibições de métodos probatórios e proibições probatórias relativas.

As proibições de temas probatórios se referem a determinados fatos que não podem ser objeto de produção de prova, como no caso de um segredo de Estado.

Já as chamadas proibições de meios de prova dizem respeito, na verdade, a elementos ou fontes de prova (conforme o caso) que não podem ser utilizadas no caso concreto, como por exemplo, as declarações por escrito de um médico, por ter dever de sigilo sobre seus pacientes, ou o testemunho de pessoas parentes do investigado, que possam legitimamente se recusar a depor. Para o sistema brasileiro seriam casos de privilégios e não de ilicitude probatória ${ }^{196}$.

As proibições de métodos probatórios, por sua vez, são trazidas pelo artigo 136a do StPO e consistem em verdadeiras provas ilícitas.

Por fim, as proibições probatórias relativas compreendem diligências que necessitam de algum tipo de autorização especial para serem empreendidas, ou exigem que uma dada pessoa as execute, como no caso de uma interceptação telefônica que requer autorização judicial para ser realizada ou, em casos de extrema urgência, autorização de um

\footnotetext{
192 ÁVILA, Thiago André Pierobom. Provas ilícitas e Proporcionalidade, p. 163.

${ }^{193}$ ROXIN, Claus. Derecho procesal penal. Tradução de Gabriela Córdoba; Daniel Pastor. 25. ed. Buenos Aires: Editores del Puerto, 2000, p. 190.

${ }^{194}$ ROXIN, Claus. Derecho procesal penal, p. 192.

${ }^{195}$ DEU, Teresa Armenta. La prueba ilícita (un estudio comparado), p. 49.

${ }^{196}$ SIMONS, Christian Sthefan. A prova ilícita no direito processual penal norte-americano e alemão e as influências no processo penal brasileiro, p. 89-90.
} 
membro do Ministério Público, ratificada por um Magistrado em até três dias ${ }^{197}$. Violações a tais regras no sistema brasileiro implicariam a ilicitude da prova ${ }^{198}$.

As proibições de valoração da prova também se subclassificam em: dependentes e independentes ${ }^{199}$.

As primeiras correspondem às proibições de utilização de prova expressamente previstas em lei. O exemplo recai novamente sobre o artigo 136a do StPO. Ou seja, nesse caso, a lei além de proibir a utilização do método probatório, veda também a valoração dessa prova. Evidenciada a utilização de um método proibido de interrogatório, a prova será excluída.

Já as proibições de valoração probatória independentes referem-se a vedações não expressas no ordenamento, mas decorrentes do sistema jurídico germânico. Seriam proibições à utilização de determinados meios de prova que estariam implícitas na Constituição Alemã, pois violadoras dos direitos da dignidade da pessoa humana e da personalidade do indivíduo ${ }^{200}$.

Entretanto, a despeito dessas classificações doutrinárias expostas é preciso atentar-se para o fato de que a temática das provas proibidas no ordenamento tedesco tem sofrido atenuações com base na aplicação da proporcionalidade ${ }^{201}$, dentre outras inovações pretorianas.

Como afirma Thiago André Pierobom Ávila "na Alemanha, não há uma regra de exclusão genérica de provas obtidas por meios contrários à prescrição legal, havendo soluções pontuais para problemas específicos". ${ }^{202}$

Assim, na tentativa de bem conciliar os interesses estatais de realizar a persecução penal e obter a verdade processualmente atingível, por um lado e o respeito e a proteção dos direitos fundamentais dos envolvidos, por outro, o Tribunal Superior Alemão (BGH) desenvolveu a "teoria dos cursos causais hipotéticos", a "teoria das esferas jurídicas", a

${ }^{197}$ Conforme disposto no $\S 100,1$ e 2 do StPO.

198 ÁVILA, Thiago André Pierobom. Provas ilícitas e Proporcionalidade, p. 164.

${ }^{199}$ ROXIN, Claus. Derecho procesal penal, p. 194.

${ }^{200}$ ROGALL, Klaus. Questioni fondamentali in tema di divieti probatori, p.1073-1074.

${ }^{201}$ Ressalte-se que não é objeto de estudo do presente trabalho a regra da proporcionalidade. Por essa razão serão apenas tecidas breves considerações sobre o tema no item 3.2.1.2 adiante, de modo a possibilitar um melhor entendimento do tratamento dispensado à prova proibida no sistema germânico e demais sistemas (como o brasileiro), nos quais tal mecanismo é utilizado para a solução de conflitos em casos em que ocorrem colisões de direitos fundamentais.

${ }^{202}$ ÁVILA, Thiago André Pierobom. Provas ilícitas e Proporcionalidade, p. 164. 
"teoria dos três degraus" e a "teoria das ponderações de direitos", mais conhecida no Brasil como "princípio da proporcionalidade",203.

A Jurisprudência Alemã tem decidido que, nos casos em que a prova for produzida irregularmente, caso se entenda que uma nova decisão poderia reproduzi-la nas mesmas condições, porém dessa vez sem qualquer irregularidade, a prova ilegal poderá ser admitida. Esse entendimento recebeu o nome de "doutrina dos cursos causais hipotéticos" 204.

É o que ocorre, por exemplo, nos casos em que é determinada a extração de sangue do suspeito. De acordo com o quanto disposto no artigo 81a da StPO tal medida deve ser autorizada judicialmente e executada por um médico. A despeito disso, os Tribunais Alemães têm validado a prova pericial que tenha sido autorizada por policiais e implementada por um enfermeiro, por exemplo ${ }^{205}$, pois se considera que o meio de prova poderia ser reproduzido plenamente, dessa vez conforme a lei.

Ainda com base no mesmo exemplo, argumenta-se que o artigo 81a da StPO visa proteger a saúde e a liberdade do acusado e, nesse sentido, não seria necessária a exclusão da prova irregular dos autos do processo se os bens tutelados não foram infringidos de forma significativa no caso concreto, bastando a punição penal ou disciplinar do agente que desrespeitou a lei, como forma de bem garantir a tutela dos bens protegidos pela norma.

Assim a adoção da chamada "doutrina dos cursos causais hipotéticos" possibilita a admissibilidade e valoração da prova originalmente ilícita e suas derivações pelos tribunais alemães.

De acordo com a "teoria das esferas jurídicas", para se decidir pela valoração ou não da prova obtida com violação de direitos deve-se ter em conta se a lesão afeta de forma considerável os direitos do acusado ${ }^{206}$. Isto é, caso a lesão seja de menor importância ou não se refira ao réu diretamente, a prova será admissível.

A "teoria dos três degraus" afirma que podem ser destacados três níveis distintos da vida privada do indivíduo, representados por círculos concêntricos.

\footnotetext{
${ }^{203}$ DEU, Teresa Armenta. La prueba ilícita (un estudio comparado), p. 51.

204 ÁVILA, Thiago André Pierobom. Provas ilícitas e Proporcionalidade, p. 166.

205 Conforme ÁVILA, Thiago André Pierobom. Provas ilícitas e Proporcionalidade, p. 166 e SIMONS, Christian Sthefan. A prova ilícita no direito processual penal norte-americano e alemão e as influências no processo penal brasileiro, p. 100-101. Embora este último autor afirme nas páginas 90 e 91 que os Tribunais Alemães já decidiram anteriormente em sentido contrário.

${ }^{206}$ ROXIN, Claus. Derecho procesal penal, p. 192-193.
} 
No âmbito mais externo encontra-se a esfera da vida privada stricto sensu, que abrange acontecimentos que o indivíduo não quer tornar públicos. Em um nível intermediário está a esfera da intimidade, da qual participam apenas pessoas escolhidas pelo sujeito e nas quais ele deposita relativo grau de confiança. Já o círculo central e mais diminuto corresponde à esfera do segredo. Nessa esfera estão apenas pessoas muito próximas do indivíduo, nas quais ele confia plenamente para dividir alguns de seus atos ou anseios mais íntimos. Tal esfera deve ser objeto de proteção rigorosa ${ }^{207}$.

Nas palavras de Tiago André Pierobom de Ávila: "no círculo mais interno está o núcleo essencial, inviolável e intangível da vida privada, subtraído de todo juízo de ponderação de interesses. (...) Já numa área intermediária está a área normal da vida privada, expressão e condição do livre desenvolvimento da personalidade; ainda que protegida pela Constituição, não é um direito absoluto, e, portanto, está aberta às colisões decorrentes dos compromissos e vinculações comunitárias. (...) Finalmente, há uma área periférica da vida normal, que apesar de usualmente subtraída do domínio da publicidade, suas lesões são socialmente adequadas e toleradas". 208

Assim, de acordo com tal construção jurisprudencial, seriam admitidas restrições aos círculos mais externos representativos do direito à privacidade do indivíduo (esfera da intimidade e esfera da vida privada stricto sensu), mas não à esfera do segredo ${ }^{209}$.

Com relação ao chamado "princípio da proporcionalidade" voltar-se-á ao tema no item 3.2.1.2 do trabalho.

De modo bastante sucinto, constitui-se em um modelo aplicável para resolver situações em que se verificam colisões de direitos fundamentais, sendo as soluções conferidas segundo a análise feita do caso concreto ${ }^{210}$.

\footnotetext{
${ }^{207}$ COSTA JÚNIOR, Paulo José da. O direito de estar só: Tutela penal da intimidade. 4. ed. São Paulo, Editora Revista dos Tribunais, 2007, p. 29-31.

${ }^{208}$ ÁVILA, Thiago André Pierobom. Provas ilícitas e Proporcionalidade, p. 169.

${ }^{209}$ Conforme SIMONS, Christian Sthefan. A prova ilícita no direito processual penal norte-americano e alemão e as influências no processo penal brasileiro, p. 103-104. Em sentido contrário: ALEXY, Robert. Teoria dos Direitos Fundamentais. Tradução de Virgílio Afonso da Silva. São Paulo: Editora Malheiros, 2008, p. 297-301. A esse respeito o autor em sua concepção subjetiva relativa acerca do conteúdo essencial dos direitos fundamentais entende não ser possível estabelecer a priori um núcleo intangível dos direitos fundamentais, como por exemplo a esfera do segredo em relação ao direito à privacidade dos indivíduos, pois o limite à restringibilidade do direito fundamental apenas poderá ser verificado no caso concreto, após ser aplicado o sopesamento. Afirma ademais o autor que tal limite estará respeitado ainda que no caso concreto após a aplicação da proporcionalidade nada reste do direito fundamental restringido.

${ }^{210}$ A respeito do tema vide ALEXY, Robert. Teoria dos Direitos Fundamentais, p. 116 ss.
} 
De qualquer modo, vale destacar que, a despeito das inovações pretorianas desenvolvidas pela Corte Superior germânica acima aduzidas, violações graves e dolosas a direitos fundamentais praticadas por agentes estatais não são admissíveis no ordenamento alemão.

Com relação às violações praticadas por particulares não é pacífico o entendimento, sendo predominante a posição de que não valeria para eles a regra das

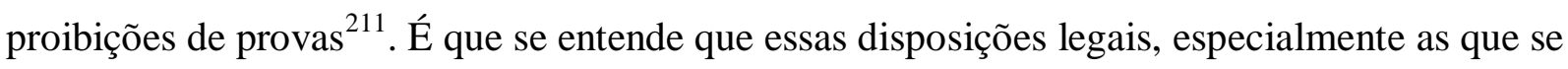
referem a proibições de métodos probatórios, são dirigidas apenas aos órgãos de persecução penal. Portanto, as fontes de provas obtidas por particulares, ainda que com infrações de direitos fundamentais de outros indivíduos seriam admissíveis e valoradas nos autos do processo, desde que não fossem considerados casos de extrema violação de direitos humanos $^{212}$, nem fossem realizados a mando da polícia ${ }^{213}$.

Além das referidas inovações pretorianas, a legislação alemã permite ainda que em situações de emergência, policiais procedam a buscas em domicílios sem mandado judicial, desde que a medida seja autorizada por outra autoridade prevista na lei como o promotor de justiça ou policiais, ficando tal medida sujeita a posterior ratificação judicial em até três dias. São também aceitos no país os testemunhos de ouvir dizer.

Em relação às provas ilícitas por derivação, a tendência prevalente na Alemanha é pela inexistência dos efeitos à distância ${ }^{214}$.

Exemplo disso é a admissão, em certos casos, do chamado "interrogatório por ardil". A polícia vale-se de um terceiro que induz o investigado a confessar-lhe a prática do delito. Então é realizada a oitiva formal desse terceiro, na qual ele relata que o acusado confirmou-lhe ter cometido o crime. Trata-se da admissão de meio de prova derivado da ilicitude inicial.

Admite-se a prova testemunhal, aparentemente produzida de forma regular, havendo nesse caso um verdadeiro testemunho de ouvir dizer, sendo que a testemunha relatará em seu depoimento a confissão do suspeito ou acusado, obtida mediante ardil. ${ }^{215}$

\footnotetext{
${ }^{211}$ ÁVILA, Thiago André Pierobom. Provas ilícitas e Proporcionalidade, p. 171.

${ }^{212}$ ROXIN, Claus. Derecho procesal penal, p. 206.

${ }^{213}$ BELING, Ernst; AMBOS, Kai; GUERRERO, Óscar Julián. Las prohibiciones probatorias, p. 80-81.

${ }^{214}$ Conforme SIMONS, Christian Sthefan. A prova ilícita no direito processual penal norte-americano e alemão $e$ as influências no processo penal brasileiro, p. 104-105 e ÁVILA, Thiago André Pierobom. Provas ilícitas e Proporcionalidade, p. 172.
} 
Aliás, o Tribunal Superior Federal Alemão no julgamento BGH 34, 364 estabeleceu como regra a valoração pelos juízes de provas ilícitas por derivação, por considerar que, de outro modo, acabaria por ser inviabilizada a persecução penal ${ }^{216}$.

Entretanto o mesmo Tribunal afirmou a aplicação dos efeitos extensivos da prova proibida para os casos de violação do segredo epistolar, postal ou de telecomunicações ${ }^{217}$.

Claus Roxin se mostra bastante crítico da não adoção, em regra, da teoria dos frutos da árvore envenenada na Alemanha pois, segundo o autor, de outra forma poderão ser ilididas as proibições probatórias muito facilmente, acabando-se por estimular a adoção de práticas proibidas, com o esvaziamento de sentido das proibições de provas ${ }^{218}$.

Também Klaus Rogall advoga que as proibições de valoração de prova devem produzir, em regra, o efeito à distância ${ }^{219}$.

De qualquer modo, cumpre observar ainda que mesmo nos casos em que são admitidos os efeitos derivados da ilicitude inicial, adotam-se também as exceções às provas ilícitas por derivação advindas do ordenamento estadunidense, chamadas de exceção da fonte independente, da descoberta inevitável e da desconexão de ilicitude, também conhecida como teoria do nexo causal atenuado ${ }^{220}$.

\footnotetext{
215 ÁVILA, Thiago André Pierobom. Provas ilícitas e Proporcionalidade, p. 165/166. Nas palavras do autor: "O fato das autoridades induzirem clandestinamente o imputado a formular declarações auto-incriminadoras deve ser ponderado com a obrigação do Estado de Direito a uma persecução penal efetiva, de forma que o testemunho pode ser introduzido quando se trata do esclarecimento de um fato punível de importante significado, e com o uso de outros métodos de investigação a averiguação dos fatos seria muito menos eficaz ou seria consideravelmente mais complicada".

${ }^{216}$ SIMONS, Christian Sthefan. A prova ilícita no direito processual penal norte-americano e alemão e as influências no processo penal brasileiro, p. 104.

${ }^{217}$ ROXIN, Claus. Derecho procesal penal, p. 205.

${ }^{218}$ ROXIN, Claus. Derecho procesal penal, p. 205-206.

${ }^{219}$ ROGALL, Klaus. Questioni fondamentali in tema di divieti probatori, p.1102.

220 ÁVILA, Thiago André Pierobom. Provas ilícitas e Proporcionalidade, p. 172-173.
} 


\subsection{Prova ilícita em Portugal}

O tratamento dispensado pelo ordenamento português à prova ilícita, lá chamada prova proibida, tem assento constitucional, conforme previsto no artigo $32, \mathrm{n}^{\circ} 8$ da Constituição da República Portuguesa ${ }^{221}$.

Segundo Helena Morão, “a Lei Fundamental portuguesa procede ela própria a uma seleção de direitos fundamentais, cuja violação produz referida nulidade de prova, formada pelos direitos à integridade pessoal, à reserva da vida privada e à inviolabilidade do domicílio, da correspondência e das telecomunicações". ${ }^{222}$

No âmbito infraconstitucional o tema é tratado pelo Código de Processo Penal no artigo $126^{223}$.

Conforme disposto em lei, não serão admissíveis como elemento de prova, não podendo ingressar nos autos do processo os dados e informações que tenham sido obtidos por meio de tortura, coação ou ofensa à integridade física ou moral das pessoas. Caso tais

\footnotetext{
221 “Artigo 32 da Constituição da República Portuguesa
}

Garantias de processo criminal

(...)

8. São nulas todas as provas obtidas mediante tortura, coação, ofensa da integridade física ou moral da pessoa, abusiva intromissão na vida privada, no domicílio, na correspondência ou nas telecomunicações”.

${ }^{222}$ MORÃO, Helena. O efeito à distância das proibições de prova no Direito Processual Penal Português. Revista Portuguesa de Ciência Criminal, Coimbra, ano 16, n. 4, out./dez. 2006, p. 587.

223 “Artigo 126 do Código de Processo Penal Português

Métodos proibidos de prova

1 - São nulas, não podendo ser utilizadas, as provas obtidas mediante tortura, coação ou, em geral, ofensa da integridade física ou moral das pessoas.

2 - São ofensivas da integridade física ou moral das pessoas as provas obtidas, mesmo que com consentimento delas, mediante:

a) Perturbação da liberdade de vontade ou de decisão através de maus tratos, ofensas corporais, administração de meios de qualquer natureza, hipnose ou utilização de meios cruéis ou enganosos;

b) Perturbação, por qualquer meio, da capacidade de memória ou de avaliação;

c) Utilização da força, fora dos casos e dos limites permitidos pela lei;

d) Ameaça com medida legalmente inadmissível e, bem assim, com denegação ou condicionamento da obtenção de benefício legalmente previsto;

e) Promessa de vantagem legalmente inadmissível.

3 - Ressalvados os casos previstos na lei, são igualmente nulas, não podendo ser utilizadas, as provas obtidas mediante intromissão na vida privada, no domicílio, na correspondência ou nas telecomunicações sem o consentimento do respectivo titular.

4 - Se o uso dos métodos de obtenção de provas previstos neste artigo constituir crime, podem aquelas ser utilizadas com o fim exclusivo de proceder contra os agentes do mesmo". 
elementos indevidamente sejam inseridos nos autos não poderão ser valorados pelo juiz ao proferir a sentença, devendo ser desentranhados.

O mesmo dispositivo prevê ainda serem igualmente "nulas", não podendo ser utilizadas, as provas obtidas mediante intromissão na vida privada, no domicílio, na correspondência ou nas telecomunicações sem o consentimento do respectivo titular, ressalvados os casos previstos em lei.

Esses meios de prova proibidos somente poderão ser utilizados com o fim exclusivo de fazer prova contra os agentes estatais que violaram tais direitos fundamentais e desde que referidas condutas constituam crimes.

$\mathrm{O}$ artigo 126, $\mathrm{n}^{\mathrm{o}} 1$ do estatuto processual penal português fala em nulidade da prova proibida. Entretanto não será efetivamente esta a consequiência da utilização da prova ilícita. Nesse ponto é preciso distinguir o sistema de nulidades previsto no CPP português, do caso em tela, no qual de fato estaria configurada a impossibilidade de utilização da prova. Essa diferenciação encontra inclusive respaldo legal.

$\mathrm{O}$ artigo $118, \mathrm{n}^{\mathrm{o}} 3$ do $\mathrm{CPP}^{224}$ prevê que as disposições do Código de Processo Penal português acerca das nulidades não prejudicam as normas que tratam, no mesmo diploma legal, das proibições de prova, sinalizando que o regramento e a conseqüência dos institutos são distintos.

De fato, no campo das nulidades temos um ato que não observou as exigências e formalidades legais e que poderá ser sanado, com a prática das exigências faltantes, ou, quando muito, no caso de nulidade absoluta, sendo refeito todo o ato agora sem o vício anterior. Já na proibição das provas temos a total inadmissibilidade no processo dos elementos obtidos. Não há que se falar aqui em sanar a ilicitude. É que os dados foram colhidos com ofensa aos bens mais caros ao indivíduo, de modo que nem com a sua anuência poder-se-ia afastar a ilicitude da prova, justamente por estarmos lidando com bens indisponíveis (dignidade da pessoa humana, integridade física e psíquica etc.).

\footnotetext{
224 “'Artigo 118 do Código de Processo Penal Português Princípio da legalidade

(...)

3 - As disposições do presente título não prejudicam as normas deste Código relativas a proibições de prova".
} 
Assim, parece adequada a seguinte conclusão: "a proibição de prova sempre estará atrelada à admissibilidade da prova, e esta funcionando de forma antecipada; ao contrário a nulidade sempre estará acompanhada da irregularidade do ato processual". ${ }^{225}$

A prova ilícita por derivação, denominada em Portugal "efeito à distância" ou "efeito remoto" ou ainda "tele-efeito",226, é reconhecida pela doutrina e Jurisprudência lusitanas $^{227}$.

Helena Morão entende ser imprescindível a adoção da proibição das provas ilícitas por derivação pela própria literalidade do artigo 32, nº 8 da Constituição da República Portuguesa, que proclama serem nulas todas as provas obtidas mediante tortura, coação ou ofensa à integridade física ou moral do indivíduo, sem fazer qualquer distinção quanto ao nível do grau imediato ou mediato de sua obtenção. A autora, baseando-se no princípio da máxima efetividade do texto constitucional, argumenta ainda que "a interpretação que mais longe leva a finalidade protetora dos direitos elencados no artigo $32, \mathrm{n}^{\circ} 8$ da Constituição e que melhor maximiza a sua tutela, é, sem dúvida, aquela que não conduz à destrinça entre prova direta e indiretamente obtida através de métodos proibidos". 228

Entretanto, a adoção da teoria da inadmissibilidade das provas derivadas das ilícitas nos autos do processo não impede a admissão de limitações a esse "efeito remoto" da proibição no país. De fato, encontram-se diversas correntes na doutrina processual penal portuguesa a este respeito, destacando-se as seguintes.

Uma primeira corrente perfilha-se na busca de soluções conciliatórias para o caso concreto através da ponderação casuística dos interesses, tendo se em conta especialmente a busca da verdade material ${ }^{229}$ e a punição dos reais culpados, quanto mais na criminalidade grave $\mathrm{e}^{230}$.

\footnotetext{
${ }^{225}$ VALLE FILHO, Oswaldo Trigueiro do (Coord.). Estudos Jurídicos Luso-Brasileiros (UNIPÊ/COIMBRA). João Pessoa: UNIPÊ Editora, 2006, p. 55.

${ }^{226}$ As diferentes denominações conferidas às provas ilícitas por derivação são encontradas no texto de MORÃO, Helena. O efeito à distância das proibições de prova no Direito Processual Penal Português, p. 600-601.

${ }^{227}$ ANDRADE, Manuel da Costa. Sobre as Proibições de Prova em Processo Penal, p. 313-314.

${ }^{228}$ MORÃO, Helena. O efeito à distância das proibições de prova no Direito Processual Penal Português, p.599.

${ }^{229}$ Conforme já abordado no item 1.2 do trabalho tal conceito encontra-se em desuso pela moderna doutrina processual penal.

${ }^{230}$ Conforme GONÇALVES, Manuel Lopes Maia. Código de Processo Penal: Anotado. 11. ed. Coimbra: Almedina, 1999, p. 672 e SANTOS, Manuel Simas; LEAL-HENRIQUES, Manuel. Código de Processo Penal Anotado. Lisboa: Rei dos Livros, 1999. v. 1, p. 672.
} 
Um segundo posicionamento se coloca no sentido de que se deva averiguar relativamente a cada proibição de prova concreta se o seu fim de proteção exige ou não o afastamento processual das provas secundárias obtidas na seqüência da violação inicial ${ }^{231}$.

Para uma terceira corrente, será admissível a prova secundária se, com base em um juízo de causalidade hipotético for possível afirmar que as autoridades de investigação teriam com certeza, ou forte probabilidade, chegado igualmente ao mesmo meio de prova secundário, através de um percurso de indagação lícito e respeitador das proibições de prova. Em outras palavras, trata-se da adoção da descoberta inevitável (inevitable discovery exception), admitida na doutrina norte-americana como limitação à teoria da fruits of the poisonous tree doctrine ${ }^{232}$.

Uma última posição se alinha no sentido de que nos casos de fonte independente (independent source exception), isto é, no caso em que exista ao lado do caminho proibido uma fonte autônoma de onde as provas possam também ter sido retiradas, a prova será admissível. Conforme esse entendimento, entretanto, não será aceita a prova que derivar da ilícita com base na idéia da descoberta inevitável.

Além disso, de acordo com este último posicionamento será também permitida a prova secundária se a mácula do processo puder ser considerada como tendo sido apagada através da atuação livre do argüido ou de um terceiro. Por exemplo, no caso de uma testemunha que presta depoimento invalidado por força da violação de uma proibição de prova e depois, cientificada da inadmissibilidade do depoimento anterior, volta a fazer as mesmas declarações, desta vez de livre vontade. Trata-se da adoção da taint doctrine norteamericana $^{233}$.

Seja como for, certo é não haver nos Tribunais lusitanos uniformidade no que toca às limitações à prova ilícita por derivação. De fato, os julgados parecem passear pelas diversas teorias apresentadas de acordo com o caso concreto posto sub judice.

\footnotetext{
${ }^{231}$ Segundo PIMENTA, José da Costa. Código de Processo Penal Anotado. 2. ed. Lisboa: Rei dos Livros, 1991, p. 378-379.

${ }^{232}$ MENDES, Paulo de Sousa. O processo penal em acção. In: Questões Avulsas de Processo Penal. Lisboa: AAFDL, 2000, p. 101.

${ }^{233}$ MORÃO, Helena. O efeito à distância das proibições de prova no Direito Processual Penal Português, p. 620.
} 
Em relação a um ponto específico no que tange à ilicitude probatória - a figura dos "homens de confiança" - discute-se também a admissibilidade do uso de tal artifício em Portugal.

A questão está em definir se essa medida enquadra-se ou não na vedação à prova determinada pela lei portuguesa, por ser considerada como ofensiva da integridade moral dos indivíduos, constituindo meio enganoso e perturbador da liberdade de vontade e decisão da pessoa.

A doutrina lusitana abrange sob a denominação "homens de confiança" as figuras do agente infiltrado, do agente provocador e do agente encoberto ${ }^{234}$.

O agente infiltrado é definido como um funcionário da investigação criminal ou um terceiro (particular) que atua sob o controle da polícia, com ocultação de sua qualidade e identidade, com o fim de obter provas. Age ganhando a confiança pessoal do investigado. Não determina nem induz à prática de crimes. Possui função meramente informativa; visa colher provas e informações sobre crimes.

Já o agente provocador atua de modo a determinar a prática de crimes pelo suspeito. É ele quem, no caso concreto, induz o investigado a praticar o delito.

Com relação ao agente encoberto há que se fazer um esclarecimento prévio.

Tal denominação é utilizada pela Lei no 101/2001 (que fala de ações encobertas) indicando o gênero nas quais estariam abrangidas as demais figuras vistas. Entretanto, parte da doutrina vale-se da mesma nomenclatura "agente encoberto", para referirse ao policial "à paisana". Ou seja, sob esta ótica, o agente encoberto corresponderia a uma conduta passiva do policial não trajado oficialmente, que presencia crimes, por suspeitar que os mesmos ocorreriam em dado local e ocasião ${ }^{235}$.

A Jurisprudência portuguesa tem aceitado a utilização dos agentes infiltrados e agentes encobertos no âmbito da investigação e processo criminal, nos limites da Lei $n^{\circ}$ 101/2001, que trata do tema. Entretanto tem entendido como proibida a prova obtida a partir

\footnotetext{
${ }^{234}$ Conforme JUSTO, Ana Rita de Melo. Proibição da prova em processo penal: o agente provocador; acórdão do Supremo Tribunal de Justiça de 30 de outubro de 2002. Revista Portuguesa de Ciência Criminal, Coimbra, ano 16, n. 3, jul./set. 2006, p. 503-505 e VALENTE, Manuel Monteiro Guedes. Processo Penal. Coimbra: Almedina, 2004. tomo I, p. 444-462.

${ }^{235}$ VALENTE, Manuel Monteiro Guedes. Processo Penal. tomo I, p. 459.
} 
do agente provocador, por configurar um meio enganoso e perturbador da liberdade de vontade e decisão do indivíduo, nos termos do artigo 126, n 2, alínea "a", do CPP 236 .

\subsection{Prova ilícita na Espanha}

A atual Constituição espanhola não possui dispositivo expresso a determinar a necessidade de adoção de uma regra de exclusão para as provas obtidas por meios ilícitos. De fato, o artigo 24. 2 da Lei Maior da Espanha ${ }^{237}$, tratando do direito à prova, estabelece apenas ao acusado a garantia de utilizar os meios de prova pertinentes a sua defesa.

Para suprir tal lacuna foi editada em 1984 a Lei Orgânica do Poder Judiciário, que em seu o artigo $11.1^{238}$ declara que as provas obtidas direta ou indiretamente com violação de direitos e liberdades fundamentais, não surtirão efeitos.

Vale notar que, a despeito de se tratar de uma disposição legal, o Tribunal Constitucional espanhol tem sustentado que "a regra de exclusão do art. 11.1 da LOPJ possui como fundamento constitucional o direito a um processo com todas as garantias". 239

A expressão "não surtirão efeitos", utilizada pela lei espanhola no artigo 11.1 da LOPJ, tem sido interpretada como uma vedação à admissão das provas ilícitas nos autos do processo, sendo que, caso dele constem erroneamente, a expressão deverá ser traduzida na proibição de valoração desses elementos pelo juiz ${ }^{240}$.

\footnotetext{
${ }^{236}$ VALENTE, Manuel Monteiro Guedes. Processo Penal. tomo I, p. 448-450.

237 “Art. 24 Constitución Española

(...)

2. Asimismo, todos tienen derecho al Juez ordinario predeterminado por la ley, a la defensa y a la asistencia al letrado, a ser informados de la acusación formulada contra ellos, a un proceso público sin dilaciones indebidas y con todas las garantías, a utilizar los medios de prueba pertinentes para su defensa, a no declarar contra sí mismos, a no confesarse culpables y a la presunción de inocencia. La ley regulará los casos en que, por razón de parentesco o de secreto profesional, no se estará obligado a declarar sobre hechos presuntamente delictivos".

238 “Art. 11 LOPJ (Ley Orgánica del Poder Judicial)

1. (...) No surtirán efecto las pruebas obtenidas, directa o indirectamente, violentando los derechos o libertades fundamentales".

${ }^{239}$ ÁVILA, Thiago André Pierobom. Provas ilícitas e Proporcionalidade, p. 178.

${ }^{240}$ Conforme CASTRILLO, Eduardo de Urbano; MORATO, Miguel Angel Torres. La Prueba Ilícita Penal: Estudio Jurisprudencial. 2. ed. Pamplona: Editora Aranzadi, 2000, p. 39-43 e MELLADO, José María Asencio. Prueba Prohibida y Prueba Preconstituida en el Proceso Penal. Lince: Instituto Peruano de Criminologia y Ciencias Penales, 2008, p. 122-123.
} 
A expressão “indiretamente", empregada pelo mesmo dispositivo legal, é interpretada como uma referência à vedação à prova ilícita por derivação. Assim, a vedação à ilicitude derivada, que na doutrina espanhola é chamada de efeito reflexo ${ }^{241}$, tem sede legal no ordenamento espanhol ${ }^{242}$.

Analisando a redação do artigo 11.1 da LOPJ, é de se perceber que apenas serão consideradas sem efeito as provas obtidas, direta ou indiretamente, com violação de direitos e liberdades fundamentais. Isto significa que "a lesão às disposições meramente legais não deve ativar a garantia constitucional da inadmissibilidade, mas apenas considerar as regras infraconstitucionais relativas às nulidades (art. $238.3 \mathrm{LOPJ}^{243}$ ). Esse entendimento tem sido aplicado pela Sala Segunda do Tribunal Superior, que distingue os planos da licitude constitucional, que ativa a garantia do art. 11.1 LOPJ e, da legalidade ordinária, que ativa as regras de nulidade previstas no art. 238 et seq. da LOPJ, não se admitindo nesse último nível a existência de efeito reflexo da prova". ${ }^{244}$

Com vistas a flexibilizar os efeitos da ilicitude por derivação e uniformizar o entendimento acerca da matéria, o Tribunal Constitucional espanhol, na decisão STC 81/1998, desenvolveu a chamada teoria da conexão de antijuridicidade ${ }^{245}$.

Segundo tal teoria, para que se possa concluir pela proibição de admissão e valoração da prova reflexa é necessário que exista uma vinculação destas provas àquelas obtidas com violação direta de algum direito fundamental ${ }^{246}$. Em outras palavras, deve haver um nexo que ligue umas às outras, de modo que seja possível afirmar que a ilicitude inicial se

\footnotetext{
${ }^{241}$ MELLADO, José María Asencio. Prueba Prohibida y Prueba Preconstituida en el Proceso Penal, p. 126.

${ }^{242}$ SERRANO, Nicolas Gonzalez-Cuellar. Proporcionalidad y derechos fundamentales en el processo penal. Madrid: Colex, 1990, p. 334.

243 “Art. 238 LOPJ

Los actos judiciales serán nulos de pleno derecho en los casos siguientes:

(...)

3. Cuando se prescinda total y absolutamente de las normas esenciales de procedimiento establecidas por la ley o con infracción de los principios de audiencia, asistencia y defensa, siempre que efectivamente se haya producido indefensión".

${ }^{244}$ ÁVILA, Thiago André Pierobom. Provas ilícitas e Proporcionalidade, p. 177. Em sentido contrário SERRANO, Nicolas Gonzalez-Cuellar. Proporcionalidad y derechos fundamentales en el processo penal, p. 340. 245 ÁVILA, Thiago André Pierobom. Provas ilícitas e Proporcionalidade, p. 181.

${ }^{246}$ Conforme constou da decisão STC 81/98 de 02 de abril de 1998: "para concluir que la prohibición de valoración se extiende también a ellas (las pruebas reflejas), habrá de precisarse que se hallan vinculadas a las que vulneraron el derecho fundamental sustantivo de modo directo, esto es, habrá que establecer un nexo entre unas y otras que permita afirmar que la ilegitimidad constitucional de las primeras se extiende también a las segundas (conexión de antijuridicidad). En la presencia o ausencia de esa conexión reside, pues, la 'ratio' de la interdicción de valoración de las pruebas obtenidas a partir del conocimiento derivado de otras que vulneran el derecho al secreto de las comunicaciones".
} 
estende também às provas derivadas ${ }^{247}$. Assim não verificado o referido liame aplicar-se-á, $a$ contrario sensu, a desconexão de antijuridicidade, mitigando os efeitos reflexos da prova e passando a prova secundária a ser admitida no caso.

O caso paradigma que serviu como pano de fundo para o desenvolvimento de tal mitigação aos efeitos reflexos da prova foi o seguinte: dado indivíduo estava sendo investigado pela suposta prática do crime de tráfico de drogas ${ }^{248}$. Em razão disso, foi requerida e concedida ordem para que se realizasse a interceptação telefônica do suspeito. A partir da escuta e gravação de seus diálogos telefônicos, a polícia espanhola teve ciência de que em certo dia e hora o investigado receberia uma quantidade de droga. Assim, procedeu-se a sua prisão em flagrante, sendo encontrada com ele a referida droga. Ocorre que, tanto na representação policial que requereu a realização da interceptação telefônica, quanto na decisão judicial autorizando tal escuta, não foi observado o requisito constitucional de explicitação do objeto da investigação. Com base nisso, a defesa do preso interpôs recurso requerendo a sua liberdade, argumentando que a prova originária era ilícita (interceptação telefônica) e logo as provas subseqüentes também estariam contaminadas (depoimentos dos policiais que efetuaram a prisão e o próprio corpo de delito: a droga).

O Ministério Público Espanhol (Fiscalia) proferiu parecer favorável à tese da ocorrência dos efeitos reflexos, sustentada pela defesa.

Entretanto, o Tribunal Superior afirmando ser a punição de delitos graves também um valor constitucional entendeu que, no caso concreto, as provas derivadas não eram em si ilícitas, pois o efeito reflexo referido pela defesa apenas ocorreria quando presente uma conexão de antijuridicidade entre a prova inicial e a posterior, que não se verificava no caso em tela, surgindo aí a teoria ${ }^{249}$.

${ }^{247}$ SEGADO, Carmelo Jiménez. La prueba ilícita y las reglas de desconexión de sus efectos. La Ley Penal: Revista de Derecho Penal, Procesal y Penitenciario, Madrid, ano VI, n. 58, mar. 2009, p. 23.

248 Disponível em: <http://www.boe.es/aeboe/consultas/bases datos/doc.php?coleccion=tc\&id=SENTENCIA1998-0081>. Acesso em: 24 jun. 2010 (sítio do Boletín Oficial del Estado de España).

${ }^{249}$ Conforme constou da decisão STC 81/1998: "el Tribunal Supremo entiende que dadas las circunstancias del caso y, especialmente, la observación y seguimiento de que el recurrente era objeto, las sospechas que recaían sobre él y la irrelevancia de los datos obtenidos a través de la intervención telefónica, el conocimiento derivado de la injerencia en el derecho fundamental contraria a la Constitución no fue indispensable ni determinante por sí sólo de la ocupación de la droga o, lo que es lo mismo, que esa ocupación se hubiera obtenido, también, razonablemente, sin la vulneración del derecho. Esa afirmación que, desde la perspectiva jurídica que ahora estamos considerando, rompe, según la apreciación del Tribunal Supremo, el nexo entre la prueba originaria y la derivada, no es, en sí misma un hecho, sino un juicio de experiencia acerca del grado de conexión que determina la pertinencia o impertinencia de la prueba cuestionada. Por consiguiente, no se halla exento de nuestro control; 
Segundo o Tribunal Constitucional espanhol para a configuração da conexão de antijuridicidade entre as provas e o conseqüente efeito reflexo da prova ilícita, são necessários dois requisitos, um interno e outro externo.

No plano interno, é preciso que a prova subseqüente seja de fato derivada da prova ilícita inicial, sendo a ilicitude a ela transferida. Verifica-se aqui a gravidade da lesão aos direitos fundamentais praticada na obtenção da prova ilícita original, de forma a determinar se essa lesão é capaz de alcançar as provas subseqüentes ou não.

Já do ponto de vista externo, requer-se que a necessidade de tutela do direito fundamental ofendido exija a ineficácia probatória do material derivado. Isto é, na análise do caso concreto, para que se confira efetividade ao direito transgredido deve ser imprescindível a taxação de ilicitude da prova reflexa ${ }^{250}$.

Assim nos casos em que inexista nexo de causalidade entre a prova ilícita e a prova secundária, ou em não sendo a lesão praticada aos direitos fundamentais para a obtenção da prova ilícita original de tamanha relevância que possa alcançar as demais, ou ainda não estando presentes motivações extraprocessuais a determinar o efeito reflexo da prova, não estará configurada a conexão de antijuridicidade, admitindo-se portanto a adoção da prova secundária no processo.

Entretanto tal teoria não é aceita de forma unânime na Espanha.

Carmelo Jiménez Segado critica a chamada conexão de antijuridicidade por entender que essa criação pretoriana afronta ao quanto estabelecido no artigo 11.1 da LOPJ $^{251}$. É que a literalidade do artigo proclama não terem efeito as provas obtidas com violação de direitos fundamentais, ainda que de forma indireta. Conforme argumenta, se tal norma que se diz possuir fundamento constitucional, não prevê qualquer exceção ou condição para que se verifique a inadmissibilidade das provas derivadas, não estariam os Tribunais autorizados a modificar o diploma legal, mas tão somente a interpretá-lo.

Ainda segundo o mesmo autor, a justificação material da teoria da conexão de antijuridicidade está na necessidade de se evitar a impunidade nos casos em que pareceria um

pero, dado que, en principio, corresponde a los Jueces y Tribunales ordinarios, el examen de este Tribunal ha de ceñirse a la comprobación de la razonabilidad del mismo y que, en el caso presente no puede estimarse que sea irrazonable o arbitrario, hemos de concluir que, desde el punto de vista antes expuesto, la valoración de la prueba refleja practicada en este caso no vulnera el derecho a un proceso con todas las garantías".

${ }^{250}$ SEGADO, Carmelo Jiménez. La prueba ilícita y las reglas de desconexión de sus efectos, p. 26.

${ }^{251}$ SEGADO, Carmelo Jiménez. La prueba ilícita y las reglas de desconexión de sus efectos, p. 25. 
disparate a ausência de condenação do indivíduo, apenas por terem sido infringidas certas formalidades legais no momento da obtenção da prova. Referida teoria buscaria, na verdade, evitar que a sociedade ficasse alarmada com a atuação dos Tribunais espanhóis no julgamento de casos específicos. Porém, de acordo com Carmelo Jiménez Segado, o que deveria causar clamor público à sociedade seria exatamente a obtenção de provas incriminatórias com vulneração de direitos ${ }^{252}$.

Além da teoria da conexão de antijuridicidade, os Tribunais espanhóis têm adotado em suas decisões mitigações à regra da ilicitude probatória desenvolvidas pela Corte estadunidense $^{253}$, como a teoria da boa-fé policial, bem como atenuações aos efeitos reflexos da prova, como a teoria da fonte independente, da descoberta inevitável e do vício diluído ${ }^{254}$.

\subsection{Prova ilícita na Itália}

O regramento das vedações probatórias no ordenamento italiano vem previsto nos artigos 188 e 191.1 do Código de Processo Penal ${ }^{255}$.

De acordo com o quanto disposto no artigo 188 do CPP não poderão ser utilizados, nem mesmo com o consentimento da pessoa interessada, métodos ou técnicas suficientes para influir sobre a liberdade de autodeterminação do indivíduo inquirido, nem tampouco subterfúgios hábeis a alterar a capacidade de memória e valoração dos fatos objeto de indagação.

O artigo 191.1 do estatuto processual penal italiano prevê por sua vez que, a prova adquirida em violação a proibição estabelecida pela lei não poderá ser utilizada.

\footnotetext{
${ }^{252}$ SEGADO, Carmelo Jiménez. La prueba ilícita y las reglas de desconexión de sus efectos, p. 24-25.

${ }^{253}$ ÁVILA, Thiago André Pierobom. Provas ilícitas e Proporcionalidade, p. 188-189.

${ }^{254}$ SEGADO, Carmelo Jiménez. La prueba ilícita y las reglas de desconexión de sus efectos, p. 26-28.

255 “Art. 188. Codice di Procedura Penale

Libertà morale della persona nell'assunzione della prova.

1. Non possono essere utilizzati, neppure con il consenso della persona interessata, metodi o tecniche idonei a influire sulla libertà di autodeterminazione $\mathrm{o}$ ad alterare la capacità di ricordare e di valutare $\mathrm{i}$ fatti .

Art. 191 Codice di Procedura Penale

Prove Illegitimamente Acquisite.

1. Le prove acquisite in violazzione dei divieti stabiliti dalla legge non possono essere utilizzate;

2. L'inutilizzabilità è rilevabili anche di ufficio in ogni stato e grado del procedimento".
} 
Ademais, o artigo 192.2 estabelece que essa inutilizabilidade da prova poderá ser declarada de ofício pelo julgador a qualquer tempo.

Paolo Tonini explica que "o termo inutilizabilidade descreve dois aspectos do mesmo fenômeno. Por um lado, indica o 'vício' que pode conter um ato ou um documento; por outro lado, ilustra o 'regime jurídico', ao qual o ato viciado é submetido, ou seja, a não possibilidade de ser utilizado como fundamento de uma decisão do juiz." ${ }^{256}$ A inutilizzabilità atinge, não o ato em si, mas o seu valor probatório, de modo que o ato pode ser válido do ponto de vista formal (eis que não eivado de nulidade), entretanto em seu aspecto substancial a inutilizabilidade o impede de servir como fundamento para a decisão judicial.

Assim, conforme determinação do Código de Processo Penal italiano as provas obtidas em infração ao quanto estabelecido pela lei não serão admissíveis nos autos do processo e, caso dele constem, não poderão ser valoradas pelo juiz.

Referidas previsões do Código se coadunam com o quanto fixado pela Constituição do país, que já reconhecia solenemente os direitos de liberdade do indivíduo ${ }^{257}$.

Entretanto, a dificuldade maior está em se definir se o artigo 191.1 do CPP trata apenas de provas ilegítimas ou também das provas ilícitas.

Como já mencionado no trabalho, coube ao autor italiano Pietro Nuvolone estabelecer inicialmente a diferenciação entre provas ilegais, provas ilícitas e provas ilegítimas. Conforme tal entendimento, provas ilegais seriam as obtidas em violação à lei, de um modo geral, ou aos princípios gerais do ordenamento, sendo as provas ilegítimas aquelas que ofendessem normas processuais e ilícitas as que fossem obtidas com transgressão de direitos materiais dos indivíduos. Como já salientado anteriormente, essa diferenciação possui inúmeras aplicações práticas.

Massimo Nobili ${ }^{258}$ entende que a previsão legal do artigo 191.1 do CPP se aplica às provas consideradas ilegítimas, mas também as provas ilícitas, pois o dispositivo fala apenas em "provas adquiridas com violação dos deveres estabelecidos pela lei”, não

\footnotetext{
${ }^{256}$ TONINI, Paolo. A prova no processo penal italiano. Tradução de Alexandra Martins Daniela Mróz. São Paulo: Editora Revista dos Tribunais, 2002, p. 76.

${ }^{257}$ AVOLIO, Luiz Francisco Torquato. Provas ilícitas: Interceptações telefônicas, ambientais e gravações clandestinas, p. 45-49.

${ }^{258}$ NOBILI, Massimo. Commento art. 191. In: CHIAVARIO, Mario (Org.). Commento al nuovo Codice di Procedura Penale. Torino: Utet, 1990. v. 2, p. 409-414.
} 
especificando se a lei trata de direitos processuais ou materiais. Assim, para o autor seriam eivados com o vício da inutilizabilidade tanto as provas ilícitas quanto as ilegítimas.

Paolo Tonini, por sua vez, sustenta que o artigo 191 do Código de Processo Penal trata apenas das provas ilegítimas. Segundo o autor "se a proibição tivesse como objeto a violação de uma lei penal substancial, teria sido utilizada a expressão 'prova ilicitamente adquirida'. Em contrapartida, o nomen iuris do art. 191 refere-se às provas ilegitimamente adquiridas". 259

A Corte italiana diferencia o sistema de nulidade da inutilizzabilità. "A nulidade relaciona-se sempre e apenas à inobservância de alguma formalidade na produção da prova, vício que não põe o procedimento formativo ou aquisitivo completamente fora do parâmetro normativo de referência, mas que não respeita algum de seus pressupostos; ao contrário, a inutilidade (ou inutilizabilidade) pressupõe a presença de uma prova vedada pela sua intrínseca ilegitimidade objetiva". ${ }^{260}$

Assim, ainda que se considere que serão inutilizáveis com fulcro no artigo 191 do CPP apenas as provas ilegítimas, em havendo tão somente violações de mera forma, a prova não será considerada inutilizável.

Segundo afirma Thiago André Pierobom de Ávila, modernamente, a Corte Suprema italiana tem reduzido a aplicação do quanto disposto no artigo 191 do Código de Processo Penal para limitá-lo às situações em que ocorra uma violação direta e expressa de uma proibição determinada.

Conforme o autor, a despeito de serem excluídas as provas obtidas sob tortura ou outros métodos que influenciem a capacidade de avaliação dos fatos pelo indivíduo - por expressa determinação do quanto disposto no artigo 188 do Código de Processo Penal -, a Corte italiana tem afastado a inutilizzabilità nos casos em que é feita a apreensão do próprio corpo de delito, ou de outras fontes de provas consideradas relevantes para o crime, sob a alegação de que nessas situações a polícia estaria apenas cumprindo a determinação do artigo 253 do $\mathrm{CPP}^{261}$. Essa atuação se justificaria tendo em vista que os policiais que praticassem as

\footnotetext{
${ }^{259}$ Conforme TONINI, Paolo. A prova no processo penal italiano, p. 77. No mesmo sentido: FELICIONI, Paola. Le ispezioni e le perquisizioni, p. 461-463.

${ }^{260}$ ÁVILA, Thiago André Pierobom. Provas ilícitas e Proporcionalidade, p. 195-196.

261 "Art. 253 Codice di Procedura Penale

Oggetto e formalità del sequestro.
} 
referidas ilegalidades estariam sujeitos às penalidades previstas no artigo 609 do mesmo Código $^{262}$. Assim, esse entendimento de que o corpo de delito e algumas outras provas devem ser apreendidas de qualquer forma, independente de como se deu sua descoberta, termina por restringir de forma relevante as disposições do referido artigo 191 do Código de Processo Penal italiano ${ }^{263}$.

Em verdade, o que se tem verificado nos julgados italianos é que, nos casos em que não existe regra expressa no ordenamento a vedar a utilização da prova, como ocorre com a proibição da utilização de métodos que afetem a liberdade de autodeterminação do indivíduo, com o artigo 188 do CPP (por exemplo, com o uso do soro da verdade), as demais provas, ainda que obtidas com alguma transgressão ao ordenamento, acabam sendo admitidas, desde que não ocorram violações grosseiras de direitos fundamentais. Ademais, argumenta-se que, em caso de abuso por parte dos policiais, estes responderão criminalmente por isso.

Ressalte-se não haver no ordenamento italiano tratamento específico para a questão da ilicitude por derivação, sendo também naquele país a questão tratada pela doutrina sem o cuidado necessário.

Entretanto, o entendimento prevalente é no mesmo sentido das vedações probatórias originais. Ou seja, inexistindo regra expressa a determinar a inutilizabilidade da prova será esta admitida nos autos do processo e valorada pelo juiz.

De fato, predomina o entendimento de que não poderá ser admitida uma proibição probatória implícita no ordenamento jurídico italiano ${ }^{264}$. É que a regra vigente naquele sistema processual penal é a da utilizabilidade da prova, não sendo esta admitida apenas em função de determinação expressa nesse sentido.

1. L'autorità giudiziaria dispone con decreto motivato il sequestro del corpo del reato e delle cose pertinenti al reato necessarie per l'accertamento dei fatti.

2. Sono corpo del reato le cose sulle quali o mediante le quali il reato è stato commesso nonchè le cose che ne costituiscono il prodotto, il profitto o il prezzo.

3. Al sequestro procede personalmente l'autorità giudiziaria ovvero un ufficiale di polizia giudiziaria delegato con lo stesso decreto.

4. Copia del decreto di sequestro è consegnata all'interessato, se presente".

262 "Art. 609 Codice Penale

Perquisizione e ispezione personali arbitrarie.

Il pubblico ufficiale, che, abusando dei poteri inerenti alle sue funzioni, esegue una perquisizione o un'ispezione personale, è punito con la reclusione fino ad un anno".

263 ÁVILA, Thiago André Pierobom. Provas ilícitas e Proporcionalidade, p. 195.

${ }^{264}$ TONINI, Paolo. A prova no processo penal italiano, p. 80. 
Assim, diante da inexistência de regra a vedar as provas ilícitas por derivação estas, em regra seriam admissíveis ${ }^{265}$.

Um exemplo aproximado pode ser a utilização de declarações autoincriminatórias feitas por um depoente não advertido pela Polícia de que tais informações poderiam ser utilizadas contra si.

Nesse caso, em face da ausência de ciência prévia, as informações obtidas não poderão ser utilizadas contra o depoente, por expressa vedação contida no artigo 63.1 do Código de Processo Penal ${ }^{266}$. Entretanto, o conteúdo das mesmas declarações poderá ser empregado em outras investigações. Ou seja, a prova obtida mediante violação legal não será admitida apenas nos estritos termos da disposição normativa. Contudo, outras investigações derivadas dessa prova inicial serão admitidas, servindo a prova ilegal como notitia criminis legal $^{267}$.

De qualquer forma, certo é que violações copiosas de direitos fundamentais não serão aceitas, devendo se dar nesses casos a inutilização das provas derivadas.

\subsection{Prova ilícita na Inglaterra}

Na Inglaterra, país integrante da Commom Law, a prova proibida é chamada de illegaly obtained evidence.

Como é sabido, em tal país inexiste uma constituição escrita, sendo os casos levados à Corte resolvidos, prioritariamente, com base nos precedentes judiciais.

\footnotetext{
${ }^{265}$ Em sentido contrário, sustentando a adoção da teoria dos frutos da árvore venenosa no ordenamento italiano vide GRINOVER, Ada Pellegrini. Liberdades Públicas e Processo Penal: as interceptações telefônicas, p. 142.

${ }^{266}$ Art. 63. do CPP italiano - Dichiarazioni indizianti.

1. Se davanti all'autorità giudiziaria $\mathrm{o}$ alla polizia giudiziaria una persona non imputata ovvero una persona non sottoposta alle indagini rende dichiarazioni dalle quali emergono indizi di reità a suo carico, l'autorità procedente ne interrompe l'esame, avvertendola che a seguito di tali dichiarazioni potranno essere svolte indagini nei suoi confronti e la invita a nominare un difensore. Le precedenti dichiarazioni non possono essere utilizzate contro la persona che le ha rese.

2. Se la persona doveva essere sentita sin dall'inizio in qualità di imputato o di persona sottoposta alle indagini, le sue dichiarazioni non possono essere utilizzate.

${ }^{267}$ ÁVILA, Thiago André Pierobom. Provas ilícitas e Proporcionalidade, p. 196.
} 
Tradicionalmente, "a finalidade básica do processo inglês é a descoberta da verdade material, e a ilicitude ou ilegalidade cometida na obtenção da prova não altera a verdade representada por esta prova. A polícia pode utilizar-se dos meios para esclarecer o fato e a autoria, no que se reconhece uma ampliação dos poderes discricionários do juiz, competindo a este a valoração de admissibilidade ou não, de uma prova". ${ }^{268}$

De fato, inexiste em tal sistema uma prova que, em abstrato e a priori, possa ser considerada como vedada nos autos do processo. É que sempre vigorou no direito inglês "a regra geral de que os meios de prova devem ser admitidos, independentemente de sua origem". 269

Conforme salienta Ada Pellegrini Grinover no sistema inglês "a ilegalidade cometida é considerada secundária para o processo, porque a admissibilidade da prova é tradicionalmente resolvida à luz de sua relevância". ${ }^{270}$ Entende-se que a exclusão da prova poderá trazer mais injustiça para o julgamento do caso do que sua admissão, prevalecendo esta, portanto, como regra.

Assim, a prova será admissível sempre que puder servir à comprovação de alegações feitas no caso sub judice, deixando-se para o magistrado decidir se, no caso concreto, princípios extraprocessuais de public policy determinam sua exclusão ou não ${ }^{271}$. É dever do julgador decidir acerca da admissibilidade da prova ou não no caso em análise $\mathrm{e}^{272}$.

Portanto, no direito inglês o juiz apenas poderia excluir uma confissão de um acusado, por exemplo, se ficasse provado que esta havia sido obtida de forma involuntária, sendo tal ocorrência de difícil comprovação ${ }^{273}$.

Ocorre que, a despeito disso, a partir da década de 80 a regulamentação da atuação dos agentes estatais durante as investigações penais passou a ser disciplinada de forma mais rigorosa na Inglaterra, com vistas a minimizar o cometimento de erros, maximizar a

\footnotetext{
${ }^{268}$ CASTRO, Raimundo Amorim de. Provas Ilícitas e o Sigilo das Comunicações Telefônicas, p. 96.

269 ÁVILA, Thiago André Pierobom. Provas ilícitas e Proporcionalidade, p. 190.

${ }^{270}$ GRINOVER, Ada Pellegrini. Liberdades Públicas e Processo Penal: as interceptações telefônicas, p. 116.

${ }^{271}$ GRINOVER, Ada Pellegrini. Liberdades Públicas e Processo Penal: as interceptações telefônicas, p. 117118.

${ }^{272}$ UGLOW, Steve. Issues in Evidence in English Criminal Law. Studi Senesi, Siena, v. 112, n. 1, 2000, p. 171.

${ }^{273}$ UGLOW, Steve, Issues in Evidence in English Criminal Law, p. 172.
} 
busca da verdade e garantir direitos aos suspeitos e acusados ${ }^{274}$. Esse novo ideário produziu significativas mudanças na questão das vedações probatórias no sistema inglês ${ }^{275}$.

Nesse contexto foi editado o Police and Criminal Evidence Act de 1984.

O PACE, como ficou conhecido, instituiu no país um Código de Práticas regulamentadoras da detenção, da forma de tratamento dos presos e do interrogatório realizado por policiais, dentre outras determinações ${ }^{276}$.

O instrumento apregoa que o preso deverá ser cientificado por escrito acerca do motivo de sua prisão e de seus direitos, podendo fazer uma ligação telefônica a fim de avisar alguém de sua situação. Ademais determina que o preso deverá ser informado acerca do seu direito de se consultar com um advogado independente, de forma gratuita e em sessão reservada $^{277}$. Poderá o preso ainda ter acesso às regras dispostas no PACE.

O preso deverá ser cientificado do seu direito ao silêncio, sendo também informado de que caso decida falar suas declarações poderão ser usadas contra ele e que, em determinadas situações - contraditoriamente e em ofensa ao quanto estabelecido na Convenção Européia de Direitos Humanos, que garante o direito à presunção de inocência -, seu silêncio poderá prejudicá-lo ${ }^{278}$.

Aduz também o documento que os fundamentos para a prisão deverão ser periodicamente revistos, devendo ser dignas as condições de detenção do preso ${ }^{279}$.

Além disso, em seqüência a todas essas alterações a gravação dos interrogatórios policiais passou a ser obrigatória, como forma de garantir a lisura da atuação dos agentes inquiridores ${ }^{280}$.

Assim, atualmente, por expressa previsão normativa tem-se que a confissão obtida a partir de coação do interrogando, incluindo o uso de violência, tortura, tratamento

\footnotetext{
${ }^{274}$ ASHWORTH, Andrew. The Criminal Process: An Evaluative Study, 2nd ed. New York: Oxford University Press, 1998, p. 93.

${ }^{275}$ GRINOVER, Ada Pellegrini. Liberdades Públicas e Processo Penal: as interceptações telefônicas, p. 119.

${ }^{276}$ UGLOW, Steve, Issues in Evidence in English Criminal Law, p. 173.

${ }^{277}$ ASHWORTH, Andrew. The Criminal Process: An Evaluative Study, p. 71.

${ }^{278}$ Conforme DELMAS-MARTY, Mireille. Procesos Penales de Europa (Alemania, Inglaterra y País de Gales, Bélgica, Francia, Italia). Zaragoza: EDIJUS, 2000, p. 182. A respeito do direito ao silêncio no sistema inglês e sua valoração vide: ASHWORTH, Andrew. The Criminal Process: An Evaluative Study, p. 96 ss.

${ }^{279}$ UGLOW, Steve. Issues in Evidence in English Criminal Law, p. 173.

${ }^{280}$ Conforme UGLOW, Steve. Issues in Evidence in English Criminal Law, p. 174 e ASHWORTH, Andrew. The Criminal Process: An Evaluative Study, p. 94.
} 
desumano ou degradante, ou em ofensa ao quanto estabelecido na Seção 76 do PACE ${ }^{281}$ não será admissível, devendo tal elemento de prova ser excluído dos autos, ainda que a prova seja considerada relevante para o deslinde do feito ${ }^{282}$.

Entretanto, a despeito de todas essas mudanças é imperioso observar que a Corte de Apelação inglesa mantém firme entendimento de que a inobservância das regras estabelecidas no PACE não implica a exclusão automática e de imediato do elemento de prova em questão, devendo a solução ser dada na análise do caso a caso ${ }^{283}$, mantendo-se portanto, como regra, a admissibilidade da prova ilícita nos autos.

\section{1 “Art. 76 PACE}

Confessions.

(1) In any proceedings a confession made by an accused person may be given in evidence against him in so far as it is relevant to any matter in issue in the proceedings and is not excluded by the court in pursuance of this section.

(2) If, in any proceedings where the prosecution proposes to give in evidence a confession made by an accused person, it is represented to the court that the confession was or may have been obtained

(a) by oppression of the person who made it; or

(b) in consequence of anything said or done which was likely, in the circumstances existing at the time, to render unreliable any confession which might be made by him in consequence thereof,

the court shall not allow the confession to be given in evidence against him except in so far as the prosecution proves to the court beyond reasonable doubt that the confession (notwithstanding that it may be true) was not obtained as aforesaid.

(3) In any proceedings where the prosecution proposes to give in evidence a confession made by an accused person, the court may of its own motion require the prosecution, as a condition of allowing it to do so, to prove that the confession was not obtained as mentioned in subsection (2) above.

(4) The fact that a confession is wholly or partly excluded in pursuance of this section shall not affect the admissibility in evidence

(a) of any facts discovered as a result of the confession; or

(b) where the confession is relevant as showing that the accused speaks, writes or expresses himself in a particular way, of so much of the confession as is necessary to show that he does so.

(5) Evidence that a fact to which this subsection applies was discovered as a result of a statement made by an accused person shall not be admissible unless evidence of how it was discovered is given by him or on his behalf.

(6) Subsection (5) above applies

(a) to any fact discovered as a result of a confession which is wholly excluded in pursuance of this section; and

(b) to any fact discovered as a result of a confession which is partly so excluded, if the fact is discovered as a result of the excluded part of the confession.

(7) Nothing in Part VII of this Act shall prejudice the admissibility of a confession made by an accused person.

(8) In this section "oppression" includes torture, inhuman or degrading treatment, and the use or threat of violence (whether or not amounting to torture).

(9) Where the proceedings mentioned in subsection (1) above are proceedings before a magistrates' court inquiring into an offence as examining justices this section shall have effect with the omission of

(a) in subsection (1) the words "and is not excluded by the court in pursuance of this section", and

(b) subsections (2) to (6) and (8)".

${ }^{282}$ UGLOW, Steve. Issues in Evidence in English Criminal Law, p. 173-174.

${ }^{283}$ Conforme ASHWORTH, Andrew. The Criminal Process: An Evaluative Study, p. 109. 
Ademais, as disposições normativas disciplinando o interrogatório realizado em sede investigativa tampouco impedem a admissão pelos Tribunais das confissões ditas espontâneas, feitas na viatura policial, por exemplo ${ }^{284}$.

Ainda a respeito das regras de exclusão de prova o sistema inglês prevê o artigo 78 (1) do $\mathrm{PACE}^{285}$.

De acordo com tal dispositivo legal o meio de prova poderá ser excluído se ficar demonstrado à Corte que, de acordo com as circunstâncias do caso, inclusive as circunstâncias nas quais o meio de prova foi obtido, a admissão do meio de prova poderia ter um efeito tão adverso sobre a administração da justiça que a Corte não deva admiti-lo. "Ainda assim, tal dispositivo tem recebido uma interpretação restritiva, sendo aplicado apenas em situações de violações muito graves de direitos humanos". ${ }^{286}$

Assim, em que pese as mitigações conferidas pelo PACE, dentre outros diplomas normativos à teoria do male captum, bene retentum, constata-se que no sistema inglês a regra permanece sendo a da admissibilidade e valoração da prova obtida por meios ilícitos nos autos do processo seja em relação à ilicitude inicial ou em relação à ilicitude derivada. De forma que, quando verificada a exclusão de prova naquele sistema judicial, geralmente ocorre em razão da falta de confiabilidade no valor probatório do meio de prova em questão e não em face de ilegalidades verificadas em sua obtenção ${ }^{287}$. Vigendo, portanto, no sistema inglês a admissibilidade da prova ilícita por derivação, como regra.

Cumpre observar, por oportuno, que desde outubro de 2000 está em vigor na Inglaterra o Human Rights Act de 1998, o qual incorporou àquele sistema o direito ao fair trial, previsto no artigo $6^{\circ}$ da Convenção Européia de Direitos Humanos ${ }^{288}$.

\footnotetext{
${ }^{284}$ UGLOW, Steve. Issues in Evidence in English Criminal Law, p. 174.

285 “Art. 78 PACE
}

Exclusion of unfair evidence.

(1) In any proceedings the court may refuse to allow evidence on which the prosecution proposes to rely to be given if it appears to the court that, having regard to all the circumstances, including the circumstances in which the evidence was obtained, the admission of the evidence would have such an adverse effect on the fairness of the proceedings that the court ought not to admit it.

(2) Nothing in this section shall prejudice any rule of law requiring a court to exclude evidence.

(3) This section shall not apply in the case of proceedings before a magistrates' court inquiring into an offence as examining justices".

286 ÁVILA, Thiago André Pierobom. Provas ilícitas e Proporcionalidade, p. 191.

287 ÁVILA, Thiago André Pierobom. Provas ilícitas e Proporcionalidade, p. 191.

${ }^{288}$ ASHWORTH, Andrew. The Criminal Process: An Evaluative Study, p. 108. 
Portanto, poderá o magistrado ao julgar um caso concreto preterir os precedentes da Common Law que estiverem em desacordo com o quanto estabelecido na Convenção, alterando o sistema vigente ${ }^{289}$.

${ }^{289}$ ÁVILA, Thiago André Pierobom. Provas ilícitas e Proporcionalidade, p. 191. 


\section{A DISCIPLINA DA PROVA ILÍCITA NO BRASIL}

\subsection{Histórico e evolução}

Até o advento da Constituição Federal de 1988 inexistia qualquer norma positivada em nosso ordenamento jurídico versando acerca da ilicitude probatória ${ }^{290}$.

Assim, em um primeiro momento vigia nessa matéria o "princípio da veracidade da prova”, segundo o qual a prova era analisada conforme a sua força probante, sem levar em consideração a sua forma de obtenção. Eventuais irregularidades na obtenção das fontes de prova eram apuradas em órbita própria, como ilícitos administrativos ou penais, não influenciando em sua admissibilidade no processo $^{291}$.

Ademais, argumentava-se com base no princípio do livre convencimento judicial e da fé pública a admissibilidade de tais provas nos autos do processo ${ }^{292}$. Ou seja, afirmava-se existir a presunção relativa da licitude da prova, posto que obtida por agentes estatais, possuidores de fé pública. Além disso, sustentava-se que, de qualquer forma, quando da valoração probatória o juiz poderia apenas considerar as provas lícitas.

O sistema então vigente aproximava-se da idéia do male captum, bene retentum, possibilitando o ingresso dos elementos de prova nos autos do processo, independentemente de sua obtenção irregular ${ }^{293}$.

Entretanto, a partir do final da década de 60, verifica-se tendência por parte do Tribunal de Justiça de São Paulo de mudança de posicionamento ${ }^{294}$, no que foi acompanhado, anos mais tarde, pelo Supremo Tribunal Federal.

\footnotetext{
${ }^{290}$ GRINOVER, Ada Pellegrini. Liberdades Públicas e Processo Penal: as interceptações telefônicas, p. 159.

291 CARVALHO, Ricardo Cintra Torres de. A inadmissibilidade da prova ilícita em processo penal: um estudo comparativo das posições brasileira e norte-americana. Revista Brasileira de Ciências Criminais, São Paulo, v. 3, n. 12, out./dez. 1995, p. 162-200.

292 GOMES, Luiz Flávio, Prova ilícita: direito à exclusão dos autos do processo ("exclusionary rule"). Disponível em: 〈http://www.lfg.com.br/public html/article.php?story20041008122122480p >. Acesso em: 15 set. 2010.

${ }^{293}$ Muitos são os julgados que retratam essa perspectiva anterior: RT 148/154; RT 175/523; RT 161/51.
} 
O STF decidiu à época, em dois julgados em matéria de família e em um julgado criminal, pela inadmissibilidade das provas obtidas por meios ilícitos, antes da existência de qualquer norma legal nesse sentido ${ }^{295}$.

No âmbito processual penal a primeira decisão do Supremo Tribunal Federal a reconhecer a inadmissibilidade da prova ilícita foi proferida em dezembro de 1986. Tratava-se de um caso de interceptação telefônica ilegal, no qual foi determinado o trancamento do inquérito policial, fundado em fontes de prova viciadas dali advindas. A fundamentação da decisão foi no sentido de que: "meios de prova ilícitos não podem servir de sustentação ao inquérito ou à ação penal",296.

Também Ada Pellegrini Grinover ${ }^{297}$, mesmo diante da ausência de disposição normativa sobre o tema, já defendia no final dos anos 70 e início dos anos 80, a inadmissibilidade dos elementos de prova nos autos do processo quando obtidos em violação a direitos materiais e à Lei Maior.

A autora preconizava que a ilicitude material da prova deveria conduzir necessariamente a uma inadmissibilidade processual, em razão da supremacia constitucional. Entendia, portanto, que se o elemento de prova fosse obtido em desacordo com o quanto previsto na Constituição Federal não poderia servir como meio de prova nos autos do processo. Ainda que sem embasamento normativo expresso, a autora fazia decorrer da inconstitucionalidade do ato a sua ilicitude e sua inadmissibilidade processual.

A partir da promulgação do texto proposto pela Assembléia Constituinte em 05 de outubro de 1988 passa-se a ter previsão expressa para a questão no ordenamento jurídico brasileiro, dentro do capítulo do texto constitucional que trata dos direitos e deveres individuais e coletivos, inserto no título dos direitos e garantias fundamentais ${ }^{298}$.

\footnotetext{
${ }^{294}$ CARVALHO, Ricardo Cintra Torres de. A inadmissibilidade da prova ilícita em processo penal: um estudo comparativo das posições brasileira e norte-americana, p. 169.

${ }^{295}$ RTJ 84/606. 110/798 e 122/47.

${ }^{296}$ RTJ 122/47.

${ }^{297}$ Liberdades Públicas e Processo Penal: as interceptações telefônicas, p. 160-167.

${ }^{298}$ Vale lembrar que a Constituição Federal de 1988 foi promulgada após um período de governos autoritários que caracterizaram os vinte anos de ditadura militar no país. A desconfiança em relação ao legislador infraconstitucional e a sensação então prevalente de que a inserção dos direitos no Texto Maior impediriam uma eventual corrosão das conquistas democráticas alcançadas fez com que se produzisse uma Constituição rígida e analítica, o que também se refletiu no campo dos direitos fundamentais. Nesse sentido vide: SARLET, Ingo Wolfgang. A eficácia dos direitos fundamentais. 8. ed. rev. e atual. Porto Alegre: Editora Livraria do Advogado, 2007, p. 77 ss.
} 
Conforme disposto no artigo $5^{\circ}$, inciso LVI, da Constituição Federal atual "são inadmissíveis, no processo, as provas obtidas por meios ilícitos" ${ }^{, 299}$.

O dispositivo vinha sendo aplicado em sua plenitude pelos Tribunais brasileiros desde a promulgação da Constituição. Contudo, a despeito disso, o legislador ordinário entendeu ser conveniente trazer para o ordenamento jurídico brasileiro um conceito legal para "provas ilícitas".

Assim, em 03 de fevereiro de 2000, o Ministro da Justiça à época, Senhor José Carlos Dias, instalou, por meio da Portaria Ministerial n ${ }^{\circ}$ 61/2000, uma Comissão de Juristas para apresentar propostas para a Reforma do Código de Processo Penal ${ }^{300}$.

Dentre as inúmeras alterações sugeridas pela renomada Comissão foi proposta nova redação para o artigo 157 do Código de Processo Penal ${ }^{301}$, trazendo a previsão de uma conceituação legal para provas ilícitas como àquelas obtidas em violação a princípios ou normas constitucionais ${ }^{302}$, vedando ainda, expressamente, a admissibilidade da prova ilícita por derivação nos autos do processo.

As justificativas para tal proposta de alteração legislativa são extraídas da própria Exposição de Motivos do Anteprojeto que tratava das provas penais. "Constituem (...) provas ilícitas as obtidas com violação do domicílio (art. $5^{\circ}$, XI, da CF) ou das comunicações (art. $5^{\circ}$, XII, da CF), as conseguidas mediante tortura ou maus tratos (art. $5^{\circ}$, III, da CF), as colhidas com infringência à intimidade (art. $5^{\circ}, \mathrm{X}, \mathrm{da} \mathrm{CF}$ ), etc. Diante disso, é oportuno que a lei processual penal fixe as balizas da regra constitucional de exclusão das provas ilícitas, em qualquer hipótese, conceituando-as e tomando posição quanto a sua admissibilidade e proibição de utilização, mesmo quando se trate da denominada prova ilícita por derivação, ou

\footnotetext{
${ }^{299} \mathrm{O}$ artigo $5^{\circ}$, inciso LVI da Constituição Federal será analisado de forma detida adiante.

${ }^{300}$ A ilustre Comissão de Juristas era presidida por Ada Pellegrini Grinover, secretariada por Petrônio Calmon Filho, e composta por Antonio Magalhães Gomes Filho, Antonio Scarance Fernandes, Luiz Flávio Gomes, Miguel Reale Júnior, Nilzardo Carneiro Leão, Rene Ariel Dotti (que, posteriormente, deixou a Comissão, sendo substituído por Rui Stoco), Rogério Lauria Tucci e Sidnei Beneti.

${ }^{301}$ A redação sugerida pela Comissão de Juristas para o artigo 157 do CPP foi a seguinte:

"Art. 157. São inadmissíveis, devendo ser desentranhadas do processo, as provas ilícitas, assim entendidas as obtidas em violação a princípios ou normas constitucionais.

$\S 1^{\circ}$ São também inadmissíveis as provas derivadas das ilícitas, quando evidenciado o nexo de causalidade entre umas e outras, e quando as derivadas não pudessem ser obtidas senão por meio das primeiras.

$\S 2^{\circ}$ Após o trânsito em julgado da decisão de desentranhamento da prova declarada ilícita, serão tomadas as providências para o arquivamento sigiloso em cartório.

$\S 3^{\circ} \mathrm{O}$ juiz que conhecer do conteúdo da prova declarada ilícita não poderá proferir a sentença”.

302 AMBOS, Kai; CHOUKR, Fauzi Hassan. A Reforma do Processo Penal no Brasil e na América Latina. São Paulo: Editora Método, 2001, p. 147.
} 
seja, da prova não ilícita por si mesma, mas conseguida por intermédio de informações obtidas por provas ilicitamente colhidas". 303

O Anteprojeto do Código de Processo Penal, que abarcava as propostas elaboradas por aquela Comissão de Juristas, no que diz respeito à matéria de provas, veio a constituir-se no Projeto de Lei ${ }^{\circ} 4.205 / 2001^{304}$.

Embora a Comissão constituída pelo Ministro José Carlos Dias ${ }^{305}$ para propor reformas ao Código fosse presidida pela professora Ada, a principal responsável pela difusão no Brasil dos conceitos idealizados por Nuvolone, o Projeto inicial sofreu diversas alterações no Congresso Nacional, dando origem à Lei $\mathrm{n}^{\circ}$ 11.690/08, que acabou por não acompanhar às definições do doutrinador italiano.

De fato, a Lei $\mathrm{n}^{\mathrm{o}}$ 11.690/08 entrou em vigor em 10 de agosto de 2008, conferindo nova redação ao artigo 157, caput, do Código de Processo Penal.

O referido dispositivo trouxe um conceito legal para provas ilícitas, como sendo aquelas que "são obtidas em violação a normas constitucionais ou legais", pouco importando se tais normas tutelam direitos fundamentais ou quaisquer outros, ou se são normas de natureza material ou não, gerando grande desconforto em intérpretes e aplicadores do dispositivo, como será analisado no item 3.3.1 do trabalho.

No mesmo ano de 2008 foi constituída nova Comissão de Juristas ${ }^{306}$ a partir do Requerimento do Senado $n^{\circ}$ 227/08, assinado pelo presidente da Casa, o Senador José Sarney e aditado pelos Requerimentos de no 751 e 794/08, de autoria do Senador Renato Casagrande,

\footnotetext{
${ }^{303}$ Mensagem 211, MJ, Diário da Câmara dos Deputados, de 30 mar. 2001, p. 9474. Disponível em: <http://imagem.camara.gov.br/diarios.asp>. Acesso em: 19 ago. 2010.

${ }^{304}$ Conforme destaca MOREIRA, Rômulo de Andrade. A Reforma do Código de Processo Penal. Disponível em $<$ http://www1.jus.com.br/DOUTRINA/texto.asp?id=2572 >. Acesso em: 20 ago. 2010: "Ao final dos trabalhos, a Comissão de juristas entregou ao Ministério da Justiça, no dia 06 de dezembro de 2000, sete anteprojetos (todos acompanhados de uma exposição de motivos) que, por sua vez, originaram os seguintes projetos de lei: $1^{\circ}$.) Projeto de lei $\mathrm{n}^{\circ}$. 4.209/01: investigação criminal; $2^{\circ}$.) Projeto de lei $\mathrm{n}^{\circ}$. 4.207/01: suspensão do processo/procedimentos; $3^{\circ}$.) Projeto de lei $\mathrm{n}^{\circ}$. 4.205/01: provas; $4^{\circ}$.) Projeto de lei $\mathrm{n}^{\circ}$. 4.204/01: interrogatório/defesa legítima; $5^{\circ}$.) Projeto de lei $\mathrm{n}^{\circ}$. 4.208/01: prisão/medidas cautelares e liberdade; $6^{\circ}$.) Projeto de lei $n^{\circ}$. 4.203/01: júri; $7^{\circ}$.) Projeto de lei $n^{\circ}$. 4.206/01: recursos e ações de impugnação".

${ }^{305}$ Com a saída do Ministro José Carlos Dias, o novo titular da Pasta, Dr. José Gregori, confirmou a Comissão anteriormente formada, com a substituição já referida, a partir da edição da Portaria Ministerial $n^{\circ}$ 371/00.

${ }^{306}$ A Comissão de Juristas escolhida para elaborar um Anteprojeto de Reforma do Código de Processo Penal era coordenada por Hamilton Carvalhido, tendo como relator Eugênio Pacelli de Oliveira e composta por Antonio Correa, Antonio Magalhães Gomes Filho, Fabiano Augusto Martins Silveira, Felix Valois Coelho Júnior, Jacinto Nelson de Miranda Coutinho, Sandro Torres Avelar e Tito Souza do Amaral. A Assessoria Técnica era exercida por Edilenice Passos e secretariada por Dulcídia F. Ramos Calhao.
} 
tendo sido a referida Comissão designada pelos Atos do Presidente do Senado de $\mathrm{n}^{\mathrm{o}} 11,17$ e 18/08, para elaboração de Anteprojeto de Reforma do Código de Processo Penal.

Este Anteprojeto visava à revogação do Código de 1941, ainda vigente, e não apenas a sua revisão, como ocorreu com a aprovação das Leis no 11.689/08, 11.690/08 e 11.719/08.

No que tange à problemática da prova ilícita, essa nova Comissão de juristas propôs a seguinte redação para o tema:

“Art. 164. São inadmissíveis as provas obtidas, direta ou indiretamente, por meios ilícitos.

Parágrafo único. A prova declarada inadmissível será desentranhada dos autos e arquivada sigilosamente em cartório".

O dispositivo proposto, que será estudado adiante, integra o PLS n n $^{\text {156/09, }}$ posteriormente substituído por outro Projeto de autoria do Senador Renato Casagrande na Comissão de Constituição e Justiça do Senado. Atualmente encontra-se em votação no Congresso Nacional.

\subsection{Análise do artigo $5^{\circ}$, inciso LVI, da Constituição Federal}

\subsubsection{Considerações prévias}

Feita a análise da evolução histórica do regramento da ilicitude probatória no sistema processual penal brasileiro, serão analisadas as disposições normativas acerca do tema, começando pela disposição constitucional, para então abordar as previsões legais infraconstitucionais e a redação conferida à questão da prova ilícita no Projeto de Novo Código de Processo Penal. 
Contudo, para uma melhor análise do quanto disposto no artigo $5^{\circ}$, inciso LVI, da Constituição Federal: sua natureza jurídica, classificação e alcance de proteção é necessário repassar alguns conceitos prévios.

Assim, mister revisitar as distinções existentes entre regras e princípios mencionadas pela doutrina, a fim de determinar a natureza jurídica da norma inserta no artigo $5^{\circ}$, inciso LVI, da Constituição Federal.

Ademais, por ser um tema correlato da mais alta relevância e, de modo a fornecer elementos necessários para assuntos desenvolvidos no trabalho, convém tratar, de forma resumida, acerca da proporcionalidade.

\subsubsection{Regras e princípios}

Segundo a doutrina tradicional, as normas dividem-se em regras e em princípios $^{307}$.

As regras se refeririam a prescrições de comportamentos bem definidas, obrigando, permitindo ou proibindo condutas. Já os princípios trariam previsões mais genéricas, redigidos em termos particularmente vagos, sem definição direta de seu destinatário.

Costuma-se dizer que os princípios sejam normas com grau de abstração relativamente elevado, enquanto as regras teriam abstração reduzida.

Os princípios seriam carecedores de mediações concretizadoras tanto pelo legislador quanto pelo aplicador da lei, ao passo que as regras seriam suscetíveis de aplicação direta.

Princípios seriam considerados standards jurídicos ligados a idéia de "Justiça" e de "Direito", sendo que as regras, por sua vez, poderiam ser normas vinculativas com conteúdo meramente formal.

\footnotetext{
${ }^{307}$ Vide a respeito BONAVIDES, Paulo. Curso de Direito Constitucional. 19. ed. São Paulo: Editora Malheiros, 2006, p. 255-295 e ALEXY, Robert. Teoria dos Direitos Fundamentais, p. 86-90. Em sentido contrário, sustentando a existência de distintas espécies normativas vide ÁVILA, Humberto. Teoria dos Princípios: da definição à aplicação dos princípios jurídicos. 11. ed. rev. São Paulo: Editora Malheiros, 2010, p. 26-27.
} 
Além disso, sustenta-se também que os princípios, em virtude de sua posição hierárquica no sistema das fontes do Direito, poderiam ser vistos como fundamento das $\operatorname{regras}^{308}$.

Sob o enfoque da teoria dos princípios na perspectiva de Robert Alexy são também as normas divididas em regras e em princípios, entretanto a distinção não está no grau de abstração ou concretude da disposição normativa, ou em quaisquer dos critérios $\operatorname{expostos}^{309}$.

De acordo com Alexy a distinção entre regras e princípios não é uma mera distinção de grau, mas de qualidade normativa. Na visão do autor essa diferenciação entre as díspares espécies de normas terá implicação direta nos mecanismos de solução aplicáveis ao caso concreto na hipótese de se verificar uma colisão entre normas princípios ou um conflito entre normas regras.

Conforme sustenta Alexy, princípios são normas que ordenam que algo seja realizado na maior medida possível, dentro das possibilidades jurídicas e fáticas existentes. São os princípios, portanto, mandamentos de otimização, caracterizados pelo fato de que podem ser cumpridos em diferentes graus e que a medida do seu cumprimento depende não apenas das possibilidades concretas de sua efetivação, como também das possibilidades jurídicas $^{310}$. Ou seja, princípios são razões prima facie $^{311}$.

Segundo o autor, quando entram em colisão dois princípios opostos e igualmente válidos no ordenamento jurídico, para saber qual será aplicável é preciso balanceálos e identificar, no caso concreto, qual será o princípio de maior peso. Este balanceamento de princípios é feito através da utilização da proporcionalidade ${ }^{312}$.

Diferentemente dos princípios, as regras são aplicadas mediante subsunção. São normas que podem sempre ser cumpridas ou não. Ou seja, quando uma regra vale, obrigatoriamente há de se conduzir conforme ela determina. "Regras contêm, portanto,

\footnotetext{
${ }^{308}$ CANOTILHO, José Joaquim Gomes. Direito Constitucional. 6. ed. Coimbra: Almedina, 1993, p. 166-167.

${ }^{309}$ ALEXY, Robert. Teoria dos Direitos Fundamentais, p. 90.

${ }^{310}$ ALEXY, Robert. Teoria dos Direitos Fundamentais, p. 90.

${ }^{311}$ ALEXY, Robert. Teoria dos Direitos Fundamentais, p. 106-107.

312 Conforme SILVA, Virgílio Afonso da. Direitos Fundamentais: conteúdo essencial, restrições e eficácia. 2. ed. São Paulo: Malheiros, 2010, p. 178-179. Segundo explana o autor a proporcionalidade deverá ser utilizada no processo de controle de constitucionalidade de leis restritivas de direitos fundamentais. Já na hipótese de utilização direta de princípios constitucionais colidentes e potencialmente aplicáveis ao caso concreto que não tenham sido ainda objeto de ponderação pelo legislador deverá o intérprete fazer apenas o sopesamento dos princípios em jogo para decidir qual será o de maior peso no caso concreto.
} 
determinações no âmbito daquilo que é fática e juridicamente possível". ${ }^{313}$ Assim, se não houver o estabelecimento de alguma exceção, as regras serão razões definitivas ${ }^{314}$.

Nos dizeres de Ronald Dworkin as regras são aplicadas ou não no caso concreto, seguindo a ordem do "tudo ou nada", ou seja, ou a regra é válida e então deverá ser aceita, ou não é válida e, portanto em nada contribuirá para a decisão do caso concreto ${ }^{315}$.

No caso de verificarmos um conflito aparente de duas regras apenas uma será aplicável ao caso, sendo a outra desconsiderada. O conflito poderá ser solucionado com a introdução de uma cláusula de exceção à regra ou com a declaração de nulidade de alguma das regras conflitantes. São utilizáveis também para o mesmo propósito as máximas de que "lei posterior revoga lei anterior", "lei especial revoga lei geral" e "lei hierarquicamente superior revoga lei inferior" ${ }^{316}$.

Já os princípios, em sendo caso de colisão, serão aplicáveis na maior medida possível. Entretanto, isso não significa que o princípio não prevalente no caso concreto tenha perdido sua validade no ordenamento jurídico, ao revés é perfeitamente verificável que em outra situação seja aplicável o princípio preterido em caso concreto anterior.

Os princípios, diferentemente das regras, possuiriam a dimensão do peso ou importância $^{317}$.

Humberto Ávila critica o modelo proposto por Alexy, sugerindo as seguintes definições para regras e princípios: "As regras são normas imediatamente descritivas, primariamente retrospectivas e com pretensão de decidibilidade e abrangência, para cuja aplicação se exige a avaliação da correspondência, sempre centrada na finalidade que lhes dá suporte ou nos princípios que lhes são axiologicamente sobrejacentes, entre a construção conceitual da descrição normativa e a construção conceitual dos fatos. Os princípios são normas imediatamente finalísticas, primariamente prospectivas e com pretensão de complementariedade e de parcialidade, para cuja aplicação se demanda uma avaliação da

\footnotetext{
${ }^{313}$ ALEXY, Robert. Teoria dos Direitos Fundamentais, p. 91.

${ }^{314}$ ALEXY, Robert. Teoria dos Direitos Fundamentais, p. 106-107.

${ }^{315}$ DWORKIN, Ronald. Levando os direitos a sério. Tradução de Nelson Boeira. São Paulo: Editora Martins Fontes, 2002, p 39.

${ }^{316}$ ALEXY, Robert. Teoria dos Direitos Fundamentais, p. 92-93. Vide também DWORKIN, Ronald. Levando os direitos a sério, $\mathrm{p} 43$.

${ }^{317}$ DWORKIN, Ronald. Levando os direitos a sério, p 42.
} 
correlação entre o estado de coisas a ser promovido e os efeitos decorrentes da conduta havida como necessária à sua promoção". 318

Para o autor brasileiro, as regras são normas imediatamente descritivas, que estabelecem obrigações, permissões e proibições, já os princípios são normas imediatamente finalísticas, que estabelecem um estado das coisas para cuja realização é necessária a adoção de um dado comportamento ${ }^{319}$.

De acordo com Humberto Ávila a atividade de ponderação de valores, ou sopesamento, não é privativa da aplicação dos princípios, mas método cabível em qualquer aplicação de normas. Segundo o autor "somente mediante a ponderação de razões pode-se decidir se o aplicador deve abandonar os elementos da hipótese da regra em busca do seu fundamento, nos casos em que exista uma discrepância entre eles". ${ }^{320}$ Complementa o autor: “a ponderação diz respeito tanto aos princípios quanto às regras, na medida em que qualquer norma possui um caráter provisório que poderá ser ultrapassado por razões havidas como mais relevantes pelo aplicador diante do caso concreto. O tipo de ponderação é que é diverso". 321

$\mathrm{Ou}$ seja, nos casos em que a aplicação da regra conforme prevista no dispositivo normativo acabar por ferir a própria razão de existir da regra, a norma não deverá ser aplicada, pois razões da mais alta relevância no caso concreto apontarão para essa solução.

Para Humberto Ávila não é correto tampouco sustentar que apenas os princípios teriam uma dimensão de peso. Sustenta o autor que "a aplicação das regras exige o sopesamento de razões, cuja importância será atribuída (ou coerentemente intensificada) pelo aplicador. A dimensão axiológica não é privativa dos princípios, mas elemento integrante de qualquer norma jurídica". ${ }^{322}$ Ainda conforme o autor, a dimensão de peso não está incorporada a um tipo de norma específica, uma vez que as normas não regulam sua própria aplicação. Assim, é a decisão do aplicador da norma que atribui aos princípios, e também às regras, um peso determinado em função das circunstâncias concretas presentes no caso.

$\mathrm{O}$ autor sustenta ainda a superação do enfoque baseado na alternatividade das espécies normativas que seriam sempre ou regras ou princípios. Conforme o autor o mesmo

\footnotetext{
318 ÁVILA, Humberto. Teoria dos Princípios: da definição à aplicação dos princípios jurídicos, p. 78-79.

319 ÁVILA, Humberto. Teoria dos Princípios: da definição à aplicação dos princípios jurídicos, p. 71.

${ }^{320}$ ÁVILA, Humberto. Teoria dos Princípios: da definição à aplicação dos princípios jurídicos, , p. 58.

321 ÁVILA, Humberto. Teoria dos Princípios: da definição à aplicação dos princípios jurídicos, , p. 58-59.

322 ÁVILA, Humberto. Teoria dos Princípios: da definição à aplicação dos princípios jurídicos, p. 59.
} 
substrato normativo pode abarcar uma regra ou um princípio, conforme a interpretação e aplicação que seja dado ao mesmo. É o caráter pluridimensional dos enunciados normativos. Será considerado uma regra, se o caráter comportamental for privilegiado pelo intérprete em relação à finalidade que lhe dá suporte. Por sua vez será considerado um princípio se o aplicador ressaltar o aspecto valorativo para alcançar comportamentos inseridos em outro contexto $^{323}$.

Segundo a teoria de Robert Alexy apenas os princípios deverão ser sopesados, a partir da aplicação da proporcionalidade e aquele considerado de maior relevância para o caso concreto será o preponderante. É que, de acordo com o referido autor, conflitos de regras se desenrolam na dimensão da validade normativa, enquanto a colisão de princípios ocorre no âmbito do valor das normas ${ }^{324}$.

Para Humberto Ávila, entretanto, como já afirmado, a ponderação será sempre cabível na aplicação de normas, valendo tanto para regras quanto para princípios. Já a proporcionalidade somente será aplicada no caso de imbricamento de bens jurídicos em que exista uma relação de causalidade entre dois elementos empiricamente distintos, um meio e um fim ${ }^{325}$. Ou seja, para o autor casos de colisão de princípios em que não se verifique a relação meio e fim deverão ser solucionados mediante a aplicação de outros "postulados" normativos tais como a ponderação, a proibição do excesso, e não pela proporcionalidade ${ }^{326}$.

Seja como for, é de se notar que a aplicação ou não da proporcionalidade ocorrerá no caso concreto sob a regra do tudo ou nada, aproximando a proporcionalidade portanto, segundo a teoria defendida por Alexy, de uma regra ${ }^{327}$ e não de um princípio, como ficou doutrinariamente conhecida ${ }^{328}$.

${ }^{323}$ ÁVILA, Humberto. Teoria dos Princípios: da definição à aplicação dos princípios jurídicos, , p. 70-71.

${ }^{324}$ ALEXY, Robert. Teoria dos Direitos Fundamentais, p. 94.

325 ÁVILA, Humberto. Teoria dos Princípios: da definição à aplicação dos princípios jurídicos, p. 163-165.

326 ÁVILA, Humberto. Teoria dos Princípios: da definição à aplicação dos princípios jurídicos, p. 178-181.

${ }^{327}$ Nesse sentido SILVA, Virgílio Afonso da. Interpretação Constitucional e Sincretismo Metodológico. In: . (Org.). Interpretação Constitucional. São Paulo, Editora Malheiros, 2010, p. 128. Na página destacada o autor fala em "regra da proporcionalidade com suas três sub-regras". Também SIMONS, Christian Sthefan. A prova ilícita no direito processual penal norte-americano e alemão e as influências no processo penal brasileiro, p. 145. Em dado trecho o autor declara que a proporcionalidade tem natureza jurídica de regra hermenêutica. Assim, embora tradicionalmente a doutrina pátria identifique a proporcionalidade como um princípio, constituído pelos subprincípios da adequação, necessidade e proporcionalidade em sentido estrito é de se ressaltar que na obra de ALEXY, Robert. Teoria dos Direitos Fundamentais, p. 116 ss, com tradução feita por Virgílio Afonso da Silva é utilizada a denominação "máxima da proporcionalidade", mencionando ainda o autor que as máximas parciais que a compõem funcionam como regras. Em outra obra, SILVA, Virgílio Afonso da. Direitos Fundamentais: conteúdo essencial, restrições e eficácia, p. 168 explica que o termo máxima seria o utilizável em 


\subsubsection{Proporcionalidade}

A proporcionalidade ${ }^{329}$ se constitui na principal forma de controle às restrições aos direitos fundamentais ${ }^{330}$.

É adotada como instrumento eficaz de solução de colisão de princípios constitucionais ${ }^{331}$, servindo como limitador às restrições de direitos fundamentais.

De acordo com Robert Alexy a teoria dos princípios ${ }^{332}$ não diz que os direitos fundamentais não possam ser consubstanciados em normas que tenham a natureza jurídica de regras, mas que estas sempre terão ao seu lado ou por detrás de si princípios, que, por sua vez, poderão ser sopesados no caso de colisões com outros princípios ${ }^{333}$.

uma tradução direta do alemão, mas que em vista de não ser comumente empregado no Brasil é melhor adotar a nomenclatura "regra da proporcionalidade", entendida esta como uma regra especial, uma regra de segundo nível ou uma meta-regra, na medida em que se constitui em uma regra sobre a aplicação de outras regras e não em uma regras de conduta ou de competência. Destaque-se que GRAU, Eros Roberto. Ensaio e discurso sobre a interpretação/aplicação do direito. 4. ed. São Paulo: Malheiros, 2006, p. 189-191 salienta também a natureza de regra dos três elementos parciais que compõem a proporcionalidade, referindo-se a esta como postulado normativo de interpretação/aplicação do direito. ÁVILA, Humberto. Teoria dos Princípios: da definição à aplicação dos princípios jurídicos, p. 163, por sua vez, utiliza a expressão "postulado da proporcionalidade". Na página 71 o autor define postulados como "instrumentos normativos metódicos, isto é, como categorias que impõem condições a serem observadas na aplicação das regras e dos princípios, com eles não se confundindo". Isto posto, em conformidade com o rigor científico, não utilizaremos a expressão "princípio da proporcionalidade".

${ }^{328}$ Em sentido contrário, sustentando ser equivocada a classificação da proporcionalidade como regra: GUERRA FILHO, Willis Santiago. Princípio da Proporcionalidade e Devido Processo Legal. In: SILVA, Virgílio Afonso da (Org.). Interpretação Constitucional. São Paulo: Malheiros, 2005, p. 268-269.

${ }^{329}$ Vale frisar que a análise sucinta ora feita acerca da proporcionalidade visa fornecer elementos necessários para temas desenvolvidos no trabalho, não se constituindo em objeto desta dissertação propriamente.

${ }^{330}$ A regra da proporcionalidade tem como pressuposto um modelo de suporte fático amplo de direitos fundamentais, que não delimita a priori o âmbito de proteção dos direitos fundamentais, mas apenas indica uma possível proteção que somente será confirmada após o sopesamento feito no caso concreto. Além disso, pressupõe também a adoção da teoria externa, segundo a qual as restrições, independentemente de sua natureza, não influenciam sobre o conteúdo do direito, apenas o restringindo no caso concreto. Para mais explanações acerca das distinções entre suporte fático amplo e restrito de direitos fundamentais e teoria externa e interna (dos limites imanentes) vide: SILVA, Virgílio Afonso da. Direitos Fundamentais: conteúdo essencial, restrições e eficácia, p. 65 ss.

${ }^{331}$ Conforme ALEXY, Robert. Teoria dos Direitos Fundamentais, p. 102: "Mesmo que todas as normas de direitos fundamentais diretamente estabelecidas tivessem a estrutura de princípios - o que, como ainda será demonstrado, não ocorre -, ainda assim haveria normas de direitos fundamentais com a estrutura de princípios e normas de direitos fundamentais com a estrutura de regras".

${ }^{332}$ Sobre a teoria dos princípios e a proporcionalidade vide: ALEXY, Robert. Teoria dos Direitos Fundamentais, p. 116-118.

${ }^{33}$ Conforme explanado por Robert Alexy em palestra proferida na Fundação Casa de Rui Barbosa, no município do Rio de Janeiro em 10 de dezembro de 1998: "A teoria dos princípios não diz que o catálogo dos direitos 
A regra da proporcionalidade é composta por três elementos parciais, que nos dizeres de Robert Alexy funcionam também como regras ${ }^{334}$. São eles: a adequação, a necessidade e a proporcionalidade em sentido estrito. Esses elementos parciais, na ordem em que foram propostos, justificam e autorizam no caso concreto, uma restrição aos direitos fundamentais ${ }^{335}$ em detrimento de outro direito de mesma natureza e igualmente válido.

Pela análise da adequação, como primeiro requisito para que se admita uma restrição a um direito fundamental, deve-se verificar se a medida que se busca adotar é hábil a fomentar a consecução do resultado pretendido. Faz-se aqui, portanto, uma análise da referida medida em caráter absoluto, não comparativa.

Uma vez considerada adequada, passe-se a análise da máxima parcial da necessidade. Nesse ponto a medida restritiva será admitida como necessária se a realização do intento a que se visa alcançar não puder ser promovido, com a mesma intensidade, por outro meio menos restritivo do direito fundamental atingido. São, portanto, feitas duas análises comparativas: a primeira em relação a eficiência das medidas na concretização do objetivo proposto e a segunda leva em conta o grau de restrição a que submetem o direito atingido. Assim, será necessária a medida mais eficiente e menos restritiva.

A medida necessária será então objeto de análise da proporcionalidade em sentido estrito. Nesse passo, os direitos fundamentais em colisão no caso concreto serão balanceados, decidindo-se qual prevalecerá, ou seja, qual direito impelirá a medida restritiva sobre o outro, se sobrepondo a ele. Essa última etapa da aplicação da regra da proporcionalidade visa evitar que medidas estatais, que embora sejam consideradas adequadas e necessárias, restrinjam direitos fundamentais para além do justificável em face do intento buscado.

fundamentais não contém regras; isto é, que ele não contém definições precisas. Ela afirma não apenas que os direitos fundamentais, enquanto balizadores de definições precisas e definitivas, têm estrutura de regras, como também acentua que o nível de regras precede prima facie ao nível de princípios. O seu ponto decisivo é o de que atrás e ao lado das regras existem os princípios. O contraponto para a teoria dos princípios não é, portanto, uma teoria que supõe que o catálogo dos direitos fundamentais também contêm regras, senão uma teoria que afirma que os direitos fundamentais contêm somente regras". O trecho foi traduzido e transcrito pelo primeiro autor em obra coletiva: MENDES, Gilmar Ferreira; COELHO, Inocêncio Mártires; BRANCO, Paulo Gustavo Gonet. Curso de Direito Constitucional. 4. ed. rev. e atual. São Paulo: Saraiva, 2009, p. 335, nota de rodapé n. 33.

${ }^{334}$ ALEXY, Robert. Teoria dos Direitos Fundamentais, p. 117.

${ }^{335}$ Acerca dos direitos fundamentais e suas restrições vide ALEXY, Robert. Teoria dos Direitos Fundamentais, p. 276-285. 
Para Nicolas Gonzalez-Cuellar Serrano ${ }^{336}$, a proporcionalidade deve respeitar ainda para a sua aplicação os pressupostos formal da legalidade e material da motivação teleológica, bem como os requisitos intrínsecos da adequação, necessidade e proporcionalidade em sentido estrito, além dos requisitos extrínsecos da motivação e da judicialidade.

De qualquer modo, certo é que as máximas parciais da proporcionalidade devem ser examinadas pelo aplicador da lei diante do caso concreto, possuindo ele todos os dados fáticos necessários ao juízo de ponderação, de forma a possibilitar uma avaliação criteriosa antes de ser efetivada a restrição de direitos fundamentais de um indivíduo. Ou seja, a análise dos elementos componentes da proporcionalidade não deve ser feita de forma teórica, em abstrato, mas só diante do caso concreto ${ }^{337}$.

Ademais, é importante mencionar que, no que diz respeito ao sistema criminal, a aplicação da proporcionalidade além de se constituir em uma garantia do indivíduo face ao Estado, trazendo verdadeiros limites a aplicação do ius puniendi, que só será legítimo na medida em que tal atuação seja considerada proporcional (é a acepção do princípio da proporcionalidade como garantidor da proibição do excesso $^{338}$, tutelando direitos fundamentais e suas restrições), em épocas mais recentes têm se sustentado que a proporcionalidade traga em si também outro viés que não esse de limitador da atuação estatal.

Segundo esta concepção, a proporcionalidade comportaria também um verdadeiro comando para que o Estado atue em determinadas situações, de forma a assim melhor tutelar certos direitos, também considerados fundamentais. É a acepção da

\footnotetext{
${ }^{336}$ SERRANO, Nicolas Gonzalez-Cuellar. Proporcionalidad y derechos fundamentales en el processo penal, $\mathrm{p}$. 69-113 e 141-242.

${ }^{337}$ A esse respeito vale conferir as explicações feitas por SILVA, Virgílio Afonso da. Direitos Fundamentais: conteúdo essencial, restrições e eficácia, p. 140, nota de rodapé n. 64, acerca do significado de "caso concreto".

${ }^{338}$ Em sentido contrário, distinguindo os conceitos de proporcionalidade e proibição do excesso, vide: ÁVILA, Humberto. Teoria dos Princípios: da definição à aplicação dos princípios jurídicos, p. 147-148. Segundo o autor: "A proibição de excesso está presente em qualquer contexto em que um direito fundamental esteja sendo restringido. Por isso, deve ser investigada separadamente do postulado da proporcionalidade: sua aplicação não pressupõe a existência de uma relação de causalidade entre meio e um fim. O postulado da proibição de excesso depende, unicamente, de estar um direito fundamental sendo excessivamente restringido". A despeito da distinção feita pelo autor, o mesmo reconhece a página 147 da referida obra, que o Supremo Tribunal Federal trata da proibição de excesso como uma das facetas da proporcionalidade.
} 
proporcionalidade como proibição da proteção insuficiente ${ }^{339}$, da qual seriam exemplos os mandados de criminalização constitucional.

No que atine à questão das provas ilícitas vale ressaltar que a proporcionalidade e o sopesamento de bens são freqüentemente invocados como mecanismos aptos a flexibilizar a rigidez da norma inserta no artigo $5^{\circ}$, inciso LVI, da Constituição Federal, especialmente no que diz respeito à prova ilícita inicial, que, uma vez aceita, acaba por permitir também a inserção nos autos do processo de provas dela derivadas.

De fato, a partir da adoção da proporcionalidade, a doutrina ${ }^{340}$ e a Jurisprudência $^{341}$ pátrias amplamente majoritárias, têm aceitado os elementos de prova obtidos ao arrepio da lei quando aptos a beneficiar a defesa no caso de acusações injustas.

Um exemplo seria a admissibilidade do meio de prova, ainda que fruto de alguma ilicitude (uma gravação clandestina de uma conversa telefônica, por exemplo) se esse fosse o único modo de se provar a inocência do réu. Trata-se da realização do sopesamento dos bens jurídicos em conflito, concedendo maior relevância à liberdade do indivíduo do que à vedação às provas ilícitas e à intimidade do segundo falante, na conversa gravada.

A análise aqui se coloca entre a vedação à admissão das provas ilícitas nos autos do processo e o direito à liberdade individual. Por certo, se para evitar a condenação de um inocente for imprescindível o uso da prova ilícita, esta deverá excepcionalmente ser admitida.

São as chamadas "provas ilícitas pro reo" - nome objetado em parte, sob o argumento de que a legítima defesa ou o estado de necessidade, presentes no caso concreto, funcionariam como verdadeiras causas de excludentes de ilicitude, tornando a prova legal ${ }^{342}$. De fato, a prova seria plenamente aceita, sendo considerada um exercício de legítima defesa

${ }^{339}$ Conforme CHINELATO, João Marcelo Torres. O princípio da proporcionalidade proibindo a omissão Estatal: por uma hermenêutica comprometida com a integridade dos direitos fundamentais. Disponível em <http://jus2.uol.com.br/doutrina/texto.asp?id=9889>. Acesso em: 18 out. 2010.

${ }^{340}$ Vide nesse sentido, dentre outros: GRINOVER, Ada Pellegrini; FERNANDES, Antonio Scarance; GOMES FILHO, Antonio Magalhães. As Nulidades no Processo Penal, p. 162; MENDONÇA, Andrey Borges de. Nova Reforma do Código de Processo Penal. 2. ed. São Paulo: Editora Método, 2009, p. 166 e GOMES, Luiz Flávio; CUNHA, Rogério Sanches; PINTO, Ronaldo Batista. Comentários às Reformas do Código de Processo Penal e da Lei de Trânsito, p. 282-283.

${ }^{341}$ Nesse sentido: STF HC 74.678 SP, Relator Ministro Moreira Alves, DJ 15.08.1997, STF HC 75.261 MG, Relator Ministro Octávio Galloti, DJ 22.08.1997; STF RE 212.081 RO Relator Ministro Octávio Galloti, DJ 27.03.1998, dentre outros.

${ }^{342}$ GRINOVER, Ada Pellegrini; FERNANDES, Antonio Scarance; GOMES FILHO, Antonio Magalhães. As Nulidades no Processo Penal, p. 162 e OLIVEIRA, Eugênio Pacelli de. Curso de Processo Penal, p. 317. 
ou de estado de necessidade perdendo, portanto, a característica inicial da ilicitude ao ser amparada por uma excludente de antijuridicidade.

Segundo Aury Lopes Júnior é perfeitamente sustentável também a tese da inexigibilidade de conduta diversa, excluindo a culpabilidade da conduta, o que segundo o autor concederia legitimidade à fonte de prova obtida ${ }^{343}$.

Assim, a proporcionalidade tem sido aplicada e aceita em matéria de provas ilícitas, quando o sopesamento de bens prioriza o direito à liberdade.

No que diz respeito à utilização da máxima da proporcionalidade para ensejar a admissão de provas ilícitas em favor do órgão acusador entende-se pela impossibilidade de sua $\operatorname{adoção~}^{344}$.

A Constituição Federal é categórica em afirmar que a presunção é de que o acusado seja inocente, fixando, conseqüentemente, a regra de julgamento do in dubio pro reo. Assim cabe ao Ministério Público ou ao ofendido (em caso de crimes de ação penal privada) provar, valendo-se apenas de meios de prova legais, a imputação delitiva e caso não se desincumba desse mister deverá o julgador absolver o réu. É que em um Estado Democrático de Direito a liberdade individual deverá ser considerada mais relevante do que a punição a qualquer preço $^{345}$.

Entretanto vale notar que, a despeito do referido posicionamento, não faltam defensores da aceitação da prova ilícita para beneficiar a acusação ${ }^{346}$.

\footnotetext{
343 JÚNIOR, Aury Lopes. Direito Processual Penal e sua Conformidade Constitucional. v. I, p. 588.

${ }^{344}$ Também nesse sentido: SOUZA, Sérgio Ricardo de. Manual da Prova Penal Constitucional: Pós Reforma de 2008 atualizado de acordo com as Leis 11.689/08 e 11.690/08. Curitiba: Juruá, 2008, p. 53-54; JÚNIOR, Aury Lopes. Direito Processual Penal e sua Conformidade Constitucional. v. I, p. 586-587 e GOMES FILHO, Antonio Magalhães. A inadmissibilidade das provas ilícitas no processo penal brasileiro. Revista Brasileira de Ciências Criminais, São Paulo, ano 18, n. 85, jul./ago. 2010, p. 408-409.

${ }^{345}$ Conforme HECK, Luís Afonso. Regras, princípios jurídicos e sua estrutura no pensamento de Robert Alexy. In: LEITE, George Salomão (Org.). Dos princípios constitucionais: Considerações em torno das normas principiológicas da Constituição. São Paulo: Malheiros, 2003, p. 100. Explanando o pensamento de Robert Alexy afirma Luís Afonso Heck: "A teoria dos princípios como teoria formal, sozinha, não basta. Deve acrescer uma teoria substancial de direitos individuais. A idéia de uma primazia-prima facie de direitos individuais diante de bens coletivos é um elemento essencial de uma tal teoria".

${ }^{346}$ Utilizando a proporcionalidade para admitir provas ilícitas favoráveis à acusação nos autos do processo, vide: SILVA, César Dario Mariano da. Provas Ilícitas, p. 31; MELLO, Fábia Amaral de Oliveira. A prova ilícita e a possibilidade de sua aplicação no processo penal. Revista da ESMAPE, Recife, v. 7, n. 15, jan./jun. 2002, p. 259263; CARNAÚBA, Maria Cecília Pontes. Prova ilícita. São Paulo: Editora Saraiva, 2000, p. 83-92; MOREIRA, José Carlos Barbosa. A Constituição e as provas ilicitamente obtidas. Revista Forense, Rio de Janeiro, v. 93, n. 337, jan./mar. 1997, p. 125-134; PRADO, Leandro Cadenas. Provas Ilícitas: Teoria e Interpretação dos Tribunais Superiores, p. 33; OLIVEIRA, Eugênio Pacelli de. Curso de Processo Penal, p. 322.
} 
No entender de Antonio Scarance Fernandes ${ }^{347}$, a questão não está em utilizar a proporcionalidade para a obtenção de provas ilícitas em favor da defesa ou da acusação, mas em se verificar, no caso concreto, se a restrição ao direito fundamental não prevalente na hipótese é adequada, necessária e proporcional em sentido estrito.

Cumpre notar ainda que a proporcionalidade é instrumento hábil para a solução de colisões de direitos fundamentais independentemente de tal possibilidade vir expressamente prevista em uma norma legal, uma vez que sua aplicação decorre do próprio regime de direitos fundamentais ${ }^{348}$.

Por certo, tal instrumento será sempre aplicável, desde que verificados seus pressupostos no caso concreto, sendo irrelevante a existência de norma legal prevendo expressamente sua aplicação ${ }^{349}$. Essa afirmação é também válida em matéria de prova originalmente ilícita no ordenamento processual penal brasileiro.

\subsubsection{Natureza jurídica}

Feitas as necessárias considerações passe-se a analisar a norma inserta no artigo $5^{\circ}$, inciso LVI, da Constituição Federal, a começar pela sua natureza jurídica.

Como já salientado, o direito à prova emerge da garantia constitucional ao contraditório, adquirindo também status constitucional, como o direito de atuar e influir sobre o resultado do processo ${ }^{350}$. É consubstanciado como conseqüência lógica do direito ao acesso ao Judiciário, expresso nos direitos de ação e de defesa ${ }^{351}$.

\footnotetext{
347 FERNANDES, Antonio Scarance. Processo Penal Constitucional. 6. ed. São Paulo: Editora Revista dos Tribunais, 2010, p. 86.

${ }^{348}$ Conforme ALEXY, Robert. Teoria dos Direitos Fundamentais, p. 116-120. Versando também acerca do reconhecimento da proporcionalidade no direito brasileiro a despeito de sua falta de previsão expressa, vide: GUERRA FILHO, Willis Santiago, Sobre o princípio da proporcionalidade. In: LEITE, George Salomão (Org.). Dos Princípios Constitucionais: Considerações em torno das normas principiológicas da Constituição. São Paulo: Malheiros, 2003, p. 249-252.

${ }^{349}$ Nesse sentido MENDONÇA, Andrey Borges de. Nova Reforma do Código de Processo Penal, p. 166.

${ }^{350}$ GRINOVER, Ada Pellegrini; FERNANDES, Antonio Scarance; GOMES FILHO, Antonio Magalhães. As Nulidades no Processo Penal, p. 145.

${ }^{351}$ ÁVILA, Thiago André Pierobom. Provas ilícitas e Proporcionalidade, p. 87.
} 
O direito à prova é composto pelos direitos à proposição da prova pelas partes, sua admissão pelo magistrado, pela produção probatória durante a instrução processual e pelo direito à valoração dos elementos de prova, quando da decisão judicial.

Conforme também já afirmado, pelo exercício do direito à prova é facultado às partes demonstrar a veracidade do quanto alegado. A busca da verdade implica a efetivação de Justiça, devendo ser, por isso, o direito à prova o mais amplo possível. Essa desejável amplitude probatória relaciona-se diretamente com a questão da admissibilidade de provas atípicas $^{352}$ no curso do processo.

Segundo Michele Taruffo "é prova tudo aquilo que sirva logicamente para provar o fato e não aquilo que a lei determina como prova". 353

Nesse sentido o artigo 332 do Código de Processo Civil prevê que: "todos os meios legais, bem como os moralmente legítimos, ainda que não especificados neste Código, são hábeis para provar a verdade dos fatos em que se funda a ação ou defesa".

O Código de Processo Penal Militar, por sua vez, traz regra semelhante no artigo 295 estabelecendo que: “é admissível, nos termos deste Código, qualquer espécie de prova, desde que não atente contra a moral, a saúde ou a segurança individual ou coletiva, ou contra a hierarquia ou a disciplina militares".

Embora o estatuto processual penal brasileiro não apresente uma disposição específica nesse sentido, o entendimento amplamente majoritário é o de que, também no âmbito processual penal vigora a liberdade probatória ${ }^{354}$, sendo admissíveis as provas que não sejam vedadas por regra expressa, incluídas aí as provas atípicas ${ }^{355}$.

\footnotetext{
${ }^{352}$ Ressalte-se que o tema será apenas mencionado por não ser objeto de estudo deste trabalho. Para uma análise detalhada vide DEZEM, Guilherme Madeira. Tipicidade processual e provas típicas e atípicas. 2008. $182 \mathrm{f}$. Dissertação (Mestrado em Direito) - Faculdade de Direito, Universidade de São Paulo, São Paulo, p. 95 ss. Segundo explana o autor provas atípicas são aquelas mencionadas pelo ordenamento jurídico mas que não tenham um procedimento específico estabelecido em lei, bem como aquelas provas que sequer são referidas pela legislação.

${ }^{353}$ TARUFFO, Michele. La prueba de los hechos, p. 406.

${ }^{354}$ Dentre outros, conforme BADARÓ, Gustavo Henrique Righi Ivahy. Provas típicas e provas anômalas: inadmissibilidade da substituição da prova testemunhal pela juntada de declarações escritas de quem poderia ser testemunha, p. 344 e GOMES FILHO, Antonio Magalhães. Notas sobre a terminologia da prova (reflexos no processo penal brasileiro), p. 315.

${ }^{355}$ DEZEM, Guilherme Madeira. Tipicidade processual e provas típicas e atípicas, p. 171. Conforme explana o autor as provas atípicas são aceitáveis no Brasil, pois a regra é a liberdade probatória, entretanto seu uso só será admitido caso não ocorra alguma das seguintes hipóteses limitativas: existir prova típica à disposição da parte; estar configurada alguma restrição à prova pela lei civil ou estar diante de uma regra de proibição de prova, como é o caso das provas ilícitas.
} 
Assim, a despeito da regra geral vigente em nosso ordenamento processual ser a da liberdade probatória, caso o elemento de prova seja obtido por meios ilícitos não será admitido nos autos do processo, não podendo influenciar na formação da convicção do magistrado da causa, por constituir-se em uma exceção à regra geral, imposta por expressa vedação constitucional. Portanto, a regra geral da liberdade probatória (decorrente do próprio direito ao contraditório e ao acesso à Justiça) não será aplicável no caso concreto pois que em confronto com outra regra, de natureza constitucional, e em sentido contrário.

Trata-se de clara adoção da regra do "tudo ou nada", não sendo aplicada a regra geral infraconstitucional por contrariar uma disposição especial e hierarquicamente superior, que a excepciona $^{356}$.

Portanto, conforme demonstrado, a norma que veda a admissão de elementos de prova obtidos por meios ilícitos nos autos do processo possui natureza jurídica de regra, e não de princípio.

De fato, ou as provas serão consideradas lícitas e serão plenamente admitidas no processo, ou, por outro lado serão consideradas ilícitas e não poderão ingressar nos autos. Assim, a norma do artigo $5^{\circ}$, inciso LVI, da Constituição Federal ou é aplicada ou não é, denotando sua natureza de regra.

É este também o entendimento de Humberto Ávila. O autor, aliás, assim se pronuncia sobre a questão especificamente: "A proibição de utilização de prova ilícita pode ser considerada um princípio? Claro que não". 357

Christian Sthefan Simons valendo-se de argumentação distinta obtém a mesma conclusão. Segundo o autor "a norma jurídica do art. 5, LVI da Constituição Federal tem natureza de regra, por não conter carga axiológica e determinar comportamento ao seu destinatário por meio de subsunção". ${ }^{358}$

\footnotetext{
${ }^{356}$ Em sentido contrário, sustentando ser a norma inserta no artigo $5^{\circ}$, inciso LVI, da Constituição Federal um princípio constitucional e não uma regra: ÁVILA, Thiago André Pierobom. Provas ilícitas e Proporcionalidade, p. 102-111. Afirma o autor expressamente nas páginas 103 e 104, tratando da "prova ilícita pro reo": "Ora, se nessas situações é admissível uma exceção ao disposto no art. $5^{\circ}$, LVI, da CF/88, pela necessidade de ponderação de interesses com outro vetor constitucional, não há dúvidas em afirmar que tal dispositivo configura um princípio, segundo a classificação de Alexy: o princípio da inadmissibilidade das provas obtidas por meios ilícitos. Ainda que a redação do dispositivo pareça apontar para sua configuração como uma regra (por estabelecer uma norma para o caso concreto), por trás da regra há o princípio, que justifica a criação da regra".

${ }_{357}$ ÁVILA, Humberto. Teoria dos Princípios: da definição à aplicação dos princípios jurídicos, p. 86 e 89.

${ }^{358}$ SIMONS, Christian Sthefan. A prova ilícita no direito processual penal norte-americano e alemão e as influências no processo penal brasileiro, p. 144.
} 
Aliás a opção do Constituinte de prever a norma que veda a admissibilidade de provas ilícitas no processo valendo-se de uma regra ${ }^{359}$ (que a princípio não admitiria exceções ${ }^{360}$ ) e inserindo-a no Título que trata dos direitos e garantias fundamentais (constituindo verdadeira cláusula pétrea ${ }^{361}$ ) pode ser explicada pelo contexto histórico que precedeu a promulgação da Constituição Federal. Essa opção do legislador constituinte visava conferir à norma inserta no artigo $5^{\circ}$, LVI da Constituição Federal maior rigidez formal e material $^{362}$. Pode ser compreendida como uma reação dos representantes do povo à vasta utilização de tortura, prisões ilegais e demais métodos espúrios de colheita de prova, durante os anos de ditadura no país ${ }^{363}$.

De todo modo cumpre notar que, conforme já mencionado, em que pese tratarse o artigo $5^{\circ}$, LVI da Constituição Federal de uma regra jurídica poder-se-á aplicar a proporcionalidade e o sopesamento de bens em casos concretos em que se verifique o choque de valores constitucionais com a vedação das provas ilícitas.

Isso poderá se dar ${ }^{364}$, em razão das especificidades do caso, seja porque se considere, como Robert Alexy, que a regra estará sempre embasada em um princípio que poderá ser sopesado no caso concreto ${ }^{365}$, ou ainda, nos limites já aduzidos no tópico anterior, com base no quanto exposto por Humberto Ávila ${ }^{366}$.

\footnotetext{
${ }^{359}$ Vale lembrar que segundo ÁVILA, Humberto. Teoria dos Princípios: da definição à aplicação dos princípios jurídicos, p. 114 ss, a superação das determinações impostas por meio de normas-regras tende a ser mais dificultosa do que a feita valendo-se de um princípio. Nesse sentido afirma o autor nas páginas 104 e 105: "As regras consistem em normas com pretensão de solucionar conflitos entre bens e interesses, por isso possuindo caráter 'prima facie' forte e superabilidade mais rígida (isto é, as razões geradas pelas regras, no confronto com razões contrárias, exigem um ônus argumentativo maior para serem superadas); os princípios consistem em normas com pretensão de complementariedade, por isso tendo caráter 'prima facie' fraco e superabilidade mais flexível (isto é, as razões geradas pelos princípios, no confronto com razões contrárias, exigem um ônus argumentativo menor para serem superadas)".

${ }^{360}$ Voltar-se-á ao tema no item 4.3.1. Convém, porém, deixar já assinalado que com a expressão "a princípio não admitiria exceções" se está a indicar que a Constituição Federal não traz, de per si, qualquer ressalva ao quanto estabelecido no artigo $5^{\circ}$, inciso LVI, o que, por outro lado, como também adiante será visto, não impede que a regra constitucional seja restringida pelo legislador infraconstitucional com vistas a compatibilizar direitos fundamentais contrapostos, desde que tal restrição seja constitucionalmente justificável.

${ }^{361}$ Conforme será visto em detalhes no item 4.3.1.

${ }^{362}$ Haja vista que a Constituição Federal possui um processo modificativo mais dificultoso do que as leis infraconstitucionais, quanto mais em se tratando de uma cláusula pétrea.

${ }^{363}$ Nesse sentido vide: SARLET, Ingo Wolfgang. A eficácia dos direitos fundamentais, p. 77 ss.

${ }^{364}$ Destaque-se que a tomada de posicionamento acerca do tema fugiria dos limites propostos no presente trabalho. O importante a destacar nesse ponto é que ambos os autores, Robert Alexy e Humberto Ávila, ainda que partindo de concepções teóricas distintas, admitem restrições a direitos fundamentais por meio de sopesamento e da proporcionalidade.

${ }^{365}$ Conforme SILVA, Virgílio Afonso da. Direitos Fundamentais: conteúdo essencial, restrições e eficácia. p. 58. O autor explica que, segundo a teoria dos princípios de Robert Alexy, nos casos de colisões entre uma regra e
} 
De acordo com o autor brasileiro, apesar de ser corrente a idéia de que a proporcionalidade só seria aplicável no caso de colisão de princípios, se no caso concreto ficar comprovado que a aplicação da regra conforme prevista no dispositivo normativo acabaria por

ferir a sua própria razão de existir, esta não deverá ser aplicada ${ }^{367}$. Trata-se de fazer a ponderação de direitos fundamentais em choque mesmo em face de uma regra constitucional, desde que verificada a imprescindibilidade de assim atuar com vistas a prestigiar a norma. É o que ocorre no caso da adoção da "prova ilícita pro reo", por exemplo.

\subsubsection{Classificação}

Seguindo na análise do artigo $5^{\circ}$, inciso LVI, da Constituição Federal é preciso notar que o mesmo dispositivo traz uma norma coercitiva, como não poderia deixar de ser, tendo em vista ser uma regra constitucional; e de caráter proibitivo, impondo uma abstenção, uma obrigação de não-fazer aos sujeitos do processo, independentemente da vontade das partes envolvidas $^{368}$.

Conforme clara opção do constituinte, o artigo $5^{\circ}$, inciso LVI, da Constituição Federal, inserto no capítulo que trata dos direitos e deveres individuais e coletivos, no título dos direitos e garantias fundamentais, configura um direito fundamental.

um princípio deverá na verdade se operar o sopesamento entre o "princípio em questão e o princípio que sustenta a regra que com ele colide". Nesse sentido vide também: ÁVILA, Thiago André Pierobom. Provas ilícitas $e$ Proporcionalidade, p. 103-104 e GUERRA FILHO, Willis Santiago. Sobre o princípio da proporcionalidade, p. 242.

366 ÁVILA, Humberto. Teoria dos Princípios da definição à aplicação dos princípios jurídicos, p. 58-59.

367 Nesse sentido também: BARROSO Luís Roberto; BARCELLOS Ana Paula de. A nova interpretação constitucional dos princípios. In: LEITE, George Salomão (Org.). Dos Princípios Constitucionais: Considerações em torno das normas principiológicas da Constituição. São Paulo: Malheiros, 2003, p. 114. Segundo os autores: "Mais recentemente já se discute tanto a aplicação do esquema tudo-ou-nada aos princípios como a possibilidade de também as regras serem ponderadas". Ainda de acordo com os mesmos autores, a ponderação de regras ocorrerá em situações em que uma regra, perfeitamente válida em abstrato, possa gerar uma inconstitucionalidade ao incidir em determinado ambiente, ou, ainda, em hipóteses em que a adoção do comportamento descrito pela regra viole gravemente o próprio fim a que ela busca alcançar.

${ }^{368}$ SILVA, José Afonso da. Aplicabilidade das normas constitucionais. 7. ed. São Paulo: Malheiros, 2008, p. 6771. 
Além disso, não há que se olvidar que o direito à inadmissibilidade das provas ilícitas encontra amparo no quanto previsto no artigo $60, \S 4^{\circ}$, inciso IV, da Constituição Federal, constituindo-se em uma cláusula pétrea ${ }^{369}$.

Assim no Brasil, diferentemente dos Estados Unidos, berço da teoria das regras de exclusão, a norma que determina a inadmissibilidade das provas ilícitas no processo tem como fundamentação precípua a proteção de direitos individuais ${ }^{370}$, constituindo-se ela própria também em um direito fundamental, possuindo, portanto, limitações formais e materiais à sua restrição.

Ademais, trata-se de uma norma constitucional apta a produzir seus efeitos essenciais desde a promulgação da Constituição Federal, não sendo necessária a complementação de seu sentido por regramento infraconstitucional para que fosse aplicada.

Nesse sentido aproxima-se, em parte, das normas com eficácia plena e aplicabilidade direta, imediata e integral, segundo classificação de José Afonso da Silva ${ }^{371}$.

Conforme explana o autor, o termo eficácia pode ser tomado em dois sentidos: eficácia jurídica e eficácia social.

A eficácia social refere-se a verificabilidade de atuações e condutas humanas conforme a norma. Isto é, diz respeito a própria constatação de que a norma jurídica é obedecida e respeitada por seus destinatários.

Já a eficácia jurídica "diz respeito à aplicabilidade, exigibilidade ou executoriedade da norma, como possibilidade de sua aplicação jurídica. $O$ alcance dos objetivos da norma constitui a efetividade". ${ }^{372}$

\footnotetext{
${ }^{369}$ SARLET, Ingo Wolfgang. A eficácia dos direitos fundamentais, p. 88-89.

${ }^{370}$ Para as diferentes finalidades concebidas às regras de vedação probatória vide: GUARIGLIA, Fabricio. Concepto, fin y alcance de las prohibiciones de valoración probatoria en el procedimiento penal: Uma propuesta de fundamentación, p. 37 ss. No Brasil a inadmissibilidade das provas ilícitas além de proteger os direitos individuais configura-se ela própria em um direito fundamental. Isso não significa, entretanto, que no caso concreto não possam surgir outras funcionalidades para a exclusão da prova ilícita para além da proteção dos direitos fundamentais.

${ }^{371}$ Segundo o autor as normas constitucionais quanto à sua eficácia podem ser classificadas em normas de eficácia plena (que seriam aquelas capazes de produzir todos os seus efeitos essenciais diretamente e de imediato, desde a promulgação da Constituição Federal), normas de eficácia contida (consideradas com eficácia plena, mas podendo ser objeto de restrições pelo legislador infraconstitucional) e normas de eficácia limitada (cuja produção plena de efeitos dependeria da atuação estatal). Para mais informações acerca dessa classificação vide: SILVA, José Afonso da. Aplicabilidade das normas constitucionais, p. 83 ss.

${ }^{372}$ SILVA, José Afonso da. Aplicabilidade das normas constitucionais, p. 66.
} 
O autor adota o termo em sua acepção jurídica, possuindo eficácia plena e aplicabilidade direta, imediata e integral a norma que contiver todos os elementos necessários para a sua incidência direta, não necessitando de outra norma integradora.

Conforme preleciona José Afonso da Silva: "Todas as normas regulam certos interesses em relação a determinada matéria. Não se trata de regular a matéria em si, mas de definir situações, comportamentos ou interesses vinculados a determinada matéria". ${ }^{373}$ Assim, segundo o autor, quando a regulamentação normativa for tal que se possa saber, de antemão e com precisão, que conduta deve ser seguida em relação ao tema regrado, a norma estará completa e juridicamente dotada de plena eficácia, ainda que, eventualmente, não seja socialmente eficaz. Nas palavras do referido constitucionalista: "Isso se reconhece pela própria linguagem do texto, porque a norma de eficácia plena dispõe peremptoriamente sobre os interesses regulados". 374

Afirma ainda o autor serem as normas constitucionais de eficácia plena e aplicabilidade direta, imediata e integral aquelas "a que o legislador constituinte deu formulação suficiente para reger as condutas, comportamentos e situações nelas cogitadas, geradoras, por isso, de situações subjetivas de vantagem ou desvantagem, desde a entrada da constituição em vigor". 375

Ademais, sustenta serem de eficácia plena, em regra, as normas constitucionais que contenham vedações ou proibições, como é o caso da norma inserta no artigo $5^{\circ}$, inciso LVI, da Constituição Federal ${ }^{376}$.

Contudo, apesar das semelhanças iniciais é imperioso notar que a referida regra constitucional acaba por se distanciar da aludida classificação doutrinária. Isso porque segundo José Afonso da Silva as normas de eficácia plena, diferentemente das normas de eficácia contida, não seriam passíveis de restrições por leis infraconstitucionais ${ }^{377}$ e, conforme será visto adiante, sustenta-se nesse trabalho a restringibilidade de qualquer direito

\footnotetext{
${ }^{373}$ SILVA, José Afonso da. Aplicabilidade das normas constitucionais, p. 99.

${ }^{374}$ SILVA, José Afonso da. Aplicabilidade das normas constitucionais, p. 99.

${ }^{375}$ SILVA, José Afonso da. Aplicabilidade das normas constitucionais, p. 226-227.

${ }^{376}$ SILVA, José Afonso da. Aplicabilidade das normas constitucionais, p. 101.

${ }^{377}$ Para mais detalhes acerca dessa abordagem crítica da classificação de José Afonso da Silva quanto à eficácia das normas constitucionais vide: SILVA, Virgílio Afonso da. Direitos Fundamentais: conteúdo essencial, restrições e eficácia, p. 223 ss.
} 
fundamental, desde que de forma constitucionalmente justificável (proporcional) e com o objetivo de compatibilizar direitos.

De qualquer modo, vale constatar que a Constituição Federal não conceitua como de fato não deveria fazê-lo - o que são "provas obtidas por meios ilícitos" ou simplesmente "provas ilícitas".

Como é cediço, a Constituição de um país deve tratar dos temas fundantes do Estado, ou seja, deve trazer em seu bojo os elementos integrantes e constitutivos do Estado ${ }^{378}$, a saber: soberania, finalidade, povo e território ${ }^{379}$.

Ainda que se trate de uma Constituição analítica, ou prolixa ${ }^{380}$, como a Constituição brasileira, não parece adequado que a Lei Maior de um país introduza conceitos e definições normativas. Tanto mais no caso da Constituição da República Federativa do Brasil, haja vista tratar-se de uma Constituição rígida ${ }^{381}$, ou seja, uma Constituição que possui um processo legislativo mais árduo e dificultoso para sua alteração do que as demais leis infraconstitucionais.

De fato, a Constituição Federal não é a sede adequada para a previsão de conceitos jurídicos, tais como a definição do que seriam provas ilícitas.

Ademais, como já mencionado, a despeito de inexistir regulamentação legislativa para o tema até meados de 2008, quando entrou em vigor a Lei $\mathrm{n}^{\circ} 11.690 / 08$, a falta de definição legal para o que seria considerado como prova ilícita nunca se constituiu em óbice para a aplicação do dispositivo constitucional pelos tribunais brasileiros ${ }^{382}$.

378 DALLARI, Dalmo de Abreu. Elementos da teoria geral do Estado. 25. ed. São Paulo: Saraiva, 2005, p. 119. $\mathrm{O}$ autor conceitua Estado como "a ordem jurídica soberana que tem por fim o bem comum de um povo situado em determinado território".

${ }^{379}$ Conforme LENZA, Pedro. Direito Constitucional Esquematizado. 12. ed. rev. atual. e ampl. São Paulo: Editora Saraiva, 2008, p. 21.

380 Conforme BONAVIDES, Paulo. Curso de Direito Constitucional, p. 91: “As Constituições prolixas (...) são em geral aquelas que trazem matéria por sua natureza alheia ao direito constitucional propriamente dito. Trata-se ora de minúcias de regulamentação, que melhor caberiam em leis complementares, ora de regras ou preceitos até então reputados pertencentes ao campo da legislação ordinária e não do Direito Constitucional, em cuja esfera entram apenas formalmente, por arbítrio do legislador constituinte, para auferir garantias que só a Constituição proporciona em toda a amplitude".

381 Para mais detalhes acerca das classificações constitucionais vide LENZA, Pedro. Direito Constitucional Esquematizado, p. 22-29

${ }^{382}$ No mesmo sentido: GOMES FILHO, Antonio Magalhães. Provas Lei 11.690, de 09.06.2008, p. 262-265. Em sentido diverso, MENDONÇA, Andrey Borges de. Nova Reforma do Código de Processo Penal, p. 164. Afirma este autor, fazendo menção à Exposição de Motivos do Anteprojeto: "Veio em boa hora a disciplina legal, pois é relevante que a lei processual penal fize as balizas da regra constitucional de exclusão das provas ilícitas". 
Assim, pode-se afirmar que o artigo $5^{\circ}$, inciso LVI, da CF encontra-se apto a produzir seus efeitos, independentemente de qualquer norma integrativa, desde a promulgação da Constituição Federal em $1988^{383}$.

De fato, a fim de explicitar o que seriam consideradas como provas obtidas por meios ilícitos, os Tribunais valiam-se do conceito doutrinário majoritariamente aceito, desenvolvido por Pietro Nuvolone e difundido internamente por Ada Pellegrini Grinover ${ }^{384}$.

Ou seja, embora o artigo $5^{\circ}$, inciso LVI, da Constituição Federal tivesse condições de ser aplicado e irradiar seus principais efeitos desde a promulgação da atual Constituição, pois dotado dos meios e elementos necessários à sua executoriedade, o legislador ordinário entendeu ser conveniente trazer para o ordenamento jurídico brasileiro, anos mais tarde, um conceito legal para "provas ilícitas".

\subsubsection{Alcance}

Como é cediço, o artigo $5^{\circ}$, inciso LVI da Constituição Federal veda a utilização de provas obtidas por meios ilícitos em qualquer processo que tenha curso no Brasil.

Conforme preconizam Ada, Scarance e Magalhães, "prova” na acepção estrita do termo deve ser entendida como sendo apenas aquela produzida em juízo e sob o crivo do contraditório $^{385}$.

Assim, qualquer outro elemento que venha a ser produzido em um âmbito diferente do processo judicial como, por exemplo, no inquérito policial, deve ser entendido como sendo um elemento informativo, ou de convicção, mas não probatório ${ }^{386}$. Ressalte-se

\footnotetext{
${ }^{383} \mathrm{O}$ que não impede, como afirmado anteriormente, que tal norma viesse a ser regulamentada por lei. A respeito do tema, criticando a opção do legislador infraconstitucional, FEITOZA, Denilson. Reforma Processual Penal: uma abordagem sistêmica. Niterói: Editora Impetus, 2008, p. 191: “A Constituição não define provas ilícitas em seu art. $5^{\circ}$, LVI. Por conseguinte, o sentido constitucional pode ser mais restritivo do que o do novo art. 157 do CPP".

${ }^{384}$ Como já salientado, segundo esses autores provas ilícitas seriam aquelas obtidas em ofensa a direitos materiais. Conforme explanado também no item 1.3.3, modernamente tal conceito tem sofrido uma releitura para indicar as provas ilícitas como aquelas obtidas em violação a direitos fundamentais.

385 GRINOVER, Ada Pellegrini; FERNANDES, Antonio Scarance; GOMES FILHO, Antonio Magalhães. As Nulidades no Processo Penal, p. 145-148.

386 JÚNIOR, Aury Lopes. Direito Processual Penal e sua Conformidade Constitucional. v. II, p. 534.
} 
que tal diferenciação agora é feita de forma expressa no texto legal a partir da nova redação conferida ao artigo 155 do Código de Processo Penal, após a entrada em vigor da Lei $\mathrm{n}^{\circ}$ 11.690/08, em agosto daquele ano.

Entretanto há que se ressaltar que a vedação constitucional contida no artigo $5^{\circ}$, inciso LVI, da Constituição Federal parece também abranger os chamados "elementos informativos".

De fato, como já afirmado, a ilicitude da prova advém de sua obtenção (e não de sua produção), a qual se dá, via de regra, em um momento extraprocessual. Assim, parece estarem abrangidos na garantia do artigo $5^{\circ}$, inciso LVI, da Constituição Federal também os elementos de informação.

Outrossim, seria absurdo pensar que uma confissão obtida mediante tortura não seria aceita no processo judicial como meio de prova, mas poderia instruir os autos de um inquérito policial a embasar a propositura de uma ação penal.

Portanto, conclui-se que o artigo 5, inciso LVI, da CF utiliza o termo "provas" no sentido de "fonte de prova" (e não "meio de prova"), vindo de fato, a coibir tais ilicitudes em qualquer tipo de processo que tenha curso no Brasil e também nos inquéritos policiais.

Nesse ponto, é preciso atentar que o termo "processo" utilizado pelo artigo 50, inciso LVI da Constituição Federal para se mostrar realmente efetivo no ordenamento jurídico pátrio não deve ser restrito ao processo judicial, mas compreendido de uma maneira mais abrangente, englobando também a vedação de provas obtidas por meios ilícitos nos processos administrativos, bem como coibindo fontes de prova viciadas com a mácula da ilicitude também nos autos de inquéritos policiais ${ }^{387}$.

Em relação aos processos administrativos há inclusive previsão legal nesse sentido, conforme consta do artigo 30 da Lei $\mathrm{n}^{\mathrm{o}} 9.784 / 99^{388}$, que regula o processo administrativo no âmbito da Administração Pública Federal.

Já no que tange ao inquérito policial, em que pese não ser este considerado um processo- mas um procedimento investigativo informativo, de natureza sigilosa, conforme a

\footnotetext{
${ }^{387}$ Concordando com a abrangência do dispositivo constitucional sobre o processo administrativo, mas negando a influência sobre o inquérito penal vide: PRADO, Leandro Cadenas. Provas ilícitas: Teoria e interpretação dos Tribunais Superiores, p. 23. Assim afirma o autor: "Ressalte-se que o alcance dessa proibição abrange tanto o processo judicial, como o administrativo. Não engloba, por outro lado, o inquérito".

${ }^{388}$ Art. 30 da Lei 9.784/99: "São inadmissíveis no processo administrativo as provas obtidas por meios ilícitos".
} 
doutrina dominante ${ }^{389}$-, certo é que os direitos fundamentais dos sujeitos investigados devem ser, também nessa seara, estritamente observados.

Assim, infrações aos direitos fundamentais dos indivíduos também aí não poderão, de maneira alguma, ser toleradas. Nesse sentido é que se afirma que a regra inserta no artigo $5^{\circ}$, inciso LVI da Constituição Federal abarca também o âmbito da investigação criminal para vedar, de forma peremptória, a adoção de práticas ilícitas para a obtenção de elementos de convicção e fontes de prova a embasar a propositura da ação penal ${ }^{390}$.

É nesse sentido também o posicionamento de Marcelo Lopes Barroso. Segundo o autor "caso o Ministério Público ofereça a denúncia lastreada exclusivamente em provas ilícitas, cabe ao juiz rejeitá-la por falta de justa causa". 391

Ressalte-se, por oportuno, ser indiferente no ordenamento processual brasileiro a inquirição de quem praticou a ilicitude na colheita da prova: se particulares ou agentes policiais, a fim de determinar a inadmissibilidade ou não do elemento de prova nos autos ${ }^{392}$.

Verificada a ilegalidade na obtenção da fonte de prova deverá esta ser considerada ilícita e inadmissível nos autos o referido meio de prova, independentemente de quem cometeu a ilicitude, se integrante das forças de segurança ou não.

De fato, como já salientado, a regra que veda a inadmissibilidade das provas obtidas por meios ilícitos nos autos do processo tem sede constitucional, existindo para melhor tutelar os direitos fundamentais dos indivíduos. Assim, diferentemente do que ocorre nos EUA ou na Alemanha, por exemplo, irrelevante será a apuração da qualidade do infrator para determinar a inadmissibilidade do referido elemento de prova nos autos.

\footnotetext{
${ }^{389}$ Dentre outros vide: MIRABETE, Julio Fabbrini. Código de Processo Penal Interpretado. 11. ed. São Paulo: Editora Atlas, 2008, p. 86.

${ }^{390}$ No mesmo sentido vide: GIACOMOLLI, Nereu José. Reformas do Processo Penal: Consideraçães críticas. Rio de Janeiro: Editora Lumen Juris, 2008, p. 50. O autor afirma "a prova declarada ilícita não poderá integrar nenhum processo, isto é não poderá ingressar em nenhum procedimento ou processo (procedimento em contraditório) e, uma vez neles inserida deverá ser desentranhada e destruída. Com essa determinação legal, a prova ilícita não poderá servir nem como notitia criminis".

${ }^{391}$ BARROSO, Marcelo Lopes. Reformas no Processo Penal, p. 100.

392 SILVA, Bruno César Gonçalves da. Da prova ilicitamente obtida por particular no Processo Penal. Campinas: Editora Servanda, 2010, p. 97-111.
} 


\subsection{Disciplina legal das provas ilícitas no Código de Processo Penal}

As provas ilícitas têm seu regramento infraconstitucional ditado pelo artigo 157 do Código de Processo Penal ${ }^{393}$.

As provas ilícitas originárias vêm dispostas no caput do artigo 157 do CPP, em sua nova redação.

O parágrafo terceiro do referido dispositivo trata das provas ilícitas em geral, estabelecendo o incidente para o desentranhamento da prova declarada inadmissível.

Além desses, o Projeto de Lei $\mathrm{n}^{\circ}$ 4.205/01 previa ainda um quarto parágrafo para o artigo 157 do CPP, o qual pretendia impedir que o juiz que tomasse contato com a prova ilícita pudesse proferir a sentença ou acórdão. Entretanto tal disposição normativa acabou sendo vetada pelo Chefe do Poder Executivo.

O regramento normativo da prova ilícita por derivação fica a cargo dos parágrafos $1^{\circ} \mathrm{e} 2^{\circ}$ do mesmo dispositivo legal.

Assim, serão abordadas as previsões normativas infraconstitucionais que tratam da prova ilícita originária e da prova ilícita em geral, bem como a disposição proposta sobre o tema no Projeto de Novo Código de Processo Penal, para então tratar em detalhes da prova ilícita por derivação, no próximo capítulo.

\footnotetext{
393 “Art. 157. São inadmissíveis, devendo ser desentranhadas do processo, as provas ilícitas, assim entendidas as obtidas em violação a normas constitucionais ou legais.

$\S 1^{\circ}$ São também inadmissíveis as provas derivadas das ilícitas, salvo quando não evidenciado o nexo de causalidade entre umas e outras, ou quando as derivadas puderem ser obtidas por uma fonte independente das primeiras.

$\S 2^{\circ}$ Considera-se fonte independente aquela que por si só, seguindo os trâmites típicos e de praxe, próprios da investigação ou instrução criminal, seria capaz de conduzir ao fato objeto da prova.

$\S 3^{\circ}$ Preclusa a decisão de desentranhamento da prova declarada inadmissível, esta será inutilizada por decisão judicial, facultado às partes acompanhar o incidente."
} 


\subsubsection{Definição legal e interpretação}

Conforme já salientado, a Lei no 11.690/08, entrou em vigor em 10 de agosto de 2008, conferindo nova redação ao artigo 157, caput, do Código de Processo Penal vigente.

$\mathrm{O}$ referido dispositivo trouxe para o CPP um conceito legal para provas ilícitas, como sendo aquelas que "são obtidas em violação a normas constitucionais ou legais" pouco importando se tais normas tutelam direitos fundamentais ou quaisquer outros, ou se são normas de natureza material ou não.

De acordo com essa definição legal há quem sustente que a afronta a uma norma legal (infraconstitucional) de natureza processual em matéria probatória passaria a ser considerada como prova ilícita ${ }^{394}$.

É o entendimento de Nereu José Giacomolli, segundo o qual: “a inadmissibilidade ultrapassa a violação constitucional (direitos fundamentais, garantias constitucionais) para alcançar, também, a violação das regras processuais". 395

Guilherme de Souza Nucci afirma também de forma peremptória: "defendemos, lastreados no disposto no art. 157, caput, do CPP, serem ilícitas todas as provas obtidas com violação a normas constitucionais ou legais (normas penais ou processuais penais)". 396

Entretanto tal interpretação gramatical não pode ser sustentada, pois acabaria por desestruturar por completo a lógica que rege o Código de Processo Penal brasileiro, extinguindo o regime de nulidade das provas produzidas com irregularidades processuais, para igualá-las às provas ilícitas, que são inadmissíveis no processo.

${ }^{394}$ Conforme preconiza, dentre outros, GOMES, Luiz Flávio. Lei 11.690/2008 e provas ilícitas: conceito e admissibilidade. Disponível em: 〈http://www.lfg.com.br〉. Acesso em: 20 jun. 2008. Afirma o autor: "Dizia-se que a CF, no art. $5^{\circ}, \mathrm{LVI}$, somente seria aplicável às provas ilícitas ou ilícitas e ilegítimas ao mesmo tempo, ou seja não se aplicaria para as provas (exclusivamente) ilegítimas. Para esta última valeria o sistema da nulidade, enquanto para as primeiras vigoraria o sistema da inadmissibilidade. Ambas as provas, em princípio, não valem, mas os sistemas seriam distintos. Essa doutrina já não pode ser acolhida. Quando o art. 157 fala em violação a normas constitucionais ou legais, não distingue se a norma legal é material ou processual". Assim, na visão exarada pelo autor logo após a alteração legislativa, qualquer violação ao devido processo legal conduziria à ilicitude da prova.

${ }^{395}$ GIACOMOLLI, Nereu José. Reformas do Processo Penal: Considerações críticas, p. 38.

${ }^{396}$ NUCCI, Guilherme de Souza. Provas no Processo Penal, p. 31. 
Ora, certo é que não foi essa a intenção dos legisladores quando aprovaram a alteração de redação do dispositivo, eis que falta racionalidade jurídica e fundamentação teórica em tal proposição.

Antonio Magalhães Gomes Filho critica a nova redação do caput do artigo 157 sustentando não ter sido a melhor a opção do legislador nacional por uma definição legal de prova ilícita, que, ao invés de esclarecer o sentido da previsão constitucional, termina por levar a equívocos, podendo fazer crer, por exemplo, que a violação de regras processuais implicaria ilicitude da prova ${ }^{397}$.

Para Antonio Scarance Fernandes, a despeito da má redação legal o caput do artigo 157 do CPP há que ser interpretado fazendo-se a identificação de provas ilícitas com àquelas obtidas em violação a normas constitucionais ou legais de cunho material. A propósito afirma que se deve "entender como normas legais apenas as de natureza material, precipuamente as que definem as infrações penais". 398

Aury Lopes Júnior posiciona-se no mesmo sentido, defendendo a manutenção da clássica distinção doutrinária entre provas ilícitas e ilegítimas, apesar da redação conferida ao caput do artigo 157 do Código de Processo Penal. Assim, o autor identifica as provas ilícitas com àquelas obtidas em desconformidade com a Constituição Federal ou com leis materiais $^{399}$.

É esse também o entendimento de Sérgio Ricardo de Souza. Afirma o autor: "Ao que parece a parte final do novo dispositivo se refere às normas legais de natureza material e não, àquelas puramente processuais, sujeitas estas às regras das nulidades insertas no Livro III, Título II do CPP, conforme doutrina de Pietro Nuvolone, majoritariamente acolhida pela doutrina brasileira". 400

Também para Marcelo Lopes Barroso a nova redação conferida ao artigo 157 do Código de Processo Penal não alterou a classificação doutrinária prevalente no Brasil entre provas ilícitas e provas ilegítimas ${ }^{401}$.

\footnotetext{
${ }^{397}$ GOMES FILHO, Antonio Magalhães. Provas Lei 11.690, de 09.06.2008, p. 266.

${ }^{398}$ FERNANDES, Antonio Scarance. Processo Penal Constitucional, p. 86.

399 JÚNIOR, Aury Lopes. Direito Processual Penal e sua Conformidade Constitucional. v. I, p. 581-582.

${ }^{400}$ SOUZA, Sérgio Ricardo de. Manual da Prova Penal Constitucional: Pós Reforma de 2008 atualizado de acordo com as Leis 11.689/08 e 11.690/08, p. 40.

${ }^{401}$ BARROSO, Marcelo Lopes. Reformas no Processo Penal, p. 101-102.
} 
Acerca do tema Andrey Borges de Mendonça sustenta que "a alteração não foi tão substancial quanto poderia parecer em uma primeira leitura". ${ }^{402}$ Conforme explana o autor a ilicitude da prova estará caracterizada por sua obtenção em violação a uma norma, seja legal ou constitucional. Já se a violação for praticada quando da introdução do elemento de prova no processo estará configurada a ilegitimidade, sujeita ao regime da nulidade do ato.

Denilson Feitoza, por sua vez, fazendo uma interpretação declarativa do artigo 157 do Código, sustenta que, segundo a nova redação legal, provas ilícitas são as que violam normas constitucionais de direito material ou processual, bem como as que violam normas legais infraconstitucionais de direito material. Por outro lado, provas ilegítimas são aquelas praticadas com infringência a normas legais de direito infraconstitucional processual ${ }^{403}$.

Assim, com base na nova redação do artigo 157 do Código, o referido autor acrescenta à definiçãa clássica de Nuvolone para provas ilícitas também as provas obtidas em ofensa a direitos constitucionais, quer de caráter material ou processual ${ }^{404}$.

Portanto, como é de se perceber, a Lei nº 11.690/08 modificativa do Código de Processo Penal acabou por não seguir a doutrina predominante, fazendo com que a temática da prova ilícita ganhasse ainda mais relevância no país, após a inserção em lei de um conceito elaborado sem boa técnica.

Fato é que a redação atual do caput do artigo 157 do Código de Processo Penal demanda do exegeta um considerável esforço interpretativo.

Como é sabido, a atividade de interpretação exige do aplicador da lei a interpretação dos fatos tanto quanto dos textos normativos, a fim de apreender o significado e alcance da norma jurídica.

Em verdade, a atividade de interpretação, para além de meramente declaratória, implica uma atividade constitutiva ${ }^{405}$. A partir da análise do fato e do texto normativo, da apreensão da norma jurídica, seu significado e alcance e da subsunção do fato à norma escolhida, dentre outras eventualmente cabíveis, aplica-se o direito.

\footnotetext{
402 MENDONÇA, Andrey Borges de. Nova Reforma do Código de Processo Penal, p. 165-166.

${ }^{403}$ FEITOZA, Denilson. Reforma Processual Penal: uma abordagem sistêmica, p. 191.

${ }^{404}$ No mesmo sentido, sustentando que provas obtidas em ofensa a regras processuais de índole constitucional constituem provas ilícitas: BARROS, Flaviane de Magalhães. (Re)forma do Processo Penal: Comentários críticos dos artigos modificados pelas Leis n. 11.690/08, n. 11.719/08 e n. 11.900/09, p. 40-41.

${ }^{405}$ GRAU, Eros Roberto. Ensaio e discurso sobre a interpretação/aplicação do direito, p. 27.
} 
Interpretação e aplicação do direito mostram-se como duas facetas de uma mesma operação lógica. Dito de outra forma, interpretar significa tornar concreta a lei, ou seja, aplicar o direito ao caso ${ }^{406}$.

Nos dizeres de Eros Roberto Grau a interpretação/aplicação "parte da compreensão dos textos normativos e dos fatos, passa pela produção das normas que devem ser ponderadas para a solução do caso e finda com a escolha de uma determinada solução para ele, consignada na norma de decisão". 407

Por certo, não é objeto do presente trabalho fazer um estudo aprofundado sobre hermenêutica e interpretação jurídica. Porém não se pode deixar de abordar resumidamente os métodos de interpretação clássicos referidos pela doutrina, de modo a subsidiar a interpretação dos dispositivos legais que tratam das provas ilícitas no sistema processual penal brasileiro.

A norma jurídica pode ser interpretada, com a utilização e combinação dos seguintes métodos: gramatical, lógico, histórico e sistemático, dentre outros ${ }^{408}$ apontados pela doutrina moderna.

Como é cediço, a interpretação gramatical pretende fazer o exame de significado e alcance de cada uma das palavras que compõem o preceito normativo ${ }^{409}$.

A interpretação histórica, por sua vez, tem como finalidade a reconstrução do momento e das condições presentes quando da edição da norma, com vistas a clarear a real intenção do legislador ao editar a lei.

Conforme explana Limongi França: "A interpretação lógica é aquela que se leva a efeito mediante a perquirição do sentido das diversas locuções e orações do texto legal, bem assim através do estabelecimento da conexão entre os mesmos"410.

A interpretação sistemática consiste em atribuir a melhor significação, dentre as várias possíveis, às normas objeto de interpretação, hierarquizando-as em um todo aberto composto pelo ordenamento jurídico, fixando-lhes o alcance e superando antinomias, buscando solucionar os conflitos verificados nos casos concretos. Em outras palavras, a

\footnotetext{
${ }^{406}$ GRAU, Eros Roberto. Ensaio e discurso sobre a interpretaçãolaplicação do direito, p. 35.

${ }^{407}$ GRAU, Eros Roberto. Ensaio e discurso sobre a interpretação/aplicação do direito, p. 27.

408 Criticando a utilização dos tradicionais métodos de interpretação vide: GRAU, Eros Roberto, Ensaio $e$ discurso sobre a interpretação/aplicação do direito, p. 43. Afirma, entretanto o autor que a interpretação deverá, ao menos, se deitar sob algumas pautas hermenêuticas, quais sejam: a interpretação do direito em seu todo, a finalidade do direito e os princípios.

${ }^{409}$ FRANÇA, R. Limongi. Hermenêutica Jurídica. 10. ed. rev. São Paulo: Editora dos Tribunais, 2010 , p. 23.

${ }^{410}$ FRANÇA, R. Limongi. Hermenêutica Jurídica, p. 24.
} 
interpretação sistemática é aquela que se realiza em consonância com a rede hierarquizada de normas, em especial respeitando a Lei Maior do país, consubstanciada em sua Constituição. Ao se aplicar uma norma, está-se aplicando, em verdade, o sistema inteiro ${ }^{411}$.

Assim, combinando os métodos acima referidos, especialmente os métodos histórico, lógico e sistemático e buscando interpretar o quanto previsto no caput do artigo 157 do CPP, de um lado, com vistas a evitar a confusão e distorção que a interpretação meramente gramatical pode gerar, ao pretender igualar a sistemática da inadmissibilidade das provas ilícitas à nulidade das provas ilegítimas e, de outro, alinhando-se à posição mais atual, que identifica as provas ilícitas com àquelas que ofendam normas de direitos fundamentais e não meramente materiais $^{412}$ propõe-se a seguinte interpretação para o referido dispositivo legal: "são provas ilícitas àquelas obtidas em ofensa a direitos fundamentais, notadamente com a prática de condutas tipificadas como crimes pela legislação penal”.

Em outras palavras, a previsão legal que estabelece serem "provas ilícitas as obtidas em violação a normas constitucionais ou legais" deve ser traduzida como sendo provas ilícitas aquelas que sejam obtidas com infração de direitos fundamentais, particularmente com a adoção, pelo sujeito infrator, de condutas que sejam tipificadas pela legislação penal.

É que, como já mencionado, não foi intenção da Comissão de juristas constituída para propor alterações ao CPP igualar a sistemática das nulidades das provas ilegítimas à inadmissibilidade das provas ilícitas.

De fato, a partir de uma análise histórica, já efetuada no presente trabalho, bem como a partir de uma análise de racionalidade legislativa e do sistema como um todo é possível afirmar que a referida Comissão nunca pretendeu inserir no conceito de prova ilícita àquelas produzidas com infrações às normas processuais, que devem, portanto, continuar sendo classificadas como provas ilegítimas.

Em verdade, não era intenção do legislador extinguir ou mesmo desestruturar o sistema de nulidades previsto no Código de Processo Penal, ou de outro modo tal alteração teria sido realizada com a revogação expressa dos referidos dispositivos, ou ao menos a partir da menção a essa intenção de revogação tácita na Exposição de Motivos da lei modificadora do Código.

${ }^{411}$ FREITAS, Juarez. A interpretação sistemática do direito. 2. ed. rev. e ampl. São Paulo: Malheiros, 1998, p. 60-61.

${ }^{412}$ Conforme destacado no subitem 1.3.3 do trabalho. 
Por outro lado, conforme se depreende do Anteprojeto de reforma do CPP, a referida Comissão de juristas pretendia que apenas fossem consideradas como ilícitas as normas obtidas em violação a "princípios ou normas constitucionais", ou seja àquelas que ofendessem os bens jurídicos mais caros aos indivíduos. Em outras palavras aquelas que ofendessem direitos fundamentais.

Isso porque o escopo principal do artigo $5^{\circ}$, inciso LVI da Constituição Federal é o de tutelar os direitos fundamentais, coibindo atuações de particulares e agentes estatais que os infrinjam na busca desenfreada por colheita de provas.

A tal conclusão chega-se também mediante uma análise lógica dos dispositivos insertos no artigo $5^{\circ}$, inciso LVI da CF e artigo 157 do CPP, e uma análise sistemática, envolvendo todo o ordenamento.

Assim, não é possível sustentar a interpretação meramente gramatical feita do caput do artigo 157 do CPP, a pretender que sejam também consideradas ilícitas as provas produzidas com irregularidades processuais, que permanecem sendo provas ilegítimas.

\subsubsection{Desentranhamento e inutilização}

O parágrafo $3^{\circ}$ do artigo 157 do Código de Processo Penal brasileiro prevê que "preclusa a decisão de desentranhamento da prova declarada inadmissível, está será inutilizada por decisão judicial, facultado às partes acompanhar o incidente”.

Conforme se depreende da disposição legal, o magistrado analisando o elemento probatório inserto nos autos o declarará ilícito, quando for o caso, determinando seu desentranhamento. Contra essa decisão a parte insurgente poderá recorrer. Uma vez preclusa a decisão, o juiz determinará sua inutilização ${ }^{413}$.

Para melhor compreensão da regra em comento é necessário que algumas observações sejam feitas.

O aludido parágrafo não estabelece em que momento processual ocorrerá a preclusão acerca da decisão de desentranhamento da prova ilícita.

${ }^{413}$ NUCCI, Guilherme de Souza. Provas no Processo Penal, p. 37. 
De fato, a referida decisão há que estar sujeita a recurso, no caso de eventual inconformismo da parte. Entretanto a Lei $n^{\circ} 11.690 / 08$ não previu qualquer meio de impugnação cabível nesse caso.

A questão era resolvida por outro Anteprojeto elaborado pela mesma Comissão de Juristas e posteriormente convertido no Projeto de Lei $n^{\circ} 4.206 / 2001$. O referido Projeto previa que, contra a decisão que declarasse lícita ou ilícita a prova, caberia recurso de agravo $^{414}$. Ocorre que até o presente momento tal projeto não foi aprovado, deixando a questão aparentemente sem solução.

Assim, diante da lacuna legislativa verificada instaura-se a controvérsia acerca do meio de impugnação cabível.

Para Guilherme de Souza Nucci ${ }^{415}$, em se tratando de decisão com força de definitiva seria cabível o recurso de apelação. Já segundo Ivan Luís Marques da Silva ${ }^{416}$, deverá o acusado utilizar o habeas corpus e a acusação o mandado de segurança. De acordo com Andrey Borges de Mendonça ${ }^{417}$ deve ser aplicável por interpretação extensiva o recurso em sentido estrito, com base no quanto disposto no artigo 581, inciso XIII, do CPP. Segundo o mesmo autor, no caso da prova não ser considerada ilícita deverá ser impetrado habeas corpus.

Em vista das distintas posições que se desenham sobre o tema, entende-se salutar considerar que apenas ocorrerá a preclusão da decisão que determina o desentranhamento da prova ilícita com o trânsito em julgado da sentença final, condenatória ou não ${ }^{418}$.

Outro ponto a ser destacado em relação ao mesmo $\S 3^{\circ}$ do artigo 157 do CPP está na previsão legal de que a prova ilícita seja inutilizada.

O Projeto de Lei $n^{\circ} 4.205 / 2001$ previa que a prova declarada ilícita de forma definitiva, depois de esgotados os recursos cabíveis, deveria seguir para o arquivamento sigiloso em cartório.

\footnotetext{
${ }^{414}$ GOMES FILHO, Antonio Magalhães. Provas Lei 11.690, de 09.06.2008, p. 271.

415 Provas no Processo Penal, p. 37.

${ }^{416}$ SILVA, Ivan Luís Marques da. Reforma Processual Penal de 2008: Lei 11.719/2008 (Procedimentos Penais), Lei 11.690/2008 (Provas), Lei 11.689/2008 (Júri), Comentadas artigo por artigo. São Paulo: Editora Revista dos Tribunais, 2008, p. 67.

${ }^{417}$ Nova Reforma do Código de Processo Penal, p. 173.

${ }^{418}$ Nesse sentido GOMES FILHO, Antonio Magalhães. Provas Lei 11.690, de 09.06.2008, p. 271.
} 
Tal previsão constante daquela redação proposta, pretendia com isso, evitar a destruição de elementos de prova que poderiam ser considerados úteis em outros processos. Em outras palavras, a prova considerada ilícita poderia ser utilizada nos autos do processo em que eventualmente se apurasse a conduta típica praticada para obtenção daquela prova ilícita, no caso de terem sido praticados crimes para a obtenção da referida prova, como os crimes de tortura, violação de domicílio, interceptação telefônica ilegal, dentre outros. Se inutilizada a prova, restaria prejudicada a própria demonstração e comprovação do fato criminoso praticado para obtê-la ${ }^{419}$.

Aliás, a previsão contida no parágrafo único do artigo 164 do Projeto de Novo Código de Processo Penal, em trâmite no Congresso Nacional prevê também o arquivamento sigiloso da prova ilícita. Conforme sugerido, o referido dispositivo pretende que a prova declarada inadmissível seja desentranhada dos autos e arquivada sigilosamente em cartório.

Ademais, como bem lembra Antonio Magalhães Gomes Filho, "não se pode descartar, ainda, a hipótese de se usar uma prova ilícita pro reo em outro processo, como o da revisão criminal". 420

Logo, a despeito do mandamento legal no sentido da destruição da prova ilícita, parece evidente a necessidade de se compatibilizar essa disposição legal com a necessária manutenção sigilosa dos elementos desentranhados dos autos processuais, em determinados casos, não os destruindo.

Para Nereu José Giacomolli a prova ilícita deverá ser destruída em incidente próprio, não servindo sequer como notitia criminis. No caso de "prova ilícita pro reo", mediante pedido da defesa será possível decidir pela conservação da mesma ${ }^{421}$.

Andrey Borges de Mendonça sustenta também que, com base na razoabilidade, deverá o juiz deixar de destruir a prova no caso em que esta se constitua em prova da materialidade do crime praticado para obter dado elemento de prova, ou ainda no caso de "prova ilícita pro reo" ${ }^{422}$.

\footnotetext{
${ }^{419}$ GOMES FILHO, Antonio Magalhães. Provas Lei 11.690, de 09.06.2008, p. 270.

${ }^{420}$ GOMES FILHO, Antonio Magalhães. Provas Lei 11.690, de 09.06.2008, p. 270.

${ }^{421}$ GIACOMOLLI, Nereu José. Reformas do Processo Penal: Considerações críticas, p. 50.

${ }^{422}$ MENDONÇA, Andrey Borges de. Nova Reforma do Código de Processo Penal, p. 173-174.
} 
Ainda em relação à previsão legal disposta na parte final do $\S 3^{\circ}$, do artigo 157 , do CPP é preciso salientar que a faculdade conferida às partes de acompanhar o incidente de inutilização da prova ilícita deve ser compreendida à luz da garantia do contraditório judicial.

Antonio Magalhães Gomes Filho sustenta ser imprescindível a presença do órgão acusador, bem como do réu e de seu defensor em dada oportunidade diante da importância do ato e de seus possíveis efeitos ${ }^{423}$.

\subsubsection{Julgamento e imparcialidade}

É importante notar ainda que o Projeto de Lei n 4.205/01 previa um quarto parágrafo para o artigo 157 do CPP com a seguinte redação: “O juiz que conhecer do conteúdo da prova declarada inadmissível não poderá proferir a sentença ou acórdão”. Esse parágrafo acabou sendo vetado pelo Chefe do Poder Executivo sob a alegação de que tais alterações feririam a celeridade processual e a boa prestação jurisdicional.

Constou das razões de veto que: "O objetivo primordial da reforma processual penal consubstanciada, dentre outros, no presente projeto de lei, é imprimir celeridade e simplicidade ao desfecho do processo e assegurar a prestação jurisdicional em condições adequadas. O referido dispositivo vai de encontro a tal movimento, uma vez que pode causar transtornos razoáveis ao andamento processual ao obrigar que o juiz que fez toda a instrução processual deva ser, eventualmente substituído por um outro que nem sequer conhece o caso. Ademais, quando o processo não mais se encontra em primeira instância, a sua redistribuição não atende necessariamente ao que propõe o dispositivo, eis que mesmo que o Magistrado conhecedor da prova inadmissível seja afastado da relatoria da matéria, poderá ter que proferir seu voto em razão da obrigatoriedade da decisão coligada".

O parágrafo vetado visava garantir a imparcialidade do Magistrado que fosse julgar a causa, com vistas a evitar que suas razões de decidir pudessem ser, ainda que indiretamente, contaminadas pela prova ilícita indevidamente juntada aos autos ${ }^{424}$.

${ }^{423}$ GOMES FILHO, Antonio Magalhães. Provas Lei 11.690, de 09.06.2008, p. 271. No mesmo sentido NUCCI, Guilherme de Souza. Provas no Processo Penal, p. 37. 
Buscava-se com o dispositivo vetado evitar o contato físico entre o juiz competente para o julgamento da causa e a prova ilícita, sob a sustentação de que, tal prova poderia ser considerada pelo julgador em seu processo decisional, ou seja, em sua formação íntima de convicção, ainda que não constasse ao final da fundamentação da decisão. Assim a indicação de tais provas não estaria expressa no processo justificativo, mas indiretamente poderia ter tido influência desastrosa no processo mental decisório do Magistrado atuante no caso $^{425}$.

Por tais razões, o veto ao referido parágrafo tem sido criticado pela doutrina sob a alegação de que se deu preferência à celeridade processual e às questões práticas do Judiciário brasileiro em detrimento do mandamento constitucional inserto no artigo $5^{\circ}$, LVI, da Constituição da República ${ }^{426}$.

É imperioso observar, contudo, que existem também posições favoráveis ao veto $^{427}$, sustentando que a disposição, como proposta, não era viável, especialmente no que diz respeito ao julgamento realizado nos Tribunais.

Reinaldo Daniel Moreira ${ }^{428}$ coloca-se em uma posição intermediária. Critica o veto sustentando que, desse modo, o juiz poderá levar em consideração as informações

${ }^{424}$ Conforme TASSE, Adel El; MILÉO, Eduardo Zanoncini; PIASECKI, Patrícia Regina. O Novo Sistema de Provas no Processo Penal. Curitiba: Editora Juruá, 2008, p. 48. No mesmo sentido SILVA, Ivan Luís Marques da. Reforma Processual Penal de 2008: Lei 11.719/2008 (Procedimentos Penais), Lei 11.690/2008 (Provas), Lei 11.689/2008 (Júri), Comentadas artigo por artigo, p. 69.

${ }^{425}$ GOMES, Luiz Flávio. Prova ilícita: direito à exclusão dos autos do processo ("exclusionary rule"). Disponível em: 〈http://www.lfg.com.br/public_html/article.php?story20041008122122480p〉. Acesso em: 15 set. 2010.

${ }^{426}$ Nesse sentido vide: SILVA, Ivan Luís Marques da. Reforma Processual Penal de 2008: Lei 11.719/2008 (Procedimentos Penais), Lei 11.690/2008 (Provas), Lei 11.689/2008 (Júri), Comentadas artigo por artigo, p. 6970; BARROS, Flaviane de Magalhães. (Re)forma do Processo Penal: Comentários críticos dos artigos modificados pelas Leis n. 11.690/08, n. 11.719/08 e n. 11.900/09, p. 43 e JÚNIOR, Aury Lopes. Direito Processual Penal e sua Conformidade Constitucional. v. I, p. 596.

${ }^{427}$ MENDONÇA, Andrey Borges de. Nova Reforma do Código de Processo Penal, p. 174-175. A respeito do veto ao $\S 4^{\circ}$ do artigo 157 do CPP assim se manifesta o autor: "Entendemos que o dispositivo, tal qual fora redigido, traria problemas sérios à administração da Justiça e, por isto, concordamos com o veto. Veja que, pelo dispositivo vetado, se o juiz tivesse tomado conhecimento da prova ilícita e, desde logo, indeferisse a sua juntada, já estaria impedido de julgar. Da mesma forma, o problema se agravaria nos Tribunais: se um desembargador determinasse o desentranhamento da prova, ficaria também impedido de julgar? E, posteriormente, no STF, se algum Ministro tomasse conhecimento da prova ilícita, não poderia mais julgar?" No mesmo sentido SOUZA, Sérgio Ricardo de. Manual da Prova Penal: Pós Reforma de 2008 atualizado de acordo com as Leis 11.689/08 e 11.690/08, p. 39: "A disposição não era razoável e poderia causar graves transtornos aos julgamentos pelos Tribunais, quando estes, por exemplo, apreciassem em grau de recurso ou de habeas corpus questão relativa à prova ilícita, já que ficariam impedidos de julgar os recursos posteriores, quando anteriormente tivessem contato com aquele arremedo de prova." 
colhidas a partir da prova ilícita, ainda que não as invoque expressamente como razão de decidir, considerando nesse ponto, portanto, pertinente o afastamento do referido julgador da causa. Contudo, aventa também a possibilidade de que caso fosse mantida a proposta de redação mencionada, em certos casos a parte descontente pudesse propositalmente inserir no material probatório constante dos autos uma prova ilícita, para deliberadamente afastar o Magistrado do caso.

De fato, o desentranhamento da prova ilícita não se mostra como uma medida eficaz e suficiente contra a utilização daquele elemento na decisão judicial, ainda que de forma implícita. Por outro lado, a declaração de afastamento do julgador que teve contato com a prova ilícita, poderia, em alguns casos, criar grandes dificuldades ao próprio julgamento da causa.

De qualquer forma, entende-se que dificuldades práticas ou de logística do Poder Judiciário brasileiro não são óbices suficientes a justificar o veto ao referido dispositivo, eis que a garantia às partes da não utilização da prova ilícita na decisão judicial mostra-se muito mais relevante do que os referidos inconvenientes.

Em sendo assim, melhor seria a manutenção do dispositivo no Código, adotando-se no caso a mesma solução empregada para os demais situações de impedimento ou de suspeição judicial ${ }^{429}$.

\subsection{Projeto de Novo Código de Processo Penal e as provas ilícitas}

Conforme já salientado foi constituída em meados de 2008 nova Comissão de Juristas para elaboração de Anteprojeto de Reforma do Código de Processo Penal, visando à revogação do Código de 1941 e à aprovação de Novo Código de Processo Penal.

A referida Comissão realizou durante o curso de seus trabalhos 17 audiências públicas em várias capitais brasileiras, tendo o trabalho culminado na entrega do Anteprojeto

\footnotetext{
${ }^{428}$ MOREIRA, Reinaldo Daniel. A reforma do Código de Processo Penal e a nova disciplina legislativa da prova penal. Boletim do Instituto de Ciências Penais, Belo Horizonte, ano VII, n. 91, out. 2008, p. 6.

${ }^{429}$ Conforme disposto nos artigos 96 a 103 do Código de Processo Penal.
} 
do Novo Código de Processo Penal, posteriormente convertido no Projeto de Lei do Senado $\mathrm{n}^{\mathrm{o}}$ 156/2009, assinado pelo presidente da Casa, Senador José Sarney.

No que tange à problemática da prova ilícita, a Comissão, parece ter caminhado bem ao recuar em relação às inovações legais introduzidas no estatuto processual penal recentemente.

A redação sugerida ao dispositivo não contempla qualquer definição legal para o que sejam consideradas provas ilícitas, limitando-se a repetir a regra constitucional, afirmando serem inadmissíveis as provas obtidas por meios ilícitos.

Nesse ponto, ao reproduzir a disposição constitucional, a redação conferida ao caput do artigo 164 do PLS no 156/2009 torna-se de fato desnecessária. Contudo, em que pese não se mostre relevante a inserção proposta, certo é que ao menos não são cometidos os equívocos e confusões verificados na redação conferida ao artigo 157 do Código vigente.

É este também o entendimento de Antonio Magalhães Gomes Filho ao comentar o Projeto: "O que se buscou, portanto, foi superar os inconvenientes de certas disposições introduzidas pela Lei 11.690/2008, que revelam equívocos e imprecisões do legislador (...), capazes de comprometer o alcance da previsão constitucional", 430

Ademais, como já salientado, a inexistência de uma definição legal para provas ilícitas nunca se constituiu em óbice para a aplicação da regra inserta no artigo $5^{\circ}$, inciso LVI, da Constituição Federal.

Portanto pode-se concluir ser de bom tom a redação sugerida para o tema pelo PLS n⿳0 156/2009.

Em trâmite na Comissão de Constituição e Justiça do Senado, o PLS no 156/2009 foi aprovado sob a forma de substitutivo, de autoria do Senador Renato Casagrande.

Ainda naquela Casa, o substitutivo recebeu 214 emendas, das quais 65 foram aprovadas e outras 32 foram parcialmente aproveitadas como subemendas do relator.

O referido substitutivo foi aprovado pelo Plenário do Senado Federal em 07 de dezembro de 2010, como o Projeto de Lei daquela Casa para o Novo Código de Processo Penal.

\footnotetext{
${ }^{430}$ GOMES FILHO, Antonio Magalhães. A inadmissibilidade das provas ilícitas no processo penal brasileiro, p. 410.
} 
O texto aprovado foi encaminhado para a Câmara dos Deputados, onde será discutido e votado, sendo passível de ser emendado e, eventualmente, sequer ser aprovado. 


\section{PROVAS ILÍCITAS POR DERIVAÇÃO}

\subsection{Conceito}

A Suprema Corte Norte-Americana foi a responsável por desenvolver inicialmente a idéia de que as provas aparentemente lícitas, que fossem derivadas de uma prova originalmente ilícita, não seriam também aceitas nos autos do processo.

Trata-se da formulação da fruits of the poisonous tree doctrine, que veda, como regra, a admissão em quaisquer processos da prova derivada da obtida por meios ilícitos.

De fato, as provas aparentemente lícitas que sejam derivadas, direta ou indiretamente, de uma prova ilícita anterior serão também consideradas ilícitas por derivação e, portanto, inadmissíveis nos autos do processo.

Em outras palavras, a prova que mantenha com a prova obtida por meios ilícitos um nexo de causalidade não poderá ingressar nos autos do processo, sendo considerada ilícita por derivação.

Conforme explica Antonio Magalhães Gomes Filho "é impossível negar $a$ priori a contaminação da prova secundária pela ilicitude inicial, não somente por um critério de causalidade, mas principalmente em razão da finalidade com que são estabelecidas as proibições em análise. De nada valeriam tais restrições à admissibilidade da prova se, por via derivada, informações colhidas a partir de uma violação ao ordenamento pudessem servir ao convencimento do juiz - nessa matéria importa ressaltar o elemento profilático, evitando-se condutas atentatórias aos direitos fundamentais e à própria administração correta e leal da justiça penal $^{431}$,

Tal entendimento é compartilhado por Ada, Scarance e Magalhães: "Na posição mais sensível às garantias da pessoa humana, e conseqüentemente mais intransigente

${ }^{431}$ GOMES FILHO, Antonio Magalhães. Provas Lei 11.690, de 09.06.2008, p. 267. 
com os princípios e normas constitucionais, a ilicitude da obtenção da prova transmite-se às provas derivadas, que são, assim, igualmente banidas do processo". 432

Trata-se de fazer uma interpretação sistemática do quanto previsto no artigo $5^{\circ}$, inciso LVI, da Constituição Federal ${ }^{433}$.

De fato, pode-se afirmar que a ilicitude por derivação, em que pese não estar prevista de forma expressa em referida regra constitucional encontra-se por ela albergada. Assim, especial atenção merece a questão da prova ilícita por derivação por constituir-se a admissão dessa teoria no sistema brasileiro em uma conseqüência lógica e necessária a partir do quanto previsto na Constituição Federal.

Nos dizeres de Nereu José Giacomolli “não teria sentido vedar o uso da ilicitude e tolerar o seu aproveitamento interno. Admitir a prova lícita derivada de uma ilicitude seria incitar a utilização de procedimentos inconstitucionais que, indiretamente, surtiriam efeito $^{434}$.

Para Carlos Enrique Edwards a doutrina da ilicitude por derivação vai além das regras de exclusão, implicando um comportamento ético por parte do Estado, que não poderia se beneficiar de provas ilícitas ainda que de forma derivada ${ }^{435}$.

Ainda segundo o mesmo autor, trata-se de um único sistema, que apregoa a inadmissibilidade das provas ilícitas nos autos do processo, abordado em duas vertentes distintas e complementares: a aplicação das regras de exclusão às provas ilícitas originais e a adoção da ilicitude por derivação para a exclusão das provas derivadas ${ }^{436}$.

Conforme afirma Guilherme de Souza Nucci “de nada adiantaria preservar os direitos e garantias humanas fundamentais no nascedouro da produção da prova, permitindo-se depois, a utilização de derivações flagrantemente inconsistentes, pois calcadas em alicerces podres". 437

${ }^{432}$ GRINOVER, Ada Pellegrini; FERNANDES, Antonio Scarance; GOMES FILHO, Antonio Magalhães. As Nulidades no Processo Penal, p. 163.

${ }^{433}$ GOMES, Luiz Flávio; CUNHA, Rogério Sanches; PINTO, Ronaldo Batista. Comentários às Reformas do Código de Processo Penal e da Lei de Trânsito, p. 285.

${ }^{434}$ GIACOMOLLI, Nereu José. Reformas do Processo Penal: Considerações críticas, p. 40-41 e OLIVEIRA, Eugênio Pacelli. Curso de Processo Penal, p. 310.

${ }^{435}$ EDWARDS, Carlos Enrique. La prueba ilegal en el proceso penal. Cordoba: Editorial Cordoba, 2000, p. 9091.

${ }^{436}$ Conforme sustenta EDWARDS, Carlos Enrique. La prueba ilegal en el processo penal, p. 100.

${ }^{437}$ NUCCI, Guilherme de Souza. Provas no Processo Penal, p. 32. 
Portanto, não há que se olvidar que os elementos de prova secundários que, no caso prático, apenas se tornarem conhecidos em razão da obtenção da prova inicial de forma ilícita serão também maculados pela ilicitude anterior.

Dito de outra forma, as provas que derivarem, direta ou indiretamente, da prova obtida por meios ilícitos serão consideradas ilícitas por derivação e, portanto, inadmissíveis nos autos do processo.

\subsection{Evolução}

Até o advento da Lei $\mathrm{n}^{\circ}$ 11.690/08 inexistia em nosso ordenamento jurídico qualquer diploma legislativo que abordasse a questão da ilicitude por derivação, chamada também de teoria dos frutos da árvore envenenada ${ }^{438}$.

A despeito dessa falta de previsão legal o entendimento prevalente na doutrina e Jurisprudência da época era de que no Brasil as provas aparentemente lícitas que fossem derivadas de uma prova ilícita anterior seriam também elas consideradas ilícitas por derivação e, portanto, inadmissíveis no processo, devendo ser desentranhadas dos autos caso dele constassem por um equívoco.

Assim, em que pese a Constituição Federal não tratar expressamente das provas ilícitas por derivação, o entendimento predominante sempre foi o de que, como a norma prevista no artigo $5^{\circ}$, inciso LVI da Constituição Federal não faz qualquer distinção entre prova ilícita originária e prova ilícita por derivação, estaria a indicar que ambas são inadmissíveis nos autos do processo.

Esse posicionamento, aliás, já vinha sendo aventado pelo Supremo Tribunal Federal desde 1993, com um precedente de relatoria do Ministro Sepúlveda Pertence, julgado em Sessão Plenária de 30 de junho daquele ano ${ }^{439}$.

\footnotetext{
${ }^{438}$ A teoria desenvolvida pela Corte Suprema Norte-Americana no precedente Silverthorne Lumber Co. v. United States, segundo a qual as provas aparentemente lícitas que sejam derivadas, direta ou indiretamente, da prova ilícita anterior serão também eivadas do vício da ilicitude, ficou conhecida no Brasil como teoria da ilicitude por derivação, ou teoria dos frutos da árvore envenenada (ou venenosa), sendo chamada por Aury Lopes Júnior de princípio da contaminação. Vide JÚNIOR, Aury Lopes. Direito Processual Penal e sua Conformidade Constitucional. v. I, p. 589-590.
} 
O caso em questão tratava-se de uma ordem de habeas corpus impetrado no STF, requerendo a liberdade de paciente condenado por tráfico de drogas, em decisão confirmada em segunda instância, sob a alegação de que as provas constantes dos autos seriam ilícitas já que derivadas de interceptação telefônica ilegal. Segundo argumentou a defesa os elementos de prova obtidos a partir da escuta e gravação de comunicações telefônicas do réu, ainda que autorizadas judicialmente, não poderiam ser admitidas nos autos pois que inexistia à época diploma legislativo integrativo do artigo $5^{\circ}$, XII, da Constituição Federal ${ }^{440}$, não tendo sido, tampouco, recepcionado pela nova Constituição o artigo 57, II, “e”, da Lei 4.117/62

Conforme sustentado pela defesa do caso, a apreensão da droga e a própria prisão em flagrante do paciente apenas teriam sido concretizados em virtude de escuta telefônica anterior, efetivada sem autorização legal.

Tal argumentação foi acolhida pelo relator, fazendo constar de seu voto a primeira referência à teoria da ilicitude por derivação em julgados brasileiros. " $\mathrm{O}$ caso demanda aplicação da doutrina que a melhor jurisprudência americana constituiu sob a denominação de princípios dos fruits of the poisonous tree: é que às provas diversas do próprio conteúdo das conversações telefônicas interceptadas só se pode chegar, segundo a própria lógica da sentença, em razão do conhecimento delas, isto é, em consequiência da interceptação ilícita de telefonemas ${ }^{442,}$.

Conforme afirmou ademais o Ministro relator do caso "essa doutrina da (...) fruit of the poisonous tree é a única capaz de dar eficácia à garantia constitucional da

${ }^{439}$ STF - HC 69.912-0/RS - Relator Ministro Sepúlveda Pertence - DJU 26.11.1993. Vale destacar que, no caso em tela, em que pese a tese da ilicitude por derivação ter sido aventada pelo Relator, o Tribunal Pleno houve por bem denegar a ordem por maioria de votos, sob a justificativa de que o Acórdão impugnado se baseava também em outras provas que não decorrentes da interceptação telefônica e que, ademais, não seria cabível o exame apurado de provas em sede de habeas corpus. Entretanto, o caso teve ainda outros desdobramentos. Após a denegação do HC, a defesa impetrou mandado de segurança requerendo a concessão da segurança para que se anulasse a decisão anterior, tendo em vista que oficiou no feito como membro do Ministério Público o filho do então Ministro do STF, Néri da Silveira. O relator do mandamus, Ministro Carlos Velloso, não conheceu o mandado de segurança impetrado, mas, reconhecendo o impedimento legal suscitado, houve por bem expedir, de ofício, ordem de habeas corpus para determinar a nulidade do julgamento anterior. Assim, no novo julgamento proferido (DJU 25.03.1994) foi deferida a ordem acatando-se a tese da ilicitude por derivação, de forma que as provas decorrentes da interceptação telefônica ilegal estariam por ela viciadas, não sendo admissíveis nos autos do processo.

${ }^{440}$ Vale lembrar que atualmente a lei que regula as interceptações telefônicas é a Lei no 9296 de 24 de julho de 1996.

441 Disponível em: <http://www.jusbrasil.com.br/filedown/dev0/files/JUS2/STF/IT/HC 69912 RS\%20 30.06. 1993.pdf>. Acesso em: 25 ago. 2010.

442 Disponível em: <http://www.jusbrasil.com.br/filedown/dev0/files/JUS2/STF/IT/HC_69912_RS\%20_30.06. 1993.pdf>. Acesso em: 25 ago. 2010. 
inadmissibilidade da prova ilícita. De fato, vedar que se possa trazer ao processo a própria degravação das conversas telefônicas, mas admitir que as informações nela colhidas possam ser aproveitadas pela autoridade, que agiu ilicitamente, para chegar a outras provas, que sem tais informações não colheria, evidentemente, é estimular e, não, reprimir a atividade ilícita da escuta e da gravação clandestina de conversas privadas". ${ }^{443}$

Após este precedente inicial a adoção da teoria da ilicitude por derivação consolidou-se no Supremo Tribunal Federal ${ }^{444}$.

Entretanto, em que pese fosse amplamente majoritária, a tese da ilicitude de provas por derivação encontrava opositores ${ }^{445}$.

Ainda assim, atendendo ao quanto já vinha sendo defendido pela doutrina pátria dominante e pela Jurisprudência dos Tribunais Superiores, a Lei $n^{\circ}$ 11.690/08 incluiu no estatuto processual penal a previsão expressa da adoção no Brasil da ilicitude por derivação no parágrafo primeiro do artigo 157 do CPP, determinando serem também inadmissíveis as provas derivadas das ilícitas.

De fato, com a nova redação conferida ao artigo 157 do Código de Processo Penal, de forma expressa "optou-se pelo sistema da consideração da ilicitude das provas

443 Disponível em: <http://www.jusbrasil.com.br/filedown/dev0/files/JUS2/STF/IT/HC_69912_RS\%20_30.06. 1993.pdf>. Acesso em: 25 ago. 2010.

${ }^{444}$ Conforme constou do voto do Ministro Relator Celso de Mello no julgamento do RHC 90376/RJ, publicado no DJ de 18.05.2007: "Ninguém pode ser investigado, denunciado ou condenado com base, unicamente, em provas ilícitas, quer se trate de ilicitude originária, quer se cuide de ilicitude por derivação. Qualquer novo dado probatório, ainda que produzido, de modo válido, em momento subseqüente, não pode apoiar-se, não pode ter fundamento causal nem derivar de prova comprometida pela mácula da ilicitude originária. A exclusão da prova originariamente ilícita - ou daquela afetada pelo vício da ilicitude por derivação - representa um dos meios mais expressivos destinados a conferir efetividade à garantia do 'due process of law' e a tornar mais intensa, pelo banimento da prova ilicitamente obtida, a tutela constitucional que preserva os direitos e prerrogativas que assistem a qualquer acusado em sede processual penal. (...) A doutrina da ilicitude por derivação (teoria dos 'frutos da árvore envenenada') repudia, por constitucionalmente inadmissíveis, os meios probatórios, que, não obstante produzidos, validamente, em momento ulterior, acham-se afetados, no entanto, pelo vício (gravíssimo) da ilicitude originária, que a eles se transmite, contaminando-os, por efeito de repercussão causal. (...) Revelamse inadmissíveis, desse modo, em decorrência da ilicitude por derivação, os elementos probatórios a que os órgãos da persecução penal somente tiveram acesso em razão da prova originariamente ilícita (...)". No mesmo sentido vide ainda: STF HC 72.588/PB, Relator Ministro Maurício Corrêa, DJ 04.08.2000; STF HC 73.351/SP, Relator Ministro Ilmar Galvão, DJ 19.03.1999; STF RE 251.445/GO, Relator Ministro Celso de Mello, DJ 03.08.2000, STF HC 74.116/SP, Relator Ministro Néri da Silveira, DJ 14.03.1997; HC 76.641/SP, Relator Ministro Sepúlveda Pertence, DJ 02.02.1999.

${ }^{445}$ SILVA, César Dario Mariano da. Provas Ilícitas, p.31. O autor afirma in verbis: "Ousamos discordar da maioria dos membros do Supremo. Não vemos como não admitir no processo uma prova somente porque ela teve origem em uma prova ilícita. Se as provas angariadas, mesmo derivadas de uma ilícita, obedecerem a todos os princípios constitucionais e processuais, não há como desprezá-las”. 
conseqüentes, quando derivadas da prova ilícita original, constituindo uma estrutura lógica e racional", 446

Assim, os brocardos jurídicos "o veneno da árvore se transmite a todos os seus frutos"447 ou ainda "árvore envenenada não pode dar bons frutos",448 (fazendo alusão à nomenclatura dada às provas ilícitas por derivação pela Suprema Corte Norte-Americana), passaram a constituir disposição legal no ordenamento jurídico brasileiro.

Cumpre destacar, por oportuno, que essa previsão é mantida no caput do artigo 164 do Projeto de Novo Código de Processo Penal, em trâmite no Congresso Nacional.

Ademais, essas modificações legais inseridas pela Lei $n^{\mathbf{0}} 11.690 / 2008$ no Código de Processo Penal vigente, além de trazerem para o CPP a previsão expressa da adoção no Brasil da ilicitude por derivação, previram também de forma expressa ressalvas à ilicitude por derivação no ordenamento processual penal brasileiro.

\subsection{Mitigações à ilicitude por derivação}

Conforme já salientado, atenuações à teoria dos frutos da árvore envenenada foram expressamente incorporadas ao ordenamento jurídico pátrio com os parágrafos $1^{\circ}$ e $2^{\circ}$ do artigo 157 do CPP.

Essas mitigações, desenvolvidas uma vez mais pela Corte Estadunidense e trazidas para o sistema processual penal brasileiro por meio da Lei $n^{\circ}$ 11.690/08 serão estudadas tendo-se em conta a implicação jurídica de tais previsões em face da regra constitucional de vedação das provas ilícitas, disposta no artigo $5^{\circ}$, inciso LVI, da CF.

\footnotetext{
${ }^{446}$ NUCCI, Guilherme de Souza. Provas no Processo Penal, p. 32.

${ }^{447}$ MENDONÇA, Andrey Borges de. Nova Reforma do Código de Processo Penal, p. 167.

${ }^{448}$ NUCCI, Guilherme de Souza. Provas no Processo Penal, p. 32.
} 


\subsubsection{Limites à imposição de restrições legais}

Conforme já exposto, a despeito de inexistir menção expressa no texto constitucional acerca da ilicitude por derivação, certo é que as provas secundárias derivadas da prova ilícita anterior estarão eivadas do mesmo vício. É que, deve ser feita uma interpretação lógica do quanto disposto no artigo $5^{\circ}$, inciso LVI, da CF para abarcar em seu teor também as provas ilícitas por derivação, como forma de melhor tutelar direitos fundamentais e garantir eficácia à regra constitucional.

Nos dizeres de Ingo Wolfgang Sarlet "na Constituição também está incluído o que não foi expressamente previsto, mas que implícita e indiretamente pode ser deduzido". ${ }^{449}$

Portanto, certo é que a vedação às provas ilícitas por derivação têm tutela constitucional implícita, cumprindo agora analisar em que termos se dá essa proteção.

A regra inserta no artigo $5^{\circ}$, inciso LVI, da Constituição Federal, a vedar a admissibilidade no processo das provas originalmente ilícitas e também das provas ilícitas por derivação, não prevê em sua redação qualquer ressalva.

A despeito disso, é cediço que os direitos fundamentais não são absolutos, devendo ser compatibilizados com outros direitos de mesma magnitude e hierarquia constitucional quando de sua aplicação ao caso concreto, seja pela atuação do legislador ou do Magistrado ${ }^{450}$.

Segundo Robert Alexy, direitos fundamentais podem ser restringidos somente por normas de hierarquia constitucional ou em virtude delas. Ou seja, poderão ser restringidos por normas de hierarquia constitucional, e nesse caso serão consideradas restrições diretamente constitucionais, ou em virtude de normas infraconstitucionais cuja criação seja autorizada constitucionalmente (ainda que não expressamente) e serão então chamadas restrições indiretamente constitucionais ${ }^{451}$.

Como já salientado, o artigo $5^{\circ}$, inciso LVI, da Constituição Federal está previsto no capítulo que trata dos direitos e deveres individuais e coletivos, no título dos

${ }^{449}$ Conforme SARLET, Ingo Wolfgang. A eficácia dos direitos fundamentais, p. 93.

${ }^{450}$ Conforme explanação de ALEXY, Robert. Teoria dos Direitos Fundamentais, p. 111.

${ }^{451}$ ALEXY, Robert. Teoria dos Direitos Fundamentais, p. 286-295. 
direitos e garantias fundamentais, constituindo-se, portanto, o direito à inadmissibilidade das provas ilícitas em um direito individual fundamental.

Como tal, e conforme também já aventado, não há que se olvidar que o direito à inadmissibilidade das provas ilícitas encontra amparo no quanto previsto no artigo $60, \S 4^{\circ}$, inciso IV, da Constituição Federal configurando uma cláusula pétrea ${ }^{452}$.

Segundo disposto no $\S 4^{\circ}$ do artigo 60 da CF são vedados quaisquer projetos de emenda constitucional tendentes a abolir a forma federativa de Estado, o voto direto, secreto, universal e periódico, a separação dos poderes e os direitos e garantias individuais ${ }^{453}$. Ou seja, no que diz respeito a este trabalho, a referida norma constitucional tem como objetivo impedir qualquer proposta de emenda constitucional que vise a mitigar ou reduzir o significado e a eficácia dos direitos e garantias individuais ${ }^{454}$, dentre os quais se insere o direito à prova lícita, consubstanciado a contrario sensu, na regra disposta no artigo $5^{\circ}$, inciso LVI, da Constituição Federal.

Aliás é sabido que o Supremo Tribunal Federal considera serem cláusulas pétreas todas as matérias elencadas no artigo $5^{\circ}$ da Constituição Federal, dentre outras ${ }^{455}$.

Nesse sentido, a regra disposta no artigo $5^{\circ}$, inciso LVI, da Constituição Federal não poderá ter seu alcance de proteção restringido por emenda constitucional.

O referido dispositivo constitucional enquadra-se na classificação de Gilmar Ferreira Mendes ${ }^{456}$ dentre os direitos fundamentais sem expressa previsão de reserva legal. Isso significa dizer que a Constituição Federal, ao contrário do que ocorre com outros direitos, não previu a necessidade deste direito ter seu alcance de proteção restringido por lei, com vistas a evitar eventuais colisões de direitos no caso concreto. O que não impede, todavia, que este direito seja efetivamente objeto de sopesamento quando se verificar concretamente a

\footnotetext{
${ }^{452}$ SARLET, Ingo Wolfgang. A eficácia dos direitos fundamentais, p. 88-89.

${ }^{453}$ Isso sem falar das cláusulas pétreas implícitas, admitidas pela doutrina e pelo STF, como a própria cláusula de imutabilidade material disposta no artigo $60, \S 4^{\circ}$ da Constituição Federal. Em que pese esta disposição não estar prevista expressamente como cláusula pétrea não poderá ser objeto de ab-rogação, sob pena de ser desnaturada a própria limitação material imposta ao Poder Constituinte Derivado Reformador. Conforme MENDES, Gilmar Ferreira; COELHO, Inocêncio Mártires; BRANCO, Paulo Gustavo Gonet. Curso de Direito Constitucional, p. 262.

${ }^{454}$ MENDES, Gilmar Ferreira; COELHO, Inocêncio Mártires; BRANCO, Paulo Gustavo Gonet. Curso de Direito Constitucional, p. 255.

455 MACHADO, Antônio Cláudio da Costa (Org.). Constituição Federal Interpretada: artigo por artigo, parágrafo por parágrafo. Barueri: Manole, 2010, p. 461.

${ }^{456}$ MENDES, Gilmar Ferreira; COELHO, Inocêncio Mártires; BRANCO, Paulo Gustavo Gonet. Curso de Direito Constitucional, p. 347.
} 
colisão de algum outro direito fundamental com o direito à prova lícita, ou de que este direito seja regulamentado por lei, desde que tal regulamentação/restrição seja constitucionalmente justificável, isto é, seja proporcional ${ }^{457}$. Até porque, nos dizeres de Virgílio Afonso da Silva, "todas as normas constitucionais podem ser restringidas pela legislação ordinária" ${ }^{4} 8$

Segundo Virgílio Afonso da Silva, regulamentar o exercício de um direito fundamental equivale a restringir o exercício do referido direito tão somente às formas regulamentadas $^{459}$. Dito de outra forma: toda regulamentação implicará restrição.

De fato, como explana o referido constitucionalista, as normas constitucionais ainda que sem expressa previsão de reserva legal poderão sofrer regulamentação infraconstitucional com o objetivo de compatibilizar o exercício de direitos fundamentais colidentes, desde que tal restrição seja proporcional e neste sentido constitucionalmente justificável.

Desse modo, a eventual inconstitucionalidade do artigo 157 do CPP (conforme será abordado adiante) não decorre do simples fato deste dispositivo restringir o quanto previsto no artigo $5^{\circ}$, inciso LVI, da Constituição Federal, mas porque o faz de maneira desproporcional.

Em verdade, ao que parece - e conforme será abordado nos itens seguintes - o artigo 157 do Código de Processo Penal brasileiro em sua nova redação traz limitações excessivas e desproporcionais à inadmissibilidade da prova ilícita em sua faceta derivada e que, portanto, não podem ser admitidas.

Assim, há que se concluir que exceções desproporcionais impostas por lei à ilicitude por derivação, como feitas em alguns pontos pela Lei $\mathrm{n}^{\circ} 11.690 / 08$, não podem ser aceitas, sendo certo que os hard cases em matéria de ilicitude probatória quando verificados no caso concreto deverão ser analisados em suas especificidades e propostas soluções particulares e constitucionalmente justificáveis para o caso a caso, como com a aplicação da regra da proporcionalidade.

${ }^{457}$ Sobre as condições para restrições de direitos fundamentais vide: SILVA, Virgílio Afonso da. Direitos Fundamentais: conteúdo essencial, restrições e eficácia, p. 126 ss.

${ }^{458}$ SILVA, Virgílio Afonso da. Direitos Fundamentais: conteúdo essencial, restrições e eficácia, p. 223.

${ }^{459}$ SILVA, Virgílio Afonso da. Direitos Fundamentais: conteúdo essencial, restrições e eficácia, p. $100 \mathrm{ss}$. Nas palavras do autor nas páginas 209 e 210: "Toda regulação é, ao mesmo tempo, uma restrição, já que regular o exercício de um direito implica excluir desse exercício aquilo que a regulação deixar de fora; e, além disso, toda restrição é, ao mesmo tempo, regulação, já que não se restringe direito fundamental sem fundamentação, mas sempre com o objetivo de harmonizar o exercício de todos eles". 
A doutrina, contudo, diverge sobre o tema.

Para Ivan Luís Marques da Silva: “A Constituição Federal trouxe uma regra, em tese, sem exceções. Qualquer ressalva a essa garantia constitucional só será admitida se também for derivada de regra materialmente constitucional. Desta forma, o legislador não poderia, em hipótese nenhuma reduzir o alcance do inc. LVI do art. $5^{\circ}$ da CF valendo-se de uma lei ordinária". 460

Também para Flaviane de Magalhães Barros "o texto como foi aprovado é inconstitucional. Isso porque o legislador ordinário não pode excepcionar uma garantia constitucional ao seu alvedrio". 461

Kai Ambos e Fauzi Hassan Choukr, por outro lado, ponderam o rigor da regra constitucional, sustentando a legalidade e constitucionalidade das restrições impostas pelos parágrafos do artigo 157 do CPP. Para os autores o ordenamento pátrio não deve importar doutrinas estrangeiras, como a dos frutos da árvore envenenada, de forma passiva e acrítica, sem que incorpore também as exceções desenvolvidas à tal teoria em seu país de origem, como ocorre com a teoria da descoberta inevitável ${ }^{462}$.

Foi, em certa medida, também este o entendimento exarado pela Comissão de Juristas constituída para propor alterações ao Código de Processo Penal.

De fato, conforme constou da Exposição de Motivos do Anteprojeto referente às provas este "estabelece a inadmissibilidade das provas ilícitas por derivação, de acordo com a teoria dos 'frutos da árvore envenenada', com as cautelas aceitas pela jurisprudência norteamericana: ou seja, a inadmissibilidade fica restrita aos casos em que fique evidenciado o nexo de causalidade entre as ilícitas e as lícitas e quando se verificar que as derivadas não pudessem ser obtidas senão por meio das primeiras". ${ }^{463}$

Aury Lopes Júnior tratando também do artigo $5^{\circ}$, inciso LVI, da Constituição Federal sustenta que não deve ser feita uma interpretação literal da regra constitucional pretendendo a absolutização da vedação. Segundo o autor, "a inadmissibilidade absoluta tem a

\footnotetext{
${ }^{460}$ SILVA, Ivan Luís Marques da. Reforma Processual Penal de 2008: Lei 11.719/2008 (Procedimentos Penais), Lei 11.690/2008 (Provas), Lei 11.689/2008 (Júri), Comentadas artigo por artigo, p. 68.

461 BARROS, Flaviane de Magalhães. (Re)forma do Processo Penal: Comentários críticos dos artigos modificados pelas Leis $n$. 11.690/08, n. 11.719/08 e $n .11 .900 / 09$, p. 43.

${ }^{462}$ AMBOS, Kai; CHOUKR, Fauzi Hassan. A Reforma do Processo Penal no Brasil e na América Latina, p. 148.

463 Mensagem 211, MJ, Diário da Câmara dos Deputados, de 30 mar. 2001, p. 9474. Disponível em: <http://imagem.camara.gov.br/diarios.asp>. Acesso em: 19 ago. 2010.
} 
absurda pretensão de conter uma razão universal e universalizante, que pode(ria) prescindir da ponderação exigida pela complexidade que envolve cada caso na sua especificidade". ${ }^{464}$

De todo modo, apesar do intenso debate existente acerca dos limites aplicáveis à imposição de restrições legais à regra constitucional de vedação das provas ilícitas incluindo para alguns inclusive a discussão acerca da própria possibilidade (ou não) de imposição de restrições por meio de leis infraconstitucionais àquela regra - a nova redação conferida ao artigo 157 do Código de Processo Penal, alheia a discussão inseriu no Código “exceções” à ilicitude por derivação, que em alguns pontos beiram a inconstitucionalidade, como será visto a seguir.

\subsubsection{Análise das hipóteses trazidas pelo Código de Processo Penal}

Nos próximos subitens serão analisadas as mitigações à teoria da ilicitude por derivação aventadas pelo Código de Processo Penal brasileiro.

Conforme consta do parágrafo primeiro do artigo 157 do CPP as provas secundárias serão admissíveis nos autos do processo quando não evidenciado o nexo de causalidade entre a ilicitude inicial e a prova decorrente, ou ainda no caso de fonte independente.

O parágrafo $2^{\circ}$ do mesmo dispositivo a pretexto de trazer uma definição legal para fonte independente acaba por inserir no Código nova modalidade mitigatória da regra geral acerca da ilicitude por derivação, chamada teoria da descoberta inevitável.

Assim, serão abordadas as limitações à teoria dos frutos da árvore venenosa chamadas de fonte independente (independent source limitation or doctrine), descoberta inevitável (inevitable discovery exception) e teoria do nexo causal atenuado (attenuated connection doctrine) também conhecida como exceção do vício (ou mancha) diluídos (purged taint exception) ou ainda teoria da contaminação expurgada.

\footnotetext{
${ }^{464}$ JÚNIOR, Aury Lopes. Direito Processual Penal e sua Conformidade Constitucional. v. I, p. 585.
} 
Nesse ponto será analisado em que medida essas alterações legais, ainda pouco discutidas a fundo em razão da recenticidade da previsão normativa, afrontam o quanto previsto no artigo $5^{\circ}$, inciso LVI da Constituição Federal.

Ressalte-se, por oportuno, que serão abordadas no trabalho tão somente às mitigações à ilicitude por derivação, não sendo objeto de estudo eventuais exceções doutrinárias trazidas à prova originalmente ilícita, por uma opção de corte metodológico.

As hipóteses serão vistas a seguir, começando pela teoria da fonte independente.

\subsubsection{Fonte independente}

A Lei 11.690/08 insere no sistema normativo brasileiro, a chamada "exceção" à ilicitude por derivação da independent source, criada pela Suprema Corte dos Estados Unidos no precedente Silverthorne Lumber Co. v. United States ${ }^{465}$, em 1920, e desenvolvida décadas mais tarde no caso Bynum v. United States, em $1960^{466}$.

Bynum havia sido preso ilegalmente, suspeito da prática de um roubo. $\mathrm{Na}$ prisão foram colhidas suas impressões datiloscópicas. A partir desse elemento de prova foi possível identificá-lo como um dos agentes do crime. Entretanto, a Corte daquele país entendeu pela exclusão de referidos elementos de prova, pois que derivavam da prisão ilegal do indivíduo.

Ocorre que as impressões digitais de Bynum constavam já, ao tempo da prisão, dos arquivos do FBI e assim puderam ser levadas em conta no julgamento do caso pelo Tribunal Superior dos EUA, que considerou tratar-se de uma fonte autônoma de prova e anterior em relação à prova ilicitamente obtida.

De fato, a "exceção" da fonte independente apregoa que um elemento de prova não será considerado viciado, e será, portanto admissível nos autos do processo, se for obtido

\footnotetext{
${ }^{465} \mathrm{O}$ precedente foi já retratado no trabalho no tópico 2.1 .

${ }^{466}$ Disponível em: 〈http://openjurist.org/274/f2d/767/bynum-v-united-states>. Acesso em: 24 nov. 2010.
} 
por uma fonte de prova diversa daquela em que se tenha configurado a ilicitude, desde que essa fonte seja anterior ou concomitante à ilegalidade praticada.

Trata-se de uma fonte autônoma, uma via distinta de aquisição de prova que tenha levado aos mesmos elementos obtidos de maneira ilícita ${ }^{467}$.

A idéia da Suprema Corte ao desenvolver essa mitigação era a de que as provas derivadas das ilícitas não poderiam ser admitidas nos autos sob pena de incentivar e não coibir as más condutas policiais. Entretanto, quando os mesmos elementos de prova fossem obtidos de maneira autônoma e anterior à conduta ilegal seriam admissíveis nos autos do processo, sob pena de, em assim não sendo, deixar a Polícia em uma situação pior do que a que estaria caso não tivesse praticado a ilegalidade. Isto porque se os agentes policiais tivessem atuado conforme a lei poderiam ter se valido do referido elemento de prova obtido pela fonte autônoma.

O entendimento da Corte Norte-Americana era de que o interesse da sociedade em dissuadir condutas policiais atentatórias de direitos constitucionais e o interesse público em buscar a maior quantidade de provas acerca de um suposto crime posto sub judice estariam adequadamente balanceados com a colocação da Polícia na mesma situação, e não em uma posição pior, do que a que se encontraria caso tivesse atuado nos estritos limites da legalidade $^{468}$.

No Brasil essa hipótese mitigatória era já aplicada pelo Supremo Tribunal Federal mesmo antes de sua previsão legal no ordenamento pátrio ${ }^{469}$.

Cumpre notar, contudo, que não há nesse caso verdadeira exceção à prova ilícita, mas ausência de nexo causal entre a ilicitude e a prova obtida por uma fonte independente. Em verdade não há aqui relação de causalidade que possa remeter a prova ilícita à fonte autônoma e legal.

${ }^{467}$ EDWARDS, Carlos Enrique. La prueba ilegal en el proceso penal, p. 127.

${ }^{468}$ KAMISAR, Yale; LAFAVE, Wayne; ISRAEL, Jerold. Modern Criminal Procedure: Cases Comments and Questions, p. 818-819.

${ }_{469}$ Conforme constou de trecho do voto do Ministro Relator Celso de Mello no julgamento do RHC 90376/RJ, publicado no DJ de 18.05.2007: "Se, no entanto, o órgão da persecução penal demonstrar que obteve, legitimamente, novos elementos de informação a partir de uma fonte autônoma de prova - que não guarde qualquer relação de dependência nem decorra da prova originariamente ilícita, com esta não mantendo vinculação causal -, tais dados probatórios revelar-se-ão plenamente admissíveis, porque não contaminados pela mácula da ilicitude originária”. 
Nos dizeres de Antonio Magalhães Gomes Filho, "nem mesmo seria correto falar em exceção à regra de contaminação da prova derivada, pois na verdade o que se exclui é a própria relação de causalidade". ${ }^{470}$

Pode-se afirmar, portanto, que em aludida hipótese o fruto não deriva da árvore envenenada ${ }^{471}$.

De fato, o elemento de prova que advier de prova ilícita será considerado ilícito por derivação. Entretanto, poderá ingressar nos autos se no caso concreto houver uma fonte autônoma de provas, obtida de forma regular, que seja anterior ou concomitante à ilicitude praticada e que tenha conduzido o investigador ao mesmo elemento de prova obtido de maneira ilegal. A rigor, o elemento de prova admissível será aquele advindo da fonte independente e não o ilícito.

Verifica-se aqui que a prova é obtida pela fonte independente ainda antes da prática da ilicitude ou de maneira concomitante a esta, de modo que a prova advinda da fonte autônoma é já uma realidade quando a ilegalidade é cometida ${ }^{472}$.

Assim, nesse caso a prova derivada permanecerá ilícita e inadmissível no processo, sendo apenas aceitos nos autos os elementos de prova que sejam considerados como advindos de fonte autônoma e conforme a lei.

Portanto não há nessa hipótese qualquer ofensa ao quanto disposto no artigo $5^{\circ}$, inciso LVI, da Constituição Federal.

\subsubsection{Inexistência de nexo de causalidade entre as provas ilícitas e as} provas secundárias

O parágrafo $1^{\circ}$ do artigo 157 do CPP prevê ainda que não serão desentranhados dos autos os elementos de prova que não tiverem evidenciado o nexo de causalidade para com as provas consideradas ilícitas.

\footnotetext{
${ }^{470}$ GOMES FILHO, Antonio Magalhães. Provas Lei 11.690, de 09.06.2008, p. 268.

${ }^{471}$ BLOOM, Robert; BRODIN, Mark. Criminal Procedure: Examples and Explanatios, p. 209.

${ }^{472}$ É este também o entendimento de EDWARDS, Carlos Enrique. La prueba Ilegal en el Proceso Penal, p. 129. Segundo o autor de outro modo, a fonte independente se igualaria à descoberta inevitável.
} 
Para que se configure a hipótese em questão faz-se necessário demonstrar a inexistência de nexo causal entre as duas provas.

Também aqui não há propriamente uma exceção à teoria da ilicitude por derivação, mas ausência de pressuposto necessário à aplicação da regra ${ }^{473}$. Ou seja, para que tome lugar a ilicitude por derivação é imprescindível que a prova secundária derive direta ou indiretamente da prova ilícita originária.

Nereu José Giacomolli posiciona-se também nesse sentido, ao indagar: "Mas, se não há nexo causal, se poderia falar em prova derivada? Penso que não, pois não haveria dependência e nem conexão". 474

Ora, se inexiste relação de continuidade e interdependência entre as provas primárias e posteriores não há que se falar em aplicação da ilicitude por derivação.

No tocante a esta previsão normativa Antonio Magalhães Gomes Filho assim se manifesta: "Era perfeitamente desnecessária a previsão normativa, na medida em que o conceito de prova derivada supõe, por si só, a existência de uma relação de causalidade entre a ilicitude da primeira prova e a obtenção da segunda. Se o vínculo não estiver evidenciado, é intuitivo que não se trata de prova derivada". ${ }^{475}$

Nas palavras de Guilherme de Souza Nucci "na realidade, as duas exceções legais não configuram provas ilícitas por derivação", ${ }^{476}$ pois, conforme explana o autor, em ambos os casos tratados pelo parágrafo primeiro do artigo 157 do CPP inexiste nexo causal entre a prova ilícita e a prova secundária, a qual será, portanto, admissível nos autos do processo.

Entretanto é importante notar que há quem vislumbre nessa menção legislativa à "não evidenciação do nexo de causalidade entre as provas consideradas ilícitas e as provas secundárias" uma inclinação para a mitigação norte-americana da taint doctrine, também chamada de purged taint exception ou attenuated connection doctrine.

Esta "exceção" do vício diluído, desenvolvida pela Suprema Corte dos Estados Unidos a partir do caso Wong Sun v. U.S 477 em 1963 considera que a prova secundária, sob um

\footnotetext{
${ }^{473}$ Nesse sentido BARROSO, Marcelo Lopes. Reformas no Processo Penal, p. 103.

${ }^{474}$ GIACOMOLLI, Nereu José. Reformas do Processo Penal: Considerações críticas, p. 43.

475 GOMES FILHO, Antonio Magalhães. Provas Lei 11.690, de 09.06.2008, p. 268.

${ }^{476}$ NUCCI, Guilherme de Souza. Provas no Processo Penal, p. 34.

${ }^{477}$ Conforme retratado no tópico 2.1 do trabalho.
} 
viés puramente abstrato, se colocaria em uma linha de continuidade em relação à prova ilícita inicial, mantendo com ela uma condição de causa e efeito. Entretanto, em razão dos eventos ocorridos no caso concreto o nexo causal referido acaba por ser atenuado ou até mesmo dissipado.

Portanto, de acordo com essa mitigação à teoria dos frutos da árvore envenenada, apenas na análise do caso concreto será possível constatar a ausência de relação entre a prova ilícita e as provas secundárias pelos próprios acontecimentos do fato sub judice. Em verdade não há que se fazer uma análise hipotética e conceitual acerca do tema, mas uma observação concreta, pontual e feita no "caso a caso".

De fato, para a boa aplicação da atenuação à ilicitude derivada da purged taint exception, a Suprema Corte Norte-Americana desenvolveu, ao longo de seus julgados, uma série de fatores que devem ser considerados na análise do caso concreto.

Conforme os ensinamentos da Corte pioneira, para que o nexo causal entre a ilicitude anterior e a prova subseqüente seja considerado desfeito é condição sine qua non atentar-se para os seguintes pontos: (i) o período transcorrido entre a ilegalidade e a aquisição da prova secundária; (ii) a ocorrência de eventos intervenientes dentre esses dois momentos paradigmas; (iii) se a ilegalidade inicial praticada no caso era flagrante ${ }^{478}$.

Com relação ao intervalo de tempo transcorrido entre a obtenção da prova ilícita e a prova secundária que tem sua legalidade discutida apregoa a Corte que, quanto maior for o período verificado no caso concreto, mas tênue será a ligação entre ambas as provas.

Além disso, quanto mais eventos se inserirem no curso da cadeia existente entre a prova ilícita e as provas posteriores, mais frágil será a conexão entre elas.

Em relação a esse ponto cumpre salientar que a Suprema Corte dos Estados Unidos, analisando o caso a caso, tende a considerar que eventos que representam uma decisão livre e consciente do indivíduo são capazes de quebrar o nexo de causalidade entre a prova ilícita e a prova posterior, tornando-a admissível nos autos do processo. É o que ocorre, por

\footnotetext{
${ }^{478}$ BLOOM, Robert; BRODIN, Mark. Criminal Procedure: Examples and Explanatios, p. 208 e KAMISAR, Yale; LAFAVE, Wayne; ISRAEL, Jerold. Modern Criminal Procedure: Cases Comments and Questions, p. 808809.
} 
exemplo, no caso de interrogatórios prestados após ser dada ciência prévia ao interrogando de seus direitos consubstanciados nos Miranda warnings $^{479}$.

Há, porém, entendimento mais restritivo, no sentido de que para que as declarações proferidas sejam admissíveis como elemento de prova nos autos do processo, além de ser dada ciência ao interrogando de seus direitos (de fazer-se acompanhar por advogado, de manter-se silente etc.) é preciso cientificá-lo da inadmissibilidade da prova anteriormente produzida contra ele.

A mais alta Corte Argentina determina também uma maior ou menor aplicação da doutrina dos frutos da árvore envenenada conforme se trate de uma prova documental ou material (que se refere a objetos, como instrumentos do crime, por exemplo) ou de uma prova testemunhal (também chamada de prova pessoal).

De fato, nas primeiras é maior a probabilidade dessa ser considerada ilícita por derivação. Já no caso de uma prova testemunhal deverá haver um vínculo mais imediato para determinar a ilegalidade, tendo em vista ser inerente a esse meio de prova a voluntariedade e a autonomia $^{480}$.

Por outro lado, certo é que quanto mais flagrante e deliberada for a violação constitucional na obtenção de provas, maiores serão as razões para que todas as provas obtidas a partir da ilegalidade inicial sejam desconsideradas e desentranhadas dos autos.

Para Nereu José Giacomolli há que se diferenciar as situações. No caso de inexistir, desde o princípio, nexo de causalidade entre a prova ilícita e as secundárias, estas serão perfeitamente admissíveis nos autos do processo. Esta seria a hipótese elencada no artigo $157, \S 1^{\circ}$, do CPP. Já no caso do nexo de causalidade inicialmente existente entre a prova originalmente ilícita e a prova secundária ser atenuado por eventos ocorridos no caso concreto, a inadmissibilidade da prova secundária deverá ser mantida. Segundo o autor havendo conexão ou dúvida acerca desta haverá contaminação ${ }^{481}$.

\footnotetext{
${ }^{479}$ BLOOM, Robert; BRODIN, Mark. Criminal Procedure: Examples and Explanatios, p. 340-341.

${ }^{480}$ Conforme aponta o autor, discordando contudo de tal diferenciação: EDWARDS, Carlos Enrique. La prueba Ilegal en el Proceso Penal, p. 117-119.

${ }^{481}$ GIACOMOLLI, Nereu José. Reformas do Processo Penal: Considerações críticas, p. 46. A respeito do tema o autor assim se manifesta na página 43: "Situação diversa é a da ruptura do nexo de causalidade. Este existiu, mas rompeu-se ou foi desfeito. Nessa perspectiva, a debilidade do nexo causal entre as duas situações, mantém a inadmissibilidade (regra geral)". Mais adiante o autor reitera: "Observa-se que, pela interpretação do art. 157, parágrafo $1^{\circ}$, do CPP, há inadmissibilidade da 'prova' ilícita derivada mesmo na debilidade da conexão e nas hipóteses em que tenha havido atenuação dessa conexão".
} 
Para Marcos Alexandre Coelho Zilli a única finalidade da referida previsão inserta no artigo $157, \S 1^{\circ}$, do CPP seria para deixar claro que a mitigação da conexão tênue (ou "exceção" do vício diluído) não é admitida no sistema brasileiro, ou de outro modo tal redação legal seria absolutamente dispensável. De acordo com o autor, "somente a ausência completa de causalidade é que obsta a contaminação. Configurado um vínculo, ainda que remoto, o vício se propaga e a inadmissibilidade probatória amplia os seus horizontes". ${ }^{482}$

Segundo Andrey Borges de Mendonça, por outro lado, não está clara a posição do legislador brasileiro em relação à teoria do vício diluído. Assim, deverá a questão ser resolvida na análise do caso concreto, de forma a evidenciar a existência ou não de conexão entre a prova ilícita e a prova secundária, e então determinar a admissibilidade ou não do elemento de prova nos autos do processo ${ }^{483}$.

De fato, em que pese não estar clara a opção do legislador pátrio acerca da adoção ou não da teoria do nexo causal atenuado, entende-se necessária a sua rejeição, por não ser proporcional a sua admissão.

Conforme já salientado, restrições à direitos fundamentais para serem constitucionais devem ser motivadas pela compatibilização do exercício de direitos fundamentais colidentes e respeitar a regra da proporcionalidade.

A adoção da teoria do vício atenuado, não parece preencher essas condições. Ao revés, sua admissão pode dar margens a arbitrariedades, com a conseqüente restrição em demasia do direito à inadmissibilidade das provas ilícitas. Em verdade é possível que, com base nesta exceção se argumente pela adoção de qualquer prova ilícita por derivação sustentando-se que no caso estaria atenuada a relação de causalidade entre as provas. Assim pode-se sustentar que tal mitigação ainda que seja adequada a permitir a perquirição Estatal de forma mais efetiva, não se mostra necessária e nem tampouco proporcional em sentido estrito.

Ademais, conforme já mencionado, apenas a análise do caso concreto e em razão das especificidades constatadas naquele evento poderá ser evidenciada a inexistência de

${ }^{482}$ ZILLI, Marcos Alexandre Coelho. O pomar e as pragas. Boletim IBCCRIM, São Paulo, ano 16, n. 188, jul. 2008 , p. 3.

${ }^{483}$ MENDONÇA, Andrey Borges de. Nova Reforma do Código de Processo Penal, p. 172. A respeito da teoria da conexão atenuada assim se manifesta o autor: "Não restou clara a adoção pelo legislador, pois, (...) há um certo nexo - embora distante - entre a prova colhida e a ilícita. Certamente o caso concreto e a jurisprudência poderão confrontar-se com situações em que o nexo seja tão distante entre a prova ilícita e a prova obtida que se poderia pensar em um afastamento (ao menos normativo) deste nexo. A depender do caso concreto, a teoria da contaminação expurgada poderia ser enquadrada na hipótese ampla do $\S 1^{\circ}$ do art. 157”. 
liame causal entre a prova ilícita e a prova posterior. De todo modo, dificilmente será possível constatar na hipótese em comento a independência causal absoluta entre a prova ilícita e a outra, de modo a considerar esta última admissível nos autos do processo $^{484}$.

Portanto, em conformidade com o quanto previsto na Constituição Federal, cumpre considerar que a doutrina do nexo causal atenuado não foi adotada pelo Código de Processo Penal, já que diante do quanto disposto no artigo $5^{\circ}$, inciso LVI, da Constituição Federal apenas poderão ser admitidos nos autos do processo os elementos de prova que não detenham nenhum vínculo com a prova obtida ilicitamente, não bastando que o vínculo seja atenuado ou remoto.

\subsubsection{Descoberta inevitável}

É importante notar que a redação do artigo 157 do CPP, já bastante criticada em seu caput e $\S 1^{\circ}$, torna-se ainda mais confusa tendo-se em conta que o legislador pátrio ao pretender definir fonte independente no parágrafo segundo do dispositivo, acabou por inserir no Código a definição de descoberta inevitável ${ }^{485}$, verdadeira exceção à aplicação da teoria dos frutos da árvore envenenada.

A exceção da descoberta inevitável dispõe que, na análise do fato probando, podem ser considerados elementos de prova advindos de provas obtidas por meios ilícitos, caso se entenda que, esses elementos de prova seriam inevitavelmente descobertos em atuações conforme a lei ${ }^{486}$. Ou seja, demonstrado que, no caso concreto a prova ilegal seria inevitavelmente descoberta e legalmente colhida em razão de investigações já em curso quando da prática da ilegalidade, e o seria nas mesmas condições em que o foi, em função da

${ }^{484}$ JÚNIOR, Aury Lopes. Direito Processual Penal e sua Conformidade Constitucional. v. I, p. 597. Nesse sentido afirma o autor: "A noção de nexo causal em matéria de contaminação probatória exige uma análise séria e desapaixonada, de modo que somente as provas absolutamente independentes podem permanecer".

${ }^{485}$ No mesmo sentido vide: GIACOMOLLI, Nereu José. Reformas do Processo Penal: Considerações críticas, p. 46; PRADO, Leandro Cadenas. Provas ilícitas: Teoria e interpretação dos Tribunais Superiores, p. 18; OLIVEIRA, Eugênio Pacelli. Curso de Processo Penal, p. 310 e FEITOZA, Denilson. Reforma Processual Penal: uma abordagem sistêmica, p. 199. Em sentido contrário, sustentando ser a definição do parágrafo $2^{\circ}$ do artigo 157 do CPP de fonte independente, propriamente, vide NUCCI, Guilherme de Souza. Provas no Processo Penal, p. 35-36.

${ }^{486}$ BLOOM, Robert; BRODIN, Mark. Criminal Procedure: Examples and Explanatios, p. 209. 
ilicitude cometida, a prova ilícita não seria excluída dos autos, mas levada em conta pelo julgador na decisão do caso ${ }^{487}$.

De acordo com essa exceção à ilicitude derivada, a questão está em saber se referidos elementos de prova seriam inevitavelmente ou provavelmente ou até mesmo eventualmente descobertos ${ }^{488}$. Faz-se aqui, portanto, um juízo hipotético e não um juízo de certeza.

A inevitable discovery exception foi desenvolvida pela Suprema Corte NorteAmericana em 1984 no precedente Nix v. Williams ${ }^{489}$, um caso absolutamente específico e que, como visto anteriormente, apenas em razão de suas particularidades (tais como a busca feita por cerca de duzentos voluntários, o clima frio da região etc.) é que a descoberta do corpo e os elementos de prova respectivos foram considerados admissíveis nos autos do processo, visto que, naquele caso específico era possível considerar que seriam inevitavelmente descobertos em um curto intervalo de tempo e nas mesmas condições em que o foram ${ }^{490}$.

Ressalte-se, ainda, que conforme constou daquele julgamento inaugural, apenas seria possível considerar o elemento de prova ilícito se a outra linha de investigação que se considera levaria inevitavelmente ao mesmo elemento de prova já estivesse em curso, quando da prática da ilicitude.

Entretanto a Reforma Processual Penal de 2008, sem se dar conta da impropriedade de inserir em lei uma ressalva verdadeiramente excepcional e casuística, acabou por trazer para o Código de Processo Penal brasileiro tal exceção à ilicitude por derivação, de maneira oblíqua e sem boa técnica.

De fato o parágrafo primeiro do artigo 157 do CPP quando trata das ressalvas à teoria da ilicitude por derivação não menciona a descoberta inevitável. Entretanto, ao pretender definir fonte independente o legislador infraconstitucional acabou por trazer para o Código um conceito que se aproxima da descoberta inevitável: “aquela que por si só, seguindo

\footnotetext{
${ }^{487}$ KAMISAR, Yale; LAFAVE, Wayne; ISRAEL, Jerold. Modern Criminal Procedure: Cases Comments and Questions, p. 821.

${ }_{488}$ KAMISAR, Yale; LAFAVE, Wayne; ISRAEL, Jerold. Modern Criminal Procedure: Cases Comments and Questions, p. 808.

${ }_{489}$ O precedente encontra-se já retratado no trabalho no tópico 2.1 .

${ }^{490}$ KAMISAR, Yale; LAFAVE, Wayne; ISRAEL, Jerold. Modern Criminal Procedure: Cases Comments and Questions, p. 818.
} 
os trâmites típicos e de praxe, próprios da investigação ou instrução criminal, seria capaz de conduzir ao fato objeto da prova". 491

Ora, como já mencionado, no caso de aplicação da teoria da fonte independente é preciso que houvesse uma fonte autônoma e anterior (ou ao menos concomitante) ao momento em que se deu a ilicitude, e que esta fonte de provas tivesse conduzido o investigador ao mesmo elemento de prova viciado por derivação. Isto é, quando da prática da ilegalidade pelo indivíduo que obtém a prova é preciso que a fonte de prova autônoma fosse já uma realidade concreta e empiricamente verificável. Na descoberta inevitável, por sua vez, ainda que seja necessário que a linha de investigação paralela que levaria inevitavelmente ao mesmo elemento de prova obtido ilicitamente estivesse já em curso quando da prática da ilegalidade, o encontro da nova fonte de prova configura-se tão somente em uma probabilidade $^{492}$.

Assim a hipótese aventada no parágrafo segundo do artigo 157 do Código de Processo Penal por certo não trata de fonte independente.

É nesse sentido também o entendimento de Andrey Borges de Mendonça. Segundo o autor a limitação da descoberta inevitável foi também admitida pelo artigo 157, § $2^{\circ}$, do CPP, pois embora o legislador tenha se valido da expressão "fonte independente", trata na verdade da descoberta inevitável ${ }^{493}$.

Conforme explica Nereu José Giacomolli "na realidade, quando se afasta o nexo causal, se está falando de fonte independente, de uma origem lícita e diferenciada, mas quando se fala em descoberta inevitável, se está mantendo a derivação, a ilicitude anterior contaminante da prova. Esta é admitida pelo CPP porque, através de outros meios lícitos se chegaria ao mesmo resultado, de forma inevitável". 494

Nas palavras de Antonio Magalhães Gomes Filho "os fundamentos dessas duas exceções à contaminação da prova são evidentemente diversos: na hipótese de haver uma fonte independente, a prova derivada tem concretamente duas origens - uma ilícita e outra lícita -, de tal modo que, ainda que suprimida a fonte ilegal, o dado probatório trazido ao

\footnotetext{
${ }^{491}$ GOMES FILHO, Antonio Magalhães. Provas Lei 11.690, de 09.06.2008, p. 269.

${ }^{492}$ KAMISAR, Yale; LAFAVE, Wayne; ISRAEL, Jerold. Modern Criminal Procedure: Cases Comments and Questions, p. 821.

${ }^{493}$ MENDONÇA, Andrey Borges de. Nova Reforma do Código de Processo Penal, p. 170.

${ }^{494}$ GIACOMOLLI, Nereu José. Reformas do Processo Penal: Considerações críticas, p. 47.
} 
processo subsiste e, por isso, pode ser validamente utilizado. Já na situação de descoberta inevitável, a prova tem efetivamente uma origem ilícita, mas as circunstâncias do caso permitem considerar, por hipótese, que seria inevitavelmente obtida, mesmo se suprimida a fonte ilícita". 495

Tal dispositivo trata de mecanismos investigativos e de instrução probatória que seriam capazes de conduzir ao "fato objeto de prova" mesmo sem a conduta ilegal praticada - fazendo alusão, na verdade, à fonte de prova. Assim, referido dispositivo está a indicar que, se pelo estágio da investigação desenvolvida no caso, com alto grau de probabilidade for possível afirmar que a prova ilícita seria igualmente obtida por meios idôneos, esta poderá ser utilizada ${ }^{496}$.

Logo, o parágrafo segundo do artigo 157 do CPP acaba por trazer nova hipótese legal de não aplicação da ilicitude por derivação, consistindo em verdadeira exceção à regra da inadmissibilidade das provas ilícitas por derivação.

Ressalte-se ademais, que a descoberta inevitável não se confunde com a mera possibilidade de que a prova obtida de forma ilícita fosse obtida de forma legal, com a correção do vício ocorrido no caso concreto, pois, de outro modo, restaria ainda mais ampla a já vastíssima previsão legal.

Em outras palavras, na hipótese em que se verifica alguma ilegalidade na obtenção da prova, porém essa ilicitude poderia ter sido sanada no caso concreto de forma simples, bastando para tanto que fosse observado o ordenamento, a prova ilícita não poderá ser admitida nos autos do processo ${ }^{497}$.

Para facilitar o entendimento e a distinção das situações, um exemplo poderia ser a obtenção de autorização judicial antes da invasão de um domicílio para a realização de busca e apreensão de dado objeto, relacionado a um crime. Ora o objeto apreendido não será considerado uma fonte lícita de prova e as informações dele advindas serão inadmissíveis nos autos do processo, pois fruto de uma prova ilícita (invasão de domicílio sem autorização judicial).

\footnotetext{
${ }^{495}$ GOMES FILHO, Antonio Magalhães. Provas Lei 11.690, de 09.06.2008, p. 268.

${ }^{496}$ VIDAL, Hélvio Simões. Provas ilícitas e a extensão dos seus efeitos. De Jur: Revista Jurídica do Ministério Público de Minas Gerais, Belo Horizonte, n. 11, jul./dez. 2008, p. 212.

${ }^{497}$ Isso para aqueles que consideram que a descoberta inevitável é constitucional e poderia ensejar a admissão, nos autos do processo, de elementos de prova viciados pela ilicitude.
} 
Não há que se falar, no caso hipoteticamente apresentado, que o objeto em questão seria inevitavelmente descoberto se a autorização para a busca e apreensão fosse concedida, pois tal argumento acabaria por legitimar qualquer obtenção de prova ilícita, pois certo é que a ilicitude sempre poderia ser evitada ${ }^{498}$.

Em verdade, trata-se de solução contrária à preconizada pelo sistema germânico a partir da adoção da chamada "doutrina dos cursos causais hipotéticos", desenvolvida pelo Tribunal Superior daquele país ${ }^{499}$.

De fato, para os que aceitam a exceção da descoberta inevitável, deve se demonstrar, no caso concreto, de forma cristalina e evidente que o elemento de prova obtido de forma ilícita teria sido inevitavelmente descoberto por outro meio de obtenção de provas já em curso. Não basta para tanto alegar que, não fosse a ilicitude praticada, o referido elemento de prova seria admissível nos autos do processo.

Segundo Nereu José Giacomolli ${ }^{500}$, para que a prova derivada da ilícita seja admitida nos autos com base na teoria da descoberta inevitável é preciso que se verifique no caso concreto, em razão das circunstâncias fáticas demonstradas, a alta probabilidade do curso causal hipotético se concretizar no plano da realidade. Ou seja, há de se exigir um considerável grau de probabilidade de descoberta da prova, demonstrado de forma concreta nos autos do processo.

Portanto, conforme preleciona o autor é preciso indagar se diante do caso concreto seria possível chegar à prova derivada da ilícita através de outra fonte de prova. Em caso afirmativo será ainda necessário questionar se a descoberta da nova fonte de prova, que conduziria aos mesmos elementos de prova viciados, seria obtida naquele caso concreto de forma inevitável tendo em vista "os trâmites típicos e de praxe, próprios da investigação ou instrução criminal”. Assim, somente após terem sido transpostas todas as referidas etapas, a prova ilícita poderia ser admitida nos autos do processo com base na descoberta inevitável.

\footnotetext{
${ }^{498}$ Nesse sentido: FAINZILBER, Fernando. Prova Penal - Banimento Constitucional das Provas Ilícitas (CF, Artigo $5^{\circ}$, LVI) - Ilicitude (Originária e por Derivação) - Inadmissibilidade. Revista IOB de Direito Penal e Processual Penal, Porto Alegre, ano VIII, n. 48, fev./mar. 2008, p. 116. Destaca o autor: "A forma pela qual se chegou à prova é o que determina se está estará maculada ou não com a ilicitude daquela prova ilícita antecedente. Assim, ainda que houvesse outros inúmeros meios lícitos para alcançar determinada evidência, se, no caso concreto, esta foi alcançada em decorrência de prova ilícita, resta impregnada de ilicitude e não mais poderá ser aceita".

${ }^{499}$ Conforme mencionado no item 2.2 do trabalho.

${ }^{500}$ Reformas do Processo Penal: Considerações críticas, p. 47.
} 
Para Andrey Borges de Mendonça ${ }^{501}$ apenas com base em fatos históricos comprovados nos autos do processo e não fundados em meras especulações será possível concluir pela inevitabilidade ou não da descoberta. Não basta o juízo do possível, sendo imprescindível a realização de um juízo de probabilidade fundado em elementos concretos.

De qualquer forma, ainda que sejam seguidos os passos elencados pela doutrina, a aceitação de tal exceção é controversa.

Destarte, o instituto excepcional não fica alheio a críticas, diante da insegurança existente em serem admitidas provas ilícitas nos autos do processo em infração ao quanto previsto no artigo $5^{\circ}$, inciso LVI da CF, com base em meras "hipóteses, suposições, conjecturas e não em fatos provados". 502

Ademais a adoção da teoria da descoberta inevitável pode acabar por legitimar a obtenção de fontes de provas ilícitas que poderiam no caso concreto perfeitamente terem sido obtidas conforme a lei, terminando por reduzir a magnitude das garantias processuais penais.

De acordo com Marcelo Lopes Barroso o referido parágrafo além de afrontar o quanto estabelecido no artigo $5^{\circ}$, inciso LVI da Constituição Federal, traz insegurança jurídica ao permitir que o aplicador da lei atue como "autêntico futurólogo". Nas palavras do autor: "o legislador, ao permitir a utilização de uma prova ilícita por derivação, excedeu os limites fincados à sua tarefa, restringindo indevidamente uma garantia individual e estimulando a prática de arbitrariedades por parte dos agentes estatais". 503

Para Nereu José Giacomolli as hipóteses trazidas pela nova redação do artigo 157 do CPP advindas do processo penal norte-americano são incompatíveis com o sistema brasileiro. Segundo o autor tais excludentes da ilicitude da prova "servirão de canais à contaminação de um processo penal republicano, ético, com todas as garantias legais ${ }^{504 \text {,. }}$

Conforme Aury Lopes Júnior "como construção teórica, a tese da fonte independente (e também do encontro inevitável) é bastante clara e lógica, mas revela-se perversa quando depende da casuística e da subjetividade do julgador, na medida em que

\footnotetext{
${ }^{501}$ Nova Reforma do Código de Processo Penal, p. 170-171.

${ }^{502}$ GÓMEZ COLOMER, Juan Luis. La evolución de las teorías sobre la prueba. In: Proceso Penal. Valência: Tirant lo Blanch, 2008, p. 124. (Org.). Prueba y

${ }_{503}$ BARROSO, Marcelo Lopes. Reformas no Processo Penal, p. 105.

${ }^{504}$ GIACOMOLLI, Nereu José. Reformas do Processo Penal: Considerações críticas, p. 49.
} 
recorre a conceitos vagos e imprecisos (como é a própria discussão em torno do nexo causal)". 505

Segundo Andrey Borges de Mendonça ${ }^{506}$ é preciso fazer uma interpretação conforme do artigo 157, $\S 2^{\circ}$ do CPP, entendendo que deverão ser colacionados na análise do caso sub judice fatos concretos a indicar a probabilidade de que os mesmos elementos de prova seriam obtidos de forma inevitável. Ainda conforme o mesmo autor uma interpretação literal do dispositivo legal acabaria por ampliar em demasiado à admissibilidade das provas ilícitas por derivação nos autos do processo, ensejando inconstitucionalidades.

Antonio Magalhães Gomes Filho adota posicionamento mais radical em relação ao artigo 157, $\S 2^{\circ}$ do CPP. Segundo o autor "são as circunstâncias especiais do caso concreto (...) que permitem considerar que a prova seria inevitavelmente obtida, mesmo se suprimida a fonte ilícita. Ao contrário disso, o texto legislativo examinado permite que se suponha sempre a possibilidade de obtenção da prova derivada por meios legais, o que esvazia, por completo, o sentido da garantia. Em resumo, como está redigido, o texto do art. $157, \S 2^{\circ}$, é inconstitucional ${ }^{507}$,".

É este também o entendimento adotado no presente trabalho.

$\mathrm{O}$ artigo $157, \S 2^{\circ}$ do CPP insere no ordenamento brasileiro uma verdadeira exceção à ilicitude por derivação e, em consequiência, ao quanto disposto no artigo $5^{\circ}$, inciso LVI da Constituição Federal, ferindo a regra constitucional da inadmissibilidade das provas obtidas por meios ilícitos nos autos dos processos, na medida em que a restrição imposta é desproporcional.

A redação conferida ao dispositivo, a pretexto de definir fonte independente, insere na legislação o conceito de descoberta inevitável, fazendo-o de forma por demais excessiva: "aquela que por si só, seguindo os trâmites típicos e de praxe, próprios da investigação ou instrução criminal, seria capaz de conduzir ao fato objeto da prova".

Assim, ainda que se considere ser a adoção da descoberta inevitável um meio adequado à descoberta da verdade e à efetivação do valor segurança pública, tal medida, conforme prevista no $\S 2^{\circ}$ do artigo 157 do CPP, dificilmente será considerada necessária e

\footnotetext{
505 JÚNIOR, Aury Lopes. Direito Processual Penal e sua Conformidade Constitucional. v. I, p. 594.

${ }^{506}$ Nova Reforma do Código de Processo Penal, p. 171.

${ }^{507}$ GOMES FILHO, Antonio Magalhães. Provas Lei 11.690, de 09.06.2008, p. 269-270.
} 
mesmo que o seja, certamente não passará pelo exame da proporcionalidade em sentido estrito, por ser excessivamente restritiva do direito fundamental em comento.

De fato, a nova redação conferida ao artigo $157, \S 2^{\circ}$, do CPP termina por infringir os limites de proteção constitucionalmente definidos, ao prever restrições desproporcionais à referida regra constitucional.

Em outras palavras, se a doutrina da descoberta inevitável for aplicada conforme foi prevista pela Lei $n^{o} 11.690 / 08$, poderá tornar a exceção em regra, destituindo de qualquer eficácia a vedação constitucional às provas ilícitas nos autos do processo. É que no referido dispositivo não se exige sequer que o método investigativo legal e alternativo estivesse já em curso quando da prática da ilegalidade. Assim, interessados de má-fé poderiam praticar a ilegalidade na colheita de prova e após ser esta obtida argumentar pela admissão da fonte de prova ilícita, alegando que seria inevitavelmente descoberta valendo-se de meio de obtenção de provas legal sequer em curso.

Ademais, por ensejar um juízo de probabilidade do aplicador da lei, a teoria da descoberta inevitável exige do intérprete uma análise completa e detida da situação concreta, não podendo ser generalizada, como o foi.

Assim, por ser uma medida excessivamente restritiva do direito fundamental à prova lícita, a adoção da descoberta inevitável revela-se desproporcional em sentido estrito, tornando-se, portanto, inconstitucional.

De modo que, a despeito de integrar formalmente o ordenamento pátrio, a melhor solução de interpretação para o caso está em considerar o $§ 2^{\circ}$ do artigo 157 do Código de Processo Penal inconstitucional, devendo ser assim declarado pelo Judiciário quando levada a questão a sua análise.

\subsection{Projeto de Novo Código de Processo Penal e as provas ilícitas por derivação}

A proposta de redação conferida ao Projeto de Novo Código de Processo Penal alberga expressamente a questão da ilicitude por derivação ao falar, no caput do artigo 164 do 
CPP sugerido que "são inadmissíveis as provas obtidas, direta ou indiretamente, por meios ilícitos".

Essa previsão, que já estava contida no parágrafo primeiro do artigo 157 do CPP vigente mostra-se bastante salutar ao garantir a previsão expressa da inadmissibilidade nos autos do processo das provas ilicitamente derivadas.

Por outro lado, o dispositivo sugerido não trata de nenhuma possível mitigação à regra da inadmissibilidade das provas derivadas das originalmente ilícitas, deixando ao Judiciário a análise do caso concreto. Essa opção legislativa mostra-se louvável, vindo de fato a corrigir os erros incorridos pelo Congresso Nacional com a edição da Lei $n^{\circ}$ 11.690/08, conforme considerações anteriormente feitas.

Nos dizeres de Antonio Magalhães Gomes Filho, “a preocupação do Projeto foi a de não se afastar da previsão constitucional do art. $5^{\circ}$, LVI, limitando-se a incluir referência expressa, no caput, à prova ilícita por derivação". 508

O parágrafo único do artigo 164 sugerido no Projeto de Novo Código versa sobre a questão do desentranhamento da prova ilícita e seu arquivamento sigiloso, conforme já destacado no item 3.3.2 do trabalho.

Cabe novamente salientar que o Projeto de Novo Código de Processo Penal, em que pese seja entendido como um avanço no tratamento dispensado à questão das provas ilícitas, e em especial em relação as provas ilícitas por derivação no país, encontra-se ainda em trâmite no Congresso Nacional, podendo ser emendado pela Câmara dos Deputados no que se refere ao tema e, ao final sequer ser aprovado, razão pela qual não será alongada a discussão sobre esse ponto.

${ }^{508}$ GOMES FILHO, Antonio Magalhães. A inadmissibilidade das provas ilícitas no processo penal brasileiro, p. 410. 


\section{CONCLUSÕES}

Serão apresentadas, de forma resumida as conclusões extraídas do presente trabalho.

Conforme mencionado há íntima e necessária relação entre busca da verdade, processo penal e o direito à prova.

O processo penal é o meio necessário à aplicação da lei penal.

Para a correta aplicação da lei penal ao caso é preciso bem conhecê-lo, o que é feito pelo magistrado a partir da análise das provas inseridas nos autos. As provas buscam reproduzir a veracidade dos fatos alegados em juízo pelas partes.

A verdade é una, não comportando adjetivações como real ou formal.

A verdade é também inatingível. Entretanto isso não impede, ao revés recomenda sua busca.

A busca da verdade legitima o sistema processual penal, enquanto visa trazer para o processo Justiça para as decisões. Assim o que importa para o processo é a verdade processual, ou seja, a verdade atingível no curso do processo, respeitadas as limitações naturais impostas à sua busca.

É a partir do exercício do direito à prova que as partes fazem inserir nos autos do processo comprovações do quanto alegado, com vistas a influenciar na convicção judicial e assim obter uma decisão favorável.

Entretanto o direito à prova, como qualquer outro direito não é absoluto, encontrando limites constitucionais e legais ao seu exercício.

Dentre as limitações probatórias, importante vedação está contida no artigo $5^{\circ}$, inciso LVI, da Constituição Federal ao determinar a inadmissibilidade das provas obtidas por meios ilícitos nos autos do processo.

A Constituição Federal não estabelece o que sejam provas obtidas por meios ilícitos. 
Conforme definição doutrinária desenvolvida por Pietro Nuvolone, prevalente no país, as provas ilícitas juntamente com as provas ilegítimas seriam espécies do gênero provas ilegais, também chamadas de provas vedadas ou proibidas.

A prova seria considerada ilegal quando sua obtenção resultasse em uma violação de normas legais ou de princípios gerais do ordenamento, de natureza processual ou material. A prova seria considerada ilegítima quando contrariasse uma lei processual. Quando a proibição fosse de natureza material a prova seria ilícita.

Prova ilícita portanto seria aquela obtida em infração a normas legais ou princípios gerais do ordenamento de natureza material.

No Brasil, ao ser considerado ilícito, o elemento de prova não será admissível nos autos do processo e caso dele conste, por equívoco, deverá ser desentranhado e desconsiderado.

Os Estados Unidos são o berço da teoria acerca das exclusionary rules.

A fim de desestimular a conduta de policiais que no exercício da atividade de investigação praticavam atos ofensivos a direitos constitucionais, além de excluir dos autos meios de prova pouco confiáveis, bem como resguardar direitos fundamentais, a Suprema Corte Norte-Americana desenvolveu, com base em seus precedentes judiciais, regras determinando a exclusão dos autos do processo de provas obtidas com violação às Emendas Constitucionais de números IV, V, VI e XIV.

A ilicitude por derivação, também chamada de teoria dos frutos da árvore envenenada nasceu também naquele país, na análise do caso Silverthorne Lumber Co. v. United States, pela Corte Suprema, em 1920.

De acordo com tal formulação as provas aparentemente lícitas que derivarem, direta ou indiretamente, de prova obtida por meios ilícitos serão consideradas ilícitas por derivação e, portanto inadmissíveis. Caso constem já dos autos do processo deverão ser excluídas.

Foram também desenvolvidas pela Corte Máxima dos EUA as seguintes mitigações a fruits of the poisonous tree doctrine: a independent source limitation (exceção da fonte independente), a attenuated connection doctrine (exceção do nexo causal atenuado) e a inevitable discovery exception (exceção da descoberta inevitável), posteriormente incorporadas, em alguma medida, pelo Código de Processo Penal brasileiro de 1941. 
Também da Alemanha, Portugal, Espanha e Itália derivam importantes contribuições para o tratamento da prova ilícita no Brasil.

Internamente, desde agosto de 2008, além da disposição constitucional sobre a prova ilícita há também regramento para o tema no artigo 157 do Código de Processo Penal.

$\mathrm{O}$ artigo $5^{\circ}$, inciso LVI da Constituição Federal se constitui em uma regra constitucional proibitiva, impondo uma obrigação de não-fazer aos sujeitos do processo, sendo certo que independe de norma integrativa para ser aplicável.

No Brasil, a inadmissibilidade das provas obtidas por meios ilícitos vale para qualquer processo judicial, administrativo e até mesmo em sede de inquérito policial. Ademais, pouco importa se a prova foi obtida ilicitamente por particulares ou agentes estatais, a conseqüência será a mesma: a inadmissibilidade nos autos.

A proporcionalidade, meio eficaz para a solução de colisão de direitos fundamentais, tem natureza de regra jurídica e pode ser aplicada em matéria de ilicitude probatória. A partir da análise de suas três sub-regras (nessa ordem): adequação, necessidade e proporcionalidade em sentido estrito, o intérprete constatará qual direito fundamental deve prevalecer no caso concreto. Predomina o entendimento de que a "prova ilícita pro reo" é perfeitamente aplicável. Já a utilização da proporcionalidade para fundamentar o uso de prova ilícita em favor da acusação deve ser rechaçada, pois os valores liberdade e dignidade humana tendem a ser considerados mais relevantes do que a punição a qualquer custo.

O artigo 157 caput do CPP prevê um conceito legal para provas ilícitas como àquelas obtidas em violação a normas constitucionais ou legais. Referido conceito, contrariando a definição de Pietro Nuvolone, não determina se as normas legais infringidas teriam caráter de direito material ou processual; tampouco aduz se as normas constitucionais seriam de natureza fundamental ou não.

A despeito da tormentosa discussão acerca do tema, entende-se que a sistemática até então vigente permanece válida, com a distinção entre provas ilícitas e provas ilegítimas, vigorando para estas últimas o regime das nulidades e para àquelas a inadmissibilidade.

No que tange a conceituação de prova ilícita, alinhando-se à posição doutrinária mais moderna, define-se, no trabalho, provas ilícitas como àquelas obtidas em ofensa a direitos fundamentais, notadamente com a prática de condutas tipificadas como crimes pela 
legislação penal. Tal conceituação é defendida mesmo em face da disposição legal contida no caput do artigo 157 do CPP, a partir da combinação das regras de interpretação normativas consistentes nos métodos histórico, lógico e sistemático.

Por sua vez, provas ilegítimas serão aquelas produzidas com infração a dispositivos processuais.

A prova declarada ilícita só poderá ser inutilizada após o trânsito em julgado dessa decisão. Por falta de previsão legal, entende-se que a referida preclusão só ocorrerá com o trânsito em julgado da sentença.

Nas hipóteses em que a prova ilícita se constitua na própria materialidade dos crimes perpetrados para que ela fosse obtida, a prova deverá ser arquivada sigilosamente em cartório e não destruída. O mesmo procedimento poderá ser adotado, a pedido da defesa, no caso de "prova ilícita pro reo". É o que propugna o Projeto de Novo Código de Processo Penal para todos os casos de provas consideradas ilícitas.

A despeito do veto presidencial ao $\S 4^{\circ}$ do artigo 157 do CPP, entende-se que, a fim de garantir que a prova ilícita não influencie no julgamento da causa, além de ser desentranhada dos autos, deverá ser adotado em relação ao Magistrado que dela tomou conhecimento procedimento similar aos casos de impedimento ou suspeição judicial.

A vedação às provas ilícitas por derivação não vem prevista de forma expressa na Constituição Federal, contudo pode-se afirmar que possui sede constitucional implícita, com base em interpretação lógica e sistemática do artigo $5^{\circ}$, inciso LVI da CF.

A Constituição não traz qualquer ressalva à regra da inadmissibilidade das provas ilícitas nos autos do processo.

Uma vez previsto no capítulo que trata dos direitos e deveres individuais e coletivos, no título dos direitos e garantias fundamentais, constitui-se o direito à inadmissibilidade das provas ilícitas em cláusula pétrea, com fulcro no quanto previsto no artigo $60, \S 4^{\circ}$, inciso IV, da CF.

Entretanto, a existência de expressa proibição à edição de emendas constitucionais que restrinjam o alcance de proteção da vedação à ilicitude probatória, não implica a impossibilidade de que o direito à prova lícita seja regulamentado por lei, desde que a referida lei restritiva tenha o intuito de compatibilizar o exercício por seus titulares, de direitos fundamentais colidentes e que seja proporcional. 
Não é o que ocorre, contudo, com a Lei no 11.690/08, que traz para o Código de Processo Penal mitigações desproporcionais à regra da ilicitude derivada.

Prevê o $\S 1^{\circ}$ do artigo 157 do CPP serem "inadmissíveis as provas derivadas das ilícitas, salvo quando não evidenciado o nexo de causalidade entre umas e outras, ou quando as derivadas puderem ser obtidas por uma fonte independente das primeiras”. O $\S 2^{\circ}$ do mesmo dispositivo a pretexto de definir fonte independente insere no Código a exceção à ilicitude por derivação da descoberta inevitável.

A teoria da fonte independente apregoa que um elemento de prova não será considerado viciado, e será, portanto admissível nos autos do processo, se for obtido por uma fonte de prova diversa daquela em que se tenha configurado a ilicitude, desde que essa fonte seja anterior ou concomitante à ilegalidade praticada. Não há nesse caso verdadeira exceção à prova ilícita, mas ausência de nexo causal entre a ilicitude e a prova obtida por uma fonte independente, não se configurando, portanto, qualquer ofensa ao quanto disposto no artigo $5^{\circ}$, inciso LVI, da Constituição Federal.

Também no caso de inexistência de nexo causal entre a prova ilícita e a prova secundária não há que se falar em exceção à regra da ilicitude derivada, pois, constata-se, na verdade, a ausência do pressuposto necessário à aplicação da regra.

A despeito da existência de posicionamento em sentido contrário, entende-se não ser possível vislumbrar nessa menção legislativa à "não evidenciação do nexo de causalidade entre as provas ilícitas e as provas secundárias" uma inclinação para a mitigação à ilicitude por derivação da attenuated connection doctrine.

Segundo esta doutrina os eventos ocorridos no bojo do caso concreto podem atenuar de forma considerável e até mesmo fazer cessar a relação de causalidade existente entre a prova ilícita e as provas posteriores, tornando estas últimas admissíveis.

Considera-se que referida exceção não foi incorporada pela legislação brasileira, tendo em vista tratar-se de restrição desproporcional em relação à regra que veda a admissibilidade das provas obtidas por meios ilícitos nos autos do processo.

A teoria da descoberta inevitável, por sua vez, dispõe que na análise do fato probando podem ser considerados elementos de prova advindos de provas obtidas por meios ilícitos, caso se entenda que esses elementos de prova seriam inevitavelmente descobertos em atuações conforme a lei. Trata-se de verdadeira exceção à teoria da ilicitude por derivação, em 
afronta ao quanto previsto constitucionalmente, uma vez que se constitui em restrição excessiva do direito fundamental à prova lícita e, portanto, desproporcional.

Desse modo, conclui-se que as hipóteses trazidas pelo $\S 1^{\circ}$ do artigo 157 do CPP, quais sejam: a fonte independente e a inexistência de nexo causal entre as provas, em que pese fossem dispensáveis, não trarão grandes problemas ao intérprete. Este apenas deverá, em relação à última hipótese, determinar, para além da dúvida, a existência ou não de nexo causal entre a prova ilícita e as demais provas constantes dos autos. Em relação a teoria do nexo causal atenuado entende-se não ter sido admitida pelo ordenamento brasileiro.

Já o $§ 2^{\circ}$ do mesmo dispositivo encontra-se em flagrante inconstitucionalidade devendo assim ser declarado pelo Judiciário.

De fato, a exceção da descoberta inevitável imposta por lei à regra constitucional da ilicitude por derivação não pode ser aceita, uma vez que se trata de restrição não justificável constitucionalmente, na medida em que excessivamente restritiva do direito à prova lícita.

De qualquer modo, os hard cases em matéria de ilicitude probatória quando verificados no caso concreto deverão ser analisados em suas especificidades e propostas soluções particulares e constitucionalmente justificáveis para o caso a caso, como com a aplicação do sopesamento e da regra da proporcionalidade.

Por fim, cumpre destacar ainda que o Projeto de Novo Código de Processo Penal, aprovado em dezembro de 2010 pelo Plenário do Senado, prevê no caput do artigo 164 sugerido serem inadmissíveis as provas obtidas, direta ou indiretamente, por meios ilícitos.

Essa redação traz consideráveis avanços no tratamento dispensado à questão das provas ilícitas, no sentido de acabar com um conceito legal para a ilicitude probatória e, em especial em relação às provas ilícitas por derivação, ao prever sua inadmissibilidade de forma expressa, sem mitigar tal regra.

Entretanto o referido Projeto de Lei encontra-se ainda em trâmite no Congresso Nacional, podendo ser emendado pela Câmara dos Deputados e sequer vir a ser aprovado. 


\section{BIBLIOGRAFIA}

ALEXY, Robert. Teoria dos Direitos Fundamentais. Tradução de Virgílio Afonso da Silva. São Paulo: Editora Malheiros, 2008.

AMBOS, Kai; CHOUKR, Fauzi Hassan. A Reforma do Processo Penal no Brasil e na América Latina. São Paulo: Editora Método, 2001.

ANDRADE, Manuel da Costa. Sobre as Proibições de Prova em Processo Penal. Coimbra: Coimbra Editora, 2006.

ARAÚJO, José Osterno Campos de. Verdade Processual Penal: Limitações à Prova. Curitiba: ABDR, 2005.

ASHWORTH, Andrew. The Criminal Process: An Evaluative Study, 2nd ed. New York: Oxford University Press, 1998.

ÁVILA, Humberto. Teoria dos Princípios: da definição à aplicação dos princípios jurídicos. 11. ed. rev. São Paulo: Editora Malheiros, 2010.

ÁVILA, Thiago André Pierobom. Provas ilícitas e Proporcionalidade. Rio de Janeiro: Editora Lumen Juris, 2007.

AVOLIO, Luiz Francisco Torquato. Provas ilícitas: Interceptações telefônicas, ambientais e gravações clandestinas. 3. ed. São Paulo: Editora Revista dos Tribunais, 2003.

BADARÓ, Gustavo Henrique Righi Ivahy. Ônus da Prova no Processo Penal. São Paulo: Editora Revista dos Tribunais, 2003. 
. Provas típicas e provas anômalas: inadmissibilidade da substituição da prova testemunhal pela juntada de declarações escritas de quem poderia ser testemunha. In: YARSHELL, Flávio Luiz; MORAES, Maurício Zanoide de (Orgs.). Estudos em Homenagem à Professora Ada Pellegrini Grinover. São Paulo: Editora DPJ, 2005.

BARROS, Flaviane de Magalhães. (Re)forma do Processo Penal: Comentários críticos dos artigos modificados pelas Leis n. 11.690/08, n. 11.719/08 e n. 11.900/09. 2. ed. Belo Horizonte: Del Rey, 2009.

BARROS, Marco Antonio de. A busca da verdade no Processo Penal. São Paulo: Editora Revista dos Tribunais, 2002.

BARROSO, Marcelo Lopes. Reformas no Processo Penal. Fortaleza: Editora Realce, 2009.

BARROSO Luís Roberto; BARCELLOS Ana Paula de. A nova interpretação constitucional dos princípios. In: LEITE, George Salomão (Org.). Dos Princípios Constitucionais: Considerações em torno das normas principiológicas da Constituição. São Paulo: Malheiros, 2003.

BELING, Ernst; AMBOS, Kai; GUERRERO, Óscar Julián. Las prohibiciones probatorias. Bogotá: Editorial Temis S.A., 2009.

BLOOM, Robert; BRODIN, Mark. Criminal Procedure: Examples and Explanatios. 4th ed. New York: Aspen Publishers, 2004.

BONAVIDES, Paulo. Curso de Direito Constitucional. 19. ed. São Paulo: Editora Malheiros, 2006.

CANOTILHO, José Joaquim Gomes. Direito Constitucional. 6. ed. Coimbra: Almedina, 1993.

CARNAÚBA, Maria Cecília Pontes. Prova ilícita. São Paulo: Editora Saraiva, 2000. 
CARVALHO, Ricardo Cintra Torres de. A inadmissibilidade da prova ilícita em processo penal: um estudo comparativo das posições brasileira e norte-americana. Revista Brasileira de Ciências Criminais, São Paulo, v. 3, n. 12, out./dez. 1995.

CASTRILLO, Eduardo de Urbano; MORATO, Miguel Angel Torres. La Prueba Ilícita Penal: Estudio Jurisprudencial. 2. ed. Pamplona: Editora Aranzadi, 2000.

CASTRO, Raimundo Amorim de. Provas Ilícitas e o Sigilo das Comunicações Telefônicas. Curitiba: Editora Juruá, 2008.

CHIMENTI, Francesco. O processo penal e a verdade material: teoria da prova. Rio de Janeiro: Forense, 1995.

CHINELATO, João Marcelo Torres. O princípio da proporcionalidade proibindo a omissão Estatal: por uma hermenêtica comprometida com a integridade dos direitos fundamentais. Disponível em: 〈http://jus2.uol.com.br/doutrina/texto.asp?id=9889>. Acesso em: 18 out. 2010.

CINTRA, Antonio Carlos de Araújo; GRINOVER, Ada Pellegrini; DINAMARCO, Cândido Rangel. Teoria Geral do Processo. 20. ed. São Paulo: Editora Malheiros, 2004.

CORDERO, Franco. Tre studi sulle prove penali. Milano: Giuffrè, 1963.

COSTA JÚNIOR, Paulo José da. O direito de estar só: Tutela penal da intimidade. 4. ed. São Paulo, Editora Revista dos Tribunais, 2007.

DALLARI, Dalmo de Abreu. Elementos da teoria geral do Estado. 25. ed. São Paulo: Saraiva, 2005. 
DALIA, Andrea Antonio; FERRAIOLI, Marzia. Manuale di Diritto Processuale Penale. $4^{\mathrm{a}}$ ed. Padova: CEDAM, 2001.

DELMAS-MARTY, Mireille. Procesos Penales de Europa (Alemania, Inglaterra y País de Gales, Bélgica, Francia, Italia). Zaragoza: EDIJUS, 2000.

DEZEM, Guilherme Madeira. Tipicidade processual e provas típicas e atípicas. 2008. $182 \mathrm{f}$. Dissertação (Mestrado em Direito) - Faculdade de Direito, Universidade de São Paulo, São Paulo.

DÍEZ, Carlos Gómez-Jara. Nuevas tendencias en materia de prueba ilícita: El caso Hudson v. Michigan y el caso da la Exclusionary Rule en EE.UU. Revista de Derecho y Proceso Penal, Navarra, n. 20, 2008.

DINAMARCO, Cândido Rangel. Instituições de Direito Processual Civil. 4. ed. São Paulo: Malheiros Editores, 2004. v. I.

DEU, Teresa Armenta. La prueba ilícita (un estudio comparado). Madrid: Marcial Pons, 2009.

DWORKIN, Ronald. Levando os direitos a sério. Tradução de Nelson Boeira. São Paulo: Editora Martins Fontes, 2002.

EDWARDS, Carlos Enrique. La prueba ilegal en el proceso penal. Cordoba: Editorial Cordoba, 2000.

FAINZILBER, Fernando. Prova Penal - Banimento Constitucional das Provas Ilícitas (CF, Artigo $5^{\circ}$, LVI) - Ilicitude (Originária e por Derivação) - Inadmissibilidade. Revista IOB de Direito Penal e Processual Penal, Porto Alegre, ano VIII, n. 48, fev./mar. 2008. 
FERNANDES, Antonio Scarance. O equilíbrio na repressão ao crime organizado. In: FERNANDES, Antonio Scarance; ALMEIDA, José Raul Gavião de; MORAES, Maurício Zanoide de (Coords.). Crime Organizado Aspectos Processuais. São Paulo: Editora Revista dos Tribunais, 2009.

Processo Penal Constitucional. 6. ed. São Paulo: Revista dos Tribunais, 2010.

— Reflexões sobre as noções de eficiência e de garantismo no processo penal. In: FERNANDES, Antonio Scarance; ALMEIDA, José Raul Gavião de; MORAES Maurício Zanoide de (Coords.). Sigilo no Processo Penal: eficiência e garantismo. São Paulo: Editora Revista dos Tribunais, 2008.

FEITOZA, Denilson. Reforma Processual Penal: uma abordagem sistêmica. Niterói: Editora Impetus, 2008.

FELICIONI, Paola. Le ispezioni e le perquisizioni. Milano: Giuffrè, 2004.

FERRAJOLI, Luigi. Direito e Razão: Teoria do Garantismo Penal. 2. ed. rev. e ampl. Tradução de Ana Paula Zomer Sica (et al). São Paulo: Editora Revista dos Tribunais, 2006.

FLORIAN, Eugenio. De las pruebas penales. Bogotá: Editorial Temis, 1968. tomo I.

FRANÇA, R. Limongi. Hermenêutica Jurídica. 10. ed. rev. São Paulo: Editora dos Tribunais, 2010 .

FREITAS, Juarez. A interpretação sistemática do direito. 2. ed. rev. e ampl. São Paulo: Malheiros, 1998.

GIACOMOLli, Nereu José. Reformas do Processo Penal: Considerações críticas. Rio de Janeiro: Editora Lumen Juris, 2008. 
GOMES, Luiz Flávio. Lei 11.690/2008 e provas ilícitas: conceito e admissibilidade. Disponível em: 〈http://www.lfg.com.br〉. Acesso em: 20 jun. 2008. . Prova ilícita: direito à exclusão dos autos do processo ("exclusionary rule"). Disponível em: 〈http://www.lfg.com.br/public html/article.php?story20041008122122480p〉. Acesso em: 15 set. 2010.

GOMES, Luiz Flávio; CUNHA, Rogério Sanches; PINTO, Ronaldo Batista. Comentários às Reformas do Código de Processo Penal e da Lei de Trânsito. São Paulo: Editora Revista dos Tribunais, 2008.

GOMES FILHO, Antonio Magalhães. A inadmissibilidade das provas ilícitas no processo penal brasileiro. Revista Brasileira de Ciências Criminais, São Paulo, ano 18, n. 85, jul./ago. 2010.

A presunção de inocência e o ônus da prova em processo penal. Boletim IBCCRIM, São Paulo, n. 23, nov. 1994.

. Notas sobre a terminologia da prova (reflexos no processo penal brasileiro). In: YARSHELL, Flávio Luiz; MORAES, Maurício Zanoide de (Orgs.). Estudos em Homenagem à Professora Ada Pellegrini Grinover. São Paulo: Editora DPJ, 2005.

. Provas Lei 11.690, de 09.06.2008. In: MOURA, Maria Thereza Rocha de Assis (Coord.). As Reformas no Processo Penal: As novas Leis de 2008 e os Projetos de Reforma. São Paulo: Revista dos Tribunais, 2008.

. Sobre o direito à prova no processo penal. 1995. 195 f. Tese (Livre- docência do Departamento de Direito Processual) - Faculdade de Direito, Universidade de São Paulo, São Paulo. 
GÓMEZ COLOMER, Juan Luis. La evolución de las teorías sobre la prueba. In:

(Org.). Prueba y Proceso Penal. Valência: Tirant lo Blanch, 2008.

GONÇALVES, Manuel Lopes Maia. Código de Processo Penal: Anotado. 11. ed. Coimbra: Almedina, 1999.

GRAU, Eros Roberto. Ensaio e discurso sobre a interpretação/aplicação do direito. 4. ed. São Paulo: Malheiros, 2006.

GRINOVER, Ada Pellegrini. Liberdades Públicas e Processo Penal: as interceptações telefônicas, 2. ed. São Paulo: Editora Revista dos Tribunais, 1982.

. Provas ilícitas. Separata da Revista da Procuradoria Geral do Estado, São Paulo, n. 16, jun. 1980.

GRINOVER, Ada Pellegrini; FERNANDES, Antonio Scarance; GOMES FILHO, Antonio Magalhães. As Nulidades no Processo Penal. 10. ed. São Paulo: Revista dos Tribunais, 2007.

GUARIGLIA, Fabricio. Concepto, fin y alcance de las prohibiciones de valoración probatoria en el procedimiento penal: Una propuesta de fundamentación. Buenos Aires: Del Puerto, 2005.

. Las prohibiciones de valoración probatoria en el procedimiento penal. Jueces para la Democracia, Madrid, n. 26, jul. 1996.

GUERRA FILHO, Willis Santiago. Princípio da Proporcionalidade e Devido Processo Legal. In: SILVA, Virgílio Afonso da (Org.). Interpretação Constitucional. São Paulo: Malheiros, 2005. 
. Sobre o princípio da proporcionalidade. In: LEITE, George Salomão (Org.). Dos Princípios Constitucionais: Considerações em torno das normas principiológicas da Constituição. São Paulo: Malheiros, 2003.

HECK, Luís Afonso. Regras, princípios jurídicos e sua estrutura no pensamento de Robert Alexy. In: LEITE, George Salomão (Org.). Dos princípios constitucionais: Consideraçães em torno das normas principiológicas da Constituição. São Paulo: Malheiros, 2003.

JÚNIOR, Aury Lopes. Direito Processual Penal e sua Conformidade Constitucional. 5. ed. Rio de Janeiro: Editora Lumen Juris, 2010. v. I.

. Direito Processual Penal e sua Conformidade Constitucional. 3. ed. Rio de Janeiro: Editora Lumen Juris, 2010. v. II.

JUSTO, Ana Rita de Melo. Proibição da prova em processo penal: o agente provocador; acórdão do Supremo Tribunal de Justiça de 30 de outubro de 2002. Revista Portuguesa de Ciência Criminal, Coimbra, ano 16, n. 3, jul./set. 2006.

KAMISAR, Yale; LAFAVE, Wayne; ISRAEL, Jerold. Modern Criminal Procedure: Cases Comments and Questions. 8th ed. St. Paul: West Publishing Co, 1994.

LENZA, Pedro. Direito Constitucional Esquematizado. 12. ed. rev. atual. e ampl. São Paulo: Editora Saraiva, 2008.

MACHADO, Antônio Cláudio da Costa (Org.). Constituição Federal Interpretada: artigo por artigo, parágrafo por parágrafo. Barueri: Manole, 2010.

MALATESTA, Nicola Framarino dei. A lógica das provas em matéria criminal. Tradução de J. Alves de Sá. Campinas: Servanda Editora, 2009. 
MENDES, Gilmar Ferreira; COELHO, Inocêncio Mártires; BRANCO, Paulo Gustavo Gonet. Curso de Direito Constitucional. 4. ed. rev. e atual. São Paulo: Saraiva, 2009.

MENDES, Paulo de Sousa. O processo penal em acção. In: Questões Avulsas de Processo Penal. Lisboa: AAFDL, 2000.

MENDONÇA, Andrey Borges de. Nova Reforma do Código de Processo Penal. 2. ed. São Paulo: Editora Método, 2009.

MELLADO, José María Asencio. Prueba Prohibida y Prueba Preconstituida en el Proceso Penal. Lince: Instituto Peruano de Criminologia y Ciencias Penales, 2008.

MELLO, Fábia Amaral de Oliveira. A prova ilícita e a possibilidade de sua aplicação no processo penal. Revista da ESMAPE, Recife, v. 7, n. 15, jan./jun. 2002.

MIRABETE, Julio Fabbrini. Código de Processo Penal Interpretado. 11. ed. São Paulo: Editora Atlas, 2008.

MITTERMAIER, Karl Joseph Anton. Tratado de la prueba em materia criminal. Tradução de Primitivo González Del Alba. Buenos Aires: Hammurabi, 2006.

MORAES, Maurício Zanoide de. Presunção de Inocência no Processo Penal Brasileiro: análise de sua estrutura normativa para a elaboração legislativa e para a decisão judicial. 2008. 603 f. Tese (Livre- docência do Departamento de Direito Processual) - Faculdade de Direito, Universidade de São Paulo, São Paulo.

MORÃO, Helena. O efeito à distância das proibições de prova no Direito Processual Penal Português. Revista Portuguesa de Ciência Criminal, Coimbra, ano 16, n. 4, out./dez. 2006.

MOREIRA, José Carlos Barbosa. A Constituição e as provas ilicitamente obtidas. Revista Forense, Rio de Janeiro, v. 93, n. 337, jan./mar. 1997. 
. Comentários ao Código de Processo Civil. 8. ed. Rio de Janeiro: Editora Forense, 1999. v. V.

MOREIRA, Reinaldo Daniel. A reforma do Código de Processo Penal e a nova disciplina legislativa da prova penal. Boletim do Instituto de Ciências Penais, Belo Horizonte, ano VII, n. 91 , out. 2008 .

MOREIRA, Rômulo de Andrade. A Reforma do Código de Processo Penal. Disponível em: <http://www1.jus.com.br/DOUTRINA/texto.asp?id=2572> . Acesso em: 20 ago. 2010.

NOBILI, Massimo. Commento art. 191. In: CHIAVARIO, Mario (Org.). Commento al nuovo Codice di Procedura Penale. Torino: Utet, 1990. v. 2.

NUCCI, Guilherme de Souza. Provas no Processo Penal. São Paulo: Editora Revista dos Tribunais, 2009.

NUVOLONE, Pietro. Le prove vietate nel processo penale nei paesi di diritto latino. Rivista di Diritto Processuale, Padova, v. XXI, 1966.

OLIVEIRA, Eugênio Pacelli de. Curso de Processo Penal. 10. ed. Rio de Janeiro: Editora Lumen Juris, 2008.

PIMENTA, José da Costa. Código de Processo Penal Anotado. 2. ed. Lisboa: Rei dos Livros, 1991.

PITOMBO, Cleunice Aparecida Valentim Bastos. Processo Penal: Prova e Verdade. 2003. 209. f. Tese (Doutorado em Direito) - Faculdade de Direito, Universidade de São Paulo, São Paulo. 
PRADO, Leandro Cadenas. Provas Ilícitas: Teoria e Interpretação dos Tribunais Superiores. 2. ed. Niterói: Editora Impetus, 2009.

RAMOS, José Gualberto Garcez. Curso de Processo Penal norte-americano. São Paulo: Editora Revista dos Tribunais, 2006.

ROGALL, Klaus. Questioni fondamentali in tema di divieti probatori. L'indice penale, Padova, ano I, n. 3, set./dez. 1998.

ROXIN, Claus. Derecho procesal penal. Tradução de Gabriela Córdoba; Daniel Pastor. 25. ed. Buenos Aires: Editores del Puerto, 2000.

SANTOS, Manuel Simas; LEAL-HENRIQUES, Manuel. Código de Processo Penal Anotado. Lisboa: Rei dos Livros, 1999. v. 1.

SARLET, Ingo Wolfgang. A eficácia dos direitos fundamentais. 8. ed. rev. e atual. Porto Alegre: Editora Livraria do Advogado, 2007.

SEGADO, Carmelo Jiménez. La prueba ilícita y las reglas de desconexión de sus efectos. La Ley Penal: Revista de Derecho Penal, Procesal y Penitenciario, Madrid, ano VI, n. 58, mar. 2009.

SERRANO, Nicolas Gonzalez-Cuellar. Proporcionalidad y derechos fundamentales en el processo penal. Madrid: Colex, 1990.

SILVA, Bruno César Gonçalves da. Da prova ilicitamente obtida por particular no Processo Penal. Campinas: Editora Servanda, 2010.

SILVA, César Dario Mariano da. Provas Ilícitas. 4. ed. Rio de Janeiro: Editora Forense, 2005. 
SILVA, Ivan Luís Marques da. Reforma Processual Penal de 2008: Lei 11.719/2008 (Procedimentos Penais), Lei 11.690/2008 (Provas), Lei 11.689/2008 (Júri), Comentadas artigo por artigo. São Paulo: Editora Revista dos Tribunais, 2008.

SILVA, José Afonso da. Aplicabilidade das normas constitucionais. 7. ed. São Paulo: Malheiros, 2008.

SILVA, Virgílio Afonso da. Direitos Fundamentais: conteúdo essencial, restrições e eficácia. 2. ed. São Paulo: Malheiros, 2010.

. Interpretação Constitucional e Sincretismo Metodológico. In: (Org.). Interpretação Constitucional. São Paulo, Editora Malheiros, 2010.

SIMONS, Christian Sthefan. A prova ilícita no direito processual penal norte-americano e alemão e as influências no processo penal brasileiro. 2007. 168 f. Dissertação (Mestrado em Direito) - Faculdade de Direito, Universidade de São Paulo, São Paulo.

SOUZA, Sérgio Ricardo de. Manual da Prova Penal Constitucional: Pós Reforma de 2008 atualizado de acordo com as Leis 11.689/08 e 11.690/08. Curitiba: Juruá, 2008.

TARUFFO, Michele. Consideraciones sobre prueba y verdad. Derechos y Libertades: Revista del Instituto Bartolomé de las Casas, Madrid, ano VII, n. 11, jan./dez. 2002.

La prueba de los hechos. Tradução de Jordi Ferrer Beltrán. Madrid: Editorial Trotta, 2002.

La semplice verità: Il giudice e la construzione dei fatti. Roma: Editori Laterza, 2009.

TONINI, Paolo. A prova no processo penal italiano. Tradução de Alexandra Martins Daniela Mróz. São Paulo: Editora Revista dos Tribunais, 2002. 
TASSE, Adel El; MILÉO, Eduardo Zanoncini; PIASECKI, Patrícia Regina. O Novo Sistema de Provas no Processo Penal. Curitiba: Editora Juruá, 2008.

TORNAGHI, Hélio Bastos. Curso de Processo Penal. São Paulo: Editora Saraiva, 1991. v. I.

UBERTIS, Giulio. La prova penale: Profili giuridici ed epistemologici. Torino: UTE, 1999.

UGLOW, Steve. Issues in Evidence in English Criminal Law. Studi Senesi, Siena, v. 112, n. 1, 2000.

VALENTE, Manuel Monteiro Guedes. Processo Penal. Coimbra: Almedina, 2004. tomo I.

VALLE FILHO, Oswaldo Trigueiro do. A ilicitude da prova: teoria do testemunho de ouvir dizer. São Paulo: Editora Revista dos Tribunais, 2004.

VALLE FILHO, Oswaldo Trigueiro do (Coord.). Estudos Jurídicos Luso-Brasileiros (UNIPÊ/COIMBRA). João Pessoa: UNIPÊ Editora, 2006.

VIDAL, Hélvio Simões. Provas ilícitas e a extensão dos seus efeitos. De Jur: Revista Jurídica do Ministério Público de Minas Gerais, Belo Horizonte, n. 11, jul./dez. 2008.

ZILLI, Marcos Alexandre Coelho. A prova ilícita e o Tribunal Penal Internacional: Regras de admissibilidade. 2006. 290 f. Tese (Doutorado em Direito) - Faculdade de Direito, Universidade de São Paulo, São Paulo.

. O pomar e as pragas. Boletim IBCCRIM, São Paulo, ano 16, n. 188, jul. 2008. 


\section{OUTRAS REFERÊNCIAS}

$<$ http://supreme.justia.com/us>.

<http://www.law.cornell.edu $>$.

<http://www.boe.es> (sítio do Boletín Oficial del Estado Espanhol).

<http://www.jusbrasil.com.br>.

$<$ http://openjurist.org>.

<http://imagem.camara.gov.br/diarios.asp> (Diário da Câmara dos Deputados, Mensagem 211, de 30 mar. 2001). 